
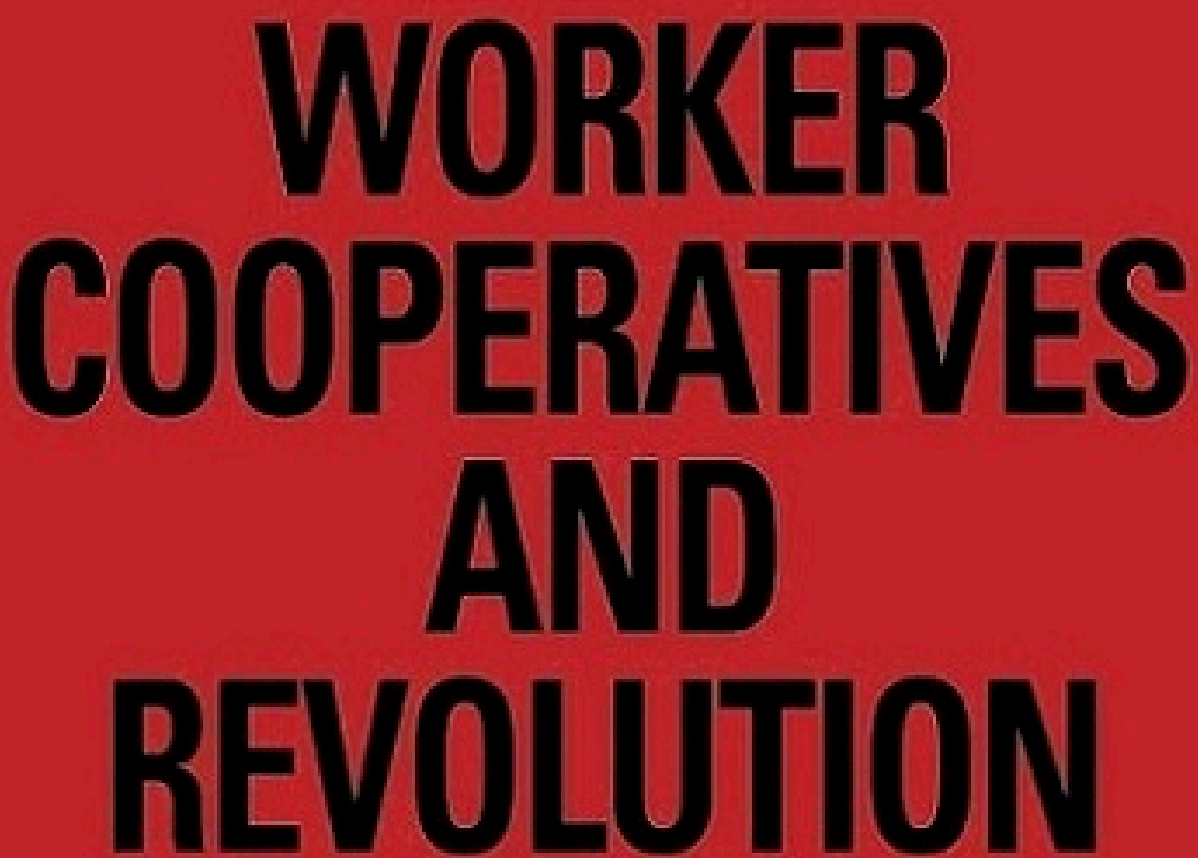

HISTORY AND POSSIBILITIES IN THE UNITED STATES

\title{
CHRIS WRIGHT
}

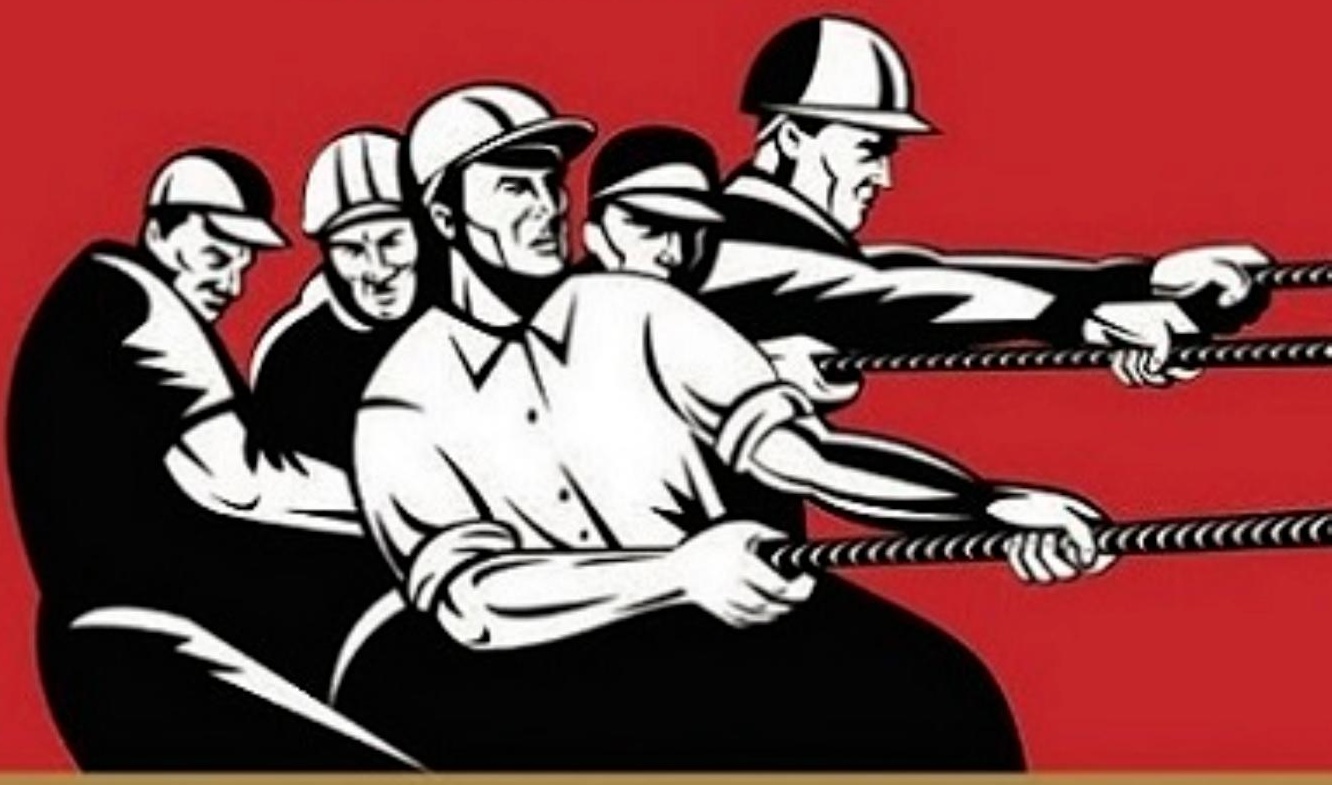




\title{
WORKER COOPERATIVES AND REVOLUTION:
}

\section{HISTORY AND POSSIBILITIES}

IN THE UNITED STATES

\author{
Chris Wright
}


Copyright @ 2014 Chris Wright

ISBN 978-1-63263-432-0

All rights reserved. No part of this publication may be reproduced, stored in a retrieval system, or transmitted in any form or by any means, electronic, mechanical, recording or otherwise, without the prior written permission of the author.

Published by BookLocker.com, Inc., Bradenton, Florida.

Printed in the United States of America on acid-free paper.

BookLocker.com, Inc.

2014

First Edition 


\section{DEDICATION}

This book is dedicated to all who are fighting for a more humane world. 



\section{DISCLAIMER}

This book details the author's personal experiences with and opinions about worker cooperatives. The author is not a licensed professional.

The author and publisher are providing this book and its contents on an "as is" basis and make no representations or warranties of any kind with respect to this book or its contents. The author and publisher disclaim all such representations and warranties, including for example warranties of merchantability and advice for a particular purpose. In addition, the author and publisher do not represent or warrant that the information accessible via this book is accurate, complete or current.

The statements made about products and services have not been evaluated by the U.S. government. Please consult with your own legal or accounting professional regarding the suggestions and recommendations made in this book.

Except as specifically stated in this book, neither the author or publisher, nor any authors, contributors, or other representatives will be liable for damages arising out of or in connection with the use of this book. This is a comprehensive limitation of liability that applies to all damages of any kind, including (without limitation) compensatory; direct, indirect or consequential damages; loss of data, income or profit; loss of or damage to property and claims of third parties.

You understand that this book is not intended as a substitute for consultation with a licensed medical, legal or accounting professional. Before you begin any change your lifestyle in any way, you will consult a licensed professional to ensure that you are doing what's best for your situation. 


\section{WORKER COOPERATIVES AND REVOLUTION}

This book provides content related to cooperatives and political activism. As such, use of this book implies your acceptance of this disclaimer. 


\section{TABLE OF CONTENTS}

CHAPTER ONE - INTRODUCTION .................................................... 1

CHAPTER TWO - THE SOCIOLOGY AND ECONOMICS OF

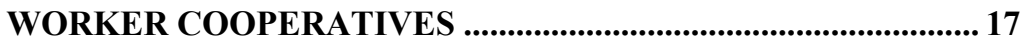

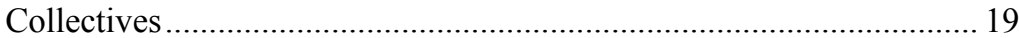

Organizational structure ........................................................... 19

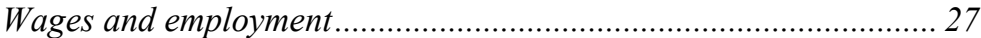

Incentives, job satisfaction, productivity, and "the political effects of participation "........................................................................ 30

Medium-sized and larger cooperatives............................................... 37

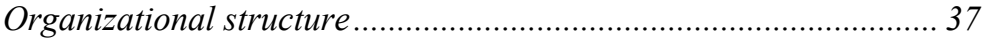

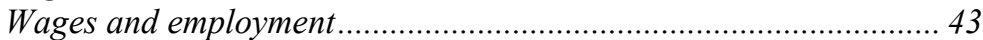

Incentives, job satisfaction, productivity, and the political effect

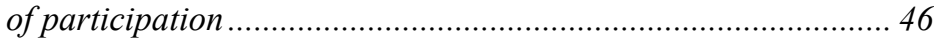

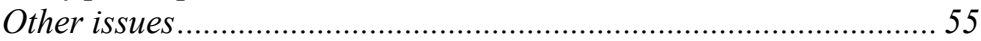

CHAPTER THREE - WORKER COOPERATIVES IN AMERICAN HISTORY ............................................................... 71

CHAPTER FOUR - MARXISM AND THE ALTERNATIVE

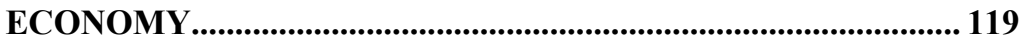

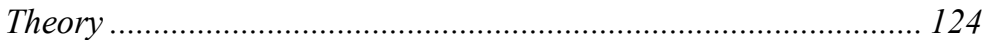

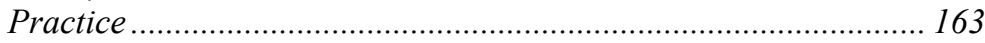

CHAPTER FIVE - NEW ERA .................................................................. 201

CHAPTER SIX - CONCLUDING THOUGHTS ON

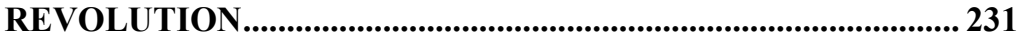





\section{CHAPTER ONE INTRODUCTION}

The capitalist mode of production does not permit a socially efficient allocation of resources. Resource allocation is determined by the twin structural imperatives of having purchasing power (on the demand side) and of chasing profit (on the supply side). If one has a need but lacks the money to back up that need, as for example the billion children worldwide living in poverty do, one's need will not be met by the market. Conversely, investors will pursue only those projects that have the potential to make a profit. For example, many areas of rural America were still without electricity in the early 1930s because investors had judged that the meager profits to be made did not justify the costs of supplying electricity to these regions; hence the New Deal's Rural Electrification Administration and the cooperatives that sprang up to supply electricity. ${ }^{1}$

Broadly speaking, the dynamic between capital and wage-labor, as well as that between millions of atomized units of capital each seeking profit at the expense of every other, makes for a very unstable and crisis-prone economy. Capital's interests lie in paying the worker as little as possible and in preventing him from exercising control over the process of production, while the worker wants to be paid as much as possible and to exercise greater control over production. This simple structural antagonism is the basis for the whole history of the labor movement, the continual confrontations, the unions and union-busting, the private armies deployed to break up strikes, the government suppression of labor parties, the revolutionary social movements, the constant and pervasive stream of business propaganda, and the periodic bursts of cooperative economic activity among the ranks of labor. At the same time, the vicissitudes of the capitalist economy leave many people unemployed at any given time, unable to find work because their

\footnotetext{
${ }^{1}$ Deward Clayton Brown, Electricity for Rural America: The Fight for the REA (Westport, CT: Greenwood Press, 1980).
} 
skills and needs are not valued or because of insufficient investment in their geographical or professional area, or because of outsourcing to countries where labor is cheaper, or for other reasons. In recent decades, the liberalization and financialization of the international economy has entailed a tendency for corporations to seek profits not through investment in industry and infrastructure-development but through financial speculation. This sort of investment, undertaken on the principle of "Après moi le déluge," is not only risky but essentially adds no jobs and no real wealth to the economy, which tends to stagnate - or to contract, after it finally becomes evident that all these financial transactions have been grounded in "the baseless fabric of a vision" (to quote Shakespeare). So, millions more people are thrown out of work as capital withdraws itself from further investments, and government initiatives are required to set the economy on track again-for more financial speculation and more stagnation, as opposed to contraction. ${ }^{2}$

However, even before the orgies of neoliberalism it was obvious that capitalism is not socially efficient. Market failures are everywhere, from environmental calamities to the necessity of the state's funding much socially useful science to the existence of public education and public transportation (not supplied through the market) to the outrageous incidence of poverty and famine in countries that have had capitalism foisted on them. ${ }^{3}$ All this testifies to a "market failure," or rather a failure of the capitalist, competitive, profit-driven mode of production, which, far from satisfying social

${ }^{2}$ See John Bellamy Foster and Robert McChesney, "Monopoly-Finance Capital and the Paradox of Accumulation," Monthly Review 61, no. 5 (October, 2009): 1-20; and John Bellamy Foster and Robert McChesney, The Endless Crisis: How Monopoly-Finance Capital Produces Stagnation and Upheaval from the U.S.A. to China (New York: Monthly Review Press, 2012).

${ }^{3}$ Naomi Klein describes recent examples in The Shock Doctrine: The Rise of Disaster Capitalism (New York: Henry Holt and Company, 2007). Walden Bello gives other examples in The Food Wars (London: Verso, 2009). 
needs, multiplies and aggravates them. This should not be surprising. An economic system premised on two irreconcilable antagonismsthat between worker and supplier-of-capital and that between every supplier-of-capital and every other ${ }^{4}$ - and which is propelled by the structural necessity of exploiting and undermining both one's employees and one's competitors in order that ever-greater profits may be squeezed out of the population, is not going to lead to socially harmonious outcomes. Only in the unreal world of standard neoclassical economics, which makes such assumptions as perfect knowledge, perfect capital and labor flexibility, the absence of firms with "market power," the absence of government, and in general the myth of homo economicus - the person susceptible of no other considerations than those of pure "economic rationality"-is societal harmony going to result.

From the very beginning of its history, the manifold social evils of capitalism have given rise to oppositional movements. The one I am concerned with in this book is cooperativism, specifically worker cooperativism. There are many other kinds of cooperatives, including those in the credit, agriculture, housing, insurance, health, and retail sectors of the economy. But worker cooperativism is potentially the most "oppositional" form, the most anti-capitalist, since it organizes production in anti-capitalist ways. Indeed, the relations of production that constitute worker cooperativism also define socialism in its most general sense: workers' democratic control over production and, in some varieties, ownership of the means of production (whether such ownership is organized individually, by owning shares of equity, or collectively). As one common formulation states, in the worker co-op, labor has power over capital, or "labor hires capital." In the conventional business, by contrast, capital has power over labor, i.e., "capital hires labor." None of the other kinds of cooperativism directly rejects these capitalist power-relations, although some may signify an implicit

\footnotetext{
${ }^{4}$ Capitalists may indeed reach a modus vivendi to alleviate the mutually harmful consequences of competition, for instance by fixing prices, but the potential always remains for the antagonism of interests to reassert itself.
} 
undermining of capitalism insofar as the co-op exists not primarily for the sake of maximizing profit but for satisfying some social need.

It must be understood that a society's dominant mode of material production, i.e., the "hegemonic" method of organizing the relations of material production (such as manufacturing and food production), conditions the overall character of the society more than any other of its features does. This is because the society is erected on the basis of material production; the first task for a society is to reproduce itself in its specific form, which presupposes the reproduction of a set of production relations. Social relations will tend to evolve that make possible the reproducing of the relations of production. In the spheres of economic distribution, of politics, of sexual relations, of intellectual production, and so on, social structures and ideologies will tend to predominate that are beneficial, "functionally selected" with respect to the dominant mode of production. ${ }^{5}$ Therefore, a movement that aims for fundamental transformations in society should not limit itself to the sphere of distribution, as do consumer co-ops, credit unions, and housing co-ops, nor the sphere of gender relations, as does the feminist movement, but should concentrate on changing the mode of production (with its correlative property relations), as does worker cooperativism.

${ }^{5}$ Philosophers have debated interminably the validity or invalidity of "functional explanation" and the notion of "functional selection," but in fact functional explanations are simply shorthand versions of causal explanations - as in Darwinism, whose talk of the "functions" of particular biological adaptations is a way of rephrasing the causal doctrine of natural selection by means of random variation. To say, as G. A. Cohen does in Karl Marx's Theory of History: A Defence (1978), that historical materialism is committed to functional explanation is misleading. It is "committed" only to causal explanations, but Marxists often use the idiom of functionalism because to tease apart all the causal mechanisms through which particular structures, patterns of behavior, and ideologies have developed and persisted is no easy task. I'll return to this issue in the final chapter. 
Such cooperativism on a societal scale, involving "a federation of free communities which shall be bound to one another by their common economic and social interests and shall arrange their affairs by mutual agreement and free contract, ${ }^{, 6}$ is not only a more socially rational way of organizing production than capitalism but also a more intrinsically ethical way (even apart from its potential allocative efficiencies). First of all, the very premises of capitalism are absurd, as Michael Albert makes clear:

Rewards for [owning] property are called profit... wherein individuals who own the means of production pocket profits based on the amount of those means of production. You own some machines. The machines have high output that can be sold for revenues that exceed the cost of maintaining them. You pocket the difference, or profit. You needn't do anything other than keep track of your deed to your property, while sipping mint juleps or dry martinis. ${ }^{7}$

More pertinent, however, is that capitalism tends to stultify the worker's creativity, his human urge for self-expression, freedom, mutually respectful interaction with others, recognition of his selfdetermined sense of self, recognition of himself as a self rather than an object, a means to an end. Karl Marx called it "alienation." Capitalism alienates the worker-and the capitalist-from his "fundamental human need" for "self-fulfilling and creative work," "the exercise of skill and craftsmanship," ${ }^{8}$ in addition to his

\footnotetext{
${ }^{6}$ Rudolf Rocker, Anarcho-Syndicalism: Theory and Practice (Oakland: AK Press, 2004), 1.

${ }^{7}$ Michael Albert, Moving Forward: Program for a Participatory Economy (San Francisco: AK Press, 2000), 17. That many owners of capital do productive work (managerial, technical) is not essential to their ownership of capital considered in itself. It is this from whence they derive their profits.

${ }^{8}$ Noam Chomsky, Language and Politics (Oakland: AK Press, 2004), 364.
} 
fundamental desire to determine himself (whence comes the desire to dismantle oppressive power-relations and replace them with democracy). Alternative visions of social organization thus arise, including Robert Owen's communitarian socialism, Charles Fourier's associationist communalism, Proudhon's mutualism (a kind of anarchism), Marx's communism, Bakunin's collectivist anarchism, Kropotkin's anarchist communism, Anton Pannekoek's council communism, and more recently, Murray Bookchin's libertarian municipalism, Michael Albert's participatory economics, Takis Fotopoulos's inclusive democracy, Paul Hirst's associationalism, and so on. Each of these schools of thought differs from the others in more or less defined ways, but they all have in common the privileging of economic and social cooperation and egalitarianism.

I take these visions to be essentially similar to "worker cooperativism," which in some form is at least an element in all of them. If it were generalized so as to be the dominant mode of production, a society approximating classical utopias would be achieved. In this book, however, my primary focus is not on cooperativism's value as the ideal we strive for, but on its value as a possible path towards that ideal. That is, I want first of all to evaluate the potential of worker co-ops for undermining capitalism and moving us towards something like "socialism," or economic democracy. What should be their strategic role? What systemic effects have they had in the past? What mistakes have been made? How have co-ops fared as a form of business? Do they indeed tend to entail workplace disalienation and democracy, or is that just a theoretical construct that doesn't obtain in reality? Can their potentially revolutionary function be reconciled with their need to survive in a capitalist economy? What sort of political consciousness has their membership tended to possess? How have co-ops interacted with the labor movement? What challenges do they face as businesses? Why are they so rare?

Opponents of capitalism have by no means always looked favorably on worker co-ops as tools of revolution. We'll have to consider their arguments in the following chapters. Marx had an 
ambivalent attitude toward co-ops: he considered them to "represent within the old form [i.e., the capitalist economy] the first sprouts of the new" but thought that "they naturally reproduce, and must reproduce, everywhere in their actual organization all the shortcomings of the prevailing system." Not until the working class had seized political power and imposed cooperative principles on the economy could co-ops be anything more than aberrations. Lenin and other Marxists agreed with this judgment. Nikolai Bukharin accused "pre-revolutionary" cooperators of being "purveyors of a "miserable reformist utopia' because they imagined a socialist evolution of cooperatives within the capitalist system...cooperatives 'inescapably fall under the influence of capitalist economics'... and 'are transformed into capitalist enterprises." "10

Edward Greenberg observes that members of worker cooperatives occupy what Erik Olin Wright has called "contradictory class locations." 11 "In producer cooperatives, democratic participation is joined to actual ownership of the enterprise so that shareholders are, at one and the same time, workers and capitalists." 12 Because of their contradictory structural locations they have contradictory interests and incentives, desiring both the maximization of profit and workplace democracy and equality. They might also, in their capacity as workers, identify with employees of conventional companies in their struggles against management, perhaps going so far as to join a union, to strike or boycott sympathetically in solidarity with their oppressed brethren, to participate in radical social movements - or they might renounce unions and the class struggle altogether and act solely as entrepreneurs. We'll look at examples of this behavior later.

In chapters two and four I'll consider arguments for and against co-ops in depth. We'll see that the issues are not quite as simple as

\footnotetext{
${ }^{9}$ Marx, Capital, Vol. 3, Part V, Chapter 27.

${ }^{10}$ Quoted in Edward S. Greenberg, Workplace Democracy: The Political Effects of Participation (Ithaca: Cornell University Press, 1986), 153.

${ }^{11}$ See Erik Olin Wright, Classes (London: Verso, 1985).

12 Greenberg, Workplace Democracy, 153.
} 
Marxist opponents and anarchist proponents have sometimes thought. Cooperatives can behave in different ways, and much depends on their institutional context. Some cooperators rhapsodize about their experiences while others profess disillusionment. What factors explain these differences? I also want to consider two additional questions: first, can co-ops have a viable role in alleviating on a broad scale, within the capitalist economy, the worst defects of capitalism? Second, is such a role in tension with the goal of eventually transcending capitalism, in that it tends to stabilize the economy and contain discontent, postponing the necessary direct attack on capitalist institutions? Or, on the contrary, can the propagation of co-ops in the interstices of capitalism be an element in the long-term formation of a counter-hegemony? That these questions are imperative is revealed by the fact that not only leftists but even conservatives and fascists have at times favored worker coops. Mussolini granted official recognition to the Italian cooperative movement once it had purged Socialists and Communists, and he pointed to cooperatives as embodying "worker participation, nonconflictual relations between labor and management, and the withering away of class identifications." ${ }^{13}$ In the famous Spanish town of Mondragon, worker cooperativism was founded (in the 1950s) "as an entrepreneurial alternative to working-class activism and socialism." 14 There is a danger, therefore, that cooperatives can become tools of reaction rather than progress.

In chapter two I'll discuss cooperatives from a non-revolutionary perspective, culling the scholarly literature for insights into organizational structure, methods of capitalization, labor productivity, worker satisfaction, wage levels, profitability, effects on employment, company survival-rates and longevity, challenges the movement faces, etc. Chapter three is devoted to the history of worker cooperativism in the United States. I will show, among other

${ }^{13}$ Sharryn Kasmir, The Myth of Mondragon: Cooperatives, Politics, and Working-Class Life in a Basque Town (Albany: State University of New York Press, 1996), 75.

${ }^{14}$ Ibid., 195. 
things, that in an overall framework of powerful institutional obstacles, worker cooperativism has periodically surged forward and then receded in a cyclical pattern. After its advances, conservative political and economic forces have pushed back to virtually eradicate it. For example, under the sponsorship of the Knights of Labor it made great headway in the 1870 s and $1880 \mathrm{~s}$; in the late 1880 s and the 1890s it succumbed to the attacks of big business on industrial unionism, which also decimated the Knights of Labor. Cooperativism made strides in the 1930s, partly with the help of New Deal legislation, but in the 1940s and '50s it receded again. The 1960s and '70s saw further advances under the influence of such progressive movements as the civil rights, youth, anti-war, and feminist movements, while the 1980s saw massive counterattacks by conservative sectors of business. This whole history arises from the violent and cyclically prone conflict between capital and labor (in occasional conjunction with other progressive interests like the black struggle against racialized capitalism).

I'll apply the lessons from chapter three in the following chapter, where I discuss the question of what co-ops and the growing "alternative economy" can contribute to a long-term struggle against capitalism. This discussion will be more theoretical and speculative than that in the second chapter-inevitably so, since one can only speculate about the future, not analyze it. But since people study the past precisely to glean lessons for the future, a semi-theoretical, semi-empirical analysis of possibilities seems appropriate.

To anticipate: I expound and revise the Marxist theory of revolution so as to provide a theoretical framework to interpret the alternative economy (of cooperatives, municipal enterprise, public banking, etc. - the solidarity economy in general). Marxists and "cooperators" have tended to be mutually hostile, but, as I'll explain, the logic of Marxism is in fact committed to the sorts of "interstitial" movements that are emerging now, which represent a new society within the shell of the old. Marx himself misunderstood his own system when he adopted a statist perspective and predicted a dictatorship of the proletariat - two things that are very un-Marxian, as we'll see. His followers persisted in his mistakes, such that up to 
the present day virtually no one has understood the elementary truth that statism and Marxism are in conflict (in two ways, actually: morally and strategically). So, I purify Marxism, returning it to its logical essence. The reason for doing this isn't only to make some academic points about doctrine; instead, I think that if the theory of revolution is purified and updated it sheds light on the historical moment we're living in.

To illuminate that moment, I retrace the logic of the West's historical development in the last few centuries. The notion of a "logic of history" isn't fashionable nowadays, probably because it implies that capitalism is merely a temporary phase that, like all social systems, is bound to evolve into something different. Nevertheless, I resurrect the idea and use it to explain why only now are we finally entering the revolutionary era Marx and Engels looked forward to - and why it couldn't have been any other way. They got the timeline wrong; "socialism" on a broad scale was not possible earlier. But the coming revolution will not look like what they predicted, namely a seizing of the state and a unitary reconstruction of the economy. Rather, it will take place over generations and will sprout from the grassroots, locally, regionally, and transnationallyagain, as Marxism (despite Marx) entails. Given a true revolutionary situation, cooperatives are by no means antithetical to the class struggle; they are an essential tool of it.

Chapter five returns to the focus on worker cooperatives, this time looking at their formation. In particular, I recount the experience of a business that was recently formed and has frequently been in the press, the New Era Windows cooperative in Chicago. Its worker-owners are the same workforce that occupied the Republic Windows and Doors factory in 2008, just as it was closing, to demand the back pay, severance, and temporary healthcare benefits to which they were entitled. It was one of the very few factory occupations since the $1930 \mathrm{~s}$, and it became a national cause célèbre 
that even President-elect Obama spoke positively about. ${ }^{15}$ A couple months after the workers' victory the factory was partially reopened under a new owner, Serious Materials - which three years later, in February 2012, announced that it was closing the factory again and consolidating operations elsewhere. So, once again, the workers staged a sit-in to protest the closing, which ended after the owners agreed to keep the factory open for ninety days. Fed up with capitalist caprice, the workers decided to buy the factory themselves and run it as a cooperative. Again they encountered resistance from the business class, but with determination and community support they overcame it. I tell their story in some detail in chapter five.

The point of this case-study isn't only to tell an inspiring story of David triumphing over Goliath. I'm also interested in how and why these workers have succeeded where others have failed or not even tried. Why were they apparently the only workforce in the U.S. to occupy their factory in the dismal months of late 2008 and early 2009, when the economy was imploding? What ingredients were present that were missing elsewhere? Why and how did they decide to start a cooperative? How did they force the owners, who were initially reluctant, to let them buy the factory? What steps were required to establish the cooperative? Has the experience been successful so far? What challenges have had to be overcome along the way? In general, I try to glean lessons that can be applied in similar cases, which I hope and expect will become more common in the coming decades.

In the final chapter I return to the topic of Marxism and revolution, to discuss some implications of the ideas in chapter four. I argue, for example, that the old mutual hostility of Marxism and anarchism is seen to be unfounded upon a deeper understanding of Marxism, and that leftists should therefore move beyond the sectarianism that has interfered with radical movements for at least 150 years. On the other hand, if my revision of Marxism succeeds in

${ }^{15}$ Monica Davey, "In Factory Sit-In, an Anger Spread Wide," New York Times, December 7, 2008. 
returning it to its "essence," it becomes even clearer than it was to Rosa Luxemburg that Leninism is a deviation from Marxism. According to the latter, and to any sensible revolutionary strategy, the transition to a new society will take place over many generations and will involve every conceivable tactic, including radical political parties, frequent mass demonstrations, violent confrontations with armed personifications of authority, transnational federations of peasant and worker solidarity, pressures from the environmental movement to end destructive capitalist practices, and, crucially, the construction of new cooperative modes of production and distribution in the womb of the old regime. Activists should have a clear understanding that this is what we're in for; this broad-based "movement of movements" is what we should expect and embrace.

Thus, an essential element in this movement of movements is the worldwide spread of co-ops (of every kind) that is happening now. Indeed, we are living in the most exciting time for cooperativism since capitalism began its conquest of the world. Cooperatives proliferate from Canada to Argentina, across Europe and Russia, to India and over to Indonesia, throughout Africa and the Middle East. Almost 800 million people are members of cooperatives, and three billion depend on them for their livelihood. ${ }^{16}$ The developing world has made excellent use of the cooperative principle, in the form, for example, of microcredit, which is - or can be - a kind of cooperative banking. Neoliberal institutions like the IMF and World Bank, far from facilitating sustainable economic development, have typically amounted to imperialism and colonialism by other means, functioning so as to permit the transfer of wealth from the poor to the rich and from poor countries to rich countries. As a result, regions such as South Asia have, in some respects, begun to reject the neoliberal model in favor of such strategies as establishing institutions that grant small loans with little or no interest to villagers, usually women - which, incidentally, empowers them vis-

${ }^{16}$ International Cooperative Alliance (ICA), "Co-operative Facts and Figures," http://ica.coop/en/whats-co-op/co-operative-facts-figures (accessed December 13, 2013). 
à-vis men-for the purpose of starting businesses or buying houses for their families. In Bangladesh, such institutions have helped over 10 million people escape from dire poverty. ${ }^{17}$ In recognition of the fact that cooperatives "are becoming a major factor of economic and social development" - as the General Assembly of the UN declared in $2002^{18}$ - the UN named 2012 the International Year of the Cooperative.

Cooperatives have had success in the developed world too, as the following random statistics show. In France, farmers borrow up to 90 percent of their loans from credit cooperatives; cooperative banks handle 60 percent of total deposits; and 28 percent of all retailers are cooperatives. ${ }^{19}$ Ninety-one percent of Japanese farmers belong to agricultural co-ops. In the United States, a number of well-known corporations are technically cooperatives, including Land O'Lakes, Sunkist, Ocean Spray, Welch's, Sunmaid, REI, the Associated Press, and True Value Company. Credit unions in the U.S. had 95 million members in 2012, or 45 percent of the economically active population..$^{20}$ Electric utility co-ops provide electricity to more than 42 million rural Americans; 1.2 million families live in homes owned

\footnotetext{
${ }^{17}$ Richard Williams, The Cooperative Movement: Globalization from Below (Burlington, VT: Ashgate Publishing Company, 2007), 84. Unfortunately, banks have discovered in microcredit a brave new world of exploitation-ofthe-poor, and so are beginning to dominate the field even though they often charge interest rates of 100 percent or more. Neil MacFarquhar, "Big Banks Draw Big Profits From Microloans to Poor," New York Times, April 13, 2010.

${ }^{18}$ John Curl, For All The People: Uncovering the Hidden History of Cooperation, Cooperative Movements, and Communalism in America (Oakland, CA: PM Press, 2012), 7.

${ }^{19}$ Lanyan Chen, Gender and Chinese Development: Towards an Equitable Society (New York: Routledge, 2008), 23; Coop FR, "Key Figures," http://www.entreprises.coop/decouvrir-les-cooperatives/chiffres-cles.html (accessed December 13, 2013).

20 World Council of Credit Unions, "2012 Statistical Report," http://www.woccu.org/publications/statreport (accessed December 13, 2013).
} 
or operated by cooperative associations; and over 11,000 social and public service cooperatives exist - e.g., cooperative daycare centers, which serve more than 50,000 families. ${ }^{21}$ Altogether there are about 30,000 cooperatives in the U.S., providing two million jobs and generating more than 600 billion dollars in revenue. ${ }^{22}$

Of all forms of cooperative economic activity, worker cooperativism has had the most troubled history. And yet it too has had notable successes. Consider Europe again. Confining our attention to recent times, the European Confederation of Worker Cooperatives reports that the 50,000 enterprises affiliated with it employ about 1.4 million people. ${ }^{23}$ Italy has a particularly high proportion of worker co-ops - the highest per capita in the worlddue in part to legal advantages. ${ }^{24}$ The Mondragon cooperative complex in Spain has had well-publicized success since it was established in the $1950 \mathrm{~s}$, eventually diversifying its operations from industry to retail, agriculture, education, housing, and research and development. Currently it comprises about 250 companies that together employ 80,000 people and have annual sales of 13 billion euros, elevating Mondragon into the class of major multinational corporations. ${ }^{25}$

Worker cooperativism has recently been spreading in Latin America, as societies try to piece themselves together in the wake of

${ }^{21} 2012$ International Year of the Cooperative, "Quick Facts about U.S. Coops," http://usa2012.coop/co-ops-in-usa/quick-facts; University of Wisconsin Center for Cooperatives, "Research on the Economic Impact of Cooperatives," http://reic.uwcc.wisc.edu/services/ (accessed December 13, 2013).

${ }^{22}$ ICA, "Cooperative Facts and Figures"; 2012 International Year of the Cooperative, "Quick Facts about U.S. Co-ops."

${ }^{23}$ CECOP, "What is CECOP?" http://www.cecop.coop (accessed December $13,2013)$.

${ }^{24}$ Gregory K. Dow, Governing the Firm: Workers' Control in Theory and Practice (New York: Cambridge University Press, 2003), 67-69; Erbin Crowell, "Cooperating Like We Mean It: The Co-operative Movement in Northern Italy," Grassroots Economic Organizing, http:// www.geo.coop.

${ }^{25}$ Mondragon Corporation, http://www.mondragon-corporation.com. 
neoliberal economic destruction. For example, factory takeovers by former employees were quite common in Argentina after the collapse of 2001; the new worker-owners have organized their companies on a cooperative basis. ${ }^{26}$ Some of these firms have won important legal battles that have affirmed their right to expropriate the property of the old failed business. ${ }^{27}$ After ten or more years - a long time even for conventional firms - many of these "recovered companies" are still in business. The same phenomenon has occurred in Brazil, perhaps on an even broader scale, as its solidarity economy has grown. ${ }^{28}$

The United States has often lagged with respect to progressive movements, and worker cooperativism is no exception. Currently there are only about 300 or 350 such co-ops in the country, and most of them are small to medium-sized. ${ }^{29}$ (Employee stock-ownership plans (ESOPs), by contrast, are quite common, with 11,000 of them operating today. ${ }^{30}$ Nevertheless, the movement is growing. For example, the U.S. Federation of Worker Cooperatives was founded in 2004; smaller such federations and support organizations

${ }^{26}$ The Lavaca Collective, Sin Patrón: Stories from Argentina's Worker-Run Factories (Chicago: Haymarket Books, 2007). See also Karen Ann Faulk, "If They Touch One of Us, They Touch All of Us: Cooperativism as a Counterlogic to Neoliberal Capitalism," Anthropological Quarterly 81, no. 3 (2008): 579-614; and Peter Ranis, "Argentina's Worker-Occupied Factories and Enterprises," Socialism and Democracy 19, no. 3 (Nov. 2005): 1-23.

${ }^{27}$ See, for instance, Marie Trigona, "Argentine Factory Wins Legal Battle: FASINPAT Zanon Belongs to the People," Upside Down World, August 14, 2009.

${ }^{28}$ Mario Osava, "Solidarity Economy Combats Exclusion," Inter Press Service, January 11, 2008, http://ipsnews.net/news.asp?idnews $=40760$ (accessed May 10, 2010). See chapter four of this book.

${ }_{29}$ U. S. Federation of Worker Cooperatives, "What is a Worker Cooperative?," at http://www.usworker.coop/about/what-is-a-worker-coop (accessed December 13, 2013).

${ }^{30}$ Gar Alperovitz, America Beyond Capitalism (Hoboken, New Jersey: John Wiley \& Sons, Inc., 2005), 87. 
proliferate across the country, for instance the Network of Bay Area Worker Cooperatives in the San Francisco area (formed in 1994), the Valley Alliance of Worker Cooperatives in Massachusetts (formed in 2005), the Eastern Conference for Workplace Democracy, the Federation of Workplace Democracies in Minnesota (from 2004), the New York City Network of Worker Cooperatives, the Ohio Employee Ownership Center (from 1987), the ICA Group, the Cooperative Fund of New England, Green Worker Cooperative (based in the Bronx), the Cooperative Development Institute, the National Cooperative Business Association (founded in 1916), and many more. Even the organizations not exclusively devoted to supporting worker co-ops have recently been getting more involved with them, as public awareness and interest have increased.

The worldwide growth of economic cooperation unreported by the corporate media suggests that we are witnessing the beginning of a social movement the likes of which have never been seen in history. It is quietly sweeping the earth, altering life for millions, but it has barely yet emerged from its infancy. For two centuries its scouts have forged ahead, so to speak, effectively building interstitial redoubts from which in part to wage the future war. And it will be waged, in the coming decades. Compared to this underlying economic evolution, the political headlines of today are little more than epiphenomena. Worker and consumer cooperativism, the social economy, the solidarity economy, local participatory democracy, public banking, regional economic coordination-all this represents the future. The following will establish this claim in broad outline, by taking worker cooperatives as emblematic of larger trends. 


\section{CHAPTER TWO \\ THE SOCIOLOGY AND ECONOMICS OF WORKER COOPERATIVES}

The first question we have to answer is how to define a worker cooperative. Numerous definitions have been offered, all of which share the same intuitions about democratic ownership and control. Here is Derek Jones's definition:

....an autonomous enterprise in which (a) many workers (or members) own stock, (b) ownership is widely distributed among the workers, who own much of the voting stock, (c) working-members participate in the enterprise's management and control, and (d) they share in the distribution of the surplus, usually on the basis of work [rather than stock ownership]. ${ }^{31}$

Like most commentators, he distinguishes cooperatives from mere employee-owned firms, for instance those that have ESOPs, which do not require employee participation in their management.

As stated in the last chapter, the conceptual starting-point of the worker co-op is that labor has power over capital, whereas it is the reverse in a conventional business. That is, in a capitalist enterprise both ownership and control (and the right to a share in profits) ultimately belong to investors, and voting rights are proportionate to the number of shares of equity held. The more capital one owns, the more control one is supposed to have over the operations of the firm. In the co-op, control is not directly related to ownership: the principle is "one worker, one vote," not "one share, one vote." Moreover, all or the majority of shares — if stock exists at all—are

${ }^{31}$ Derek Jones, "American Producer Cooperatives and Employee-Owned Firms: A Historical Perspective," in Worker Cooperatives in America, eds. Robert Jackall and Henry M. Levin (Berkeley: University of California Press, 1984), 37. 
owned by workers, not outsiders. Otherwise there would be the danger that investors could acquire all the power, which would lead to the business's degeneration into a capitalist firm.

In a traditional business, the only consideration that really matters is the accumulation of profit. All else is subordinated to this goal. In a co-op, the dominant consideration is whatever the workforce wants it to be, for example the maintenance of steady employment, service to the community, or the accumulation of profit (to be allocated as the members decide). We'll see below that, as a rule, workers prefer the continued employment of as much of the workforce as possible to the retention of high revenues, which in hard times means that they accept pay cuts in order to avoid layoffs.

The typical governance structure of a cooperative follows from what has been said. In large cooperatives, a board of directors, drawn from the ranks of the worker-members themselves, is elected by the workforce and managers are appointed by the directors (or sometimes elected directly by members). Both directors and managers, therefore, have an incentive to treat workers well and respect their priorities, since if they don't, they might be voted out of their position. Small co-ops, on the other hand, have little "governance structure" at all: they tend to operate by (near)consensus and have no need of managers or directors. Occasionally there is a nominal "board of directors" for minor decisions or for administrative matters with which other members do not want to concern themselves.

Already, a major reason for the rarity of worker co-ops is evident: investors have a greater incentive to invest in firms that give capital control over labor rather than vice versa. Hence, it will frequently be the case that people cannot raise enough capital to get a cooperative started or to keep it functioning. Investors' interest is in the extraction of maximum profit regardless of the will of the workers; indeed, the interest of the latter, as employees, is directly opposed to the interest of capital, since profit is inversely proportional to wages. Investors will therefore be reluctant to deposit their funds in a firm that gives control to its workers, who do not value the maximization of profit above all else. 
At the same time, cooperatives are motivated, as I said, not to seek large amounts of outside investment, since then it might be difficult to prevent control from effectively falling into the hands of these investors, an eventuality that could lead to the erosion of the firm's commitment to democratic ideals. The usual practice among co-ops is to rely primarily on initial investments in the firm by its members (who thereby gain a share in ownership), ${ }^{32}$ in conjunction with loans from cooperative banks or other institutions ideologically committed to cooperativism. But it remains true, for the reasons mentioned and others to be examined below, that raising sufficient capital is one of the biggest obstacles to the spread of worker cooperatives - and, as a corollary, that cooperatives have preponderated in non-capital-intensive industries.

However, let's consider these questions and others in more detail, drawing upon the scholarly literature. I will discuss small cooperatives, sometimes called "collectives," first, since they are the most numerous.

\section{Collectives}

\section{Organizational structure}

Collectives approach most closely the participatory democratic ideal of cooperation. Being of fewer than, say, 40 people, often as few as 15 or less, there is a minimum of bureaucracy and a maximum of collective decision-making. The values of decentralization, spontaneity rather than bureaucracy, freedom and selfinitiative rather than external imposition of rules, are the guiding lights. In a sense, the structure of collectives can be seen as the ideal that larger cooperatives try to approximate insofar as they are committed to democracy.

${ }^{32}$ Actually, legal structures exist according to which worker-members do not "own" a "share" in equity but receive a portion of the profits anyway. See the final section of this chapter. For now, the differences between legal forms are unimportant. 
As already noted, the collectivist form of governance is directly democratic and usually consensual. Major decisions, and often minor ones, are approved of in meetings attended by all the members; the goal is to hammer out a policy on which everyone agrees. What makes this consensual decision-making possible, of course, is the small size of the business. As one author states, "The face-to-face relationships and directly democratic forms that characterize the collectivist organization probably cannot be maintained if the organization grows beyond a certain size." ${ }^{\prime 3}$ There is no absolute optimal size of cooperatives, though, since the proper size varies with the nature of the work and the technology available. Perhaps Jean-Jacques Rousseau's criterion, suggested in The Social Contract, is best: "each citizen [must] with ease know all the rest." One writer states bluntly that "democracy is inversely proportional to the size of the cooperative," and he advises that co-ops not exceed a size compatible with a general meeting of the members. ${ }^{34}$

For example, in the 1980s the small size (around 25 members) of the Cheese Board, a cooperative in San Francisco that was and is the leading cheese store in the area, made possible a consensual approach to decision-making, with no formally acknowledged "leaders." Any leadership was informal, based on personality and perceived commitment to the co-op. As Robert Jackall noted in a 1983 case-study, when major matters had to be decided upon, "such as the long-term disposal of the growing surplus funds," a consensus was required at one of the monthly meetings. For minor matters, though, a simple majority vote sufficed — or decisions could be made by the shift at the time that an issue arose. Achieving consensus was difficult and time-consuming, sometimes requiring many meetings over many months, as when the business decided to post a sign

33 Joyce Rothschild and J. Allen Whitt, Potentials and Dilemmas of Organizational Democracy and Participation (New York: Cambridge University Press, 1986), 91. Italics in the original.

${ }^{34}$ Tadeusz Kowalak, quoted in ibid., 92. 
publicly proclaiming its status as a collective. ${ }^{35}$ This is one of the reasons why a constant practicing of direct democracy, especially of the consensual sort, is not feasible in large organizations; it would take too long to reach and implement decisions on even minor issues. Representative democracy and a degree of bureaucracy, i.e., of the centralization of power, become essential to getting things done in a timely manner.

(In fact, now that the Cheese Board has expanded to 50 members who also run a bakery and a pizza business, the old requirement of consensus has been partially abandoned. The new rule is that a kind of "modified consensus" is necessary for important decisions: members try to reach agreement, but if they can't, a near-consensus suffices. $)^{36}$

So, the first constraint on democracy is size - of the business and of its market. Equal Exchange, a workers' co-op in Massachusetts with over 100 members that did $\$ 51,046,000$ worth of business in 2012, necessarily has more bureaucracy, more specialized jobs (including customer service, media outreach, etc.), and less democracy than Collective Copies, a copying center with 12 members in Western Massachusetts. ${ }^{37}$ The second constraint, mentioned already, is time. "Quite simply, a boss can hand down a bureaucratic order in a fraction of the time it would take a group to decide the issue democratically." ${ }^{, 8}$ On the other hand, in the latter case the policy might be implemented more effectively, since workers presumably would be more committed to it. Indeed, ironically, the much-maligned inefficiency of bureaucracies is due in large part to their undemocratic nature, their inflexible, impersonal, uncommunicative, unaccountable, unresponsive-to-unforeseen-

${ }^{35}$ Jackall, "Paradoxes of Collective Work," in Worker Cooperatives in America, 122.

${ }^{36}$ Personal communication with a member.

${ }^{37}$ Equal Exchange, "Fast Facts," http://www.equalexchange.coop/fast-facts, and Collective Copies, http://collectivecopies.com/about/staff.htm (accessed November 20, 2013).

${ }^{38}$ Rothschild and Whitt, Potentials and Dilemmas, 64. 
contingencies structure. As Michel Crozier says, "A bureaucratic organization is an organization that cannot correct its behavior by learning from its errors." 39 This is because in centralized organizations, change tends to come only from the top-but at the top are people who usually do not learn of "errors" at the bottom at all. Information does not flow efficiently: the atomized and dispersed nature of their organization isolates bureaucrats from the social and institutional consequences of their actions, preventing them from seeing the broader picture as each performs only a specialized function, always waiting for dictates from on high in lieu of taking initiative. ${ }^{40}$ These failures, and others, of bureaucracy do not apply to democracy.

A third constraint on democracy in worker co-ops is environmental: larger structures in the society have inculcated behavior patterns of submission to authority, competition in the workplace, conformism, and passive atomization rather than active participation in decision-making. One finds in the scholarship descriptions of cooperators who simply do not have the desire to participate in the governance of the firm, who want only to get their paycheck and not deal with the challenges of deciding policy. This is one origin of the old elitist accusation that "the masses" want to be subordinate, that they have neither the capacity nor the inclination to exercise democratic self-control. However, as one sociologist concludes, "We learn to participate by participating... The experience of a participatory authority structure might be effective in diminishing tendencies toward non-democratic attitudes in the individual." ${ }^{41}$ To say it in a different way:

${ }^{39}$ Michel Crozier, The Bureaucratic Phenomenon (London: Tavistock Publications, 1964), 187.

${ }^{40}$ To take a random example, Lawrence Wright's The Looming Tower: AlQaeda and the Road to 9/11 (New York: Knopf, 2006) explains how the CIA's and FBI's bureaucratic overspecialization resulted in the 9/11 attacks.

${ }^{41}$ Carole Pateman, quoted in Rothschild and Whitt, Potentials and Dilemmas, 67. 
If one accepts the assumption [that certain people "are not ripe for freedom"], freedom will never be achieved; for one cannot arrive at the maturity for freedom without having already acquired it; one must be free to learn how to make use of one's powers freely and usefully... ${ }^{42}$

As Kant goes on to say, the first gropings toward freedom and democracy by a people not used to it may be clumsy or ineffectualespecially if the experiments in freedom (such as worker cooperatives) are situated in a still-unfree society. Actually, a lack of involvement by some worker-owners in the affairs of governance is less a problem in collectives than in larger cooperatives. But the point holds: the cooperative's structure and the expectations or pressures that go along with it are in tension with those of the broader society, and this fact can undermine the co-op's smooth democratic functioning inasmuch, for example, as lazy and undemocratic attitudes have to be overcome, and individuals with competitive or authoritarian personalities have to be persuaded to soften their behavior.

One way to avoid these sorts of problems is to be selective in admitting new members. And collectives often are very selective indeed. The Arizmendi Bakery in Oakland, California is an example:

We watch how [prospective members] work and how they take feedback. We bring people in for twelve hours over several weeks. They shadow someone and try out different tasks and we evaluate them. Then we bring them in for a group interview. If we really connect with them, then we bring them on for a six-month trial candidacy. We train them on specific shifts, and they go to meetings related to the history and other ideas that are important for understanding the collective.

\footnotetext{
${ }^{42}$ Immanuel Kant, quoted in Noam Chomsky, For Reasons of State (New York: Vintage Books, 1973), 393.
} 
By the end of six months, there will have been three different evaluations, which are pretty intense. We give them constructive feedback, time for them to voice their concerns, feedback from their sponsor, who has been working alongside them. Then it goes to a full vote and the candidate has to get a 75 percent positive vote to be invited in. ${ }^{43}$

Joyce Rothschild and J. Whitt go so far as to say that "consensus, an essential component of collectivist decision-making, may require from the outset substantial homogeneity among members. Participants must bring to the process similar life experiences, outlooks and values if they are to arrive at agreements." ${ }^{44}$ To an extent this is obviously true, and the rigorous screening process at Arizmendi testifies to it. But the criterion of homogeneity can surely be overemphasized. For example, Red Sun Press, a printing-anddesign cooperative in south Boston with ten worker-owners, has had a very heterogeneous workforce since its founding in 1973: young and middle-aged, highly educated and less educated, countercultural and mainstream, middle-class and working-class, whites and Hispanics. This fact has not prevented the business from lasting 40 years and being financially successful.

Another factor that can interfere with participatory structures is the sheer exhaustion and stress that can accompany the fusion of "employer" and "employee" roles. This is exacerbated by the fact that cooperators, especially collectivists, sometimes receive less pay than their counterparts in conventional businesses. "Burnout" can set in, and thereby "the experience of feeling constantly overworked, of having too much responsibility and not enough organizational support to carry it out, of never having enough free time for personal pursuits, of constantly being hassled, of, in one worker's phrase,

\footnotetext{
${ }^{43}$ Bernice Yeung, "Running a Business with 26 CEOS," East Bay Express, January 27, 2010 (an interview with Kamil Dawson, a member of the coop).

${ }^{44}$ Rothschild and Whitt, Potentials and Dilemmas, 95. Italics in original.
} 
'losing your soul." ${ }^{45}$ Similarly, in a directly democratic environment, where consensus may be required, interpersonal tensions are prone to flaring up. Disagreements can become personal, and general meetings can be quite stressful. Bureaucracy, therefore, is in some ways easier than democracy: the impersonal environment, the not-having-to-treat-people-as-people, can reduce the potential for emotional conflicts.

Again, though, qualifications are necessary. A member of Red Sun Press, in Boston, observed in an interview with the author that, contrary to what one reads in much of the scholarly literature, working in a co-op is not significantly more stressful than working at a traditional business. "In a conventional workplace," she says, "some of the stress comes from having little power over your working conditions and business decisions. In a co-op, some of the stress comes from having the power-then you are responsible for what happens! Ultimately, having the power is the option I would choose. ${ }^{.46}$ Most cooperators, and probably most people, would agree with her.

Studies in the 1980s and earlier emphasized another manifestation of the collectivist commitment to egalitarianism: "deprofessionalization," or the avoidance of professional specialization due to its bureaucratic, stratifying implications. "In the smaller worker cooperatives," writes one author, "work roles are holistic, specialized knowledge is demystified, and there is frequent task sharing and job rotation." ${ }^{, 47}$ The practice of job rotation (or, in a less extreme form, simply having the option to change one's job) was in part a legacy of the radical origins of the 1960s' and '70s' wave of collectives, but it also arose, and continues to arise, from the very nature of small-scale cooperative work. People working in a business sometimes get bored with their routine and want to learn

\footnotetext{
${ }^{45}$ Jackall, "Paradoxes of Collective Work," in Worker Cooperatives in America, 129.

${ }^{46}$ Interview with Nancy Nichols, June 10, 2010.

${ }^{47}$ Robert Sommer et al., "Consumer Cooperatives and Worker Collectives: A Comparison," Sociological Perspectives 27, no. 2 (1984): 139-157.
} 
something new. This diversification of their skill-set, in fact, may be intimately connected to their sense of self-worth: the more routinized, bureaucratized, bored, and detached from one's activities one is, the less self-esteem (and happiness) one has. Humans crave new challenges periodically, and a life or a job bereft of challenges or opportunities for growth is a terrible thing. In capitalist businesses, where most employees have far less input than management in the firm's operations, the desire for stimulating novelty is subordinated to the bottom-line. In collectives, by contrast, workers often give themselves the opportunity to change their roles, to learn new tasks.

For example, Robert Jackall notes that at the Cheese Board it was possible during the 1980 s to switch jobs occasionally if one had enough initiative. Certain tasks were considered attractive, such as baking bread in the morning, and one could "win" these jobs at least temporarily if his coworkers respected his contributions to the store - in other words, if he "deserved" the job. ${ }^{48}$ In fact, a similar tradition continues today. It requires initiative, but the opportunity is there.

However, such deprofessionalization is not possible in all industries. Sometimes expertise is essential for efficiency, as in the printing-and-design and other high-tech industries. In these cases, job rotation is rare. What does happen, though, is that workers change their jobs if they so desire: e.g., at Red Sun Press, Nancy Nichols was the salesperson for seven years, then became the production manager, then did customer service, and now is the business manager. Still, to the extent that expertise in specialized tasks has become increasingly important in recent decades, deprofessionalization has declined. Similarly, the larger a cooperative is, the more difficult it is to organize job rotations, just as it is more difficult to institutionalize democracy.

${ }^{48}$ Jackall, "Paradoxes of Collective Work," 116. 


\section{Wages and employment}

One of the ways in which cooperatives rectify the injustices of capitalism is by instituting a relatively equal compensation-scheme for their members. While in the U.S. the average ratio of CEO compensation in the Fortune 500 companies to the ordinary worker's has recently been reported as $344: 1,{ }^{49}$ in co-ops the pay-differential between management and the average worker rarely exceeds $4: 1$. In collectives, everyone is usually paid the same amount.

For example, a British study from the 1980s reports that all of the dozens of small co-ops it researched had lower pay-differentials than conventional businesses, and most had little or no differential at all. ${ }^{50}$ At Arizmendi Bakery everyone currently receives about 20 dollars an hour plus a percentage of the year's profits. The workerowners of Mondragon Bookstore and Coffeehouse in Canada earn the same rate of pay. At Equal Exchange, a relatively large co-op, there is a $4: 1$ pay ratio.

On the other hand, collectivists sometimes earn less than their counterparts in private enterprises. One study reports that at a cooperatively run newspaper called the Community News, which had a full-time staff of about 15 people, staffers made between 18 and 25 percent of what they could have made at comparable but "established" journalism jobs. Some workers in fact were paid nothing at certain times, while working a 40- to 60-hour week. At another co-op studied, a medical clinic, some staffers made about 50 percent of what they could have earned at other nursing or counseling jobs for which they were qualified. Volunteers also made up a significant portion of the staff. On the other hand, because of the substantial equality in salaries, such workers as secretaries often earned as much as their 'capitalist' counterparts. ${ }^{51}$

49 Heather Landy, "Behind the Big Paydays," The Washington Post, November 15, 2008.

${ }^{50}$ Chris Cornforth et al., Developing Successful Worker Co-operatives (London: SAGE Publications, 1988), 123, 124.

${ }^{51}$ Rothschild and Whitt, Potentials and Dilemmas, 98, 99. 
Against examples of low pay must be set small co-ops like Home Green Home Natural Cleaning in San Francisco, which was established in 2009 to give employment and decent wages to lowincome Latinas. In addition to the 50 to 100 percent higher earnings the women make at their new job than earlier, they have health insurance now and work in healthier environments, where the cleaning chemicals are not as toxic as in many conventional cleaning companies. A study reports that the worker-owners of another such co-op in California, called Natural Home Cleaning (started in 2003), have tripled their personal income and enjoyed an increase of 70 percent in their household income since they joined the cooperative ${ }^{52}$ In some cooperatives wages might be low but because workers are owners they receive a share of annual profits, which, combined with benefits, often raises their income to above the level at comparable private firms.

The reason for the sometimes-low pay-levels of collectives is not too obscure: it is due to undercapitalization, which means that small cooperatives "sometimes generate little surplus to distribute among their members. ${ }^{" 53}$ Especially in the early days of a cooperative, the lack of external capital might mean that wage-levels have to be kept low in order to capitalize the business. ${ }^{54}$ And in times of recession, cooperators usually choose to lower their wages if the alternative is to lay off members, which they are always extremely reluctant to do. In conventional firms, by contrast, wages are "sticky," hard to change; management typically chooses to lay off employees and let the remaining ones keep an income that is perhaps higher than that of the cooperators who have voted to cut their own wages. ${ }^{55}$ Thus, as

${ }^{52}$ Hilary Abell, "Work and Pay Better at Green Cleaning Coops," Owners at Work, Ohio Employee Ownership Center, vol. 21, no. 1 (Summer, 2009): 6,7 .

${ }^{53}$ John McNamara, "Payment Solidarity: Looking Deeper at the Mondragon Principles," SolidarityEconomy.net, February 28, 2010.

${ }^{54}$ Cornforth, Developing Successful Worker Co-operatives, 123.

${ }^{55}$ In recent years, of course, it has become increasingly common during recessions for capitalist businesses not only to lay off employees but to hire 
one recent study sums up, cooperatives of whatever size tend to have more volatile wages than conventional businesses and less volatile employment. ${ }^{56}$

These facts, of course, merely confirm what common sense would suggest. First of all, members of cooperatives tend to see themselves as part of a community of worker-owners, and they respect each other as belonging to this community. It is reported universally in the literature that the prospect of laying off or firing fellow workers is very painful. This is especially so in collectives, where the communities are tightly knit and people develop bonds of friendship with each other. Even in situations where close friendships do not develop, there usually remains mutual respect and a sense of obligation to each other - a sense of "we're in this thing together." In fact, historically one of the most important goals and functions of cooperatives has been "to provide employment security or to expand the employment base for the local population." This was a key reason for the establishment of both the famous plywood co-ops discussed below and Mondragon, ${ }^{57}$ as well as the green cleaning cooperatives in San Francisco and the Evergreen cooperatives in Ohio (see the next chapter). To lay off workers,

new ones at a much lower rate of compensation. For instance, this is what the Hyatt Hotels and Resorts chain did in Boston in 2009: it laid off a hundred housekeepers who were earning $\$ 15$ or more per hour and outsourced their jobs to others whom it paid $\$ 8$ an hour (even though, because the staff had shrunk, these new housekeepers had to do far more work than the old ones had). Megan Woolhouse, "Firing Housekeepers Creates PR Mess for Hyatt," The Boston Globe, September 25, 2009. Incidentally, as is usually the case in such situations, the broader recession was simply an excuse that Hyatt used to justify its action; in fact, the company was by no means in desperate financial straits. See "Hyatt Hotels posts narrower Q4 new loss" in The Guardian, http://www.guardian.co.uk (accessed March 15, 2010).

${ }^{56}$ John Pencavel et al., "Wages, Employment, and Capital in Capitalist and Worker-Owned Firms," Industrial and Labor Relations Review 60, no. 1 (Oct., 2006): 23-44.

${ }^{57}$ Jackall and Levin, Worker Cooperatives in America, 22. 
therefore, even the least productive ones, during hard times would flagrantly violate not only the democratic, humanistic spirit of cooperativism but also one of its main economic functions in a society of employment insecurity.

In short, there is no question that cooperatives, even collectives, have potential for alleviating unemployment, and that this function is typically seen to take precedence over that of securing high wagesalthough the two are by no means always mutually exclusive.

Incentives, job satisfaction, productivity, and "the political effects of participation"

It should be obvious by now that a different set of incentives tends to operate in small cooperatives than in conventional businesses. Whereas the latter are typically structured primarily around the desire to make more money and get promotions faster than one's coworkers, the internal dynamics of the former have more to do with interpersonal relationships, the desire to feel good about one's work, the goal of maintaining a democratic workplace, and so on. Workers tend to have different expectations and want different kinds of rewards than they would hope for in a capitalist firm.

This is particularly true of collectives. As already stated, these are both the most numerous co-ops and, in general, the least remunerative. But, as with all things cooperative, this is partly by choice. People choose to remain in a collective, they accept low pay in part because they value other things more than money. Study after study demonstrates that collectivists want most of all to be in control of their work, and that they find nothing more miserable than working in a bureaucratic setting with a boss who orders them around. The following statements are illustrative: 
"You get a different feeling, working for yourself..." "You're working more hours but you get more enjoyment...it's your own." "There must be many people who, like us, have been driven half-insane by the dehumanizing straitjacket of the orthodox working world and yearned to be part of something better, more fulfilling." "There's some scope for personal creativity." "Not having someone who does not know the job telling you what to do..." "I believe now in my capability of being something. I've always felt impotent before about getting things done in the world. I believe I could start a business of my own if I wanted to. I've gotten practical knowledge and a sense of self as well that I couldn't conceive of before." "Every year I become a little more confident of myself as someone who counts." 58

Having control over work is not the only benefit. Closely related to it is the satisfaction of believing in one's work and lifestyle, being convinced of its moral worth. This is especially the case if the co-op exists in part to serve a broader social movement, whether it be through printing left-wing literature, as Red Sun Press does, or through promoting knowledge of whole foods, as some food cooperatives do. Such 'moral' orientations may serve the same function of raising self-esteem as does the opportunity to control the actual work process.

Collectivists are usually, though not always, liberal, educated, young, middle-class, and white. There are many exceptions, but on the whole this seems, for now, to be the demographic most attracted to the collectivist experience. "The [potentially] low salaries and erratic uncertain career paths [of collectivists] exclude, by selfselection, most minorities and all but a handful of those from

${ }^{58}$ Quoted in ibid., 124, and Cornforth, Developing Successful Worker Cooperatives, 100, 101. 
working-class origins." ${ }^{, 59}$ Many of these young cooperators move on to more conventional jobs after a few years in a collective, desiring more money, new outlets for their ambition, and perhaps less laborintensive, time-consuming work. But it is not uncommon to find middle-aged workers in collectives.

It's true that the sometimes-low pay can be considered a substantial cost, one of the most negative aspects of the collective experience. Tiredness due to long hours is also a common complaint, especially from workers who are very active in the business and feel that they are taking on an undue share of the burden. Resentment can arise toward less active members who are perceived as "free-riding." On the other hand, the more active one is, the more influence one has and respect one commands - as long as other workers do not perceive one as domineering or undemocratic. As mentioned above, collectives tend to be more susceptible to interpersonal conflict than conventional businesses are, due to their open, democratic, personalized structure.

None of these costs, however, is irremediable. Wages usually get higher, sometimes to union levels or above, after the co-op has been in business for a while and has accumulated experience and expertise; it is in the early stages or during difficult times that wages are lowest. The other problems can be mitigated simply by communicating with other members, airing grievances during meetings and strategizing about how to deal with them. Most cooperators report that meetings can be confrontational, stressful, sometimes traumatic, intensely personal, excessively long; but in principle it is through the mechanism of periodic general meetings that the pitfalls of cooperation can be overcome, or at least mitigated so that the benefits of cooperation decidedly outweigh the costs (as almost all cooperators report that they do). It must also be emphasized, again, that strong bonds frequently develop between cooperators, indeed partly because of the relatively intense and

59 Robert Jackall and Joyce Crain, "The Shape of the Small Worker Cooperative Movement," in Worker Cooperatives in America, 94. 
sometimes difficult nature of the work. Apologists for capitalism point to this existence of conflict as a flaw, but in fact it ought to be considered a strength. For one thing, it indicates that workers are personally committed to their work, unlike in many private enterprises. Overt conflict (when it exists) is also more psychologically healthy than suppressed conflict, and it is more ethical, in that it results from adults' treating each other as adults, with dignity. They confront their problems and try to solve them, which means they act as human beings rather than bureaucratic automatons who treat each other impersonally.

One source of "alienation" in conventional enterprises that cannot always be remedied in cooperatives is the intrinsically unpleasant nature of certain kinds of work. No matter what the social relations are, whether cooperative or competitive, sewing, for example, is not particularly fun. "It's hard work...you have to concentrate, you can't just gossip away and it can be boring," reports one worker. Printing may involve "toxic chemicals, noise, oil vapor, carcinogens." ${ }^{60}$ The industrial work of the old plywood co-ops is inherently monotonous: "It's like being a zombie... You're doing something that's basically unpleasant. Most jobs are monotony and repetition. It can drive you nuts... I go through times when I get so depressed." ${ }^{61}$ Even Karl Marx conceded that some kinds of work are inherently antithetical to freedom, the spontaneous creative expression of the human spirit:

...In fact, the realm of freedom actually begins only where labour which is determined by necessity and mundane considerations ceases; thus in the very nature of things it lies beyond the sphere of actual material production... [The realm of material production] remains a realm of necessity. Beyond it begins that development of human energy which is an end in itself, the true realm of freedom, which,

${ }^{60}$ Cornforth, Developing Successful Worker Cooperatives, 104.

${ }^{61}$ Quoted in Greenberg, Workplace Democracy, 82. 
however, can blossom forth only with this realm of necessity as its basis. The shortening of the working-day is its basic prerequisite. $^{62}$

Marx may even have exaggerated here the intrinsically alienating features of material work. But his broader point is correct: some activities will never, no matter how they're organized, be the sort of thing one chooses to do for their own sake. This is one of the reasons why some collectives practice job rotation.

A problem that may afflict collectives, and to an extent larger coops, but does not affect private enterprises is conflict over goals. Workers have to decide whether their main objective is to have high wages, to provide employment to as many people as possible, to provide a cheap service to political and community groups, to grow as a business and spawn new co-ops, or any other objective to which some members may be committed. The potential for strife here is great. Moreover, even if the members reach a consensus on how to prioritize objectives, there remain external constraints on cooperative goals and values, such as the need to be efficient and competitive against conventional businesses that may not have the same problems with capitalization as co-ops do. This necessity is less constraining the more "marginal" a cooperative is-for example if it serves a niche market where there is not much competition from other firms - but co-ops will always have to act like a capitalist business to some extent, just to stay afloat.

Actually, labor productivity is usually higher in cooperatives than in conventional enterprises, for obvious reasons. I will return to this issue in the section on larger cooperatives; suffice it to say for now that cooperators have greater incentives to be productive than typical employees do. For one thing, worker-owners can directly appropriate, or do as they want with, profits, whereas in capitalist firms profits usually go to outside investors. Thus, the connection between the success of the capitalist business and the employee's

${ }^{62}$ Marx, Capital, Vol. 3, Part VII, Ch. 48. 
personal gain is not as direct as it is in a co-op. Cooperators will also exert peer pressure on one another to perform well, and the relatively high camaraderie present in the work process will have a productivity-boosting effect. The work itself, as stated above, is more intrinsically rewarding and self-actualizing, especially in collectives, and the democratic environment, which allows access to information that would be withheld from conventional employees, is empowering. Cooperators are not always more productive than regular employees, but the incentives for high productivity are great.

Another argument sometimes made by leftists in favor of cooperativism is that it encourages class-consciousness, participation in politics and social movements, and in general fosters a "proactive" transformation of individual character. The hope is that cooperators will carry over their work practices (insofar as they involve democratic engagement) into the outside world, and that the co-op itself might join and support progressive movements. Unfortunately, the data on this are mixed. With regard to collectives, few generalizations can safely be made. It's true that most collectivists report that their experiences have raised their self-esteemespecially if they used to work at a traditional company-and they certainly enjoy work more than most employees do. It has not been conclusively established, however, that membership in a collective inherently raises political consciousness or encourages political activity. While it is likely that collectivists have had a higher rate of political participation than the population as a whole, that is partly because the sort of people who join small co-ops are more likely to have a liberal activist's temperament and values. Also, many such co-ops are explicitly political, such as left-wing printing presses and bookstores. Even food cooperatives are relatively political, since the distribution of food is a political issue. But cooperatives are also businesses, and as such might choose not to join a movement or even act contrary to progressive interests, for instance by negotiating deals with employers that are injurious to the latter's employees. American history is replete with examples of cooperatives alienating the local labor movement. Co-ops also might be loath to offend their customers by taking overtly political stances. 
So, individually and collectively cooperators as such might be prone to progressive activism (see below) but are not so in any stunning way. It seems as though they should be because their workplaces are relatively egalitarian and empowering, but one must remember the lesson of Marxism: social dynamics are holistic, such that individuals and institutions are molded by pressures emanating from everywhere in the society. The social structure as a whole conditions entities to behave in certain ways, and in a sense it reproduces itself. ${ }^{63}$ Thus, the facts that co-ops have to survive in a capitalist context and that cooperators themselves have been shaped by broader patterns in the society tend to undermine whatever anticapitalist and politically participatory implications there are in cooperative production relations. On the other hand, the latter's political potential becomes more potent the more cooperatives colonize a given area, building up their own culture, and the more they network with each other. For then they might develop political agendas, lobby together for favorable legislation, link up with other movements in similar structural locations and with similar interests and ideals. Such networking is arguably the most important element in any attempt to make society a more humane place.

${ }^{63}$ Louis Althusser called this "structural causation," different from other kinds of causality. It is an obscure notion but a necessary one, which is operative not only in society but in nature (albeit in a different way, a more deterministic way). Althusser thought that Spinoza was the first Western thinker to grasp the importance of structural causation, the first to pose the question of how the elements of a whole can be conditioned or determined by the whole itself (which, in Spinoza's pantheistic system, was the entire universe, which he called God). See Althusser and Étienne Balibar, Reading Capital (London: New Left Books, 1970), especially 182-193, and Alison Assiter, "Althusser and Structuralism," The British Journal of Sociology 35, no. 2 (June, 1984): 272-296. Structural causation is closely related to the difficult ideas in contemporary philosophy of "downward causation" and "emergence." 


\section{Medium-sized and larger cooperatives}

\section{Organizational structure}

In general, the larger an organization is, the more complex and less directly-democratic its structure is. Indeed, it almost necessarily becomes more bureaucratic and hierarchical, because in order to function smoothly some specialization of roles is required. A business with 100 employees has to have a more differentiated structure than a business with 15 employees; for example, it has to process much more information, of different kinds. With specialization and bureaucratization comes an element of hierarchy. There has to be a central organ that collects all the information and uses it to make decisions about the organization's future and its relations with the outside world. Theoretically the entire body of workers could make these decisions collectively-perhaps everyone could receive a packet of information about the firm's operations, study it for a week or two, and then congregate in a general meeting-but certain constraints make this unrealistic. As stated above, the time constraints may be prohibitive. Also, the information that has to be digested may be so technical that most workers are unable or unwilling to absorb it, preferring to leave it to specialists who have been trained in the particular topic. Or they may simply be apathetic and too exhausted at the end of the day to devote hours to administrative matters. ${ }^{64}$

For many reasons, therefore, some of which are not necessarily related to the nature of capitalist social structures, it may be necessary to have specialized professionals advising a board of directors. In a large cooperative, direct democracy will be the exception, representative democracy the rule. The board of directors will have to appoint managers - or they can be directly elected by the workforce, as the board of directors is - to ensure the smooth daily coordination of the business. Workers do monitor each other in many

${ }^{64}$ See, e.g., Kasmir, The Myth of Mondragon, 136-138. 
large co-ops, but it is not hard to imagine situations in which at least a few designated "superintendents" of some sort are necessary (and perhaps would be so even in a more egalitarian economy than the present).

The now-defunct plywood cooperatives of the Pacific Northwest, whose history will be discussed in the next chapter, illustrate these points. In the early 1980 s there were 11 such co-ops in Washington and Oregon, each owned by between 100 and 300 workers. Christopher Gunn summarizes their governance structure as follows:

Owner-members elect their board of directors, and the firm's general manager is appointed by that board. The board and the manager administer the routine operations of the co-op; policy decisions are made on a one-person, onevote basis by all owner-members in semiannual or quarterly general meetings [where "there are discussions about everything from the manager's performance to capitalinvestment decisions"]. Major decisions are discussed extensively by owner-members, who have full access to information concerning the co-op's operation. The core of production workers in these co-ops essentially hires and fires its manager. ${ }^{65}$

There is an element of hierarchy in production and decisionmaking on the shop-floor, but much less so than in comparable capitalist firms. The word "hierarchy" in fact is a bit misleading: plywood worker-owners take their "supervisor" much less seriously than in conventional mills because his continued employment depends on their goodwill, and it is very rare that he will try to fire one of them. (Sometimes he is an outsider who has been hired, sometimes a worker-owner himself.) There are also few supervisors in plywood co-ops, maybe one or two per shift, whereas in a private

${ }^{65}$ Christopher Eaton Gunn, Workers' Self-Management in the United States (Ithaca, NY: Cornell University Press, 1984), 100, 109. 
enterprise there have to be six or seven because the workers have less of an incentive to work efficiently. The co-op supervisor tends not to bother the workers but concentrates on "broader, plant-wide issues having to do with the flow of materials and machine-usage." 66

Plywood cooperators, who often have semiskilled jobs that can easily be rotated, frequently organize informal job rotations to alleviate monotony or for some other reason. This is not done in conventional mills, where "jobs are assigned through precise and formal agreements made between management and the union." 67 Cooperators also initiate innovations in work procedures and have more flexibility in their tasks than at conventional mills.

Thus, while considerations of efficiency dictate that the consensual, spontaneous, "self-actualizing" form of collectives be limited in larger co-ops, it can still exist to a much greater degree than at private enterprises. One should not think, incidentally, that this presence of democracy constrains efficiency, that it signifies a compromise between freedom and productivity. Quite the contrary. The above description should already have helped dispel that impression; moreover, as I mentioned earlier, bureaucracy not tempered by democracy can be extremely inefficient, whether it's in a government or a business. Therefore, to compromise between participation and hierarchy in a large organization is in fact to establish the greatest possible efficiency. I'll return to this point below.

Companies in the Mondragon Cooperative Corporation, which have hundreds or thousands of workers, have a more complex governance structure than the plywood co-ops. The general assembly of all worker-members in each company meets at least annually to elect a governing council (similar to a board of directors) and to approve company plans and policies. Members of the governing council, who themselves are workers, have four-year terms; they are not paid for their council responsibilities but receive their regular

\footnotetext{
${ }^{66}$ Edward Greenberg, "Producer Cooperatives and Democratic Theory: The Case of the Plywood Firms," in Worker Cooperatives in America, 196.

${ }^{67}$ Ibid., 191.
} 
salaries. The council appoints and can remove the CEO and must approve his choices for senior executives; it meets once or twice a month to monitor the management team's and the company's performance. There is also a "Social Council" that meets monthly, composed of representatives elected annually; its role is vaguely similar to that of a union, though it is supposed to be more cooperative than confrontational vis-à-vis the governing council and the management team. It serves as the voice of all the workers, communicating with management on such issues as working conditions, wages, and health and safety. This structure has worked for decades. ${ }^{68}$

Each cooperative in Mondragon has its own workplace structure, though there are similarities and tendencies that most of them share. The firm called Irizar, which manufactures products for transportation, from luxury coaches to city buses, exemplifies these tendencies. To encourage innovation and the diffusion of knowledge, there are no bosses or departments in Irizar. Rather, it has a flat organizational structure based on work teams with a high degree of autonomy. (One study remarks that they "set their own targets, establish their own work schedules, [and] organize the work process as they see fit.") The teams also work with each other, so that knowledge is transmitted efficiently. Participation occurs also in the general assembly, which meets three times a year rather than the single annual meeting common in other Mondragon firms. Its subsidiaries in other countries have at least two general assemblies a year, where they approve the company's strategic plan, investments,

${ }^{68}$ William Foote Whyte and Kathleen King Whyte, Making Mondragon: The Growth and Dynamics of the Worker Cooperative Complex (Ithaca, NY: ILR Press, 1988), 35-41; and Fred Freundlich, "The Mondragon Cooperative Corporation: An Introduction," Ownership Associates, May 22, 1998, http://www.ownershipassociates.com/mcc-intro.shtm (accessed April 10, 2010). 
etc. These participatory structures have enabled Irizar to surpass its competitors in profitability and market share. ${ }^{69}$

The cooperative in south India called Kerala Dinesh Beedi (KDB), which has had great success since its inception in the late $1960 \mathrm{~s}$, is worth describing because of its unusual characteristics. First of all, it is very large: at times having had over 35,000 workermembers, it currently has about 9000. It grew out of a conflict between the employees and owners of a private company, when the owners laid off 12,000 beedi workers in the state of Kerala. ${ }^{70}$ A leftwing government had come to power in Kerala in 1967 and was committed to implementing recent national legislation that would regulate and improve the deplorable conditions of the beedi industry. Beedi employers were not happy with these developments; they wanted to continue using child labor and also institute a domestic "putting-out" system to fragment the workers, whose unions had been active in radical social movements for decades and were troublesome to the employers. One of the latter essentially declared war on the unions and the new leftist government: not only did it threaten to relocate to a different state if the government enforced the law, but it laid off 12,000 employees. ${ }^{71}$

A months-long crisis ensued, until the government and the unions decided to create a new cooperative to employ the 12,000 laid-off workers. Cooperatives had been created before in Kerala, but not nearly on this scale. The workers could not afford to put up much

${ }^{69}$ Greg MacLeod and Darryl Reed, "Mondragon's Response to the Challenges of Globalization: A Multi-Localization Strategy," in Cooperatives in a Global Economy: The Challenges of Co-operation Across Borders, eds. Darryl Reed and J. J. McMurtry (Newcastle: Cambridge Scholars Publishing, 2009), 127-132. Irizar recently left Mondragon, but it has kept its cooperative structure.

${ }^{70}$ Beedis are a kind of primitive, hand-rolled cigarette, very popular in India.

${ }^{71}$ T. M. Thomas Isaac, Democracy at Work in an Indian Industrial Cooperative: The Story of Kerala Dinesh Beedi (Ithaca: Cornell University Press, 1998), chapters 2 and 3. 
capital, so the government lent them millions of rupees, in addition to helping the trade unions accomplish the monumental organizational tasks. Government officials even joined the board of directors. What is amazing is that despite all this political involvement, the government soon "withdrew from any active role in the running of the cooperative." $" 72$ Even the endemic Indian problems of corruption did not arise, since the government was desperate for the cooperative to succeed.

One study summarizes the structure of KDB:

$\mathrm{KDB}$ is a federation of twenty-two "primary cooperatives." Each of the primary cooperatives has six to fourteen shop floors. At each, there are generally between 75 and 125 beedi-rollers. Production takes place at the shop floor. Every worker directly participates, informally and continually, in the decisions about work arrangements at his or her shop floor. Each shop floor has a formal, general body meeting only about once every six months. At the general body meeting of each group of shop-floor workers (seventyfive to one hundred twenty-five people) everyone participates. These meetings are the fora for discussing complaints about conditions of work, disputes with supervisors, and problems with the behavior or productivity of individual workers. Every shop floor also has a "factory committee" that does the day-to-day supervision and management of the floor. This involves deciding on matters such as ventilation, entertainment, and break times. ${ }^{73}$

Each primary cooperative has a board of directors elected by the members, which supervises the purchase of raw materials from, and the sale of finished beedis to, the "central cooperative," which is the point of contact between KDB and the outside world. Its decisions

${ }^{72}$ G. Mitu Gulati et al., "When a Worker's Cooperative Works: The Case of Kerala Dinesh Beedi," UCLA Law Review, no. 5 (June, 2002): 22.

${ }^{73}$ Ibid., 25. 
are a function of market demand; it is in charge of quality control, pricing, marketing strategy, diversification, the overall structure of wages and benefits, etc. The central board of directors is elected by the primary cooperatives' boards of directors. Workers participate regularly in meetings with their unions, which then negotiate wages and benefits with the central cooperative. There are annual meetings of representatives of all the primary cooperatives.

Shop-floor supervisors cannot hire, fire, transfer, or fine their worker-bosses, but they have power nonetheless. They are usually senior workers themselves; they're promoted to their new position by the primary cooperative's board of directors. The supervisors are supervised, in turn, by foremen who have been hired by the central cooperative. The main function of a supervisor is to help train workers whose productivity is low or whose beedis are of low quality, but he is also responsible for enforcing workplace discipline and, of course, for monitoring individuals' productivity. Various positive incentives have been devised to encourage productivity, and as we'll see, they have been quite effective.

In short, while every worker cooperative has its own distinctive structure, the egalitarian and participatory tendencies I've described characterize all of them to some degree. These are the most important features distinguishing them from capitalist enterprises.

\section{Wages and employment}

The pay scales at large cooperatives are either identical to those at collectives or somewhat more unequal due to competitive pressures. The plywood co-ops paid all their members equally, the major exception being the general manager, who was usually a hired outsider and received a higher salary than members. ${ }^{74}$ In the conventional plywood mills, by contrast, the wages of the highestpaid workers and the lowest-paid differed by a factor of about 2.5 . $^{75}$

\footnotetext{
${ }^{74}$ Gunn, Workers' Self-Management, 115.

${ }^{75}$ Dow, Governing the Firm, 53.
} 
At Mondragon, until the 1980s the differential between the highest- and lowest-paid workers was fixed at 3:1. In recent years, with the pressures of globalization and the need to attract skilled managers who could receive much more money in private enterprises, some positions have been raised to a $6: 1$ ratio, while the CEO of the entire Mondragon corporation earns nine times more than the lowest-paid worker. ${ }^{76}$

The fact that cooperative pay-scales are always relatively egalitarian is intuitive and uncontested. Less clear is whether ordinary workers in co-ops tend to be paid more or less than their counterparts in capitalist firms. It is known that, generally speaking, management is paid less than in capitalist businesses: this can be inferred from the smaller pay scale in co-ops. But the data on the wages of the average worker are less clear-cut. As we saw above, some collectives give their members higher pay and better benefits than in comparable private enterprises, while other collectives are unable to do so, especially if their capitalist competitors are unionized. Larger co-ops more regularly offer higher compensation, in many cases much higher than at comparable capitalist businesses - but, again, only for low-level or, sometimes, mid-level workers. David Herrera reports that "wages at Mondragon, as compared to similar jobs at local industries, are 30 percent or less at the management levels and equivalent at the middle management, technical and professional levels. As a result, Mondragon workerowners at the lower wage-levels earn an average of 13 percent higher wages than workers in similar businesses."

Kerala Dinesh Beedi provides an even better example of high wages: workers earn over three times as much as those in other firms (including health benefits, maternity benefits, pensions, and paid holidays). While most beedi workers slave away in "small and dingy work sites that lack proper bathroom facilities and pose health

\footnotetext{
${ }^{76}$ McNamara, "Payment Solidarity: Looking Deeper at the Mondragon Principles."

${ }^{77}$ David Herrera, "Mondragon: A For-Profit Organization that Embodies Catholic Social Thought" (2004), at http://www.scribd.com.
} 
hazards because of the way the tobacco is kept," KDB members have work sites that are spacious, clean, well-ventilated, and even "have entertainment in the form of someone who reads stories or news articles to the workers as they are rolling beedis." Managers, on the other hand, earn only about as much as the beedi workers themselves, whereas in a capitalist firm of comparable size they would probably make 30 or 40 times that level, in addition to having luxurious perquisites not offered KDB's managers. ${ }^{78}$

Cooperative Care in Wisconsin, which provides care to the elderly, was able to give its 81 members in 2004 relatively high pay, workers' compensation, ten days' paid vacation, and 50 to 75 percent health insurance coverage, all only three years after beginning operations. ${ }^{79}$ Similarly, Cooperative Home Care Associates in the Bronx, New York, founded in 1985, offers its 1700 members "significantly better pay and working conditions than most home health aides." 80

How are cooperatives able to maintain high wages while competing successfully against conventional enterprises? The answer lies partly in their high productivity, which I'll discuss below. Also, greater size leads to greater capital accumulation than in collectives, which leads to more revenue in a self-reinforcing cycle. Collectives often just don't have enough capital to get the cycle started in a meaningful way - although, to repeat, when the annual distribution of profits and benefits is taken into account (in addition to wages), many collectivists do have a higher income than their conventional competitors.

As regards the trade-off in hard times between wages and employment, medium-sized and large cooperatives have the same

\footnotetext{
${ }^{78}$ G. Mitu Gulati et al., "When a Worker's Cooperative Works," 39, 40.

${ }^{79}$ Greg Lawless and Ann Reynolds, "Worker Cooperatives: Case Studies, Key Criteria and Best Practices," University of Wisconsin Center for Cooperatives, staff paper no. 3 (July, 2004), http://www.communitywealth.org/pdfs/articles-publications/coops/paper-lawless.pdf.

${ }^{80}$ Dan Bell, "Worker-Owners and Unions: Why Can't We Just Get Along?," Dollars \& Sense (2006), at http://www.dollarsandsense.org.
} 
priorities as collectives: they adjust pay rather than employment. The plywood mills, again, illustrate the point. A 1992 study compares the responses of three types of firms in the plywood sector-unionized, non-unionized, and co-ops - to adverse economic circumstances in 1980 , as contrasted with the expansionary year of 1972. It finds that

employment in the union mills and in the classical [nonunion] mills in 1980 averaged 83.6 percent and 51.3 percent of the 1972 values, respectively, whereas employment in the co-ops was 115.9 percent of the 1972 level; with respect to nominal average hourly earnings, earnings in the union mills more than doubled between 1972 and 1980, whereas earnings in the co-ops in 1980 were 183.8 percent of their 1972 levels. $^{81}$

Thus, employment shrank significantly in the conventional firms but actually grew in the co-op, while the earnings of the cooperative workers did not grow as fast as those of the union workers. This supports my earlier contention that cooperatives have even more potential for alleviating unemployment than for providing high incomes.

Incentives, job satisfaction, productivity, and the political effects of participation

Because sizable co-ops are usually less economically marginal, more "mainstream," than collectives, and the people who work in them are more ordinary demographically and have more conventional expectations for their jobs, competitive success and high compensation are relatively important incentives. High profitmargins are valued so that members can earn more and (perhaps) the business can expand and invest in new technology. After all, most of

${ }^{81}$ Ben Craig and John Pencavel, "The Behavior of Worker Cooperatives: The Plywood Companies of the Pacific Northwest," The American Economic Review 82, no. 5 (December, 1992): 1085-1105. 
these co-ops are founded solely to provide employment; the element of idealism or passion for a particular cause is rarely as significant as it is to many collectivists.

Owner-members of the plywood co-ops indicated in interviews that the reasons they joined the cooperatives were the potential for good income and job security. They have "individualistic, propertyholding motivations" that do not change as they experience the cooperative relations of production. ${ }^{82}$ This is in marked contrast to most collectivists, who have precisely the opposite motivations - the inherently political desire to "escape the rat race" and do something they believe in. One obvious reason for the difference is that the plywood cooperators have a working-class origin and have known long periods of unemployment. ${ }^{83}$ They think of their participation in a co-op as a financial investment: buy a share and get a secure job.

However, they quickly come to appreciate the control they have over their work. While they remain less "idealistic" than the average collectivist, their attitude certainly differs from that of the workforce in a conventional plant, which tends to suffer from a relative "deadening of the spirit, a sense of defeat, hopelessness, and abjectness." The participatory environment of the cooperative "fosters an extremely strong sense of collective responsibility and mutuality," which is antithetical to the structure of work in a conventional factory. As mentioned above, this sense of mutuality is manifested, e.g., in collective and self-supervision and the rather low number of designated supervisors. "Everybody pitches in and helps," remarks one worker; "the people stick together, that's the reason we've gone so far and production is so high, 'cause everybody works together." Some workers even profess to enjoy their work, despite its repetitive and mechanical nature: "There is a certain feeling to know that you own part of what you're working for... I've always gone to

\footnotetext{
${ }^{82}$ Gunn, Workers' Self-Management, 105.

${ }^{83}$ Greenberg, "Producer Cooperatives and Democratic Theory: The Case of the Plywood Firms," in Worker Cooperatives in America, 180.
} 
all the stockholders' meetings and...I enjoy it. I've never had so much fun! Hell, we run this operation all by ourselves." 84

One obvious supposed benefit of cooperatives is that there is less conflict between workers and managers than at conventional, hierarchical enterprises. Nearly all the data indicate that this is indeed the case. Consider, for example, a study published in 2001 that examines dispute resolution at a cooperative coal mine in Wales as compared to how it functioned when the mine was owned and operated by the British government, as it had been for years. In the early 1990s, with British Coal threatening to close it, 200 employees bought it and converted it into a worker cooperative. By law the company was required to have managers in charge of safety, finance, engineering and so on, but it hired only a third of the managers that had been employed by the government even though there was approximately the same number of miners. These managers retained significant power over the workers, but now their decisions could be overruled by the board of directors elected annually by the workforce.

When the mine was government-owned it was severely hierarchical and dispute resolution was confrontational: grievances, which cropped up continually, were resolved according to a rigid set of formal rules, and work stoppages instigated by either management or the union occurred frequently. Under cooperative ownership this all changed. Worker-owners were more flexible in upholding work rules, so that disputes were far less frequent. "Many current issues and conditions would have been formally contested under British Coal, warranting a grievance or other union action. Today, these potential disputes do not develop into grievances. Furthermore, these potential disputes are not...simply tolerated; instead, they are no longer seen as injurious experiences." ${ }^{85}$ Miners were now not unwilling to work overtime without extra pay, or, for example, they

${ }^{84}$ Ibid., 183.

${ }^{85}$ Elizabeth A. Hoffmann, "Confrontations and Compromise: Dispute Resolution at a Worker Cooperative Coal Mine," Law \& Social Inquiry 26, no. 3 (Summer, 2001): 568. 
would work at an undermanned site, whereas in the past that would have resulted in a grievance (because it entails extra work). In general, they were more willing to compromise, since their status as owners made them disinclined to stop work. Managers too were more easygoing and respectful, because power was more dispersed than in the past. One worker offers eloquent testimony:

Today, the manager will come out and talk to you. He very rarely goes through the pit without saying, you know, stopping and talking to everyone. Whereas before, the manager used to come down and he wouldn't talk to you. He'd probably tell somebody else who would tell you to do something. They felt they were some super-human! You know, we were down there and they were up at the top like. And it was all, "Do this!" They tell you rather than ask you.

Today, now, the manager comes down and he'll ask you, "Any chance you could?" You know? "Can you do me a favor?" Before it was, "Oh you get and do that!" And obviously the respect had gone from the men for the management under British Coal.

Now at the colliery the men have got a lot of respect for the manager, because, at the end of the day, he owns as much of the colliery as we do. We all have equal-share basis and he's in it for the same reason we are: to get the best out of the colliery. ${ }^{86}$

Admittedly, some research indicates worker discontent at certain large cooperatives, including conflict between management and the workforce. Mondragon, considered an exemplar of large-scale worker cooperation, has not been immune to this. For instance, in 1989, at a typical co-op with 250 worker-owners, members reported to a researcher that they most definitely did not think the firm was democratic. They referred to themselves as "working stiffs" and

${ }^{86}$ Ibid., 573. 
called the managers "bosses." "We are not different," they said, "from other businesses in any way." "It doesn't matter how equal we are in theory, in practice we are not." "What good does it do me that they call me a collaborator when they treat me like a subordinate... At least in a regular firm you can call the boss a son of a bitch." 87 Managers at this company considered relations between themselves and the workforce to be cooperative, respectful, and democratic; the workers, however, disagreed.

A study in the mid-1980s reported that Mondragon's supervisory structures were virtually identical to those at nearby conventional firms, and observed that "the necessity to compete in national and international markets leaves insufficient space to implement alternative manners of work organization on a large scale." 88 Moreover, in recent years there have been major organizational changes considered necessary to maintain international competitiveness, so that now pay-scales are less flat, management councils have more power, and non-cooperative subsidiaries are being acquired in China, Brazil, and other countries.

There is no question that the need to compete in a capitalist world forces large co-ops to compromise their principles. This has always been a criticism leveled at them by Marxists and other radicals. Nevertheless, it does not appear that they necessarily have to degenerate into semi-capitalist corporations, nor that they ever have the same adversarial relations between management and the workforce as conventional firms do. Even in the example mentioned above from Mondragon, the author of the study notes that relations are more harmonious in the co-op than in a comparable capitalist company. As long as most of the workers own the firm and participate in governance, and especially if efforts are made to instill a culture of cooperation at both the shop-floor level and the enterprise level, there will be meaningful differences between cooperative and conventional firms. These differences may even be

\footnotetext{
${ }^{87}$ Kasmir, The Myth of Mondragon, 152.

${ }^{88}$ See Dow, Governing the Firm, 62.
} 
strictly economic: the co-op will quite possibly be more productive than its capitalist counterparts, because of incentives and the diverting of resources away from unproductive supervision and the need to contain conflict (which is a constant imperative in the average capitalist business).

For example, I noted above that fewer supervisors were needed in the plywood cooperatives, and the worker-owners were unusually committed to the success of the enterprise. (The same was true of the cooperative mine just discussed.) This resulted in higher productivity-rates - measured by the physical volume of output per hour, the quality of the product, and economy of material input usethan in privately owned mills, as much as 50 percent higher. A relatively low amount of capital per worker was required, and the hourly return to workers was often 50 percent higher than union averages. $^{89}$

The case of Kerala Dinesh Beedi is even more impressive. Despite its competitors' significantly lower labor costs, it has been able to compete successfully for decades. How is this possible? One area of advantage is its far fewer managers and their relatively low compensation. But KDB's labor costs remain high even so. Another advantage is that there have been no major labor disputes in its history - a fact that is stunning in itself, since disputes are common and costly in the region as a whole. Also, as noted earlier, shop-floor conditions are very efficient, with workers monitoring each other and sharing information willingly. A particularly decisive strength is the uniformly high quality of KDB's beedis, which customers appreciate. Workers at other companies have an incentive to be hasty and careless in their beedi-rolling because they are paid on a piecework basis, and monitoring is difficult. KDB workers, who are happier, healthier, and better-paid, are more careful. ${ }^{90}$

Examples of such productivity could be multiplied. But that would merely provide further illustrations of the intuitively

${ }^{89}$ Gunn, Workers' Self-Management, 103.

${ }^{90}$ G. Mitu Gulati, "When a Worker's Cooperative Works," 40-44. 
reasonable point that labor will tend to be more productive in co-ops than in conventional businesses. One author concludes, on the basis of a meta-analysis of 43 previous studies, that (1) worker participation in decision-making in co-ops has a "small, positive, and statistically significant association with productivity, rejecting the traditional view that democratic management of the firm is associated with reduced efficiency"; (2) profit-sharing in cooperatives is very strongly associated with increased productivity, while the association is less pronounced in capitalist enterprises; (3) worker-ownership in co-ops has a small but statistically significant association with productivity, whereas in capitalist firms there is virtually no correlation (probably because employees typically own only a small proportion of assets). ${ }^{91}$ A study in 1994 found that "employee involvement programs are invariably positively associated with desirable outcomes (such as greater work effort and higher productivity), whereas measures of performance pay are less robustly associated with these outcomes." 92 More recent studies have concluded that there is often a gain in productivity with employee stock-ownership plans-again, a result compatible with the hypothesis that worker cooperatives will tend to have high labor productivity. ${ }^{93}$

A number of reasons can be thought of to explain these results, most of which have already been mentioned. Cooperatives have lower absentee rates and less worker turnover than their conventional competitors. (For instance, the annual rate of turnover in the Mondragon cooperatives in 1974 was two percent, while in comparable capitalist firms it was 14 percent.) ${ }^{94}$ Members show relatively high individual work effort, tending to act as their own

\footnotetext{
${ }^{91}$ Chris Doucouliagos, "Worker Participation and Productivity in LaborManaged and Participatory Capitalist Firms: A Meta-Analysis," Industrial and Labor Relations Review 49, no. 1 (October, 1995): 58-77.

${ }^{92}$ John Pencavel, Worker Participation: Lessons from the Worker Co-ops of the Pacific Northwest (New York: Russell Sage Foundation, 2001), 80.

${ }^{93}$ See, e.g., ibid., 81, 82.

${ }^{94}$ Jackall and Levin, Worker Cooperatives in America, 26, 27.
} 
supervisors, at least to a greater degree than employees do elsewhere. Job rotation, where it happens, enhances the attractiveness of the work. And there are greater incentives to help one another than in a competitive environment.

Does all this have implications for political consciousness and participation? It seems to, but less so than one might hope. I noted above that collectivists tend to be relatively politically conscious and active but that the reasons for this are not clear. The situation is even more ambiguous with regard to larger cooperatives. Edward Greenberg's conclusions about the plywood industry are illustrative. He addresses four claims made by leftists: "workplace democracy encourages participation in other social institutions outside of the workplace; helps create citizens who are endowed with a sense of their own political efficacy; increases participation in normal political life; and creates a sense of community and cooperation as well as a commitment to the public interest." ${ }^{95}$ Few of his findings are encouraging.

For example, worker-owners were actually a little less likely to participate in organizations outside the workplace than conventional employees. This could be due to the fact that many of the latter belong to unions, unlike the former, which may foster political consciousness and activism. On the other hand, Greenberg finds that over time the cooperators did increase their participation in social institutions, though not to above the level of ordinary employees. They also didn't have any greater sense of political efficacy than regular workers. More encouragingly, members were significantly more politically involved than conventional workers and were more likely to increase their participation over time-but at the same time they were more likely to think that "Society is best off when each individual looks out for his own well-being and not the well-being of others," and in fact to agree with this statement more the longer they worked in a co-op. So their political participation was not necessarily a sign of public-spiritedness. Nor were they class-conscious in a

${ }^{95}$ Greenberg, Workplace Democracy, 119. 
good way: they were relatively likely to call themselves middle-class rather than working-class, and a relatively high proportion identified themselves as Republican. (This was during the Reagan years.) ${ }^{96}$ Greenberg concludes:

Clearly...without powerful countervailing forces to the market mechanism, democratic, self-managed enterprises drift inexorably toward enterprise egoism and membership behavior as collective capitalists. Without a working-class party, a cooperative or egalitarian culture, a socialist ideology, a revolutionary movement, or a government committed to economic democracy, the logic of the market is determinative and blocks the larger promise of selfmanagement... ${ }^{97}$

Especially in a large cooperative, whose members are typically more concerned with having money and a secure job than collectivists are, the market mentality can prove stronger than the democratic, egalitarian, workers' social-movement mentality.

As always, there are many counterexamples. Equal Exchange, with about 100 members, is politically progressive, committed to such causes as Fair Trade. Inspired by Mondragon and the cooperatives of northern Italy, it has also begun donating a portion of its earnings to a fund for the development of new co-ops. ${ }^{98}$ Rainbow Grocery in San Francisco, owned by about 150 workers, likewise functions as a center of progressivism, in the tradition of many

\footnotetext{
${ }^{96}$ Ibid., 120-131, 137, 168.

${ }^{97}$ Ibid., 168. See also Edward Greenberg, "Spillovers from Cooperative and Democratic Workplaces: Have the Benefits Been Oversold?", http://www.colorado.edu/ibs/PEC/workplacechange/publications/democrac y/SpilloversFromCooperativeDemocraticWorkplace.pdf (accessed November 27, 2013).

${ }^{98}$ Camille Jensen, "Equal Exchange creating capital for new co-ops," Axiom News, September 25, 2009, http://www.axiomnews.ca/NewsArchives/2009 (accessed May 25, 2010).
} 
natural-food stores. Kerala Dinesh Beedi has a long history of radical political activism going back to even before its formation. The region of Kerala has bred left-wing social movements since early in the twentieth century; KDB's labor unions are militantly Marxist.

Such examples support Greenberg's point that progressive political activism, while not guaranteed by a cooperative workplace, is not only compatible with it but potentially encouraged by it as long as the business either maintains ties with cooperative institutions or is run by workers committed to radical ideologies. Unionization of employees in conventional companies likewise fosters political consciousness and action; there is no particular reason, therefore, why cooperatives cannot affiliate with unions and assist them politically, and vice versa. This has been common practice in Europe for a long time, was so in the United States for much of the nineteenth century, and, as we'll see later, is starting to become so again.

\section{Other issues}

I have yet to address a number of important matters in relation to cooperatives of all sizes. First, in what sectors is it most common to find them? All the research indicates that it is the labor-intensive, service areas of the economy. Food stores, bookstores, print shops, restaurants, repair services-all risky areas for small business. Historically, U.S. cooperatives have had "a strong craft orientation, with fields of activity including metal foundries, barrel-making, shingle-making, and plywood." 99 Many Western European cooperatives operate in construction and certain labor-intensive branches of manufacturing. Some Mondragon and Italian cooperatives, however, are very capital-intensive, which is possible because of the networks they have established with each other. Also, cooperatives are relatively common in the somewhat capitalintensive industry of transportation - a number of taxi companies

${ }^{99}$ Dow, Governing the Firm, 49. 
have been cooperatives - which is probably because the physical assets needed (such as vehicles) can easily be resold at close to their purchase price if the business fails, so that there is relatively little risk in lending money to the co-op. ${ }^{100}$

The main problem, then, is that most cooperators or would-be cooperators have limited access to financial capital. Why is that? Sometimes they decide to seek capital only from their members; in this case, the reason for undercapitalization is self-evident. One reason they might shun bank loans is if banks charge high interestrates. Sometimes banks will require that each member provide collateral to guarantee the loan, a risk that some workers might not be willing to undertake. ${ }^{101}$ Two reasons why traditional lenders might be reluctant to lend to worker-run enterprises are

because of heightened levels of (a) moral hazard and (b) transactions costs. The moral hazard argument is that lenders bear most of the risk of failure in situations in which workers can easily move to new jobs in the event of the firm's failure. As for the higher transactions costs, the argument is simply that it is easier and quicker to deal with a single borrower (or the borrower's delegate who has authority) than to deal with a group that has to use a democratic process to make decisions. ${ }^{102}$

Overseeing the activities of an enterprise with a small number of decision-makers is easier than if every worker is a director and owner. Even the initial loan is then relatively difficult to arrange: the bank has to deal with the elected board of directors, drawn from the

\footnotetext{
${ }^{100}$ Henry Hansmann, "When Does Worker Ownership Work? ESOPs, Law Firms, Codetermination, and Economic Democracy," The Yale Law Journal 99, no. 8 (June, 1990): 1771.

101 John W. Lawrence, "Raising Capital for Worker Cooperatives," http://www.communitywealth.org/ pdfs/articles-publications/coops/articlelawrence.pdf (accessed May 18, 2010).

${ }^{102}$ G. Mitu Gulati, "When a Worker's Cooperative Works," 12.
} 
ranks of the workers, who have often had no experience arranging bank loans. Sometimes "the bank must ultimately go to a shareholders' meeting and explain the terms of a loan to them, an unfamiliar experience for the lending officer and not always a pleasant one." Apart from this, "the bank's worst fears are that the co-op will distribute the loan among its workers and then declare bankruptcy." It's not surprising, therefore, that banks might attach onerous conditions to loans. ${ }^{103}$

An additional advantage, from the perspective of lenders, of undemocratic firms is that it is easier for the lender to influence the policies of such firms, for instance by preventing them from undertaking excessively risky or excessively conservative projects. One author remarks that with cooperatives "there is no guarantee of a single owner or officer who always represents the workers, given the democratic management. As a result, the financial community cannot obtain the leverage over cooperatives seeking to borrow that they can over capitalist firms." 104

Equity financing, on the other hand, is unappealing to cooperators because it may mean relinquishing control to outside investors, which is a distinctly capitalist practice. Investors are not likely to buy non-voting shares; they will probably require representation on the board of directors because otherwise their money could potentially be expropriated. "For example, if the directors of the firm were workers, they might embezzle equity funds, refrain from paying dividends in order to raise wages, or dissipate resources on projects of dubious value." 105 In any case, the very idea of even partial outside ownership is contrary to the cooperative ethos.

A general reason for traditional institutions' reluctance to lend to cooperatives, and indeed for the rarity of cooperatives whether related to the difficulty of securing capital or not, is simply that a society's history, culture, and ideologies might be hostile to the "co-

${ }^{103}$ Pencavel, Worker Participation, 38.

${ }^{104}$ Dow, Governing the Firm, 187.

${ }^{105}$ Ibid., 188. 
op" idea. Needless to say, this is the case in most industrialized countries, especially the United States. The very notion of a workers' cooperative might be viscerally unappealing and mysterious to bank officials, as it is to people of many walks of life. Stereotypes about inefficiency, unprofitability, inexperience, incompetence, and anticapitalism might dispose officials to reject out of hand appeals for financial assistance from co-ops. Similarly, such cultural preconceptions may be an element in the widespread reluctance on the part of working people to try to start a cooperative. They simply have a "visceral aversion" to, and unfamiliarity with, the ideawhich is also surely a function of the rarity of co-ops itself. Their rarity reinforces itself, in that it fosters a general ignorance of co-ops and the perception that they're risky endeavors. Additionally, insofar as an anti-democratic passivity, a civic fragmentedness, a halfconscious sense of collective disempowerment, and a diffuse interpersonal alienation saturate society, this militates against initiating cooperative projects. It is simply taken for granted among many people that such things cannot be done. And they are assumed to require sophisticated entrepreneurial instincts. In most places, the cooperative idea is not even in the public consciousness; it has barely been heard of.

Business propaganda has done its job well. ${ }^{106}$ But propaganda can be fought with propaganda. In fact, this is one of the most important things that activists can do, this elevation of cooperativism into the public consciousness. The more that people hear about it, know about it, learn of its successes and potentials, the more they'll be open to it rather than instinctively thinking it's "foreign," "socialist," "idealistic," or "hippyish." If successful cooperatives advertise their business form, that in itself performs a useful service for the movement. It cannot be overemphasized that the most important thing is to create a climate in which it is considered normal

${ }^{106}$ On the historical significance of business's crusade against the American left, see Patricia Cayo Sexton, The War on Labor and the Left: Understanding America's Unique Conservatism (Boulder, CO: Westview Press, Inc., 1991). 
to try to form a co-op, in which that is seen as a perfectly legitimate and predictable option for a group of intelligent and capable unemployed workers. Lenders themselves will become less skeptical of the business form as it seeps into the culture's consciousness.

It's true that people sharing a common culture or ethnicity, especially if they have emigrated to or live together in a diverse society, are more likely to start cooperatives. It was the Basques of northern Spain who started Mondragon, at a time when they were fiercely antagonistic toward Spanish (Francoist) society. The plywood co-ops were organized by Scandinavians in a community that benefited from high levels of trust. This theme of "cultural homogeneity" supports the hypothesis mentioned earlier that heterogeneity is not conducive to the formation and success of worker cooperatives. A heterogeneous co-op may succeed, but insofar as its heterogeneity undermines levels of trust, it threatens the co-op's survival. Ultimately, though, the most important precondition, particularly in small cooperatives, seems to be that individuals have a democratic attitude, commitment to the project, and some degree of interpersonal skills.

One obstacle to forming a co-op is the challenge of gathering a group of interested, capable, and like-minded people, people interested in starting the same kind of business, who can work well together and have enough information and initiative to do the difficult preliminary work. A single entrepreneur is unlikely to want his business to be a cooperative, since that would reduce his revenue and control. Hopeful cooperators will probably be workers who place a high value on job security or people committed to cooperation for ideological reasons. But such people are not likely to have a great deal of money to invest in a business, and they will be wary of putting thousands of dollars into one venture. Regular investors, of course, diversify their wealth for precisely this reason, this aversion to risk. It would seem, then, that risk-tolerant people 
would be most interested in forming a co-op-and such people are relatively rare. ${ }^{107}$

Employee buyouts of capitalist enterprises are not very common either. They usually happen, if at all, only when a company is in financial straits and workers want to save their jobs. One possible reason they're somewhat rare even in the case of failing firms is that they are more likely to occur if the employees are unionized, and unionization rates are low in the United States. Buyouts require a lot of work from a few leaders. Also, workers might not be able to agree among themselves on the many decisions that have to be made, some preferring a cooperative and others control by outside investors. When takeovers do occur, often the company is in such bad shape that even in a restructured form it fails within a few years. ${ }^{108}$

All these considerations are reasons why the formation rate of worker cooperatives is low. And this is the biggest problem for cooperatives, this low rate of formation. But once they do form, other problems can arise. A commonly cited one is that cooperators may lack business experience and know-how. Many of the co-ops formed in the 1960s and 1970s failed because they were started by youthful idealists who cared little about the technical details of running a business. ${ }^{109}$ They ignored accounting problems until it was too late. Even if the workers are competent, it might be difficult to attract managers or specialists if they are needed, since the pay is likely to be low. Another pitfall is that the stress and the personal intensity of work in cooperatives, especially collectives, might prove too much. People might find that they cannot work together or prefer an ordinary, possibly less stressful job, and the collective may dissolve.

${ }^{107}$ Pencavel, Worker Participation, 44.

${ }^{108}$ Dow, Governing the Firm, 218-221.

${ }^{109}$ Daniel Zwerdling, "The Uncertain Revival of Food Cooperatives," in Co-ops, Communes \& Collectives: Experiments in Social Change in the 1960s and 1970s, eds. John Case and Rosemary Taylor (New York: Pantheon Books, 1979), 102, 103. 
The severity of these problems is debatable-for example, Beatrice Webb was wrong to think that cooperatives will inevitably suffer from poor management because of an inability to attract skilled professionals ${ }^{110}$ - but other commonly cited hazards are in practice even less problematic. It doesn't appear to be widely true that democratic decision-making leads to great inefficiencies; on the contrary, I have argued that it can promote high productivity and work-discipline, and in those cases when direct democracy is impracticable it is easy to substitute representative democracy. Nor is it true that worker-owners tend to shirk or that monitoring is difficult; more often, the opposite is the case. ${ }^{111}$

On the other hand, the possibility of degeneration into a capitalist enterprise is real. Ironically, this can result from the coop's success. If the business wants to expand it might choose to hire labor rather than admit new members, because, under certain legal structures, if it adds new shares (each of which is to be bought by a new member) that reduces the value of the current members' shares. Ultimately, then, the co-op might end up having more wage-laborers than members. As we'll see in the next chapter, some of the plywood cooperatives degenerated in this way. Others, and many co-ops in the nineteenth century, degenerated by being sold to outside investors. That is, as "members approach[ed] retirement age and [became] more interested in wealth maximization than working conditions or other consumption benefits derived from firm membership," 112 each member would sometimes sell his valuable share to an investor (because it was too expensive for less wealthy prospective workers to buy). Or, in some cases, the members collectively sold the whole business to investors.

The possibility of degeneration diminishes if the co-op uses the proper legal structure. The best structure is that of the Mondragon

\footnotetext{
${ }^{110}$ Cornforth, Developing Successful Worker Cooperatives, 91.

${ }^{111}$ See, e.g., Will Bartlett et al., "Labor-Managed Cooperatives and Private Firms in North Central Italy: An Empirical Comparison," ILR Review 46, no. 1 (1992): 103-118.

${ }^{112}$ Dow, Governing the Firm, 225.
} 
companies, which do not allow workers to own a tradable share of equity. Instead, in addition to their wages they each have an internal capital account the value of which depends on the business's performance and on the number of hours the member works. A new member has to pay a large entrance fee, most of which is credited to his internal account. He receives interest at the end of every fiscal year, but he cannot withdraw the annually accumulating principal from his account until retirement. Almost all profits are divided between these individual accounts and a collective account that helps ensure the company's survival. No buying or selling of shares takes place in this scheme, so it's difficult for the firm to lose its workercontrolled status. Not until 1982, however, did the internal-capitalaccounts legal structure exist in the United States (and then only in Massachusetts); prior to that, worker cooperatives had to make convoluted use of other categories, which sometimes made them vulnerable to degeneration. ${ }^{113}$

In any case, the survival rates of contemporary cooperatives put the lie to traditional theories of cooperatives' unsustainability, for they appear to have higher rates of survival than conventional firms. During the 1970s and early 1980s, the death rate for co-ops in France (due either to dissolution or to conversion into a capitalist firm) was 6.9 percent; the comparable rate for capitalist competitors was 10 percent. A study in 1989 found much higher failure rates for capitalist companies than cooperatives in North America. ${ }^{114}$ A study

113 David Ellerman, "Workers' Cooperatives: The Question of Legal Structure," in Worker Cooperatives in America, 268-273. Even now, most states do not have worker-cooperative statutes. From early in the twentieth century cooperative corporation statutes have existed, but these were usually designed for farmer cooperatives and are "poorly drafted and outdated," so it was and is not particularly advantageous for worker co-ops to incorporate under them. David Ellerman, "What Is a Worker Cooperative?", in Beyond the Market and the State: New Directions in Community Development, eds. Severyn Bruyn and James Meehan (Philadelphia: Temple University Press, 1987), 240, 241.

${ }^{114}$ Dow, Governing the Firm, 226, 227. 
conducted by Quebec's Ministry of Industry and Commerce in 1999 concluded that "Co-op startups are twice as likely to celebrate their $10^{\text {th }}$ birthday as conventionally owned private businesses." 115 A later study by the same organization found that "More than 6 out of 10 cooperatives survive more than five years, as compared to almost 4 businesses out of 10 for the private sector in Québec and in Canada in general. More than 4 out of 10 cooperatives survive more than 10 years, compared to 2 businesses out of 10 for the private sector." $" 116$ These data sufficiently demonstrate the viability of cooperatives.

Indeed, their viability tends to be proportional to their cooperativeness:

Broadly speaking, it is those clusters of producer cooperatives with the most cooperative features...that have the longest life, the best economic performance, and the best record of maintaining a cooperative structure over time... A great number of cooperatives succumb to the demands for efficiency by progressively negating their cooperative character. The historical record suggests that in the end these firms will end up with neither cooperation nor efficiency. The key to successful, long-lived cooperatives seems to be precisely greater cooperation and a concomitant responsiveness to the economic and labor conditions of the marketplace. ${ }^{117}$

The reasons for cooperatives' success should be obvious by now, but they are worth reiterating: "The major basis for cooperative

${ }^{115}$ Luc Labelle, "Development of Cooperatives and Employee Ownership, Quebec-Style," Owners at Work (2001), at http://dept.kent.edu/ (accessed May 24, 2010).

${ }^{116}$ Quoted in Johnston Birchall and Lou Hammond Kettilson, "Resilience of the Cooperative Business Model in Times of Crisis" (Geneva: International Labor Office, 2009), 29, 30.

117 Jones, "American Producer Cooperatives and Employee-Owned Firms," in Worker Cooperatives in America, 52. 
success...has been superior labor productivity. Studies comparing square-foot output have repeatedly shown higher physical volume of output per hour, and others... show higher quality of product and also economy of material use." "118 Hendrik Thomas concludes from an analysis of Mondragon that "Productivity and profitability are higher for cooperatives than for capitalist firms. It makes little difference whether the Mondragon group is compared with the largest 500 companies, or with small- or medium-scale industries; in both comparisons the Mondragon group is more productive and more profitable." 119 As we have seen, recent research has arrived at the same conclusions. It is a truism by now that worker participation tends to increase productivity and profitability.

Research conducted by Henk Thomas and Chris Logan corroborates these conclusions. "A frequent but unfounded criticism," they observe, "of self-managed firms is that workers prefer to enjoy a high take-home pay rather than to invest in their own enterprises. This has been proven invalid...in the Mondragon case... A comparison of gross investment figures shows that the cooperatives invest on average four times as much as private enterprises." After a detailed analysis they also conclude that "there can be no doubt that the [Mondragon] cooperatives have been more profitable than capitalist enterprises." ${ }^{120}$ Recent data indicate the same thing. ${ }^{121}$ One particularly successful company, Irizar, which was mentioned earlier, has been awarded prizes for being the most

${ }^{118}$ Katrina Berman, "A Cooperative Model for Worker Management," in The Performance of Labour-Managed Firms, ed. Frank Stephens (New York: St. Martin's Press, 1982), 80.

${ }^{119}$ Hendrik Thomas, "The Performance of the Mondragon Cooperatives in Spain," in Participatory and Self-Managed Firms: Evaluating Economic Performance, eds. Derek Jones and Jan Svejnar (Lexington: Lexington Books, 1982), 149.

${ }^{120}$ Henk Thomas and Chris Logan, Mondragon: An Economic Analysis (Boston: George Allen \& Unwin, 1982), 103, 104, 109.

${ }^{121}$ Will Bartlett, "Labor-Managed Cooperatives," finds little difference between levels of investment in capitalist and cooperative firms in Italy. 
efficient company in its sector; in Spain it has ten competitors, but its market share is 40 percent. The same level of achievement is true of its subsidiaries, for instance in Mexico, where it had a 45 percent market share in 2005, six years after entering the market. An author comments that "the basis for this increased efficiency appears to be linked directly to the organization's unique participatory and democratic management structure." 122 A major reason for all these successes is Mondragon's federated structure: the group of cooperatives has its own supply of banking, education, and technical support services. The enormous funds of the central credit union, the Caja Laboral Popular, have likewise been crucial to Mondragon's expansion. It proves that if cooperatives have access to credit they are perfectly capable of being far more successful than private enterprises.

It's worth noting, incidentally, that most private corporations are fantastically inefficient, although their inefficiency is disguised by collusion with the government:

Contrary to their claims of efficiency, most large corporations...spend an inordinate portion of society's resources on advertising, executive perks and salaries, transportation and communications to far-flung corporate empires, and lobbying expenses. Most depend for their profits and survival on a complex regime of public subsidies, exemptions, and externalized costs, including the indirect subsidies they gain when allowed to pay less than a living wage, maintain substandard working conditions, market hazardous products, dump untreated wastes into the environment, and extract natural resources from public lands at below-market prices. Ralph Estes...estimates that in 1994 corporations extracted more than $\$ 2.6$ trillion a year in such subsidies in the United States alone-roughly five times

122 Greg MacLeod and Darryl Reed, "Mondragon's Response to the Challenges of Globalization: A Multi-Localization Strategy," in Cooperatives in a Global Economy, 131. 
their reported profits... It is one of the basic principles of efficient market function that the full costs of a product or service be borne by the seller and passed on to the buyer. Yet many corporations would be forced to close their doors or restructure if they had to bear the true full costs of their operations. $^{123}$

Americans sometimes think of large size almost as an end in itself, or at least as necessary for economic efficiency. But this is not always the case. In some industries, economies of scale do exist. But large size tends to entail bureaucratic inefficiencies, environmental destruction, allocative inequalities, political corruption, in general significant negative externalities. ${ }^{124}$ Consider, by contrast, the Emilia-Romagna region of northern Italy, "widely recognized as one of the world's leading examples of a successful cooperative economy, with [40 percent] of the region's GDP deriving from cooperative enterprises." 125 The region of four million people, one of the richest and most developed areas in Europe despite its poverty only a few decades ago, has between 10,000 and 20,000 cooperatives

${ }^{123}$ The International Forum on Globalization, Alternatives to Economic Globalization: A Better World Is Possible (San Francisco: Berrett-Koehler Publishers, 2002), 142. See also Ralph Nader, The Ralph Nader Reader (New York: Seven Stories Press, 2000), 147-194.

${ }^{124}$ William Greider points out also that "Above a certain size, getting bigger and bigger does not deliver new economies of scale; it simply walls off the threat of innovative competition. Companies use their size to guard their turf against intruders and, because they have greater financial resources and technological and marketing skills, they can literally smother the new guys who come along with a better idea." Therefore, the "success" of gigantic corporations like ExxonMobil and Microsoft does not necessarily indicate "efficiency." Greider, The Soul of Capitalism: Opening Paths to a Moral Economy (New York: Simon \& Schuster, 2003), 241.

125 John Restakis, "The Lessons of Emilia Romagna" (2005), http://www.geo.coop/files/BolognaVisits Lessons_ER.pdf (accessed May 28, 2010). The bracketed figure comes from John Restakis, "The Emilian Model-Profile of a Cooperative Economy." 
(accounts vary) and 400,000 enterprises, making for a dense network of small and medium-sized firms. The major sectors are retail, manufacturing, and construction. ${ }^{126}$ Emilia-Romagna's success is due to the unique structure of its economy, sometimes called the Emilian Model: cooperative principles govern "the joint production and distribution of goods and services by private firms," most of which are not themselves cooperatives. Highly specialized small firms cooperate to produce a given product; most of the firms are subcontractors for the one that produces the finished good. ${ }^{127}$ At the same time, Mondragon's system of "secondary cooperatives," such as the Caja Laboral, that provide support to primary cooperatives has been replicated, so that small businesses share "service centers" for "research \& development, education \& training, marketing \& distribution, financing, technology transfer, workplace safety, environmental regulation, and a host of other services that help small and medium-sized firms to compete in a global marketplace. ... What all these centres have in common is that they replicate the advantages of large corporate structures for the collection and application of global knowledge for production, while maintaining the strengths which are unique to small enterprise." ${ }^{\text {"28 }}$ Long-term support from the historically leftist regional government has been essential to the development of the Emilian Model.

In short, there are many ways in which cooperatives can be made to work. Even isolated co-ops can be successful if they have access to capital. As we have seen, cooperatives typically fare as well as or better than capitalist enterprises in relation to longevity, productivity,

${ }^{126}$ Eurostat, "Emilia-Romagna: Economy,” http://circa.europa.eu (accessed May 28, 2010).

${ }^{127}$ Alberto Rinaldi, "The Emilian Model Revisited: Twenty Years After," Materiali di discussione del Dipartimento di Economia politica, no. 417 (September, 2002): 3. Another author writes, "In Italy cooperatives in similar industrial sectors and regions have established consortia to enable them to engage in joint purchasing and bid for contracts jointly." Cornforth, 223.

${ }^{128}$ Restakis, "The Emilian Model—Profile of a Cooperative Economy,” 3. 
wages (sometimes), working conditions, democratic organizational structures, the potential for ensuring long-term employment, and even profitability (if they have enough capital). Their rarity is due to their low rate of formation, which is due in large part to difficulties in securing capital, but also to a lack of will or knowledge among the populace. People have to be educated on the possibilities open to them, shown where to look for resources, how to start a business together. Starting a business is hard work; it requires initiative, resourcefulness, and intelligence. But it is done all the time, though usually by capitalist-minded entrepreneurs; there is no reason to think that a small group of cooperators cannot do the same thing, especially if assisted by any of the dozens of organizations in the U.S. that exist for this purpose. Policy changes would help too-and have been forthcoming recently, as when the Small Business Administration started providing loans to worker cooperatives. ${ }^{129}$ There is still a long way to go, though, especially considering that the hostility of the American government (on federal and state levels) as compared to the governments of Italy and France has historically been a major impediment to the formation of worker cooperatives in the U.S. Even today, the federally chartered National Cooperative Bank tends not to lend to worker co-ops. A priority of activists should be (and is) to change such policies. In fact, governments committed to the reduction of current high rates of unemployment would be well-advised to facilitate proactively the formation of cooperatives of all kinds.

In some cases, they are already doing so. Influenced by a coalition of community groups, the New York City Council passed a historic budget in the summer of 2014 that created a $\$ 1.2$ million fund for the growth of worker-owned cooperatives. Richmond,

${ }^{129}$ Micha Josephy, "SBA Recognizes Worker Cooperatives as Small Businesses," Grassroots Economic Organizing (GEO) Newsletter, Vol. 2, Issue 12 (2012). See also Andrea Buffa, "Evergreen Cooperatives Forge an Innovative Path toward High-Quality Green Jobs," CommonDreams.org, April 17, 2010, http://www.commondreams.org/headline/2010/04/17-3 (accessed May 28, 2010). 
California has hired a cooperative developer and is launching a loan fund; Cleveland, Ohio has been actively involved in starting a network of cooperatives, as we'll see in the next chapter; and Jackson, Mississippi elected a mayor (Chokwe Lumumba) in 2013 on a platform that included the use of public spending to promote coops. On the federal level, progressive politicians like Bernie Sanders are working to get the government more involved in supporting employee ownership. ${ }^{130}$

So there is cause for optimism. Hopefully this chapter has convinced skeptical readers that co-ops have great potential, and that if they are rare now it is not because of inherent flaws in the model. With education, technical support, policy changes, and capital-all of which, it is worth remembering, have been crucial to the global success of capitalist businesses - cooperativism could be the next great movement of American history, indeed of world history.

\footnotetext{
${ }^{130}$ Rebecca Burns, "Worker-Owners Cheer Creation of \$1.2 Million Co-op Development Fund in NYC," In These Times, July 2, 2014.
} 



\section{CHAPTER THREE WORKER COOPERATIVES IN AMERICAN HISTORY}

Despite its reputation for individualism and unbridled capitalism, the United States has a history rich in cooperation and communalism. From the colonial era to the present-and among the indigenous population for millennia-local communities have engaged in selfhelp, democracy, and cooperation. Indeed, the "individualistic" tradition might more accurately be called the "self-help" tradition, where "self" is defined not only in terms of the individual but in terms of the community (be it family, township, religious community, etc.). Americans are traditionally hostile to overarching authorities separate from the community with which they identify, a hostility expressed in the age-old resentment towards both government and big business. The stereotype, based on fact, is that Americans would rather solve problems on their own than rely on political and economic power-structures to do so. The following brief survey of the history substantiates this claim. While my focus is on worker cooperatives, I will not ignore the many and varied experiments in other forms of cooperation and communalism.

Certain themes and lessons can be gleaned from the history. The most obvious is that a profound tension has existed, constantly erupting into conflict, between the democratic, anti-authoritarian impulses of ordinary Americans and the tendency of economic and political power-structures to grow extensively and intensively, to concentrate themselves in ever-larger and more centralized units that reach as far down into society as possible. Power inherently tries to control as much as it can: it has an intrinsic tendency toward totalitarianism, ideally letting nothing, even the most trivial social interactions, escape its oversight. Bentham's Panopticon is the perfect emblem of the logic of power. Other social forces, notably people's strivings for freedom and democracy, typically keep this totalitarian tendency in check.

In fact, the history of cooperation and communalism is a casestudy in the profound truth that people are instinctively averse to the 
modes of cutthroat competition, crass greed, authoritarianism, hierarchy, and dehumanization that characterize modern capitalism. Far from capitalism's being a straightforward expression of human nature, as apologists proclaim, it is more like the very antithesis of human nature, which is evidently drawn to such things as free selfexpression, spontaneous "play," 131 cooperation and friendly competition, compassion, love. The work of Marxist historians like E. P. Thompson shows how people have had to be disciplined, their desires repressed, in order for the capitalist system to seem even remotely natural: centuries of indoctrination, state violence, incarceration of "undesirables," the bureaucratization of everyday life, have been necessary to partially accustom people to the mechanical rhythms of industrial capitalism and the commodification of the human personality. ${ }^{132}$ And of course resistance continues constantly, from the early nineteenth century to the present day. "Wage-slavery," as workers in the nineteenth century called it, is a monstrous assault on human dignity, which is why even today, after so much indoctrination, people still hate being subordinated to a "boss" and rebel against it whenever they can. The history of worker cooperatives in particular shows that commitment to the ideals of workplace democracy, indeed worker ownership and control, is just below the surface of mass consciousness. A spark could light a fire.

From this history one can draw another lesson, more limited in scope: most cooperatives have been formed during economic contractions or waves of political and social movements. On the other hand, many cooperatives, like all kinds of businesses, have

\footnotetext{
${ }^{131}$ See Johan Huizinga, Homo Ludens (Boston: Beacon Press, 1955).

${ }^{132}$ See E. P. Thompson, The Making of the English Working Class (New York: Vintage Books, 1966), as well as the enormous literature Thompson helped spawn on Victorian cultural repression, welfare capitalism, Fordism, the regulatory obsessions of Progressivism, and in general the history of labor movements everywhere in the world. The work of scholars who analyze corporate propaganda is pertinent as well; Alex Carey, Taking the Risk Out of Democracy: Corporate Propaganda versus Freedom and Liberty (Urbana: University of Illinois, 1996) exemplifies this scholarship.
} 
succumbed to economic contractions. The best way to prevent that is by building up a thick mesh of institutional networks, cooperative federations, and ideologically friendly banks. Fortunately, this is happening now. As it continues, moreover, society will no longer have to wait for recessions to stimulate the creation of new co-ops; they will be born continually around the world, as organizers spread the gospel and help provide the capital. Effectively there will be a continuous social movement.

This also suggests that another pitfall of earlier movements has finally been overcome: each generation of past cooperators often had to begin anew, relearning the lessons of their forebears, because most cooperative institutions did not extend sufficiently in time or in space. Even if knowledge and capital could be accumulated over many years - which they usually could not-the means of coordinating a continent-wide movement did not exist. Now they do, increasingly so every year.

More generally, a lesson of the history of radical social movements is that advances in freedom or against power-structures do not occur as quickly as activists would like or expect them to. Radicals in the 1880s, 1910s, 1930s, 1960s, and so on, thought that society was on the cusp of a social revolution. Strictly speaking, though, society is never on the "cusp" of a social revolution, because these things take an inordinate amount of time. I'll return to this subject in the next chapter; suffice it to say that the history of cooperativism is an excellent illustration of the slowness of systemic change, the necessity for revolutionists to be dedicated to decades of slow, patient organizing as opposed to sweeping assaults on the fortress of capitalism. To use Antonio Gramsci's terms, the "war of position" is more important than the "war of maneuver" 133 precisely because, with regard to a social revolution, the war of maneuver should be seen not as separate from and subsequent to the war of position, as Gramsci saw it, but as a component in the latter.

${ }^{133}$ See David Forgacs, ed., An Antonio Gramsci Reader: Selected Writings, 1916-1935 (New York: Schocken Books, 1988). 
Radicals should always be testing the strength of reactionary powerstructures, pushing against them directly through political "maneuvering" to enact reforms that erode their power and conservatism, while at the same time educating and organizing the multitudes partly as a basis for these political actions. This is the process through which most genuine, long-term progressive achievements have been won, as opposed to abortive "revolutions" like Lenin's in 1917 (which led to Stalinism). In the long run, Leninist impatience does not work.

Anti-capitalist movements in the U.S. were fitful and sporadic prior to the Civil War, although horror at the excesses of early industrialism was widespread even among the privileged, and the miseries of the lower classes in urban and rural areas fostered a seething discontent that exploded in events like the Flour Riot of 1837, Dorr's Rebellion in the 1840s, the Anti-Renter movement in the Hudson Valley around the same time, innumerable strikes by factory workers, and the formation of the world's first Workingmen's Parties in New York and other states. ${ }^{134}$ The frequently wretched work conditions of the first half of the nineteenth century are well known. ${ }^{135}$ Less well known are the early, tentative experiments in alternative social and economic arrangements. In the very early nineteenth century workers occasionally formed cooperatives while on strike, or after a strike had failed. In Baltimore, a cooperative shoemakers' manufactory was organized in 1794; in 1806, Philadelphia shoemakers organized another cooperative manufactory. Such actions became increasingly common in the early labor movement, especially among artisans and

\footnotetext{
${ }^{134}$ See, e.g., Howard Zinn, A People's History of the United States (New York: Harper Collins, 2003), chapter ten, and Joseph Rayback, A History of American Labor (New York: The Free Press, 1966), chapter six.

${ }^{135}$ See Peter Way, Common Labor: Workers and the Digging of North American Canals, 1780-1860 (Baltimore: Johns Hopkins University Press, 1997) and Seth Rockman, Scraping By: Wage Labor, Slavery, and Survival in Early Baltimore (Baltimore: Johns Hopkins University Press, 2008).
} 
craftsmen. ${ }^{136}$ A less oppositional sort of cooperativism was practiced by immigrants from Europe, as it would be in later waves of immigration as well: they formed communities in cities on the east coast in which mutual-aid structures were essential to survival.

At the same time, communalism of both secular and religious varieties was trying to gain a foothold in the U.S. Communalism has been a recurring phenomenon in American history, from the early seventeenth century to the 1970s and beyond: a group of like-minded people get together and establish a community on the fringes of American society, away from the capitalist rat-race. Quakers, Shakers, Mormons, Rappites, Christian Socialists, and other religious groups founded cooperative communities in the late eighteenth century and early to mid-nineteenth century, usually with at most a few hundred members. Some of them were quite successful, lasting decades; others ended after a few years because of personality clashes or organizational problems. ${ }^{137}$

Secular communalism was not wildly successful either. The British businessman Robert Owen came to the U.S. in 1825 to spread his new socialist ideas and start experimental communities at New Harmony, Indiana and other locations. With 900 people, New Harmony did impressively well for a while - so well, in fact, that Owen prematurely changed its status and structure into that of a commune, with means of survival held in common and remuneration based on need rather than work. This enterprise failed miserably: the township was too diverse, consisting, as Owen's son said later, of "a heterogeneous collection of radicals, enthusiastic devotees to principle, honest latitudinarians, and lazy theorists, with a sprinkling of unprincipled sharpers thrown in," and infighting spelled its doom. The whole Owenite movement effectively collapsed in $1828 .{ }^{138}$

${ }^{136}$ Curl, For All The People, 34.

${ }^{137}$ Ibid., chapter 18.

138 Edwin Charles Rozwenc, Cooperatives Come to America: The Protective Store Movement, 1845-1867 (Philadelphia: Porcupine Press, 1975), 7; Joseph Clayton, Robert Owen: Pioneer of Social Reforms (London: A. C. Fifield, 1908), 43. See also Mark Holloway, Heavens on 
A second wave of communalism began in the $1840 \mathrm{~s}$, when Charles Fourier's ideas were put to the test. Horace Greeley, a disciple of Fourier, summarized these ideas eloquently:

Not through hatred, collision, and depressing competition; not through war, whether of nation against nation, class against class, or capital against labor; but through union, harmony, and the reconciling of all interests, the giving scope to all noble sentiments and aspirations, is the renovation of the world, the elevation of the degraded and suffering masses of mankind, to be sought and effected. ${ }^{139}$

Associationists, as they were called, hoped that "phalanxes," Fourier's ideal communities, would eventually sprout all over the country and transform it from a competitive to a harmonious, cooperative society. Owen's followers had focused on cooperative agriculture, but Fourier's emphasized industry, since times had changed since the 1820s. Dozens of phalanxes with at least a hundred members each were founded in the eastern half of the country. But after a few years the old problems with Owen's movement returned: most poor people couldn't afford to found phalanxes, even after combining their resources, and the phalanxes they did form usually remained poor, "strangled by debts they had undertaken." ${ }^{140}$ Participants expected the new communities to magically solve their economic problems; when they didn't, and in fact added such new stress to life that many people "burned out," the movement lost its vitality and collapsed (after ten years or so).

Concomitant with Associationism was a renewed union worker cooperative movement. After the case Commonwealth v. Hunt,

Earth: Utopian Communities in America, 1680-1880 (New York: Dover, 1966).

${ }^{139}$ Quoted in John Commons et al., History of Labour in the United States, Vol. 1 (New York: The Macmillan Company, 1918), 497.

${ }^{140}$ Curl, For All The People, 292. 
decided by the Massachusetts Supreme Court in 1842, established that labor unions had the right to exist, unions grew quickly throughout the east. Strikes erupted in the late 1840s in response to wage cuts brought on by a depression, and cooperatives were formed in the wake of these strikes. For instance, the iron molders of Cincinnati struck in 1847, lost, and then organized a successful cooperative foundry: the 47 members collected $\$ 2100$ with which to buy land, and philanthropists from Cincinnati erected buildings for the new business. ${ }^{141}$ Unions established cooperatives in many states - often as a response to failed strikes - and among such diverse groups as glassblowers, cabinetmakers, barrel-makers, seamstresses, tailors, and hat-finishers. ${ }^{142}$ Europeans who had emigrated after the failed revolutions of 1848 also started many cooperatives in eastern cities. On the whole, however, this wave of cooperativism was over by the mid-1850s, having succumbed to a lack of resources and fierce capitalist competition. The depression of the mid-1850s also wreaked havoc on cooperatives, and the Civil War eliminated most of the few that still remained.

But before that final catastrophe happened, consumer cooperatives made their first major appearance in the U.S., between 1845 and 1860. In a consumer cooperative, as opposed to a worker cooperative, "the customers are the voting members who band together to acquire consumer goods directly from producers and eliminate the profits of middlemen [i.e., retailers]. The workers in the cooperative may or may not be members." ${ }^{143}$ Consumer co-ops are more capitalistic than worker co-ops in that, while the property is collectively owned by consumer-members, managers exist (appointed by a board of directors elected by the membership) who hire and fire workers as in a capitalist enterprise. Nevertheless, the co-op has definite advantages over the private enterprise, not the least of which is that it can sell goods more cheaply, at close to cost, by eliminating the middleman. This is what the Working Men's

${ }^{141}$ Commons, History of Labour in the United States, Vol. 1, 565.

${ }^{142}$ Curl, For All The People, 50.

${ }^{143}$ Ibid., 53. 
Protective Unions did, approximately 800 of which were established in New England and Canada between 1845 and 1860, servicing 30,000 to 40,000 members and tens of thousands of non-members. ${ }^{144}$ The movement was stimulated by the harsh economic climate for working people of the $1840 \mathrm{~s}$, and also by the energy of radical European immigrants who carried the frustrated hopes of the 1848 revolutions to America. The hundreds of stores provided cooperative employment and inexpensive goods, and devoted much of their financial surplus to insurance for the aged and the sick. And yet the movement lasted only a few years because of the aforementioned problems of debt, lack of resources, and economic depressions in the 1850s. It also fatally incurred the wrath of capitalists for selling goods too cheaply: private enterprises used the tactics of priceslashing and blacklisting to drive the co-ops out of business, after which prices were raised again. ${ }^{145}$

The Rochdale consumer-cooperative movement in England, which began around the same time as the Protective Unions in the United States, avoided some of the latter's mistakes, particularly the mistake of selling goods much more cheaply than conventional businesses did. Instead, the Rochdale cooperators pioneered a device that has been used to great effect ever since: rather than every customer's paying a low price, "regular" prices were charged but rebates periodically given to members (greater rebates going to those who purchased goods more frequently). ${ }^{146}$ This mollified capitalist competitors. At the same time, the Rochdale group was better able to secure financing for its operations by relying not merely on small membership fees, as in the Protective Unions, but also on shares of equity sold to members, who thereby could earn a fixed dividend of

\footnotetext{
${ }^{144}$ Rozwenc, Cooperatives Come to America, 116, 120.

${ }^{145}$ Curl, For All The People, 55.

${ }^{146}$ Edward Bemis, "Cooperation in New England," in Herbert B. Adams, ed., History of Cooperation in the United States (Baltimore: Johns Hopkins University, 1888), 46.
} 
no more than five percent. ${ }^{147}$ Another important contribution of Rochdale was to formulate concrete principles of cooperation that have been embraced by cooperators for 150 years. Among them are the following: voluntary and open membership; democratic member control; member economic participation, such that capital is equitably contributed to the business; autonomy and independence; education and training (of members and the general public, to spread the ideology of cooperation); cooperation among cooperatives; and concern for community. Hundreds more cooperative stores opened in America after the Civil War, most of them modeled on the Rochdale system rather than the failed Protective Unions.

It is after the Civil War, during the "second industrial revolution," that the history of cooperativism becomes really exciting, full of promise and tragedy. Organizations like the National Labor Union, the Sovereigns of Industry, the Knights of St. Crispin, and the Knights of Labor enthusiastically supported cooperation and proselytized for it. Around the time of labor's Great Upheaval (the late $1870 \mathrm{~s}$ and 1880s), thousands of cooperative stores and workshops were born around the country, especially in the east. Hundreds of thousands of laborers and artisans had faith in cooperation - at least in the long run - as an escape from industrial misery, low wages, and periodic unemployment, hoping to mold society anew in the image of a "republic of labor," which would be a continuation and fulfillment of the Founding Fathers' republican political vision. Labor reformers thought that in order for liberty, equal rights, and the pursuit of happiness to flourish, social conditions would have to be revolutionized: cooperation would have to supersede "wage-slavery," so that economic reality could be made consistent with America's democratic form of government. "The principles of Co-operation," wrote a reformer in the late $1860 \mathrm{~s}$, "are more in harmony with the principles of our form of government than

${ }^{147}$ Steven Leikin, The Practical Utopians: American Workers and the Cooperative Movement in the Gilded Age (Detroit: Wayne State University Press, 2005), 4. 
our present social system." ${ }^{\text {"148 }}$ The dream of this cooperative utopia inspired reformers for decades.

For example, in the late 1860s the newly formed National Labor Union, a loose federation that had over 300,000 members before it collapsed in 1873, endorsed cooperation and sponsored the creation of many cooperatives. William Sylvis, its president, declared that "Of all the questions now before us, not one is of so great importance, or should command so large a portion of our consideration, as co-operation... Co-operation is the only true remedy for low wages, strikes, lock-outs, and a thousand other impositions and annoyances to which workingmen are subjected." 149 The NLU even petitioned Congress to spend \$25 million on establishing cooperatives. Many local unions in New England organized co-ops to support strikes or in the case of a lockout, but continued to operate them after the strike or lockout had ended. For instance, between 1866 and 1876, iron molders established at least 36 foundries and shoemakers at least 40 workshops, most of which were responses to failed strikes or lockouts. In fact, nearly all the important trades assayed cooperation in the years after the Civil War, including bakers, coach-makers, coal miners, shipwrights, machinists, blacksmiths, plumbers, tailors, printers, and many others. $^{150}$

The Knights of St. Crispin, a shoemakers' union (excluding unskilled labor) that was founded in 1867, were equally zealous in their propagandizing for cooperative work. They were among the most powerful unions in the world: with over 50,000 members, by December, 1870 they had scores of lodges in Massachusetts, New

${ }^{148}$ John Samuel, quoted in Leikin, The Practical Utopians, 32. On the Knights of Labor, see, e.g., Gerald N. Grob, Workers and Utopia: A Study of Ideological Conflict in the American Labor Movement, 1865-1900 (Chicago: Northwestern University Press, 1961) and Leon Fink, Workingmen's Democracy: The Knights of Labor and American Politics (Chicago: University of Illinois Press, 1983).

${ }_{149}$ Curl, For All The People, 66.

${ }^{150}$ Commons et al., History of Labour in the United States, Vol. 2, 111. 
York, New Hampshire, Ohio, Michigan, Pennsylvania, Indiana, Wisconsin, New Jersey, and California. Like other national unions of the period they were decentralized, and so they mostly left it to the initiative of local branches to found co-ops. But it was recommended that every lodge consider starting a cooperative workshop and a store. In Massachusetts, by 1869 the Crispins had organized between 30 and 40 cooperative stores; in the following years they organized workshops in New England, New York, New Jersey, and other states. ${ }^{151}$ The Crispins disappeared in the late 1870 s, but the Knights of Labor would go on to form cooperative shoe shops in the $1880 \mathrm{~s}^{152}$

The methods of financing and organizing all these workshops and stores varied. Since the labor movement was highly decentralized at the time, the initiative usually lay with the local branches of unions. These comprised mostly skilled workers and craftsmen hostile to unskilled labor and the development of industry because it threatened to deprive them of their livelihood and the pride they took in their work. (Mass unionization of "unskilled" workers did not come into its own until the late 1930s, with the founding of the CIO. Craft unions, organized by occupation rather than industry, were the norm at the end of the nineteenth century.)

So how did these craftworkers start all their co-ops? The main obstacle was and is the need for capital. One common tactic was to require workers to purchase shares of stock, which would earn a small dividend. Perhaps after a failed strike at a capitalist business, a dozen carpenters in a union would get together and decide to form a co-op. Often they wrote letters for advice to labor leaders like William Sylvis, John Samuel, and Thomas Phillips, inquiring, for example, as to whether it was better to distribute profits on the basis of shares owned or of labor performed. They might start a retail store as a way to accumulate capital for production. In the $1880 \mathrm{~s}$, local and district assemblies of the Knights of Labor oversaw the creation of cooperative businesses, and it became common practice to open a

${ }^{151}$ Don D. Lescohier, The Knights of St. Crispin (New York: Arno, 1969), $50,51,52$.

${ }^{152}$ Curl, For All The People, 75. 
store first. Victor Drury, a French immigrant influential in the labor movement, recommended that products be sold in the store at slightly above cost, only until

we could sell at cost those commodities which we should produce ourselves as soon as we begin to manufacture. So soon as we could find sale for sufficient of the products of any of the industries we have mentioned to employ a few producers, we should establish a workshop or centre of production. For instance, if we sold sufficient bread and pastry to employ four or five bakers, we should immediately establish a bakery... We should then call upon the Trades' Unions to furnish us with the most skilled and capable men in their special industries to direct these centres of production. ${ }^{153}$

Drury was a member of the Knights of Labor's District Assembly 49 in New York, which organized many cooperatives that were managed by a designated committee. It sold shares in an organization called the Solidarity Co-operative Association, which invested over $\$ 6000$ in various enterprises. No interest was paid to the shareholders, nor did they have any control over the management of the firms; instead, the association would buy back the shares later and reinvest 50 percent of its profits in cooperation. By 1887, the Solidarity Association was running eight businesses, one of which had capital of $\$ 67,000$ and employed over 100 workers. ${ }^{154}$

Most of the cooperative businesses of the 1860s and 1870s-like many private enterprises-succumbed to one of the several depressions that rocked the nation in those decades, such as the severe slump of 1873. But the Knights of Labor picked up where the National Labor Union and the Sovereigns of Industry (among other

153 Victor Drury, The Polity of the Labor Movement (Philadelphia: Frederick Turner, 1885), 61, 62.

${ }^{154}$ Leikin, The Practical Utopians, 83. 
groups) had left off, and it was in the 1880s that cooperativism had its greatest successes.

The Knights of Labor originated in the late 1860s and early 1870 s in Philadelphia, but slowly expanded into the rest of Pennsylvania and finally became a national organization with 750,000 members. It encompassed many trade unions and was organized geographically rather than by occupation. "The Knights attempted to organize all American productive workers into 'one big union' regardless of skill, trade, industry, race or sex and were divided into local, district and national assemblies, with a centralized structure" 155 - although substantial autonomy was granted to local assemblies, which took the initiative in establishing hundreds of cooperative stores and factories. The national leadership was less energetic on this score than local leadership. The overarching purpose of the organization was, as its longtime leader Terence Powderly said, "to associate our own labors; to establish cooperative institutions such as will tend to supersede the wage-system, by the introduction of a co-operative industrial system." 156 To this end, the Knights lobbied politically, engaged in numerous strikes, lent their support to other radical social movements, and, of course, organized co-ops. Masses of workers genuinely believed that they could rise from being "rented slaves" to become cooperators in control of their work and wages, living in revitalized and stabilized communities, no longer subject to periods of unemployment. Cooperation was a religion for some of them.

In 1880 the delegates to the General Assembly of the Knights of Labor earmarked 60 percent of regular dues for cooperatives; in the following years they also levied a compulsory monthly tax on members and subsequently a voluntary one. But in 1884 the Cooperative Fund was still only $\$ 974.52 .{ }^{157}$ On the other hand, the national leadership was willing to spend $\$ 20,000$ over several years

\footnotetext{
${ }^{155}$ Curl, For All The People, 88.

${ }^{156}$ Terence Powderly, Thirty Years of Labor: 1859 to 1889 (Columbus, Ohio: Excelsior, 1889), 453.

${ }^{157}$ Leikin, The Practical Utopians, 57.
} 
to support a coal mine that had been started by eight miners in 1883 after they leased a forty-acre plot. They ran into financial troubles and appealed to the Knights' Executive Board, with the result that this Indiana mine became the first major production cooperative to be run directly by the central organization. As John Curl states, "the Knights intended the mine to be the first link in the economic backbone of the new society they planned to build." ${ }^{58}$ However, after buying the land, equipping the mine, and laying railroad tracks to it, the Knights discovered that the railroad company would not connect their switch to the main track for nine months. Later they found out that they would have to provide their own switch engine, which they could not afford. Such problems accumulated, and in the end the Knights leased the mine and finally sold it.

As already noted, more successful than these centralized efforts were the hundreds of projects initiated by local assemblies or unions. Minneapolis in the $1880 \mathrm{~s}$ was a particularly exciting place for cooperators, who were running 35 or 40 businesses. ${ }^{159}$ There were eight cooperative barrel factories, eight building-and-loan associations, two print shops, and one grocery store, shirt factory, house construction company, library, cigar factory, dry-goods store, laundry, and a 250-acre cooperative colony miles from the city. Most of these businesses were started between 1882 and 1886, when the Knights had a strong presence in the city, though some of the barrelmaking factories dated from the ' $70 \mathrm{~s}$. These came to dominate the city's barrel industry; in 1887 they grossed over a million dollars' worth of business and employed 368 journeymen-owners out of 593 coopers in the city. Evidently their methods of capitalization served them well: each of the sixteen original members of the first factory (in 1874) bought a $\$ 15$-share initially and paid $\$ 5$ to the business every week thereafter, which eventually allowed them to buy a shop near the railroad. New members had to buy shares, which they could purchase from departing members (if there were any). Through these

${ }_{158}$ Curl, For All The People, 91.

${ }^{159}$ The information in this paragraph comes from ibid., 96-100, and Leikin, The Practical Utopians, chapter five. 
simple means, and the high demand for barrels among millers, the business was able to expand and spawn others, until a veritable cooperative community developed that maintained admirable cohesiveness despite the mixture of ethnicities-German, Swedish, Norwegian, Irish, Italian, and American.

It's worth quoting Albert Shaw, a nineteenth-century historian, on the salutary effects of cooperation among the Minneapolis coopers:

Coöperation has developed business capacity in the men which they were not aware of possessing because they had never tested it. The conduct of the shops from the governmental point of view may well encourage one's belief in democracy. Sound judgment almost invariably prevails... Dissension is almost unknown. Differences of opinion are not infrequent, but the will of the majority is acquiesced in without strain... The coopers themselves are emphatic in saying that the moral effects of their coöperative movement constitute its highest success. It has unquestionably wrought a transformation in the character of these craftsmen. They are no longer a drunken, disreputable guild, figuring in the police courts and deserving the disfavor of the community. They have become a responsible and respectable class of citizens... ${ }^{160}$

The key to their economic success, of course, was institutional support. This is always essential to the success of any oppositional movement. A rich network of mutually supporting institutions is necessary, helping each other with finances, publicity, organizational and recruiting work, "moral support," etc. It is necessary to build a genuine community outside the mainstream. The Minneapolis coopers had this community, as testified by Shaw:

\footnotetext{
${ }^{160}$ Albert Shaw, "Coöperation in the Northwest," in History of Cooperation in the United States, 236, 238.
} 
In Minneapolis there are men who are earning their living in a cooperative cooper shop, paying for their home through a cooperative building and loan association, buying their groceries at a cooperative store, and having their washing done in a cooperative laundry. Some of them perchance enjoy the advantages of membership in a cooperative neighborhood improvement association, obtain books and magazines from a cooperative reading club or library association, and so on. Many of them belong to societies and orders which have as their most practical feature a system of cooperative life and accident insurance. $^{16}$

However, the experience of the cooperative coopers is illuminating also with regard to the challenges they faced. For example, they had an ambivalent relationship with the labor movement and the Knights of Labor. On the one hand, the Knights provided institutional support and leadership. Indeed, the main reason cooperation failed in Minneapolis after 1887 was the organizational decline of the Knights. ${ }^{162}$ On the other hand, the cooperators were running a business and so did not always have the same interests as the journeymen coopers, the wage-laborers, who were employed in conventional workshops with bosses. At times they acted in solidarity with their fellow workers, while at other times their business interests put them at odds with the labor movement. Some of the cooperators even hired journeymen and machine operators in their shops and so became employers themselves. The Knights actually expelled the members of one co-op from the local Assembly for acting too independently vis-à-vis ordinary workers. Such conflicts are, as we saw in the last chapter, always a possibility given the ambiguous nature of the worker cooperative. ${ }^{163}$

\footnotetext{
${ }^{161}$ Quoted in Leikin, The Practical Utopians, 129.

${ }^{162}$ Ibid., 152.

${ }^{163}$ Ibid., 140-151.
} 
As the Knights expanded over the continent-especially after 1885, when they won a major nationwide strike against Jay Gould's railroad company - worker cooperatives followed in their wake, at least 334 of them between 1880 and 1888 (according to one study), ${ }^{164}$ in 35 of the 38 states. Many were a response to the depression of 1883-85, when wages were cut an average 15 percent, causing workers to look to other sources for income. ${ }^{165}$ The businesses they started were not "factories" as we understand the term, with its connotations of mass production and assembly-line workers, but rather workshops in which skilled craftsmen or semiskilled workers supervised themselves and each other, sometimes with an almost obsessive concern for democratic procedures. The minutes of general meetings attest to this preoccupation with democracy, given the insistence on having formal votes on almost every conceivable matter. ${ }^{166}$ Workers were always very reluctant to fire a fellow worker, and it seems to have happened in only the most exceptional cases.

Indeed, aside from their predictable sexism and racism, the attitudes and behavior of cooperators in the Gilded Age seem not to have differed substantially from those of cooperators eighty or a hundred years later, at least with respect to relationships in the workplace itself. There was the same emphasis on freedom and democracy, on realizing the inherent dignity of work, and the same struggle to reconcile cooperative ideals with the pressures of the market and hostility of conventional businesses. There was also a progressive desire to organize women, or for women to organize themselves: in Chicago, for example, women in the Knights of Labor organized twenty cooperatives in the clothing industry. Forty women established one such co-op after being locked out by their employer; they bought shares of stock for ten dollars each, distributed the

${ }^{164}$ See Curl, For All The People, 92.

${ }^{165}$ Rayback, A History of American Labor, 160.

${ }^{166}$ See Leikin, The Practical Utopians, 99. 
profits equally among the workforce, and worked only eight hours a day. $^{167}$

There were, however, major differences between the respective upsurges of cooperativism in the $1880 \mathrm{~s}$ and the $1960 \mathrm{~s}$, centered around the fact that the earlier one was part of a broad-based labor movement, unlike the later. Thus, the skilled and semi-skilled cooperators during the 1870 s and 1880 s explicitly used cooperatives as a way to guarantee employment, and arguably they were more ambitious, with their revolutionary hopes for a cooperative commonwealth. Their ideology, of course, was not the educated middle-class countercultural and anti-authoritarian one of the 1960s' youth movements but "laborist," "producerist," devoted to the Jeffersonian ideal of a republic of free laborers, mostly artisans and craftsmen. Some scholars have argued that this fact proves the Knights of Labor were "backward-looking" rather than truly revolutionary - that the future lay in mass production, not skilled labor or artisanry ${ }^{168}$ - but this criticism seems partly off the mark. It is true that the Knights were hostile to mechanization, just as workers have been in the era of the AFL-CIO, because in both cases it threatened to put them out of a job or to result in the lowering of wages and the deskilling of work. If this aversion to the degradation and mechanization of work is reactionary, so be it. But it is also a source of such revolutionary demands as democratization of production relations, cooperative organization of the economy, public ownership of industry, destruction of the capitalist class and its frequent tool the state, and other hopes cherished by millions of workers in the late nineteenth century.

${ }^{167}$ James Green, Death in the Haymarket (New York: Pantheon Books, 2006), 152.

${ }^{168}$ Needless to say, it is a caricature of the Knights' position to say they wanted an economy entirely of small artisanal workshops and small producers. Rather, they desired public control of transportation and communication systems and cooperative administration of mines and other massive industrial facilities. 
In reality, the Knights of Labor were radical and conservative at the same time. They were genuinely progressive in their political positions, such as abolition of child labor, support for the eight-hour day, advocacy of public ownership of the railroads, water systems and utilities, support for the women's movement and "equal pay for equal work," attempt to organize all workers into "one big union," and so forth. They were conservative insofar as they still exalted the ethos of artisanry and rejected, in their prescriptions for a future economic system, nationwide socialist institution-building, something like the plan put forward by Henry Sharpe when he was president of the Knights of Labor's Cooperative Board in the mid$1880 \mathrm{~s}$. He saw that large-scale and long-term cooperativism could not work as long as co-ops remained isolated units in a market economy. Dependence on wages could not be superseded that way; competition would always remain a fact of life, as would, therefore, the downward pressures on wages, the necessity to mechanize and expand, the subjection to the business cycle, etc. Instead, the Knights of Labor had to create their own self-sufficient world of cooperation-"a great industrial union, self-employing, selfsustaining, self-governing." The members, he said,

should be taught to look upon themselves as a "people," or, so to speak, as a nation, and the legislative, the executive, the judiciary, the industrial, the police, the insurance, the educational and the charities departments should all be well defined, properly officered and actively employed. It is high time that members be found whose special aptitudes incline them toward one or the other of the departments, and who, finding therein a field for their activities, develop their aptitudes still further and become specialists.

In effect, he was advocating state socialism. While his vision was impracticable and arguably morally objectionable, it had at least one virtue: as Steven Leikin says, it accepted "the organizational 
realities of the new industrial economy." 169 It anticipated the elaborate bureaucratic structures of the twentieth-century state, and hence was in no sense "conservative" or "reactionary." But the Knights refused to take cooperation to these limits. They would not consent even to compulsory taxes, much less to Sharpe's vision of centralized authority. Insofar, therefore, as they desired a cooperative society but would not make an all-out assault on capitalism or commit to building a network of alternative economic institutions, they can perhaps be called unrealistic and conservative. Similarly, inasmuch as bureaucracy, statism, and mass production represented "progress," the Knights, like anarchists and left-Marxists, were indeed ambivalent towards progress.

As it turned out, Sharpe was right. Cooperation succumbed to market forces, but even more to the war waged on it by the business classes. By 1887 the latter were determined to destroy the Knights, with their incessant boycotts, their strikes (sometimes involving hundreds of thousands), their revolutionary agitation, and their labor parties organized across the country. In the two years after the infamous Haymarket bombing in Chicago and the Great Upheaval of 1886 , in which 200,000 trade unionists across the country went on a four-day-long strike for the eight-hour day but in most cases failedpartly because Terence Powderly, the leader of the Knights, who had always disliked strikes, refused to endorse the action and encouraged the Knights not to participate-capitalist repression swept the nation. Joseph Rayback summarizes:

The first of the Knights' ventures to feel the full effect of the post-Haymarket reaction were their cooperative enterprises. In part the very nature of such enterprises worked against them. The successful ventures became jointstock corporations, the wage-earning shareholders and managers hiring labor like any other industrial unit. In part the cooperatives were destroyed by inefficient managers,

${ }^{169}$ Leikin, The Practical Utopians, 65. See pages 60-66. 
squabbles among shareholders, lack of capital, and injudicious borrowing of money at high rates of interest. Just as important was the attitude of competitors. Railroads delayed the building of tracks, refused to furnish cars, or refused to haul them. Manufacturers of machinery and producers of raw materials, pressed by private business, refused to sell their products to the cooperative workshops and paralyzed operations. By 1888 none of the Order's cooperatives were in existence. ${ }^{170}$

Thus, by 1888 it had become evident that a national cooperative movement could not succeed in America, at least not in the absence of sustained, massive and violent attack on the wage-system, far more massive and well-organized than the Knights' movement had been. As Henry Sharpe said, what they were doing was not realistic. Small workshops with little capital and obsolete machinery in an age of rapid industrialization; insufficient institution-building to give financial and material support to co-ops; enslavement to the market at a time when competitors would stop at nothing to suppress working-class moves toward independence. Especially with the weak leadership of Terence Powderly and the mass desertion of former Knights after 1886, as they lost strike after strike, the great dream of building a national cooperative economy was effectively over.

Farmers in the South, West, and Midwest, however, were still building a major movement to escape from the control of banks and merchants lending them supplies at usurious rates; agricultural cooperatives - cooperative buying of supplies and machinery and marketing of produce-as well as cooperative stores, were the remedy to these conditions of virtual serfdom. While the movement was not dedicated to the formation of worker co-ops, in its own way it was at least as ambitious as the Knights of Labor had been. In the late 1880 s and early 1890 s it swept through southern and western states like a brushfire, even, in some places, bringing black and white

${ }^{170}$ Rayback, A History of American Labor, 174. 
farmers together in a unity of interest. Eventually this Farmers' Alliance decided it had to enter politics in order to break the power of the banks; it formed a third party, the People's Party, in 1892. The great depression of 1893 only spurred the movement on, and it won governorships in Kansas and Colorado. But in 1896 its leaders made a terrible strategic blunder in allying themselves with William Jennings Bryan of the Democratic party in his campaign for president. Bryan lost the election, and Populism lost its independent identity. The party fell apart; the Farmers' Alliance collapsed; the movement died, and many of its cooperative associations disappeared. Thus, once again, the capitalists had managed to stomp out a threat to their rule. ${ }^{17}$

They were unable to get rid of all agricultural cooperatives, however, even with the help of the Sherman "Anti-Trust" Act of $1890 .{ }^{172}$ Nor, in fact, did big business desire to combat many of them, for instance the independent co-ops that coordinated buying and selling. Small farmers needed cooperatives in order to survive, whether their co-ops were independent or were affiliated with a movement like the Farmers' Alliance or the Grange. The independent co-ops, moreover, were not necessarily opposed to the capitalist system, fitting into it quite well by cooperatively buying and selling, marketing, and reducing production costs. By 1921 there were 7374 agricultural co-ops, most of them in regional federations. According to the census of 1919, over 600,000 farmers were

${ }^{171}$ See, e.g., Lawrence Goodwyn, The Populist Moment: A Short History of the Agrarian Revolt in America (New York: Oxford University Press, 1978); John D. Hicks, The Populist Revolt: A History of the Farmers' Alliance and the People's Party (Nebraska: University of Nebraska Press, 1961/31); and Charles Postel, The Populist Vision (New York: Oxford University Press, 2007).

${ }^{172}$ One of the innumerable ironies of history is that the Sherman Act was mostly used not against big business but against unions and cooperatives, even though its chief proponents had been workers, farmers, and small businessmen hoping to break the power of monopolies. Zinn, 260, and Curl, $118,119$. 
engaged in cooperative marketing or purchasing - and these figures did not include the many farmers who obtained insurance, irrigation, telephone, or other business services from cooperatives. ${ }^{173}$

From the 1890 s to the 1920 s, cooperation had its home mainly in the agricultural sector. The sheer number of regional and national organizations devoted to cooperation in agriculture testifies to this. There was the National Farmers Union, the American Society of Equity, the Non-Partisan League in North Dakota, the Farmer-Labor Exchange, the Farmers' Equity Union, the National Grange, Farm Bureaus all over the country-which in 1920 led to the American Farm Bureau Federation - to educate farmers on business methods and cooperation, many regional associations such as the California Fruit Growers Exchange (which became Sunkist), the California Associated Raisin Growers (now called Sunmaid), and the Missouri Farmers Association, and in the 1920s there emerged a variety of Communist farm organizations. Many of these associations had the financial and political support of the federal government, state governments, and business groups, who recognized that the atomistic, competitive model of classical capitalism was inappropriate to agriculture. ${ }^{174}$ The passage of the Capper-Volstead Act in 1922 was of great importance for marketing co-ops, since it determined that they did not violate the Sherman Act's prohibition of organizations in restraint of trade. Because of this exemption, marketing co-ops no longer had to worry about the sort of legal harassment they had endured for years. ${ }^{175}$

Consumer cooperativism, however-not to mention worker cooperativism - was not having much success around the turn of the century. In 1896 the American Federation of Labor decided to support consumer co-ops, but they did not become a priority of the labor movement. Many immigrant groups ran co-ops in the East and

${ }^{173}$ Joseph R. Knapp, The Rise of American Cooperative Enterprise: 16201920 (Danville, IL: Interstate Printers and Publishers, 1969), 432.

${ }^{174}$ Ibid., chapters ten and eleven.

${ }^{175}$ Joseph Knapp, The Advance of American Cooperative Enterprise: 1920 1945 (Danville: Interstate, 1973), 26. 
Midwest, and in the West there were several thriving associations, such as the Pacific Cooperative League, the Pacific Coast Cooperative Union, and the California Rochdale Company; but aside from these Western movements, and some Midwestern federations, there was little coordination or communication between co-ops. ${ }^{176}$ The Cooperative League of America was founded in 1916 with the mission of coordinating consumer cooperativism (although eventually it expanded its activities to apply to all co-ops). It joined the International Cooperative Alliance in 1917, and it exists today as the National Cooperative Business Association.

From the 1890 s to the 1930 s, worker cooperatives were almost entirely ignored by the labor movement. Neither the AFL nor the IWW had much interest in them; nor did the Socialist or the Communist Parties, nor even the Cooperative League. Labor activists seem to have learned their lesson from the fate of the 1880s' co-ops. Not until the Great Depression and its self-help movement would there be a resurgence of a type of producer cooperativism, and this time the movement would be even more spontaneous and decentralized than it had been under the Knights of Labor. Consumer co-ops, too, would make a comeback; they had not fared well during the 1920 s.

The self-help cooperative movement, which flourished between 1931 and 1935 but lasted in some form until 1938, originated not in production but barter. It involved the exchange of goods and services, with cooperators sometimes performing labor services on farms in exchange for meals. Productive associations, vaguely similar to worker co-ops, arose after 1934, oriented around such activities as butchering, plumbing, flour milling, logging and sawmilling, carpentry, dentistry, printing, coal mining, shoerepairing, etc. Over the course of the movement, more than half a million families were affiliated with 600 self-help organizations in

${ }^{176}$ Curl, For All The People, 140. 
37 states; about 250 of these were productive associations. ${ }^{177}$ The cooperatives thrived particularly around Los Angeles, San Francisco, Seattle, Salt Lake City, Denver, and Minneapolis. ${ }^{178}$

The production cooperatives differed in at least one crucial respect from ordinary worker co-ops: they relied heavily on government funding and government assistance-\$4,730,000 worth of funding. In 1933 a Division of Self-Help Cooperatives was set up in the Federal Emergency Relief Administration to administer the grants and set the rules that cooperatives receiving money would have to follow. One significant rule stated that no cooperatively produced goods could be sold on the open market. "In effect, a selfhelp economy was created which functioned separately from the open-market economy. These rules reflected the government's desire to allow the cooperative sector to operate as long as the free market was not disturbed." ${ }^{179}$ Evidently the government was comfortable with cooperatives insofar as they had a stabilizing influence on society and would provide a safe outlet for discontent.

The economic performance of the co-ops was not quite stellar, but it was not shabby either. Many or most of the workers were in their fifties or older-people who had particular difficulty finding employment-and so were less productive than the average employee in a comparable capitalist business. The cooperatives tended to be relatively small, and grew but slowly. They were, however, a very cost-effective way for the government to provide relief to the unemployed, because it seems that, had these co-ops not existed, the government would have spent far more on relief than it did. (Families who were eligible for relief did not apply for it,

${ }^{177}$ Derek Jones and Donald Schneider, "Self-Help Production Cooperatives: Government-Administered Cooperatives During the Depression," in Worker Cooperatives in America, 57.

${ }^{178}$ See Knapp, The Advance of American Cooperative Enterprise, 289-291. Clark Kerr's unpublished 1939 dissertation "Productive Self-Help Enterprises of the Unemployed" is the basic work on the self-help movement in the Great Depression.

${ }^{179}$ Jones and Schneider, "Self-Help Production Cooperatives," 59. 
instead relying on their cooperative income.) In addition, they provided a useful service as "rehabilitation" for the unemployed, who derived psychological benefits from working when otherwise they would have been idle and discouraged. Therefore, whatever one thinks of the government's motives in supporting the co-ops, and their systemically stabilizing effects, it can hardly be denied that they performed a valuable function for the families affected.

In the end, the main lesson of the self-help co-ops may be that government assistance can be of great use to cooperators and societal innovators, but they should be careful not to become too dependent on it. For then they are subject to the whims of bureaucrats, policymakers, and politicians, who may withdraw legislative and financial assistance if the political winds change. Government funding of self-help was not guaranteed and policies changed erratically, not always to the benefit of the co-ops. In any case, the movement lost much of its momentum after the Works Progress Administration was set up in 1935, providing employment for millions and thus obviating the need for the cooperatives.

The government also promoted cooperatives under the aegis of the Tennessee Valley Authority, in the mid- to late 1930s. As is well known, the TVA was conceived as a grand experiment in social reconstruction. It turned out to be quite successful, in no small part because of the fertilizer and electric cooperatives that the government helped set up. Indeed, the TVA served as the "incubator of the federally promoted and financed rural electrification program" that began in 1935, when only ten percent of the country's farms were electrified. Dozens of electrical power cooperatives had already been set up in the Midwest between 1914 and 1930, but it was only with the Rural Electrification Administration that the problem was tackled on a large scale. In December 1935, 789,000 farms were being served by public and private utility systems; five years later, largely as a result of the REA, the number was 1,871,942. By 1940 
more than half of rural America was still not electrified, but in the coming decades the job was completed. ${ }^{180}$

Agricultural cooperation thrived during the 1930s, again due to New Deal initiatives. In 1933 the Farm Credit Administration set up Banks for Cooperatives, a program that created a central bank and twelve district banks; it "became a member-controlled system of financing farmer cooperatives, as well as telephone and electric cooperatives." ${ }^{\prime 181}$ For the rest of the century, Banks for Cooperatives would prove an invaluable resource. Already by 1939 its financial assistance made it possible for half the farmers in the United States to belong to cooperatives.

With World War II and the end of the New Deal, and especially in conservative postwar America, cooperation in all spheres but agriculture plummeted. The political left went off to fight Hitler as the center gained control of the government and many unions. After the war the CIO was purged of Communists, dealing a huge blow to the labor movement. Through reactionary legislation like the TaftHartley Act, military and police violence against unions, imperialist foreign policy, so-called "McCarthyite" fear-mongering, massive propaganda campaigns, and other such devices that created a centerright consensus in the $1950 \mathrm{~s}$, the labor and cooperative movements were severely damaged. It was essentially a war of big business and conservative Republicans against the social and political legacy of New Deal America, a war in which centrist politicians and even liberal Democrats were complicit, due in large part to the supposed exigencies of the Cold War. ${ }^{182}$

Nevertheless, all was not quiet on the worker-cooperative front. In Washington and Oregon a number of large cooperatives had been and were still being organized; these were the plywood co-ops

${ }^{180}$ Knapp, The Advance of American Cooperative Enterprise, 346, 347, 373.

${ }^{181}$ Curl, For All The People, 187.

182 See Elizabeth Fones-Wolf, Selling Free Enterprise: The Business Assault on Labor and Liberalism, 1945-60 (Urbana: University of Illinois Press, 1994). 
discussed in the last chapter. They would go on to become the longest-lived cluster of cooperatives in the United States, lasting from the 1920s to the early 2000s (although dwindling in later years). The first one was called Olympia Veneer, organized in 1921: a bank loan of $\$ 25,000$ was secured, and 125 shares of equity were sold at $\$ 1000$ each to loggers, carpenters, and mechanics, in order to finance construction. The business did well, and shares were sold at a high price to outsiders. Soon the worker-owners were earning oneand-a-half times the pay of employees in conventional enterprises, due to their higher productivity. Over time the co-op degenerated into something like a capitalist corporation, since non-member employees were hired and non-workers could buy shares. By 1952, a thousand non-owners were employed and the original plant had been sold to a conventional lumber company; in 1954 Olympia was sold to U.S. Plywood Corporation. ${ }^{183}$

More plywood co-ops were formed just before World War II, and 21 were organized between 1949 and 1956. Over the course of their lifetime, the size of their workforces would be between 60 and 500. In the 1940s and '50s the cooperatives accounted for 20 to 25 percent of total production capacity in the industry; in later decades their relative share declined as many more conventional firms were created and almost no new co-ops. On the whole, though, they continued to perform very well, as well as or better than their conventional competitors even during severe slumps in the industry. Their decline in the 1990s did not reflect problems with their cooperative organization but rather the overall decline of the regional industry. Conventional mills succumbed too. ${ }^{184}$

Why were the plywood co-ops so successful? One reason is that they were formed in the growth period of a major new industry. ${ }^{185}$ As stated above, the cultural origins of the cooperators surely played a role too: the Scandinavian people-who settled the Pacific Northwest-have traditionally sought cooperative solutions to

\footnotetext{
${ }^{183}$ Dow, Governing the Firm, $50 \mathrm{ff}$.

${ }^{184}$ Ibid.

${ }^{185}$ Gunn, Workers' Self-Management in the United States, 104.
} 
problems. Also, the region had already had much experience with consumers' and producers' co-ops. These last two reasons point to the importance of a "collective memory," a cultural memory, to the resilience of an oppositional culture. ${ }^{186}$ Examples are legion: the Knights of Labor was defending an artisanal, pre-industrial, Jeffersonian-republican ethos; the Italian working-class anarchists in Northeast urban communities at the turn of the twentieth century had recently emigrated from rural areas in Italy with rich communal traditions they carried over to the New World, and which served as a foundation for radical opposition to industrial capitalism; ${ }^{187}$ in the 1960s, SNCC had success organizing a civil rights movement in the South because it tapped into local traditions of participatory democracy, religion, empowerment through music and ritual, and small-town mutual respect and dialogue. ${ }^{188}$ Even in the 1990s, Mayans in North Carolina who had recently emigrated from Guatemala waged a long battle against their employer Case Farms, nourished and encouraged by their collective memories of rural community, mutualism, agricultural cooperation, and immersion in the Catholic church. ${ }^{189}$ All these dissidents derived their strength from the "radicalism of tradition" as it came into conflict with industrial society. ${ }^{190}$

That fact would seem to have a discouraging implication with respect to the viability of contemporary and future struggles against capitalism, namely that they will not be very "resilient" because, in

${ }^{186}$ T. J. Jackson Lears, "Power, Culture, and Memory," in In Search of the Working Class: Essays in American Labor History and Political Culture, ed. Leon Fink (Chicago: University of Illinois Press, 1994), 117.

${ }_{187}$ See Paul Avrich, Sacco and Vanzetti: The Anarchist Background (Princeton, New Jersey: Princeton University Press, 1991).

${ }_{188}$ Charles M. Payne, I've Got the Light of Freedom (Los Angeles: University of California Press, 2007).

${ }^{189}$ Leon Fink, The Maya of Morganton: Work and Community in the Nuevo New South (Chapel Hill: The University of North Carolina Press, 2003).

${ }^{190}$ Craig Calhoun, "The Radicalism of Tradition," American Journal of Sociology 88, no. 5 (1983): 886-914. 
many parts of the world, the possibility no longer exists of grounding them in "tradition," a "collective memory," "precipitates of past historical experience." 191 These precipitates, after all, have largely been erased by late capitalism. However, I think the conclusion is unwarranted. As will be evident from the following chapter, I think a good way to conceptualize radical movements is by dividing them into those that proceed in large part from the "radicalism of tradition" and those that do not obviously draw sustenance from past historical experience but instead grow out of mature capitalism itself. These two categories are of course merely ideal-types, and actual social movements might not always fall clearly under one or the other. But examples of the "non-traditional" kind of movement would be the anti-war, the feminist, the environmental, and the Black Power movements of the late 1960s. Currently, the vast global movement symbolized by the World Social Forum is, on the whole, a clear case of the "mature" sort of anti-capitalist radicalism, the unequivocally progressive sort (as opposed, for instance, to the Knights of Labor, which was in some respects reactionary). These latter-day movements have been quite resilient, some lasting decades and instigating major changes in culture and politics.

Karl Marx had little to say about the traditional, "primitive" sort of radicalism, ${ }^{192}$ and in fact the utilitarian, Enlightenment-derived, rationalistic and economistic bias of Marxism makes this theory not a wholly adequate framework for understanding them. At least as a sweeping theory, historical materialism tends to downplay the significance of "culture" and cultural residues, just as it has little interest in the psychological motivations that actually guide actors, emphasizing instead the latters' structural locations in the economy and the utilitarian interests that these locations dispose them to

${ }^{191}$ Lears, "Power, Culture, and Memory," 117.

${ }^{192}$ Eric Hobsbawm, Primitive Rebels: Studies in Archaic Forms of Social Movement in the $19^{\text {th }}$ and $20^{\text {th }}$ Centuries (Manchester, England: The University Press, 1959). 
pursue. ${ }^{193}$ This framework has its deficiencies, but it is more appropriate to the analysis of "modern" radical movements than "archaic" ones. In particular, it is a powerful tool for interpreting, first, "modern" struggles between capital and labor, with regard to which considerations of culture and tradition are decidedly subordinate to the objective facts of structural location, ${ }^{194}$ and second, the future evolutionary transition to a post-capitalist society. It is precisely the latter that Marx intended his theory to explain. Archaic cultural residues will be less relevant to this evolution, which, if it happens, will be propelled overwhelmingly by the economic conditions of late capitalism.

In another sense, however, "collective memory" has always been and will always be essential to every oppositional movement, inasmuch as the movement has to educate itself, remember its past experiences and learn from them, maintain and expand on its institutional innovations, build up economic, social, and cultural bases of resistance. The plywood cooperators came from a subculture that had already experimented with consumers' and producers' co-ops, which made their new venture that much easier.

${ }^{193}$ Cf. Axel Honneth, The Struggle for Recognition: The Moral Grammar of Social Conflicts (Cambridge, MA: The MIT Press, 1995), 145-151. On another level, though, Marxism as a set of research programs is perfectly compatible with - indeed, tends to encourage - an emphasis on the concrete experiences of collective actors, as evidenced by, e.g., E. P. Thompson's The Making of the English Working Class, David Montgomery's The Fall of the House of Labor: The Workplace, the State, and American Labor Activism, 1865-1925 (New York: Cambridge University Press, 1987), and Barrington Moore's The Social Origins of Dictatorship and Democracy: Lord and Peasant in the Making of the Modern World (Boston: Beacon Press, 1966), not to mention Marx's own Eighteenth Brumaire of Louis Bonaparte and The Civil War in France.

${ }^{194}$ We should not forget, though, as some revisionist historians are wont to do, that class structures have always been of central importance even to the old "tradition-derived" struggles. It is precisely the industrial capitalist class structure that artisans, petty bourgeoisie, peasants and others have fought against, while drawing on their cultural heritage. 
Another reason for their success is that the first few co-ops provided a "template" that later organizers could use. This, too, is an important lesson for contemporary cooperators.

Another lesson lies in the fate of many of these cooperatives: due in large part to their success, they degenerated into semi-capitalist corporations. Some of them were actually sold to conventional enterprises, but apparently all of them used hired, non-member labor much of the time. As stated in chapter two, they did not want to increase the number of worker-owners by creating new shares, because that would have entailed a loss of income for the current members. So the firms that wanted to expand simply hired employees who were not allowed to participate in decision-making and had vulnerable, often temporary jobs. They were effectively second-class citizens in the plants - and they sometimes constituted almost 50 percent of the workforce. This clearly interfered with a culture of cooperation. In fact, what sometimes happened was that when a member retired, his share was not sold to a new worker but instead bought back by the firm, so that each member would have a somewhat higher annual income. The result was that the membership, i.e., the class of owners, gradually shrank as the class of hired labor expanded. For example, during the first five years of Olympia's operation (1923 to 1928), 100 non-members were hired, as the number of worker-owners dropped from 118 to $92 .{ }^{195}$

This capitalist mentality was evidenced also in the fact that these co-ops did not participate in cooperative social movements and were formed purely for the sake of providing employment to members. They had no strong ideological commitment to cooperation; they rarely even linked up with one another for political, economic or ideological reasons. Each enterprise was simply "one big family" (with the exception of the hired labor) united against a hostile outside world.196 As mentioned earlier, therefore, it is important that co-ops maintain a connection with social movements if their cooperative

\footnotetext{
195 Dow, Governing the Firm, 51.

${ }^{196}$ Gunn, Workers' Self-Management, 106.
} 
identity is not to erode. No great social change will happen if cooperatives simply speckle the economic landscape atomistically, even if there are quite a few of them; they have to actively spread their ideology, spawn new co-ops, maintain ties with the labor movement, fundraise continually, help agitate politically for grants and favorable legislation, look to progressive social experiments being undertaken in other parts of the world and learn from them or contribute to them. Besides, it is likely that the more connections they have with each other, the smaller is the possibility that they will fail economically.

The next great wave of cooperatives after the 1930s adhered to some of these principles, and was in any case the very antithesis of what the plywood mills represented. I'm referring to the movements of the 1960s and '70s. The perennial question arises: what caused these movements? At first glance they seem to have appeared out of nowhere. That is not true, of course; rumblings in the 1950s and earlier anticipated them. In the South, black activists in the 1940s and '50s were establishing connections with each other, testing the limits of repression, registering voters (voter registration increased fourfold, eightfold, tenfold even by the early 1950s) $;{ }^{197}$ the NAACP became increasingly active prior to and after Brown v. Board of Education, and its membership expanded. Conflicts escalated between whites and blacks as the latter grew in collective confidence. At the same time, urban centers in the North were incubating the counterculture, notably Greenwich Village and San Francisco, where artists, students, intellectuals, and dissidents of all sorts came together in loose communities. In the late 1950s and early 1960s, these movements reached a critical mass and exploded into the national spotlight.

Ultimately, the explanation for what was happening lies mainly in the advance of the productive forces and their bursting the shackles of certain conservative production relations. In the South, for example, tractors appeared during the First World War; later,

${ }^{197}$ Payne, I've Got the Light of Freedom, 25, 26. 
flame cultivators cleared land more cheaply than laborers did; a cotton harvester came into use during the 1940s, which did the work of forty cotton-pickers. In short, cotton production was being mechanized. At the same time, "competition from synthetics and cheap foreign cotton made cotton a less valuable crop." Plantations needed fewer and fewer laborers, and so there was less economic need to control blacks, "either through the near-peonage of sharecropping or through violence." Millions of them migrated to Northern cities, while the rest tended to become more socially assertive - not least because the rise of radio and television, as well as the mass mobilization for the Second World War, lessened their isolation from the rest of the world, encouraging activism to enact freedom and equality. Northern cities became more populous and diverse, which fostered creativity and dissent, as Southern cities became more overtly conflict-ridden. ${ }^{198}$

The movements that sprouted from this soil, including the civil rights, anti-war, women's, students', environmental, and anti-nuclear movements, translated their concern with freedom and democracy into organizational arrangements that revolved around the "collective." In a broad sense, a collective is just a small group that embodies participatory democracy; it is a form that can be adapted to many uses, from education and childcare to art or law. It was nearly ubiquitous in the 1960s: Freedom Schools, informal leadership committees, law collectives, communes, underground newspapers, cooperative housing, "food conspiracies," free medical clinics in Chicago and Oakland administered by the Black Panthers, the latter's Liberation Schools, free breakfast and clothing programs, free stores in San Francisco, music and art groups, "free universities" offering unorthodox courses, etc. And there were hundreds of worker collectives, and even more consumer co-ops.

John Curl summarizes the evolution of the sixties' worker collectives:

198 Payne, I've Got the Light of Freedom, 17, 19. See also Frances Fox Piven and Richard Cloward, Regulating the Poor: The Functions of Public Welfare (New York: Vintage Books, 1971), chapter seven. 
The earliest collective businesses were mostly connected with radical communication media: presses, bookstores and film. This reflected the explicitly political movement from which they emerged. They were followed by food-related cooperatives in the late 1960s, and artisan/industrial collectives and cooperatives beginning around 1970 both in urban and rural areas. These differed from earlier American industrial cooperatives and co-op stores mainly in that they chose worker control through the collective consensus decision-making system, rather than the majority-rule managerial system predominant since the early $19^{\text {th }}$ century. ${ }^{199}$

I cannot discuss the sixties and seventies in great detail here. Much of the history is common knowledge or is easily accessible. The rise and partial fall of food co-ops is illustrative and perhaps most worth looking at: "Of all the countercultural organizations, they became the most interconnected, the most developed ideologically and...had the most far-reaching effects." ${ }^{200}$ Between five and ten thousand of them were organized in the late sixties and seventies, at the end of which decade they had an annual volume of about $\$ 500$ million. ${ }^{201}$ Some were controlled only by their workers, others by their workers and customer-members. Many began on college campuses but spread to working-class and middle-class neighborhoods as food prices skyrocketed in the 1970s, rising almost 50 percent between 1972 and 1976. The cooperatives' goal was, first, to provide healthier, less expensive food to their communities, and second, to create a radical alternative to the dominant system. The movement developed dozens of cooperative warehouses around the country to help supply the stores, since most co-ops could not buy in

\footnotetext{
${ }^{199}$ Curl, For All The People, 209, 210.

${ }^{200}$ Ibid., 212.

${ }^{201}$ Daniel Zwerdling, "The Uncertain Revival of Food Cooperatives," 90. The following information comes from Zwerdling's article and Curl, 212218.
} 
sufficient bulk for established wholesalers to do business with them. Trucking collectives helped connect the system of alternative wholesalers, co-ops, and regional federations on both coasts and in the Midwest.

When one considers the forces against them, it is remarkable how much the cooperatives accomplished. As always, the main obstacle was lack of money. Sometimes organizers had to knock on doors in their communities to fundraise before creating a store, or hold benefits such as dances. When the co-op got started it was often able to sell some food (not all) more cheaply than supermarkets because its members were not concerned with making a profit, and their business had little overhead. Some customers would be recruited for volunteer labor, but most importantly, workers paid themselves very low wages. Without this extreme "selfexploitation," most co-ops could not have lasted long or offered food at such low prices.

The food co-op movement, insofar as it can be called a movement, declined in the late 1970s. Cooperatives could not compete with corporate supermarkets at selling processed foods or meat, or having a high volume of products. They became specialty stores that customers would patronize to buy natural and wholesome foods before skipping over to the local supermarket to buy everything else. Cooperators found that in order to remain in business they had to expand-which meant compromising their principles and led to bitter ideological fights. Even if they were able to expand, which they usually were not, they were often still too small to remain financially viable for long, and with the low wages, workers "burned out" after a few years. There was also a chronic shortage of business experience. Financial problems were sometimes not taken seriously until it was too late. Some of these failures could have been mitigated had more cooperative networks been established across the country, but participants in the movement had too many different ideologies and goals to work together in a sustained way. Some had political agendas, others were committed only to running a store. "The co-ops in Minneapolis," said one participant, "are very isolationist." This was true almost everywhere. 
Surveying the terrain of New Left movements in the sixties and seventies, one is led to several conclusions. Most of these movements seem to have gone wrong in similar ways, due to similar causes. State violence and repression were instrumental in some cases, especially regarding those few movements, such as Black Power, that explicitly challenged the class structure. More widespread in its counterproductiveness was ideological sectarianism. The bitter factional infighting that erupted in the late sixties and early seventies drained energy from networking and coordinating dissent. Often participants could not agree on their overall aims, or even their immediate aims. Even more importantly, the movements that attempted to create such alternative institutions as cooperatives and communes suffered from an inevitable lack of capital; in the end, the organizations that survived, whether in the media-like the Village Voice and Rolling Stone-or in the food industry, had to follow the rules of the dominant system. Idealism and inexperience lost out to pragmatism and business acumen.

On a deeper level, the fatal flaw in the New Left was that it did not set out to change the dominant mode of production in any comprehensive or competent way. One cannot have a true "social revolution" without radically transforming the class structure, which is the foundation of society's institutional structures in general. The sixties' movements, by and large, focused on culture and politics while neglecting the economy, thus vitiating their long-term goals. They were more interested in "sexy" things like culture, ideology, and politics than the hard work, the decades-long work, of building up a new economy. Of course, this could not have been done anyway; structurally it was impossible at that time, and even now it will be decades before the transition from capitalism to a more cooperative mode of production, if it takes place at all, will reach a very visible level. Nevertheless, the absence in the 1960s of an alliance between the labor movement and the New Left - indeed, the 
outright mutual hostility ${ }^{202}$ - suggests the latter's "superstructural" nature, as it suggests the former's bureaucratic ossification and conservatism under George Meany and the old guard.

The fate of the New Left shows that the way to a new society does not lie with sectarian ideologizing. It lies with protracted economic evolution, coordination of sustained economic and political struggles, the slow accumulation of financial and human resources-nothing so culturally fixated and impatient as the movements of the 1960s. They were a product not of the impending demise or decrepit nature of capitalism, as many hoped, but of transformations in production relations and technologies (most obviously in the South), population movements, the complex of federal, state, and local housing and tax policies that fostered "white flight" to the suburbs and left inner cities to rot, ${ }^{203}$ the spread of media that connected distant regions to an unprecedented degree, the partly resultant elevation of the problem of poverty into the national consciousness, the U.S.'s waging of an unpopular war in Vietnam, and many other circumstances.

All this time, mainstream cooperatives were making quiet progress. Credit unions, for example, which had been given legal foundations in the early decades of the century, spread after World War II. By 1969 there were nearly 24,000 credit unions, and a decade later they had 43 million members. Housing co-ops, which date to the beginning of the century, expanded in cities during the 1960s, many of them partly financed by the Department of Housing and Urban Development. Agricultural cooperatives (in marketing, buying and selling, etc.) continued to thrive and merge into everlarger units, even as the number of farmers shrank. In 1955 there

${ }^{202}$ See Nelson Lichtenstein, State of the Union: A Century of American Labor (Princeton: Princeton University Press, 2002), chapters four and five. ${ }^{203}$ See, e.g., Robert O. Self, American Babylon: Race and the Struggle for Postwar Oakland (Princeton: Princeton University Press, 2003) and Marxism and the Metropolis: New Perspectives in Urban Political Economy, eds. William Tabb and Larry Sawers (New York: Oxford University Press, 1984). 
were 8100 farmer cooperatives with 7.6 million members; in 1979 there were 7500 cooperatives with fewer than six million members. Most rural inhabitants were no longer independent farmers but wageearners for agribusiness, belonging to the rural proletariat. As for worker co-ops, John Curl estimates that their U.S. membership reached its peak in 1979 with about 17,000 people. There were 750 to 1000 small co-ops and a number of larger ones, including 18 plywood co-ops and a reforestation cooperative called Hoedads with 300 members. $^{204}$

The Reagan years were not kind to cooperatives, as they were unkind to the whole labor movement and in fact to oppressed people everywhere in the world. It was a terrible decade, the first full decade of neoliberal attacks on the global population. Still under the influence of conservative Meanyite traditions, the U.S. labor movement remained ambivalent to worker-ownership as manifested in employee buyouts, ESOPs, and cooperatives, opposing the blurring of the line between employees and management. Ever since the AFL had endorsed collective bargaining and rejected worker cooperatives in the late nineteenth century, this had been the standard line. It began to change in the late 1970s as union officials and local communities experimented with employee buyouts as ways of preventing plant shutdowns and saving jobs. ${ }^{205}$ But in most cases the traditional adversarial relations between workers and bosses remained despite majority employee-ownership, and often buyouts could not prevent the failure of a plant anyway. Stock ownership plans have become increasingly popular since the 1980s, but usually they have little in common with worker cooperatives, since employees typically do not control the firm even if they own most of its stock. Arguably they are of more use to management than to

\footnotetext{
${ }^{204}$ Curl, For All The People, 235-241.

205 The most famous case is that of the 1977 steel mill closing in Youngstown, Ohio, which led to the employees' (failed-or foiled) attempt to buy the factory and turn it into a worker cooperative. See Staughton Lynd, Fight Against Shutdowns: Youngstown's Steel Mill Closings (San Pedro, California: Singlejack Press, 1982).
} 
ordinary workers, being ways of raising capital and of giving employees a direct stake in the company's success (which is supposed to motivate them to be productive). ${ }^{206}$ Gar Alperovitz may be right, however, that in the long run ESOPs have great transformative potential, as employees demand more control over the companies they own. ${ }^{207}$

Recessions and a hostile political environment led to the relative decline of consumer and worker co-ops in the 1980s and, to a lesser extent, the 1990s, but in some areas in the latter decade co-ops began to come together in federations or sponsored the creation of supporting institutions. San Francisco's Network of Bay Area Worker Cooperatives, founded in 1994 to connect dozens of co-ops, is an exemplar of that trend, and it continues to spawn new businesses and affiliate with others. The National Cooperative Bank, chartered by Congress in 1978, provided assistance to cooperatives throughout these years; its total assets as of December 31, 2012 were $\$ 1.7$ billion. ${ }^{208}$ Unfortunately it does not often provide loans to worker cooperatives, focusing instead on consumer co-ops, housing, ESOPs, community development corporations, and sometimes even fast-food chains like Dunkin' Donuts (which qualifies as a business cooperative under NCB's definition).

Recently the prospects for cooperatives in all spheres, all over the world, have become brighter than ever. The United Nations and affiliated institutions have repeatedly proclaimed that cooperatives are a crucial component of the plan to meet the Millennium Development Goals by 2015. From dairy cooperatives in

${ }^{206}$ William Foote Whyte et al., Worker Participation and Ownership: Cooperative Strategies for Strengthening Local Economies (Ithaca: ILR Press, 1983), chapter five.

${ }^{207}$ Gar Alperovitz, America Beyond Capitalism, 81-89. Over three thousand ESOP companies are majority-owned by workers, and 40 to 50 percent of these have given voting rights to employees.

${ }^{208}$ National Consumer Cooperative Bank, "Financial Update from the CFO," http://www.ncb.coop/default.aspx?id=4074 (accessed April 30, 2013). 
Bangladesh, water cooperatives in Bolivia (to give people access to safe drinking water), and a revitalized consumer cooperative sector in Russia, to tenant takeovers of abandoned housing in New York City ${ }^{209}$ and cooperative care of the elderly and disabled in Wisconsin and New York, the movement is making life livable for millions and spreading an anti-capitalist ethos. Indeed, as stated in this book's Introduction, we seem to be in the early stages of a renaissance unlike any in the history of cooperativism.

As will be clear from the following chapter, this renaissance is not some accidental or inexplicable thing. Forty years of savage neoliberal assaults on workers' rights have decimated civil society and discredited conventional approaches to fighting capitalist power. The old paradigm of bureaucratic business unionism, a narrow focus on wages and collective bargaining, and reluctance to fight for broader issues of social justice has failed catastrophically. New strategies are desperately needed and have begun to be pursued, even by such former strongholds of conservatism as the AFL-CIO. Unions that used to follow the motto "We'll get it done ourselves" are now allying with women's groups, immigrant organizations, environmental groups, and community groups of all kinds to fight for mutually beneficial goals like environmental protection, immigrant rights, a higher minimum wage, and improved public education. ${ }^{210}$ The innovative strategy of "minority unionism" is spreading: rather than organizing a majority of workers at one business and then holding a vote for union recognition, a minority of workers at multiple businesses are organized to engage in militant, public actions that dramatize grievances, galvanize political action, and hopefully force employers to make concessions while attracting

\footnotetext{
209 Cooperative ownership is the most common form of apartment ownership in New York. Johnston Birchall and Lou Hammond Kettilson, "Resilience of the Cooperative Business Model in Times of Crisis," 7.

${ }^{210}$ Steven Greenhouse, "AFL-CIO Has Plan to Add Millions of Nonunion Members," New York Times, September 6, 2013.
} 
more workers to unionism. ${ }^{211}$ Recent strikes at Walmart, in the fastfood industry, and for a $\$ 15$ federal minimum wage have followed this model. Progressive unions are reaching across national borders to create transnational alliances - a long-delayed necessity in this age of globalization. New models are emerging of "regional powerbuilding," the construction of durable coalitions between unions, local labor councils, progressive business groups, and other civil society organizations. ${ }^{212}$ In this context of free-wheeling experimentation to address labor's woes, the spread of cooperativism and worker ownership is one of the most exciting developments. The sophistication of current projects is striking: in particular, institutions have learned the lesson that nothing is more important than to make connections with each other to birth new co-ops. ${ }^{213}$

For instance, the United Steelworkers union and Mondragon announced in October 2009 that they were collaborating to establish manufacturing cooperatives in the U.S. and Canada, an agreement that USW president Leo Gerard called "a historic first step towards making union co-ops a viable business model." ${ }^{214}$ In March 2012, the USW, Mondragon, and the Ohio Employee Ownership Center jointly

${ }^{211}$ Josh Eidelson, "Walmart Workers Model 'Minority Unionism,"” The Nation, December 11, 2012.

${ }^{212}$ Amy Dean and David Reynolds, A New New Deal: How Regional Activism Will Reshape the American Labor Movement (Ithaca: ILR Press, 2009). There is a growing literature on the new progressivism of U.S. unions and the necessity for it. See, e.g., Tamara Kay, NAFTA and the Politics of Labor Transnationalism (New York: Cambridge University Press, 2011), which traces this progressivism to the shock of NAFTA. Bill Fletcher Jr. and Fernando Gapasin, Solidarity Divided: The Crisis in Organized Labor and a New Path Toward Social Justice (Berkeley: University of California Press, 2008) is a thoughtful analysis of the crisis in the labor movement and possible solutions to it.

${ }^{213}$ For examples, see Luc Labelle, "Development of Cooperatives and Employee Ownership, Quebec-Style."

${ }^{214}$ Carl Davidson, “'One Worker, One Vote:' US Steelworkers to Experiment with Factory Ownership, Mondragon-Style," SolidarityEconomy.net, October 27, 2009. 
announced the publication of their detailed template for union coops, which sets out an organizational structure that can be replicated by other unions interested in starting co-ops as a way to save jobs and communities. The template is based on Mondragon's structure but with the key innovation that a Union Council (in place of Mondragon's Social Council) is empowered to collectively bargain with the management team on such matters as compensation and working conditions. That is, worker-owners elect a Board of Directors that appoints a management team to oversee the business's day-to-day operations and to engage with the Union Council on matters pertaining to employee rights and welfare. All the members of these bodies are required to be worker-owners themselves. The template, which also includes guidelines on ownership structures, financing, education, training, etc., is flexible enough to be appropriate for businesses of from ten workers to thousands of workers. $^{215}$

The USW, along with SEIU and other unions, is already involved in a number of cooperative initiatives. For instance, it is helping to launch the Pittsburgh Clean and Green Laundry Cooperative, a new industrial laundry that will employ a hundred people. "Under the union-cooperative model," Amy Dean writes, "the laundry's employees would be able to join the union of their choice, and the jobs offered at the plant would provide a living wage, benefits, and a collective bargaining agreement. As worker-owners, the employees would also gain equity in the business." 216 Pennsylvania's Steel Valley Authority, which has been integral to the project, describes its ambitions as follows:

${ }^{215}$ Rob Witherell, Chris Cooper, and Michael Peck, "Sustainable Jobs, Sustainable Communities: The Union Co-op Model," at assets.usw.org/ourunion/coops/The-Union-Co-op-Model-March-26-2012.pdf (accessed May 15, 2013).

${ }^{216}$ Amy Dean, "Why Unions Are Going Into the Co-op Business," Yes! Magazine, March 5, 2013. 
It would be our intent to create worker ownership initiatives across the Pittsburgh region and examine the potential for expanding this initiative state and region-wide, and over time, explore opportunities for national replication. In order to accomplish this, the SVA is exploring the development of a dedicated center that provides technical assistance, a revolving loan fund that provides early stage capital for new co-op businesses, and a training program that provides specialized training for company leadership... ${ }^{217}$

All these ideas are taken, in part, from Mondragon, which is collaborating with the SVA.

Another example of the USW's activism is its support of the Cincinnati Union Cooperative Initiative, which is developing a railway manufacturing co-op, a co-op for retrofitting buildings for energy efficiency, and a "food hub" called Our Harvest that allows institutions "to buy produce that is grown, harvested, and packaged by worker-owners." Our Harvest, which is in partnership with the United Food and Commercial Workers union, is already in operation: food is grown on a 30-acre farm in an urban neighborhood, though plans are underway to get a thousand acres' worth of production going. ${ }^{218}$

As Rob Witherell of the USW notes, union-affiliated projects like these are springing up all over the country, from Seattle to New York. "One of the nice problems we have," he says, "is trying to keep track of it all.",219 This "problem" is a happy indication that the U.S. labor movement, in the footsteps of Latin America's, Canada's, and Europe's, is finally starting to take seriously the enormous potential that cooperatives have as both job-saving devices and

217 Steel Valley Authority, "Pittsburgh Clean and Green Project," http://www.steelvalley.org/building-sustainable-communities/pittsburghcleangreen-project (accessed May 20, 2013).

${ }^{218}$ Amy Dean, "Why Unions Are Going Into the Co-op Business."

${ }^{219}$ Steve Dubb, "Interview with Rob Witherell: Representative, United Steelworkers," Truth-Out.org, April 9, 2013. 
means of pushing society in a progressive direction. Not since the 1880 s, in fact, have mainstream American unions been so actively involved in either worker cooperativism or what has come to be called "social justice unionism" (or "social movement unionism"). ${ }^{220}$

One of the success stories that has inspired this recent flurry of activism is the Evergreen Cooperative Initiative in Cleveland, Ohio. So successful has it been that in 2010 it was featured on NBC Nightly News, which glowingly reviewed its efforts to revitalize an impoverished community on the east side of the city; it has also been the subject of articles in the Economist, Business Week, the Nation, Time, and dozens of less prominent media venues. The reason for all this hype is that it has provided a new and ambitious model for reversing economic decline in a blighted area of the Rust Belt. The project came to fruition in 2008 when several local institutions (including the Cleveland Foundation, University Hospitals, Case Western Reserve University, and the municipal government) teamed up with the Ohio Employee Ownership Center and the Democracy Collaborative at the University of Maryland to establish a network of worker-owned businesses modeled on Mondragon's federated structure. The goal was, and is, to create ten co-ops and 500 livingwage jobs for local residents. With the help of millions of dollars in grants, three businesses had been created as of 2013: Evergreen Cooperative Laundry, Evergreen Energy Solutions, and Green City Growers Cooperative (supposedly the largest urban food-producing greenhouse in the country). Technologically these are cutting-edge enterprises, committed to being the greenest firms in their sectors. They are also very profitable, in part because they've attracted the business of hospitals and other local "anchor institutions" that are trying to reduce their carbon footprint (and keep their money within the community). To help start new co-ops, each of the businesses is required to pay ten percent of its pre-tax profits into a Cooperative

\footnotetext{
${ }^{220}$ For more illustrations of the rapprochement between cooperatives and unions, see Dan Bell, "Worker-Owners and Unions: Why Can't We Just Get Along?"
} 
Development Fund - a practice that is modeled, again, on Mondragon. ${ }^{221}$

Perhaps as noteworthy as these glimmers of a new movement is the fact that worker cooperatives are faring comparatively well in our stagnant economy, on average better than capitalist businesses. An ILO report in 2009 concluded that "Financial cooperatives remain financially sound; consumer cooperatives are reporting increased turnover; worker cooperatives are seeing growth as people choose the cooperative form of enterprise to respond to new economic realities." ${ }^{222}$ Cooperative banks, not being driven purely by the profit-motive, had little incentive to give risky loans; 2008 was in fact a record year in many respects for credit unions, some of which are among the largest banks in the world. Regarding other types of cooperatives, there has lately been an increase in their formation rates, and, as noted earlier, they have tended to last longer than conventional businesses. $^{223}$

A 2012 study by the European Confederation of Worker Cooperatives, Social Cooperatives and Social and Participative Enterprises reaches similar conclusions. The record has not been uniformly positive across Europe, but in general cooperatives have been more resilient than conventional enterprises. Their members mostly attribute this fact to the "participation of members in the management of the cooperative, the build-up of reserve funds, the connection with territorial needs and the participation of the community, the capacity to organise and follow-up business transfers to employees, mutual aid and horizontal groups and consortia among cooperatives. In particular, the establishment of horizontal groups and consortia is considered by members as being an important

\footnotetext{
${ }^{221}$ The Evergreen website, at http://evergreencooperatives.com/, has links to many articles describing how the model works. See also Gar Alperovitz, Thad Williamson, and Ted Howard, "The Cleveland Model," The Nation, March 1, 2010.

${ }^{222}$ Birchall and Kettilson, "Resilience of the Cooperative Business Model in Times of Crisis," 2.

${ }^{223}$ Ibid., 29.
} 
instrument to support innovation and competitiveness for small and medium sized worker and social cooperatives." ${ }^{224}$ The number of worker cooperatives in the UK actually increased during the crisis, from 373 in 2007 to 541 in 2011. In March 2013 the Financial Times had an article titled "Economic crisis spawns co-op revival," which observed that the total number of cooperatives had risen by 23 percent since 2008, about the same rate as their growth of revenue. ${ }^{225}$

One of the lessons of such developments is that as oppressed people and their advocates find traditional avenues of reform closed to them, they will be forced to invent revolutionary new solutions such as worker cooperatives. This is what the Latina immigrants in Natural Home Cleaning and Home Green Home Natural Cleaning have done, as well as those involved in the emerging New York City Co-op Network, ${ }^{226}$ and the Evergreen cooperators and many others. They have all been stymied in their attempts to seek help through conventional channels. Economic outcasts like these will continue for decades to network with each other outside the mainstream, accumulating resources on behalf of cooperativism, building up an alternative civil society alongside a decaying capitalist order. The system itself will drive them to these extremes; it will produce its own gravediggers as it collapses in old age. And the long, tragic history of cooperatives will finally be consummated: it will be rescued and celebrated as a glorious harbinger.

\footnotetext{
${ }^{224}$ Bruno Roelants et al., The Resilience of the Cooperative Model (CECOP-CICOPA Europe, 2012), 14, http://www.cecop.coop.

${ }^{225}$ Andrew Bounds, "Economic crisis spawns co-op revival," Financial Times, March 15, 2013.

${ }^{226}$ Michael Johnson, "A Network of Cooperatives Gets Organized in New York City: Low-income and immigrant workers well-represented," Grassroots Economic Organizing (GEO) Newsletter, vol. II, issue 5 (2010), http://www.geo.coop/node/435 (accessed May 18, 2010).
} 



\section{CHAPTER FOUR MARXISM AND THE ALTERNATIVE ECONOMY}

The death of Marxism has been announced so many times that it might seem anachronistic to reconsider Marx's ideas yet again. In the twenty-first century haven't we moved beyond Marxism? The answer, it seems, is no. For one thing, in recent years even the mainstream media has suggested that the ghost of Marx is haunting the world. Articles are published with headlines like "Why Marx was Right",227 and "Marx's Revenge: How Class Struggle Is Shaping the World," 228 and mainstream economists like Paul Krugman and Nouriel Roubini invoke Marxism to explain capitalism's current crisis. Radical thinkers such as David Harvey and Richard Wolff have become academic celebrities, and magazines like Monthly Review and Jacobin are becoming more popular. In fact, the Pew Research Center reported in 2011 that among Americans aged 18 to 29,49 percent have a positive view of socialism whereas 46 percent have a positive view of capitalism. ${ }^{229}$ It seems, then, that reports of Marx's death have been greatly exaggerated.

It is worth asking why Marxism is so resilient. On the most basic level, the answer is that class struggle is indeed of central and perennial importance to human life. Since the emergence of social classes thousands of years ago, individuals' and groups' access to resources has been determined primarily by their positions in particular relations of production (or a "mode of production") - and of course access to resources is of unique importance to life, since it essentially determines one's ability to survive and to influence what happens in society. The way that economic production has worked since class structures emerged is that certain classes of people have,

${ }^{227}$ Francis Wheen, Financial Times, March 27, 2011.

${ }^{228}$ Michael Schuman, Time, March 25, 2013.

${ }^{229}$ Alexander Eichler, "Young People More Likely To Favor Socialism Than Capitalism: Pew," The Huffington Post, December 29, 2011. 
through various methods of "hard" and "soft" power, forced others to work for them, or rather to produce a surplus that can be appropriated by the privileged or those with power. Whether people have been aware of "forcing" others to work-or of being forced to work - is irrelevant; the point is that the system has functioned in such a way that some people have had to be slaves, serfs, wagelaborers, etc., while others have been slaveowners, landed aristocrats, capitalists, etc.-i.e., have profited off others' labor (due to asymmetrical power relations). Exploiters and exploited have thus confronted each other in a perpetual struggle, sometimes implicit and sometimes explicit, to have more power and resources. The profound explanatory power of this analytic framework explains why academic Marxism has for decades been relatively prominent even in a capitalist society.

Incidentally, a corollary of this emphasis on class struggle and class interests is equally valid: at least if explanation is one's goal, it is more fruitful to analyze "social being" than "consciousness." The former is more fundamental than the latter, in part because consciousness tends to be a sublimation of social being. That is to say, ideologies, "discourses," subjective identities, thoughts and conceptions of all kinds are conditioned by such non-discursive things as economic realities, institutional imperatives (the need to follow the rules of given social structures), physical environments, and the basic necessities of biological survival to a far greater degree than the latter are conditioned by the former. This is true of both individuals and collectivities. For example, people in a particular social category will tend to have beliefs that legitimate their economic interests and institutional roles. Slaveowners may well believe that slavery is moral or divinely ordained; intellectuals will probably think that ideas or "discourses" are of tremendous importance; ${ }^{230}$ capitalists will be prone to thinking that capitalism and greed are natural and good. But even if some people manage to

${ }^{230}$ For critiques of postmodern idealism, see my Notes of an Underground Humanist (Bradenton, Florida: Booklocker, 2013). 
be more mentally independent than the majority, that doesn't matter much, because there are still overwhelming pressures for their behavior to conform to social structures and institutional norms. And these are situated in a material and economic context that is, on a broad scale, structured around the power and interests of a "ruling class" (consisting of those who occupy the dominant positions in a society's dominant mode of production).

Thus, on the societal level too, consciousness and ideas are secondary to the configuration of production relations, the resultant distribution of resources, and institutional structures in general. Ideologies will tend to predominate that either legitimate or are compatible with the interests of those people who have the most control over the most resources, i.e., the ruling class. As Marx said, "the ideas of the ruling class are in every epoch the ruling ideas." 231 True understanding of social dynamics, therefore, necessarily exists on a materialist foundation. ${ }^{232}$

Aside from these general considerations, the obvious reason why Marxism keeps reappearing in the broader culture is that Marx was basically right in his analysis of capitalism: the economy is prone to crisis, class polarization has a pronounced tendency to increase (unless held in check by other forces), the working class tends to be relatively or absolutely immiserated, people in general are commodified and dehumanized in capitalist society, commodities are

\footnotetext{
${ }^{231}$ Needless to say, this pat formula is of less use with regard to eras in which two or more classes are contending for supremacy, such as during the eighteenth century in Western Europe.

${ }^{232}$ For a study that shows the power of such a materialist analysis, see Thomas Ferguson and Joel Rogers, Right Turn: The Decline of the Democrats and the Future of American Politics (New York: Hill and Wang, 1986). Charles Beard, An Economic Interpretation of the Constitution of the United States (New York: The Macmillan Company, 1913) is a stillcompelling classic. The political writings and interview collections of Noam Chomsky (Understanding Power is an easy-to-read example) likewise demonstrate the persuasiveness, indeed the commonsensicalness, of materialism.
} 
"fetishized," and so forth. In fact, all it takes is an unbiased mind to see that Marxian perspectives on all facets of capitalism are extraordinarily penetrating: the writings of E. P. Thompson, Raymond Williams, Paul Sweezy, Ernest Mandel, Harry Braverman, David Montgomery, Gabriel Kolko, Robert Brenner, Erik Olin Wright, Göran Therborn, Thomas Ferguson, David Harvey, John Bellamy Foster, and numerous other academic Marxists of the last sixty years are sufficient to prove this. And of course there are the writings of Marx and Engels themselves to consider, as well as of the second generation of Marxists (roughly Lenin's generation). In short, there is no question that Marxism is here to stay.

Given the unique power of this intellectual system, it is wholly justified to reconsider what is perhaps its weakest aspect, its theory of revolution. Marxists have traditionally been hostile to cooperatives as a tool of revolution, but as we'll see, a properly understood Marxism is in fact strategically committed to cooperatives. Even more importantly, a reconsideration and modification of Marx's theory of revolution will enable us to understand how a transition to socialism, or something like it, can happen, and what role cooperatives and other "alternative economy" institutions will play in that transition.

These are big topics, and the discussion in this chapter will necessarily be both wide-ranging and schematic. There isn't space to go into the detail I'd like. Still, lest the reader lose the thread of the argument in the thicket of ideas, I'll outline it here. The main point that ties it all together is that I reject Marx's statism, and I do so for reasons that I think are more faithful to Marxism than his own statist conception of the "dictatorship of the proletariat" is. I find it astonishing, in fact, that, as far as I know, no one has ever appreciated the radically un-Marxian character of that conception, the fact that it doesn't follow logically from the basic premises of Marxism. Quite the contrary: as I'll argue in chapter six-though it is also implicit in this chapter - the spirit of anarcho-syndicalism is much closer to the essence of Marx's thought than Leninism and statism are. This isn't just an academic debate, by the way. For one thing, Marxists should know what they are logically committed to, 
and in what respects Marx got his own ideas wrong. It's also important to cleanse and update the theoretical system in order to keep it a living force, to salvage its insights and put them to use in our own urgent struggles. It seems to me that intellectual integrity is a virtue, and ideas can have powerful practical repercussions.

My rejection of Marx's statism, i.e., his adherence (despite his internationalism) to the framework of the nation-state, leads to my argument that only in the twenty-first century are we finally entering the revolutionary period Marx and Engels looked forward to. That is, they got the timeline wrong: international socialist revolution never could have happened in the nineteenth or twentieth centuries, for reasons I explain later. Their impatience got the best of them. Only now is the nation-state system beginning to deteriorate-and global revolution never could have happened before this deterioration started. In part to explain why this is the case, and what it is about our contemporary world that makes it so much more pregnant with international revolutionary potential than the world of, say, eighty or a hundred years ago was, I briefly review the "historical logic" of the evolution of capitalism and the nation-state into the neoliberal present. On the most abstract level, one can view the last 150 years or so in the West as consisting of, first, a relatively "pure" and "unregulated" capitalism that, through the conflicts it engendered between labor and capital (and the resultant economic crises of "underconsumption" and "overproduction"), necessitated the birth of the regulated Keynesian welfare state, in the heyday of the nationstate era between the 1930s and 1960s. This period was the interregnum, so to speak, between the first era of semi-"pure" capitalism and the second, which began in the 1980s and has continued to the present. As before, the relative lack of government economic regulation and the disempowerment of organized labor are leading to extreme social discontent and economic crisis/stagnation. This time, however, the old nationalist Keynesian "compromise" is not a possible solution, because the nation-state system is succumbing to the disintegrating effects of transnational capital.

So, the current decline of the nation is the world-historic development that, together with the emerging period of global 
economic stagnation, will make possible a (very protracted) social revolution-centered not around national states but around grassroots movements, municipal democratic experiments, regional networking, and transnational coordination of anti-capitalist resistance. It was always inevitable that this was how the revolution would happen, as opposed to un-Marxist fantasies of "the working class" taking over national states and directing economic reconstruction from above. Such a proletarian dictatorship has never happened and never can happen, as follows from the premises of Marxism itself.

After setting out this theoretical framework, I consider its implications in practice. My focus this time isn't on worker cooperatives, since I discuss those in other chapters, but on things like municipal enterprise and participatory budgeting. I argue that these are the seeds of the new economy, the post-capitalist society that will germinate in the next century or two. After reviewing a few of these initiatives, I conclude the chapter by considering why states and ruling classes will allow-indeed, are allowing-the "revolution" to happen despite its anti-capitalist character. At certain points in the discussion I try to draw parallels with the earlier transition in Western Europe from feudalism to capitalism. I think that if we examine that earlier revolution carefully, we'll find clues as to how the future will unfold.

This chapter is necessarily dense; it could itself be expanded into a book or two. Its main purpose, again, is just to sketch a framework by which we can interpret the recent and future growth of alternative economic arrangements in the interstices of a decaying civilization. I'll leave it to a future book to fill in the details.

\section{Theory}

Marx has, in effect, two theories of revolution, one that applies only to the transition from capitalism to socialism and another that is more transhistorical, applying, for instance, also to the earlier transition between feudalism and capitalism. I will consider, and revise, each of these in turn. Both see the working class as the agent 
of transition to a post-capitalist economy. Whatever Marx meant by "working class," in the following discussion I will interpret the term broadly, as denoting the majority of wage-earners - except those whose high income, high managerial positions, ownership of stocks, and so on effectively align them with the capitalist rather than the working class. It has long been known that many people in modern society, especially those in the "middle class," have contradictory class locations, sharing some interests with capitalists and others with low-wage workers. This is what makes it possible for the middle class sometimes to act in radical ways and other times in reactionary ways. ${ }^{233}$ Typically, in fact, the middle class has been the conservative bastion of social order; nevertheless, the wage-earning status of most of its members always holds out the possibility that someday they will act in radical opposition to those who own capital. If they lose their middle-class status, whether through economic crisis or some other cause, this possibility becomes more likely.

Among the people who will or can serve as the agents of transition to a new society are, for example, industrial workers, clerical workers, low-wage service workers, a majority of teachers, the unemployed, and in general those people who are relatively disempowered by corporate capitalism or have grievances that can be remedied by a dismantling of capitalism. This category of people in fact also includes others whom Marx would probably not consider working-class: most students, peasants, dispossessed indigenous peoples, even environmental activists (for such activism is really part of the class struggle, the struggle against the predatory capitalist class). All these people and more, the totality of whom amounts to the large majority of humanity, have interests opposed to the profitmaking, environmentally destructive, humanly exploitative,

${ }^{233}$ See, e.g., Robert Johnston, The Radical Middle Class: Populist Democracy and the Question of Capitalism in Progressive-era Portland, Oregon (Princeton: Princeton University Press, 2003); Christopher Lasch, The True and Only Heaven: Progress and Its Critics (New York: Norton, 1991); and Lewis Corey, The Crisis of the Middle Class (New York: Covici Friede, 1935). 
universally commodifying, undemocratic imperatives of corporate capital, and therefore are effectively the "workers of the world" whom Marx called to "unite." This is how we should interpret his call in the twenty-first century.

Let's consider, then, the basics of his theory of how capitalism will gave way to socialism. The pivot of the theory is capital's unquenchable thirst for profit, for surplus-value. It seeks always to squeeze more surplus-value out of the worker, which is to say value for which the worker does not receive an equivalent in wages. ${ }^{234}$ This entails the reduction of wages to as low a level as possible (given societal conditions, workers' power, the skill-level of the job, etc.) and the intensification of work to as high a level as possible. Capital invests its earnings in labor-saving, money-saving schemes like mechanization, ever-increasing mechanization so as to employ fewer workers, especially fewer skilled ones, control them more effectively, and generate more profit. At the same time, it expands its operations and puts less profitable competitors out of business. These failed competitors - who historically have included artisans, craftsmen, much of the petty-bourgeoisie, and many capitalists themselves - are forced to become wage-earners as the relatively few surviving capitalists acquire more money and power. Most of the peasantry, too, is eventually forced off the land through myriad pressures of "push" and "pull," swelling the ranks of the working class. The "reserve army of the unemployed" also tends to grow, in part because periodic economic crises throw people out of work and

\footnotetext{
${ }^{234}$ This controversial theory of surplus-value is really nothing but common sense, like most of Marxism. If a worker's wages were equivalent to all the value he produces in the form of a product that goes on the market, the capitalist couldn't make any profit. He obtains a surplus value over and above what he pays for workers and equipment. On Marxian economics, see, among innumerable others, Ernest Mandel, Marxist Economic Theory (London: The Merlin Press, 1968); Paul Sweezy, The Theory of Capitalist Development: Principles of Marxian Political Economy (New York: Monthly Review Press, 1942); and David Harvey, The Limits to Capital (Chicago: University of Chicago Press, 1982).
} 
shutter unprofitable businesses. Without delving into Marxian economics, we can say that these are typically crises of overproduction and/or underconsumption, the latter a product of the endemic drive to lower wages and employ as few workers as possible. That is to say, low effective demand leads to disincentives for business to invest and incentives to cut costs, which means laying off workers and paying them less, thus aggravating the macroeconomic problem. ${ }^{235}$ The end-result of all these tendencies, at least according to Marx's ideal model, is that the working class and the unemployed population become larger and poorer, while the capitalist class gets smaller (at least relatively) and wealthier. Society becomes increasingly divided into two polarized classes. Workers' self-interest and collective grievances impel them to fight together for their power and dignity: they form unions and other associations, some of them political, that train them in struggle and radicalize them. Because their demands can ultimately not be met in the framework of capitalism, at length they seek to take over the state so as to remake the economy along democratic, i.e. socialist, lines. Marx thinks that eventually they are destined to succeed, if only because of their overwhelming numbers and their decades of organizing themselves.

To repeat, this is an ideal model and therefore, like all models, a simplification. The question is how closely it resembles reality. The answer appears to be: in some respects very much so, in others not. In particular, the analysis of how capitalism works seems clearly to be an accurate, if idealized, model of definite tendencies in the real world. On the other hand, the prediction of radicalization of the masses - their increasing class-consciousness - and eventual overthrow of the bourgeois state seems not to have been fulfilled.

${ }^{235}$ See, e.g., David Harvey, The Enigma of Capital (New York: Oxford University Press, 2011) and Richard Du Boff, Accumulation and Power: An Economic History of the United States (New York: M. E. Sharpe, Inc., 1989). On the concept of overproduction, see Robert Brenner, The Economics of Global Turbulence (New York: Verso, 2006). He departs from orthodox Marxian economics, though. 
Before considering these matters in greater depth, however, I'll describe Marx's "second" theory of revolution, the transhistorical theory.

Its locus classicus is the last four sentences of the following paragraph from Marx's Preface to A Contribution to the Critique of Political Economy:

In the social production of their existence, men inevitably enter into definite relations, which are independent of their will, namely relations of production appropriate to a given stage in the development of their material forces of production. The totality of these relations of production constitutes the economic structure of society, the real foundation, on which arises a legal and political superstructure and to which correspond definite forms of social consciousness. The mode of production of material life conditions the general process of social, political and intellectual life. It is not the consciousness of men that determines their existence, but their social existence that determines their consciousness. At a certain stage of development, the material productive forces of society come into conflict with the existing relations of production orthis merely expresses the same thing in legal terms-with the property relations within the framework of which they have operated hitherto. From forms of development of the productive forces these relations turn into their fetters. Then begins an era of social revolution. The changes in the economic foundation lead sooner or later to the transformation of the whole immense superstructure.

There are several problems with this theory as expressed here. First of all, it is clearly the barest of outlines, desperately in need of elaboration. Unfortunately, nowhere in Marx's writings does he elaborate it in a rigorous way. Second, it is stated in functionalist terms. Revolution happens supposedly because the productive forces-i.e., technology, scientific knowledge, labor-power and labor 
skills, and technical methods of work organization-have advanced to such a point that production relations are no longer compatible with their socially efficient use and development. But what are the causal mechanisms that connect this functionalist concept of "fettering of the productive forces" to social revolution? As far as I know, nowhere does Marx express his theory in causal, as opposed to functionalist, terms.

Perhaps the biggest problem is that, as it's stated above, the theory borders on meaninglessness. How does one determine when production relations have started to impede the use and development of productive forces? It would seem that to some extent they are always doing so. In capitalism, for example, one could point to the following facts: (1) recurring recessions and depressions periodically make useless much of society's productive capacity; (2) enormous amounts of resources are wasted on socially useless advertising and marketing campaigns; (3) there is a lack of incentives for capital to invest in public goods like mass transit, the provision of free education, and public parks; (4) the recent financialization of the Western economy has entailed investment not in the improvement of infrastructure but in glorified gambling that doesn't benefit society; (5) artificial obstacles such as intellectual copyright laws hinder the development and diffusion of knowledge and technology; (6) a colossal level of expenditures is devoted to war and destructive military technology; (7) in general, capitalism distributes resources in a profoundly irrational way, such that, for example, hundreds of millions of people starve while a few become multi-billionaires. Despite all this, however, no revolution has happened.

Indeed, in other respects capitalism continues to develop productive forces in a striking way, as shown by recent momentous advances in information technology. It's true that - contrary to the fantasies of "free market" fanatics - this technology was originally developed in the state sector; nevertheless, the broader economic and social context was and is that of capitalism. It is therefore clear that a mode of production can "fetter" and "develop" productive forces at the same time, a fact Marx didn't acknowledge. 
In order to salvage his hypothesis quoted above, and in fact to make it quite useful, a subtle revision is necessary. We have to replace his idea of a conflict between productive forces and production relations with that of a conflict between two sets of production relations, one of which uses productive forces in a more rational and "un-fettering" way than the other. This change, slight as it might seem, has major consequences for the Marxist theory of revolution. It is no exaggeration to say that, in addition to making the theory logically and empirically cogent, it changes its entire orientation, from advocating a "dictatorship of the proletariat" that directs social and economic reconstruction to advocating a more grassroots-centered long-term evolution of social movements that remake the economy and society from the ground up. I will also argue that my revision makes the theory more compatible with the basic premises of Marxism itself, and that a statist version of Marxism, such as Leninism, is both un-Marxist and unrealistic.

My revision to the theory, then, is simply that at certain moments in history, new forces and relations of production evolve in an older economic and social framework, undermining it from within. For different reasons in different cases, the new production relations spread throughout the society, gradually overturning the traditional economic, social, political, and cultural relations, until a more or less new society has evolved. This happened, for example, with the Neolithic Revolution (or Agricultural Revolution), which started around 12,000 years ago. As knowledge and techniques of agriculture developed that made possible sedentary populations, the hunter-gatherer mode of production withered away, as did the ways of life appropriate to it.

Likewise, starting around the twelfth and thirteenth centuries in parts of Europe, an economy and society organized around manorialism and feudalism began to succumb to an economy centered around the accumulation of capital. Several factors contributed to this process, among them (1) the revival of longdistance trade (after centuries of Europe's relative isolation from the rest of the world), which stimulated the growth of merchant capitalism in the urban interstices of the feudal order; (2) mercantile 
support for the growth of the nation-state with a strong central authority that could dismantle feudal restrictions to trade and integrated markets; (3) the rise, particularly in England, of a class of agrarian capitalists who took advantage of new national and international markets (e.g., for wool) by investing in improved cultivation methods and enclosing formerly communal lands to use them for pasturage; (4) the partly resultant migration of masses of the peasantry to cities, where, during the centuries from the sixteenth to the nineteenth, they added greatly to the class of laborers who could be used in manufacturing; (5) the discovery of the Americas, which further stimulated commerce and the accumulation of wealth. In short, from the thirteenth to the nineteenth centuries, capitalist classes - agrarian, mercantile, financial, and industrial-emerged in Europe, aided by technological innovations such as the printing press and then, later on, by all the technologies that were made possible by the Scientific Revolution of the seventeenth century. All this is just to say that in the womb of the old society, new productive forces and production relations evolved that were more dynamic and wealthgenerating than earlier ones. Moreover, on the foundation of these new technologies, economic relations, and scientific discourses arose new social, political, and cultural relations and ideologies that were propagated by the most dynamic groups with the most resources, i.e., the bourgeoisie and its intellectual hangers-on. ${ }^{236}$

It's true that numerous political clashes had to occur before the rising bourgeoisie could achieve hegemony over Europe. Both the

\footnotetext{
${ }^{236}$ Among many others, see Phyllis Deane, The First Industrial Revolution (New York: Cambridge University Press, 1979); Robert Brenner, "The Origins of Capitalist Development: A Critique of Neo-Smithian Marxism," New Left Review I/104, July-August 1977, 25-92; Rodney Hilton, ed., The Transition from Feudalism to Capitalism (London: New Left Books, 1976); T. S. Ashton, The Industrial Revolution, 1760-1830 (Westport, CT: Greenwood Press, 1986); Giovanni Arrighi, The Long Twentieth Century: Money, Power, and the Origins of Our Times (New York: Verso, 1994); and Robert Allen, The British Industrial Revolution in Global Perspective (New York: Cambridge University Press, 2009).
} 
feudal aristocracy and absolutist monarchies opposed the bourgeois doctrines of economic and political liberalism, such that a series of revolutions was necessary before the bourgeoisie could accede to political power. The point relevant to the following discussion is that once capitalist economic relations had reached a relatively mature and widespread level, the ultimate political victories of the capitalist class were inevitable, if only because of this class's continuing growth and access to more resources than its opponents had. Furthermore, it was only when capitalist economic relations had already made significant progress that bourgeois political revolutions were possible.

We should apply the lessons of the transition from feudalism to capitalism to the future transition from capitalism to some other system. This, too, will have to happen in a very gradual way, as new production relations sprout in the "interstices" of a decaying order. Briefly stated, one can expect that capitalism's descent into longterm crisis (or stagnation) will generate - or rather, is generatingmovements of resistance across the world, many of which will be devoted to establishing new cooperative modes of production and distribution that will assist millions of the unemployed and the castoff in their tasks of survival. Explicitly political anti-capitalist resistance will spread too, but it cannot possibly attain the summits of political power without having command over tremendous resources, sufficient resources to compete against the ruling class. An important way of acquiring such resources is by accumulating capital through business activities, such as cooperatives and other "alternative economy" institutions do. Thus, just as the bourgeoisie could not achieve power before the capitalist economy had conquered much of Europe, so the working class cannot take over political power (on a broad scale) before its own economic institutions, its "socialist" institutions, have partially remade the world economy. Sooner or later, durable alliances will have to be made between the alternative economy and political movements if the latter are to succeed in their ultimate objectives. On a global level this process can be expected to take at least a century or two. 
Before examining these ideas in more detail, it's worth reviewing the advantages of the revision I've made to Marx's theory of revolution. Again, my argument is just that social revolution happens when an old set of production relations fetters-or irrationally uses - productive forces in relation to a new set of widely emerging production relations. The "in relation to..." that I have added saves the theory from meaninglessness, for it indicates a definite point at which the "old" society really begins to yield to the "new" one, namely when an emergent economy has evolved to the point that it commands substantial resources and is clearly more "rational" in some sense than the old economy. Whether this hypothesis applies to all social revolutions is a question I won't consider here; the point is that it does apply to some, and it will surely apply to any transition between capitalism and cooperativism. (See below.)

Another advantage of my revision is that it supplies a causal mechanism by which a particular mode of production's "fettering of the productive forces" leads to revolution-indeed, to successful revolution. The mechanism is that the emergent mode of production, in being less dysfunctional and/or more "efficient" than the dominant mode, eventually (after reaching a certain visibility in the society) attracts vast numbers of adherents who participate in it and propagandize for it - especially if the social context is one of general economic stagnation and class polarization, due to the dominant mode of production's dysfunctionality. Moreover, this latter fact means that, after a long evolution, the emergent economic relations and their institutional partisans will have access to so many resources that they will be able to triumph economically and politically over the reactionary partisans of the old, deteriorating economy. Again, this is what ultimately ensured the political success of the bourgeoisie in its confrontations with the feudal aristocracy. Similarly, if capitalism continues to stagnate and experience manifold crises, this will ensure the global victory of a cooperative mode of production that will have developed over generations in the interstices of capitalist society. 
So, in short, my revision provides a necessary condition for the success of an anti-capitalist revolution, and thus, as we'll see in a moment, helps explain why no anti-capitalist revolution so far has been successful in the long term (namely because the condition has been absent). Another way of seeing the implications and advantages of the revision is by contrasting it with the views of orthodox Marxists. A single sentence from Friedrich Engels sums up these views: "The proletariat seizes state power, and then transforms the means of production into state property." 237 This statement, approved by Lenin and apparently also by Marx, encapsulates the mistaken statist perspective of the orthodox Marxist conception of proletarian revolution. This perspective is briefly described in the Communist Manifesto, where Marx writes "The proletariat will use its political supremacy to wrest, by degree, all capital from the bourgeoisie, to centralise all instruments of production in the hands of the State, i.e., of the proletariat organised as the ruling class," and then lays out a ten-point plan of social reconstruction by means of state decrees. By the 1870s Marx had abandoned the specifics of his earlier plan, but his (qualified) statism remained, and transmitted itself to his followers. ${ }^{238}$ It's true that orthodox Marxists expect the state, "as a state," to somehow wither away eventually, but they do have a statist point of view in relation to the early stages of revolution.

This statist vision emerges naturally from both of Marx's theories of revolution discussed above: from the first one, because Marx simply assumes that the main task of the working class has to be to take over the national state (i.e., all national states), and that in the long run its efforts will be devoted to this task; from the second,

${ }^{237}$ Quoted in Lenin, State and Revolution (New York: International Publishers, 1969), 15.

${ }^{238}$ See, e.g., ibid., 51, 52. Marx's pamphlet The Civil War in France, written in 1871, expresses an attitude close to anarchism, but it's not clear that this essay is a direct statement of his considered views. To a great extent it had to be a eulogy for the Commune and a defense of it against its bourgeois critics, not just a neutral discussion of what it did right and wrong. Elsewhere, Marx is critical of the Commune. 
because the idea of a conflict between the rational use and development of productive forces and the fettering nature of current production relations suggests that at some point a social "explosion" will occur whereby the productive forces are finally liberated from the chains of the irrational mode of production. Pressure builds up, so to speak, over many years, as the mode of production keeps fettering the socially rational use of technology and scientific knowledge; through the agency of the working class, the productive forces struggle against the shackles of economic relations; at length they burst free, when the working class takes over the state and reorganizes the economy. These are the metaphors naturally conjured by the paragraph quoted above from the Preface to $A$ Contribution to the Critique of Political Economy.

But there are logical and empirical problems with the statist view, the view according to which the substance of social revolution occurs after the seizure of state power. First of all, it is in tension with the Marxian conception of social dynamics. Briefly stated, Marx sees the economy - rightly, I think - as the relative foundation of the rest of society, including politics, which suggests that a postcapitalist social revolution cannot be politically willed and imposed. This would seem to reverse the order of "dominant causality," from politics to the economy rather than vice versa. Moreover, such extreme statism exalts will as determining human affairs, a notion that is quite incompatible with the dialectical spirit of Marxism. History really happens "behind the backs" of actors: it evolves "unconsciously," so to speak, as Hegel understood. Social and institutional conflicts work themselves out, slowly, through the actions of large numbers of people who generally have little idea of the true historical significance of their acts. As Marx said, we should rarely put credence in the self-interpretations of historical actors (because they are constrained and influenced by objective institutional realities of which they're little aware or which they 
interpret incorrectly). ${ }^{239}$ And yet apparently he suspends this injunction, and his whole dialectical method, when it comes to the so-called proletarian revolution. These historical actors are somehow supposed to have perfect understanding of themselves and their place in history, and their historical designs are supposed to work out perfectly and straightforwardly-despite the massive complexity and "dialectical contradictions" of society.

The reality is that if "the working class" or its ostensible representatives seize control of the state in a predominantly capitalist society-and if, miraculously, they aren't crushed by the forces of reaction - they can expect to face overwhelming obstacles to the realization of their revolutionary plans. Some of these obstacles are straightforward: for example, divisions among the new ruling elite, divisions within the working class itself (which is not a unitary entity), popular resistance to plans to remake the economy, the necessity for brutal authoritarian methods of rule in order to force people to accept the new government's plans, the inevitable creation of a large bureaucracy to carry out so-called reconstruction, etc. Fundamental to all these obstacles is the fact that the revolutionaries have to contend with the institutional legacies of capitalism: relations of coercion and domination condition everything the government does, and there is no way to break free of them. They cannot be magically transcended through political will. In particular, it is impossible through top-down directives to transform production relations from authoritarian to democratic; Marxism itself suggests that the state is not socially creative in this way. The hope to reorganize exploitative relations of production into liberatory, democratic relations by means of bureaucracy and the exercise of a unitary political will-the "proletarian dictatorship"-is utterly utopian and un-Marxist.

${ }^{239}$ On the importance of objective institutional contexts to, e.g., the course of mass movements, see Frances Fox Piven and Richard A. Cloward, Poor People's Movements: Why They Succeed, How They Fail (New York: Vintage Books, 1979). 
The record of so-called Communist revolutions in the twentieth century is instructive. While one can expect some Marxists to deny that lessons should be drawn from these revolutions, since they happened in relatively primitive rather than advanced capitalist countries, the experiences are at least suggestive. For what they created in their respective societies was not socialism (workers' democratic control of production) or communism (a classless, stateless, moneyless society of anarchistic democracy) but a kind of ultra-statist state capitalism. To quote Richard Wolff, "the internal organization of the vast majority of industrial enterprises [in Communist countries] remained capitalist. The productive workers continued in all cases to produce surpluses: they added more in value by their labor than what they received in return for that labor. Their surpluses were in all cases appropriated and distributed by others." ${ }^{240}$ Workers continued to be viciously exploited and oppressed, as in capitalism; the accumulation of capital continued to be the overriding systemic imperative, to which human needs were subordinated. While there are specific historical reasons for the way these economies developed, the general underlying condition was that it was and is impossible to transcend the capitalist framework if the political revolution takes place in a capitalist world, ultimately because the economy dominates politics more than political will can dominate the economy.

In any case, it was and is breathtakingly utopian to think that an attempted seizing of the state in an advanced and still overwhelmingly capitalist country, however crisis-ridden its economy, could ever succeed, because the ruling class has a virtual monopoly over the most sophisticated and destructive means of violence available in the world. Even rebellions in relatively primitive countries have almost always been crushed, first because the ruling classes there had disproportionate access to means of violence, and second because the ruling classes in more advanced

${ }^{240}$ Richard Wolff, Democracy at Work: A Cure for Capitalism (Chicago: Haymarket Books, 2012), 109. 
countries could send their even more sophisticated instruments of warfare to these countries in order to put down the revolution. But if a massive rebellion happened in one of the core capitalist nations, as opposed to a peripheral one, the reaction of ruling classes worldwide would be nearly apocalyptic. They would prefer the nuclear destruction of civilization to permitting the working class or some subsection of it to take over a central capitalist state.

My revision of Marx's theory of revolution avoids all these problems while still retaining key insights about the inevitable causes of revolution. It's obvious that any transition to a new society, if carried out largely through the agency of the oppressed masses (which it will have to be), will be a consequence of capitalism's socially irrational distribution of resources and fettering of the productive and democratic potential of current "forces of production." If used sensibly, there is no question that modern wealth, technology, and scientific know-how could make possible adequate shelter, sustenance, and security for billions more people than currently enjoy them. An anti-capitalist revolution will be motivated by the imperative to redress these (and other) inequalities and injustices, and it will necessarily take the form of instituting new, more democratic property and production relations. Whether such a revolution is "inevitable," as Marx and Engels seem to have believed, is a question I will consider later. I will also consider the reasons why the state and the ruling class will allow a revolution of the "gradual" sort I have described to happen. The point is that the only possible way - and the only Marxist way - for a transition out of capitalism to occur is that it be grounded in, and organized on the basis of, the new, gradually and widely emerging production relations themselves. This is the condition that has been absent in all attempts at revolution so far, and it explains why, aside from a few isolated pockets of momentary socialism (such as Catalonia in 1936), they never managed to transcend a kind of state capitalism. They existed in a capitalist world, so they were constrained by the institutional limits of that world.

Ironically, Marx understood that this would be the case unless the revolution was international. He understood that "socialism in 
one country" is impossible. He knew that unless a rebellion in Russia triggered or coincided with rebellions elsewhere, which on an international scale worked together, so to speak, to build a socialist mode of production, it was doomed to failure. What he didn't understand was that the only way a revolution can be international is that it happen in a similar way to the centuries-long "bourgeois revolution" in Europe and North America, namely by sprouting first on the local level, the municipal level, the regional level, and expanding on that "grassroots" basis. The hope that the states and ruling classes of many nations can fall at approximately the same time to a succession of national uprisings of workers - which is the only way that Marx's conception of revolution can come to pass-is wildly unrealistic, again because of the nature of capitalist power dynamics that Marxism itself clarifies.

Indeed, only recently has capitalism attained the truly globalized condition that Marx assumed was a necessary prerequisite for revolution. While there are good reasons to say that the USSR and Communist China before the 1980s or 1990s were in some respects state capitalist, their "capitalism" was very different from the competitive, market-driven system that is impelled by economic logic to expand and spread its dominion over the planet. This capitalism, which Wolff calls "private [as opposed to state] capitalism," has only in the last thirty-five years spread to huge areas of the world that had for a long time managed to hold it at bay. In addition to China, the USSR, and Eastern Europe, much of Latin America and Africa until the 1990s remained outside the domain of classical capitalist relations of production, defined by the presence of a mass of people who own nothing but their labor-power and are consequently forced to seek employment with those who own the means of production. The absence of these production relations was the result of many factors, for instance popular and elite reactions (such as, in some respects, the Mexican Revolution of 1910-1920 and its aftermath) against the predatory liberal capitalism and 
imperialism of the late nineteenth and early twentieth centuries. ${ }^{241}$ In other cases, such as parts of Central America, it was the result of international capitalism's shoring up domestic semi-serfdom, by means of the peculiar incentive structures created by "merchant capitalism" and the international division of labor (whereby some countries export raw materials, others export finished products). ${ }^{242}$ Finally by the 1980 s and 1990 s, all this semi-capitalism, semifeudalism, peasant resistance to proletarianization, state ownership of industries, and so on gave way to neoliberal offensives of privatization and marketization, such that the capitalist mode of production and its corresponding property relations have by now virtually conquered the world and are creating a truly global "proletariat" (or "precariat"). ${ }^{243}$ As they do so, resistance spreads and intensifies.

In order to understand what is likely to happen in the next fifty or a hundred years, it's useful to contextualize the historical moment we're living in. And to properly understand its context, it helps to resurrect an old, currently unfashionable idea, viz., that there is a kind of logic to history. That is, we should return to Marx's Hegelian notion that history, on the broadest scale, unfolds according to a certain "necessity," which is always evident in retrospect. This idea is commonly rejected nowadays, even by some Marxists, for two main reasons: first, it seems to deny that individuals have the power to shape history, that they are active agents in the historical process, instead treating them as mere tools of an impersonal historical "Reason"; second, it seems to valorize this Reason as being

${ }^{241}$ See Alan Knight, "The Mexican Revolution: Bourgeois? Nationalist? Or just a 'Great Rebellion?"' Bulletin of Latin American Research 4 (1985): 137; Friedrich Katz, The Secret War in Mexico: Europe, the United States, and the Mexican Revolution (Chicago: University of Chicago Press, 1981); and Leslie Bethell, ed., Mexico Since Independence (Cambridge: Cambridge University Press, 1991).

${ }^{242}$ Robert Brenner, "The Origins of Capitalist Development."

243 "Guy Standing: 'Precariat' of Insecure Workers Is Stirring," The Cap Times, November 6, 2011. 
synonymous with "Progress" in some quasi-moral sense, implying (supposedly) that, e.g., the rise of Europe in modern times was both inevitable and good, and that people - artisans, workers, peasantswho resisted such things as industrial capitalism were benighted and backward, the enemies of progress. The result of these misinterpretations is that few writers now are interested in excavating the structural tendencies, the dialectical self-undermining, the logic of "the emergence of the new within the shell of the old" by which historical phases have yielded to their successors. Radical authors like Richard Wolff, David Schweickart, and Michael Albert have largely abandoned Marx's quasi-"scientific" conception of socialism, according to which socialism not only should but will happen (by means of class struggle); their approaches to the subject are not so much historical as ethical. We should resurrect Marx's historical approach — which follows Hegel's in seeing the "truth," the "meaning," of the past as revealed by the present and future-in the process correcting his mistakes. ${ }^{244}$

Consider Marx's predictions that the impoverished working class would continue to expand until it constituted the majority of society, and that as it did so its class consciousness and radicalism would mature - internationally - to the point that world revolution would occur. In retrospect, we can see that he was wrong; he misunderstood

\footnotetext{
${ }^{244}$ In this unacademic book it wouldn't be appropriate to go into dense detail on these points, but they're fairly intuitive anyway. Institutional contexts determine that certain developments are possible, others impossible, and others highly probable or even inevitable. For example, anyone who has studied European history between the 1880s and 1910s knows that a cataclysmic war was, sooner or later, inevitable or nearly so; in 1887 Friedrich Engels even predicted it, with astonishing accuracy (all the way up to the number of soldiers killed: "eight to ten million" he said, when it turned out to be 9.7 million. See James Joll and Gordon Martel, The Origins of the First World War (New York: Routledge, 2013), 264). In short, with hindsight, one gets a broader perspective on evolving institutional dynamics, as the present and future emerge organically from the past.
} 
capitalist society. While there are indeed tendencies toward class polarization, impoverishment of workers, international class solidarity, and economic crisis, there are also tendencies toward assimilation of the working class into the dominant order, toward "pure and simple trade-unionism," toward the state's stabilizing management of the economy, and toward workers' identification not only with the abstract notion of a social class that spans continents but also with the more concrete facts of ethnicity, race, trade, immediate community, and nation. These identifications make possible the working class's fragmentation, which diminishes the likelihood of socialist revolution in the classical sense. Similarly, the historical successes of trade unionism obviated the necessity (from the proletariat's perspective) of revolution; reform was sufficient, at least in the short run, to improve the life situations of a large proportion of workers. Thus was born twentieth-century social democracy, the welfare state, and collective bargaining.

Marx was right that the capitalist class is averse to progressive initiatives like these, and that it has inordinate influence over the state; what he didn't appreciate was the historic potential of divisions within the class. The research of Thomas Ferguson, for example, has shown that the "second New Deal" (in 1935) in the United States, which led to the welfare state and federal protection of collective bargaining, was made possible by divisions in capitalist ranks between labor-intensive, domestically oriented, protectionist businesses, such as those in the textile industry, and capitalintensive, internationally oriented businesses, such as Standard Oil and General Electric. The former were viciously opposed to laborempowering measures like the 1935 Wagner Act, while the latter, who valued social stability more than savage repression of workers, in fact helped write the Wagner and Social Security Acts. ${ }^{245}$ Their support for Franklin Delano Roosevelt and the New Deal order made the U.S. welfare state possible (as did, in another sense, the struggles

245 Thomas Ferguson, Golden Rule: The Investment Theory of Party Competition and the Logic of Money-Driven Political Systems (Chicago: University of Chicago Press, 1995). 
of millions of workers). The welfare state-and the institutionalization of collective bargaining - in turn contributed to postwar economic and political stability, which for a while seemed to invalidate Marx's pessimistic analysis of capitalism. Trade unions became part of the "establishment"; much of the white working class became increasingly conservative, alienated from movements for radical social change, and intellectuals decided that Marx had been totally wrong all along.

In reality, though, what he was wrong about was the timeline, as I said earlier. It was impossible for capitalism to succumb to socialism in the nineteenth or twentieth centuries. Suppose, for instance, that by some unimaginable miracle Friedrich Engels' eager prophecies (in the 1880s) with regard to the Knights of Labor had been borne out. Aware of its experiments in cooperativism, its attempts at industrial unionism, and its radical rhetoric, Engels predicted that it would serve as midwife of a revolutionary class consciousness and class organization that would lead the workers to victory over capitalism. This couldn't have happened, of course, for obvious reasons. (The ruling class had a monopoly over the means of violence; divisions in the laboring classes, between black and white, skilled and unskilled, Catholic and Protestant, precluded the necessary continent-wide unity; most leaders of the labor movement were basically conservative, as they almost always have been.) But suppose capitalism had been overthrown in the United States in the late $1880 \mathrm{~s}$ or $1890 \mathrm{~s}$ and a semi-cooperative "republic of labor" had been founded, with artisans in their small workshops connected through cooperative networks, public control of industry, Rochdaletype consumer cooperatives proliferating around the nation. What would have happened then? Capitalists in Europe would have continued amassing profit, investing in mechanization, building up industry and technology, and the artisans, craftsmen, and selfgoverning industrial workers in the U.S. would have been, in the long run, unable to compete with them. In the end, the U.S.'s protosocialism would have eroded due to competition from Europe, and a degeneration to capitalism would have taken place, much as it did later in the Soviet Union. What this would have proven is that 
America's proto-socialist adventure, like the USSR's so-called "state socialism," was a historical detour, a dead end, a kind of accident. ${ }^{246}$

Economic conditions - and productive forces-simply were not "ripe" then, or in the twentieth century, for socialism. It certainly is appalling to contemplate the irony of this fact. It's an absurd, senseless tragedy: millions of people in the Americas, in Russia and Asia, in Germany, in France, in Spain and Italy spending decades fighting and dying for a dream that would never have come to fruition anyway because, supposing they had achieved something like it in a particular region, such as Catalonia, and it had not been crushed by the forces of reaction, it would have slowly degenerated under market pressures from the broader capitalist society, pressures on wages-downward for the lower workers, upward for the higher-pressures to mechanize, and the business cycles that inevitably would have seeped in to these havens of cooperation and disturbed the order of things, and of course after the revolutionary fervor had subsided the usual daily problems of running factories would have cropped up, "alienation" would have returned because industrial work is inherently unpleasant, battles between management and the average worker would have spoiled the revolution. Mondragon's recent evolution confirms these counterfactual claims. So, the irony is shockingly cruel: it is when capitalist industrialization was starting, precisely when socialism was least possible, that workers, artisans, peasants, and intellectuals fought with greatest heroism and determination for socialism. Industrialization was so brutal and so conducive to the lower classes' radicalization that visions of, and struggles for, a cooperative society were inevitable everywhere. But they didn't have the significance their participants thought they did. They were, so to speak, symptoms of the birth-pangs of industrial capitalism, not of its deaththroes. Or, to view the matter from a different perspective, they were-in the long run-symptoms of the (conflict-ridden) maturation and consolidation of the nation-state, not of the imminent

${ }^{246}$ On Leninism and the Soviet Union, see chapter six. 
overcoming of capitalism. A global system structured around statecapitalist nation-states was always the inevitable outcome, despite the utopian hopes of millions of oppressed people.

This, indeed, is another way of expressing Marx's mistake: political conditions were not ripe for international socialist revolution. Marx didn't foresee the "mature nation-state" period of history, which is to say the twentieth century. He profoundly underestimated the power of the "nationality" principle, and of the state. In many ways he was right that the class principle is more important than the nation principle, but not in the way he wanted: business tended to be more loyal to class than to the nation, and it used the idea of nationality to divide the working class and maintain social control. (For example, big business subsidized and continues to subsidize fascist or semi-fascist movements because they distract from the class struggle and serve business's political agendas; and its frequent support for "patriotic" wars is a function not only of their profit-making potential but also of their usefulness in stifling domestic social discontent and progressive political movements. ${ }^{247}$ ) For other reasons too, though, the nation-state's central authority was bound to get stronger, more bureaucratic, more extensive, more "society-regulating," more effective at manufacturing consent, than it was in, say, the 1870s. In retrospect we can see this. From the Middle Ages on, capitalism and the nation-state have grown up together in a symbiotic relationship (at least until very recently); it was inevitable that as capitalism continued to grow in power and extent in the early and middle twentieth century, the nation-state would do so as well. ${ }^{248}$

There isn't space here to discuss all the reasons for the necessary failure of Marx's prophecies in the historical short term, or for the

${ }^{247}$ See J. A. Hobson, Imperialism: A Study (New York: J. Pott \& Co., 1902).

${ }^{248}$ See Peter Kropotkin, The State: Its Historic Role (London: Freedom Press, 1997), and Karl Polanyi, The Great Transformation: The Political and Economic Origins of Our Time (Boston: Beacon Press, 1971). 
inevitability of the "high modernist" period of the nation-state. ${ }^{249} \mathrm{I}$ could, for instance, draw from the Marxian tradition itself and argue that an era of "monopoly capital" necessarily followed the nineteenth-century era of competitive capitalism, and that monopoly capitalism necessarily engendered certain varieties of state capitalism, corporatism, fascism, state welfarism, etc. ${ }^{250}$ Instead I'll invoke Karl Polanyi's arguments in The Great Transformation, while adding my own perspective, which brings the story up to the neoliberalism of the present day. Permit me to quote from my Notes of an Underground Humanist:

It's always dangerous to construct abstract schemas, but there appear to have been two, or rather one-and-a-half, "cycles" in capitalist history. Abstractly you can think of it in this way: first, a lot of ancient [feudal] communal practices and public goods [such as the peasant commons] were dismantled before, during, and after the Industrial Revolution. You can call this the first wave of privatization. (It has continued unceasingly all over the world, but let's just call it the first wave.) As it was going on, the victims of capitalism sought to maintain their old rights and/or acquire new, governmentally protected ones. At length they succeeded to some extent, and new public goods were consolidated under the 20th-century Keynesian welfare state. This was probably a nearly inevitable development, because, as Karl Polanyi said in The Great Transformation,

\footnotetext{
${ }^{249}$ James C. Scott, Seeing Like a State: How Certain Schemes to Improve the Human Condition Have Failed (New Haven: Yale University Press, 1998).

${ }^{250}$ See Rudolph Hilferding, Finance Capital: A Study in the Latest Phase of Capitalist Development (London: Routledge \& Kegan Paul, 1981 (1910)); Paul Baran and Paul Sweezy, Monopoly Capital: An Essay on the American Economic and Social Order (New York: Monthly Review Press, 1966); and Robert A. Brady, Business as a System of Power (New York: Columbia University Press, 1943).
} 
marketization and privatization will, if unchecked, eventually cause the total destruction of society. So popular resistance, aided by sane elements of the upper classes, succeeded in regulating further depredations and temporarily saving society after the Great Depression. But technology kept progressing, capital mobility increased, global integration continued, populations kept growing, and the "public" and politicized nature of the Keynesian state started encroaching too much on capitalist class power. Finally the masses got out of hand, got too politicized, too powerfulall those crazy ideas of democracy in the 1960s! - and there was a capitalist backlash, made possible by (and making possible) ever-more-globally-integrated markets, elite institutional networks, and extreme capital mobility worldwide. The inflationary consequences of relative popular empowerment in a context of economic stagnation (the 1970s) were tamed, namely by destroying popular empowerment. That is, the second wave of privatization occurred, after the 1970s: public goods were again dismantled and "capital accumulation by dispossession" began anew (though, in truth, it had never really stopped). This time, the old nationalist Keynesian solution to the horrors of privatization wasn't available, since the world had become too integrated and nations themselves were deteriorating, due to the post-1970s capitalist onslaught. So transnational social movements were necessary... ${ }^{251}$

Or, even more schematically:

With respect to the very long run, Marx was always right that capitalism is not sustainable. There are many reasons for this, including the contradiction between a system that requires infinite growth and a natural environment that is

${ }^{251}$ Wright, Notes of an Underground Humanist, 196, 197. 
finite, but the reason most relevant to Marxism is that ultimately capital can never stop accumulating power at the expense of every other force in society. It is insatiable; its [competition-driven] lust for ever more profit and power condemns it to a life of Faustian discontent. It can never rest. Any accommodations, therefore, between the wage-earning class and capital - such accommodations as the welfare state and the legitimization of collective bargaining - are bound to be temporary. Sooner or later capital's aggressiveness will overpower contrary trends and consume everything, like a societal black hole (to change the metaphor). Everything is sucked into the vortex, including social welfare, the nationstate, even nature itself. The logic is that nothing will remain but The Corporation [in the plural], and government protections of the people will be dismantled because such protections are not in the interest of capital. This absurd, totalitarian logic can never reach its theoretical culmination, but it will, it must, proceed far enough, eventually, that an apocalyptic struggle between the masses and capital ensues. A relatively mild version of this happened once before, in the 1930s and '40s, and a compromise [in the West] - the mature welfare state- was the result. But then, as I said, capital repudiated the compromise (or is doing so as I write these words), and the old trends Marx diagnosed returned with a vengeance, and so humanity could look forward, this time, to a final reckoning. A final settling of accounts will occur in the coming century or two. ${ }^{252}$

Those two paragraphs sum up my argument as to the context in which the "new economy" of cooperatives and other anti-capitalist institutions is arising. The rise of neoliberalism (from the mid-1970s on) was inevitable, given the distribution of power in the West and the heightening of international economic competition after the

${ }^{252}$ Ibid., 173. 
1960 s. $^{253}$ In other words, a resurgence of global privatization and capitalist empowerment - after the consummation of the nation-state era between the 1930s and 1960s-was bound to happen, which means that social disintegration and atomization was bound to reach the pathological extremes of the present. This would inevitably, sooner or later, trigger massive resistance and creative efforts to reconstruct civil society and the economy on a new basis. These efforts are still in their infancy.

To elaborate in a little more detail: As David Harvey and others have argued, the corporate capitalist class in the U.S. and Britain faced two major problems in the mid-1970s. First, it had to rein in the 1960s' "excess of democracy" that was threatening its political power, ${ }^{254}$ second, it had to restore its profits that were eroding from the combination of intense international competition and "excessively generous" social welfare programs. Moreover, these programs, and in general all the pressures resulting from the population's relative political empowerment, were causing high inflation, which was bound to become intolerable to much of the ruling class sooner or later. In the end, the most effective way to curb inflation and to protect profits from the demands of organized labor was, first, to adopt a restrictive monetary policy (which Paul Volcker, chairman of the Federal Reserve, did in 1979) and, second, to dismantle the welfare, regulatory, and labor-accommodating regime that had been constructed between the 1930s and early 1970 s. $^{255}$ The Reagan and Thatcher administrations proceeded to do

253 See Robert Brenner, The Economics of Global Turbulence: The Advanced Capitalist Economies from Long Boom to Long Downturn, 1945 2005.

${ }^{254}$ For the liberal wing of the ruling class's perspective on the 1960 s, see Michel Crozier, Samuel Huntington, and Joji Watanuki, The Crisis of Democracy: Report on the Governability of Democracies to the Trilateral Commission (New York: New York University Press, 1975).

${ }^{255}$ A not incidental advantage of Volcker's tight money policies was that they facilitated the taming of organized labor, by raising unemployment to its highest levels since the Great Depression. 
this with gusto in the 1980s, and their successor administrations in the 1990 s and 2000 s continued their work. In the U.S., for example, union density in the private sector sank from 35 percent in 1954, and 20 percent in 1980, to less than 7 percent today. Various "free trade" acts, such as NAFTA, have been negotiated that have contributed to the decimation of organized labor in the affected countries. Daily newspaper headlines remind us of the devastation of the social safety net. Numerous studies have described how government regulation of the economy has been gutted since the 1970s, making possible the financial collapse and recession of 2008 and 2009. All this grows out of the dynamics of a corporate capitalism that is throwing off the shackles imposed on it by the nation-state-centric "compromise" (between labor and capital) of the postwar period. ${ }^{256}$

Moreover, by now the political economy of neoliberalism has spread from the U.S. and U.K. to the whole world. Libraries could be filled with the scholarship and popular writings on this subject. Naomi Klein provides a good popular overview in The Shock Doctrine (2007), which recounts the sordid tale of neoliberalism's conquest of Latin America, Eastern Europe and Russia, Southeast Asia, and the Middle East (leaving out Europe, Africa, China, and India). Through IMF structural adjustment programs, trade agreements, collaboration with authoritarian governments, and other means, the U.S. has imposed its model of a liberalized economy on the entire globe. Recently even Europe, long known for its generous

${ }^{256}$ On neoliberalism, see David Harvey, A Brief History of Neoliberalism (New York: Oxford University Press, 2005); Noam Chomsky, Profit Over People: Neoliberalism and Global Order (Toronto, Ontario: Seven Stories Press, 1999); Robert Pollin, Contours of Descent: U.S. Economic Fractures and the Landscape of Global Austerity (New York: Verso, 2003); Greta Krippner, Capitalizing on Crisis: The Political Origins of the Rise of Finance (Cambridge: Harvard University Press, 2011); David McNally, Global Slump: The Economics and Politics of Crisis and Resistance (Oakland, CA: PM Press, 2010); and Gérard Duménil and Dominique Lévy, Capital Resurgent: The Roots of the Neoliberal Revolution (Cambridge: Harvard University Press, 2004). 
social welfare provisions and healthy trade-union presence, has been shredding its former social contract. This process was underway long before the 2008 recession, but since then ruling elites have adopted the motto "Never let a crisis go to waste" and accelerated their dismantling of unions and the welfare state. The pretext, as always, is the restoration of fiscal health and national economic competitiveness. The consequences are that far fewer workers are covered by collective bargaining agreements, workplace protections are being rolled back, income inequality is rising, healthcare and education are being partly privatized, and, in general, the social fabric is being re-cut to fit the pattern of the U.S. ${ }^{257}$

The most important points about this worldwide hegemony of neoliberalism (and its associated productive forces, in particular information technology ${ }^{258}$ ) are that it is causing a resurgence of economic crisis and stagnation, and it is hollowing out the nationstate as an entity. Let's consider each of these phenomena in turn, starting with the first (which contributes to the second).

Any thoughtful observer of the neoliberal political economy has to be struck by the parallels between it and the era that culminated in the Great Depression. There is similar class polarization and vicious subjection of labor to capital, similar 'thinness' of government economic regulation, similar extreme subordination of government

${ }^{257}$ Eduardo Porter, "Americanized Labor Policy Is Spreading in Europe," New York Times, December 3, 2013; Sotiria Theodoropoulou, "European Welfare States in the Era of Pervasive Austerity," European Trade Union Institute, Brussels (draft version, August 2012); International Federation of Red Cross and Red Crescent Societies, "Think Differently: Humanitarian Impacts of the Economic Crisis in Europe" (Geneva, 2013), http://www.ifrc.org/PageFiles/134339/1260300-

Economic\%20crisis\%20Report EN_LR.pdf (accessed December 10, 2013). ${ }^{258}$ David Harvey remarks that information technology is "the privileged technology of neoliberalism," largely because it is "far more useful for speculative activity and for maximizing the number of short-term market contracts than for improving production." A Brief History of Neoliberalism, 159. 
to corporate capital, similar proneness to periodic economic crisis, similar empowerment of financial capital, and so on. ${ }^{259}$ It's true that there are differences. For example, since the 1960s or 1970s, "deindustrialization" has occurred in the West, most notably in the United States. There, employment in the manufacturing sector declined as a share of total non-farm employment from 31 percent in 1950 to 20.7 percent in $1980,13.1$ percent in 2000, and 9.1 percent in 2009. ${ }^{260}$ As Robert Brenner argues, this trend results in large part from heightened international competition since the late 1960s and consequent declines in the growth-rates of manufacturing profitability and investment. ${ }^{261}$ That is, intense international (and intra-national) competition and the resultant diminished growth of profitability have necessitated firms' feverish cost-cutting, which has meant more automation, employee layoffs, wage cuts, and outsourcing of production. The former industrial infrastructure of the West has been dismantled as firms have downsized and relocated their operations to regions with cheaper labor. In the process, industrial unionism has been destroyed, the high wages and stable jobs of what was once the core of the economy have become low wages and unstable (or nonexistent) jobs -in part because automation is making human labor superfluous ${ }^{262}$ - and a massive restructuring of the West's economy has happened.

The existence of deindustrialization only supports the broader point I want to make, that (to quote David Harvey) an "underlying problem [of] excessive capitalist empowerment vis-à-vis labour and consequent wage repression, leading to problems of effective

\footnotetext{
${ }^{259}$ See Du Boff, Accumulation and Power.

${ }^{260}$ William Strauss, "Is U.S. Manufacturing Disappearing?", Federal Reserve Bank of Chicago, August 19, 2010, midwest.chicagofedblogs.org/ (accessed November 20, 2011).

${ }^{261}$ Robert Brenner, The Economics of Global Turbulence.

${ }^{262}$ See Will Hutton, "Driverless cars, pilotless planes...will there be jobs left for a human being?," The Observer, May 18, 2013.
} 
demand," 263 characterizes both the dynamics of neoliberalism and of the political economy that eventuated in the Great Depression, which is commonly interpreted along Keynesian lines, as a product of (among other things) low effective demand. Deindustrialization has recently been a major contributor to this dynamic, and thus to the stagnation that afflicts the West and with it the world. For the loss of jobs and high wages in the manufacturing sector has not been compensated by high wages or a sufficient quantity of stable jobs in the service sector; hence, in part, the higher income inequality in the West now than fifty years ago, and the resultant lowering of effective demand. $^{264}$

Moreover, with deindustrialization, increased capital mobility since the 1960s, the demise of the Bretton Woods international regulatory framework in the 1970s, and in general the neoliberal "restoration" of capitalist class power has come a financialization of the U.S. economy even more striking than that of the 1920s. It isn't necessary to dwell on this point, since it has been thoroughly analyzed by scores of commentators. ${ }^{265} \mathrm{I}$ will only note that the financial sector's share of corporate profits in the early 2000s was around 40 percent, though since then it has declined to 30 percent. $^{266}$ Likewise, its share of GDP was 8.4 percent in 2011, compared to 2.8

${ }^{263}$ David Harvey, The Enigma of Capital, and the Crises of Capitalism (New York: Oxford University Press, 2010), 118.

264 The business press sometimes has good coverage of these "underconsumptionist" trends. See, for example, Steve Johnson, "Capital gobbles labour's share, but victory is empty," Financial Times, October 13, 2013.

${ }^{265}$ In addition to works cited above, see Andrew Glyn, Capitalism Unleashed: Finance, Globalization, and Welfare (Oxford: Oxford University Press, 2006); and, for the international context, Barry Eichengreen, Globalizing Capital: A History of the International Monetary System (Princeton: Princeton University Press, 2008).

${ }^{266}$ Jordan Weissmann, "How Wall Street Devoured Corporate America," The Atlantic, March 5, 2013. 
percent in $1950 .{ }^{267}$ As investment has shifted from the "real" economy to the more profitable financial sector since the $1970 \mathrm{~s}$ - a sector that employs far fewer people than manufacturing once didwealth and income inequality have skyrocketed, growth has stagnated, economic instability driven by speculative bubbles has increased, physical and social infrastructure has deteriorated, and unemployment has grown. Neoliberalism has meant, in short, a partial "de-development" of the United States (which in this respect is not alone among advanced industrial countries).

Processes that were in some ways similarly disempowering to the majority of wage-earners helped lead to the Great Depression, from which, as we know, ultimately emerged the Keynesian compromise between capital and labor. The national state stepped in to boost effective demand and empower labor, so keeping the system running. At the same time, nationalism, or rather the "imagined community" of the nation, continued its earlier function as a kind of ideological glue to cohere societies and ensure order: "we," both capitalists and workers, were "Americans" (or "British," or "French," or whatever) sharing a common language, a culture, a history, etc. 268 "We" were supposed to maintain allegiance to the nation and the state, i.e., to overarching power-structures, no matter how much we might disagree with one another or want a bigger slice of the economic pie than we had. To be "disloyal" was the supreme crime, and invoking that concept proved effective as a way to tar and feather "radicals." To call them Communists, for example, was to call them foreigners and subversives, which marginalized them and helped keep the capitalist order relatively stable. Thus the nationstatist compromise, which functioned ideologically as a kind of

${ }^{267}$ Justin Lahart, "Number of the Week: Finance's Share of Economy Continues to Grow," Real Time Economics (blog), Wall Street Journal, December 10, 2011, http://blogs.wsj.com/economics/2011/12/10/numberof-the-week-finances-share-of-economy-continues-to-grow/ (accessed June 1,2013).

${ }^{268}$ See Benedict Anderson, Imagined Communities: Reflections on the Origin and Spread of Nationalism (New York: Verso, 2006). 
distraction (from immediate issues of economic, social, and political empowerment), reached its classical, high modernist phase.

Since the 1970s, however, the nation-state, after many centuries of growing in power, importance, and global extent, has finally begun its long, tortured descent into crisis and collapse. The elegant irony of history is again on display: while the evolution of capitalism hitherto had contributed to the consolidation of the nation-state, at this point capital outgrew and started to shake off its old friend and enabler, who clung to it in ever more servile fashion. The state now does almost whatever it has to to stay in the good graces of the most mobile and wealthy sector of capital, finance; but other sectors, too, have found that they have a freer hand than they once did.

Again, the essential condition of this shift in the balance of power has been the spectacular increase in capital mobility since the 1960 s, made possible by the rise of new productive forces, in particular electronic technology. Actually, even apart from its enabling the ascendancy of transnational corporations and global finance, this technology is playing an important role in the downfall of the nation. Just as "print-capitalism" after the fifteenth century contributed to the rise of the nation-state (as Benedict Anderson argues), what one might call "electronic capitalism" is contributing to its fall. To be sure, the imagined community of the nation is declining faster than the national state itself. The community is fragmented by electronic media, which, at least in the context of capitalism, tend to substitute isolation and self-involvement for direct interaction with others, as well as to degrade communication into instantaneous visual and auditory stimuli whose effect is to undermine identities (be they personal, national, or whatever). To quote myself again:

These trends [of national disintegration] are evident when one considers the impact of television, video games, cell-phones, computers, the internet, and such "social media" outlets as Twitter and Facebook. A society in which most people spend an inordinate amount of their time sitting in front of TVs, playing video games, shopping online, 
searching for soulmates through internet dating, imbibing bits of information in short bursts from an endless variety of global news and entertainment sources, and electronically "chatting" with acquaintances or strangers located anywhere from the next room to the other side of the world - such a society does not have much of a tangible national culture, and its "imagined community" is indeed imaginary, a mere abstraction with little basis in concrete reality. In short, the individualistic, passive, and consumerist nature of a capitalist society saturated by electronic media ${ }^{269}$ is interpersonally alienating and destructive of civil society, hence destructive of a shared national consciousness. ${ }^{270}$

Moreover, the fact that electronic technology makes possible nearly instantaneous communication across the world means that the kind of community it fosters is global rather than national. One may start to feel more affinity for people ten thousand miles away than for one's compatriots. Global social movements become easier to coordinate; things like the Arab Spring and Occupy Wall Street can emerge to break down national barriers and birth a global consciousness.

The worldwide hegemony of finance and the transnational corporation is similarly destructive of traditional civil society, and thus of the nation. For it has contributed to deindustrialization in advanced countries, the virtual destruction of organized labor, the rise of a "precariat" of insecure workers living on society's margins, the erosion of the welfare state, the privatization of such public resources as education and the natural environment, the decline of Keynesian stimulation of demand (largely because investors fear its inflationary consequences), the hollowing out of state regulation of the economy, the onset of economic crisis and stagnation, degradation of the natural environment, etc. All these circumstances

${ }^{269}$ And by "print versions" of such media, for example magazines devoted to celebrity gossip and instant gratification of whatever sort.

${ }^{270}$ Wright, Notes of an Underground Humanist, 168. 
tend to bring about a relative equality of conditions between countries, as a creeping Third-Worldization of the West occurs. The very idea of "America" or "Britain" or "France" — a substantive national community that differs from others - becomes threadbare, a transparent fig leaf for the naked pursuit of power by moneyed elites.

The state, too, is in decline, though perhaps less obviously than the idea of the national community. The reason is simply that the global community of capitalists will not let the Western state reverse its post-1970s policies of retrenchment, which is the only way for it to adequately address all the crises that are currently ripping society apart. If any state - unimaginably - made truly substantive moves to restore and expand programs of social welfare, or to vastly expand and improve public education, or to initiate programs like Roosevelt's Works Progress Administration or Tennessee Valley Authority (but on a necessarily broader scale than in the 1930s), or to restore organized labor to its power in the 1960s and thereby raise effective demand, or to promulgate any other such anti-capitalist measure, investors would flee it and its sources of funds would dry up. It couldn't carry out such policies anyway, given the massive resistance they would provoke among all sectors and levels of the business community. Fiscal austerity is, on the whole, good for profits (in the short term), since it squeezes the population and diverts money to the ruling class. In large part because of capital's high mobility and consequent wealth and power over both states and populations, the West's contemporary political paradigm of austerity and government retrenchment is effectively irreversible for the foreseeable future.

This raises an obvious question: how is the state to deal with social discontent? In the $1930 \mathrm{~s}$ and $1940 \mathrm{~s}$, states adapted to discontent mainly by becoming more inclusive and increasing their control over capital. ${ }^{271}$ But since that is no longer an option, what's

${ }^{271}$ In many cases, of course, they tried the fascist route first, hoping to crush the left. After that led to near-armageddon they had to go the more democratic route, to some extent incorporating the left and the working class into the state. 
the solution? Evidently the most immediate and urgent response is repression. This is the natural instinct of every power-structure when confronted by resistance: destroy it, stamp it out, for instance by imprisoning people, demonizing dissidents as "extremists" or "terrorists," and deploying police forces to smash popular movements. So far this has been, and will probably continue to be, the predominant political response to the contemporary crisis. A quasi-police state is taking the place of the welfare state, as can be seen from governments' investment in "national security," greater powers of surveillance, the expansion and privatization of the prison system, the militarizing of police forces, ${ }^{272}$ the ever-more-frequent suspension of civil liberties, etc. These measures do not signify the health of the state; they are its desperate response to a terminal illness. National governments are being hamstrung and privatized by capital even as their subject populations are rising up in revolt. The only recourse, it seems, is to militarize society-i.e., to expand one of the few government powers capital doesn't object to, the power to suppress democratic resistance.

In short, durable "compromises" between labor and capital are no longer possible. Only the nation-state could be a framework for such a compromise, because only national governments (not local or regional) potentially have the power to stand up to corporate capital and regulate it. But they have lost this power on the scale necessary since the 1970s. So what will ensue in the coming decades is a global conflict between the capitalist hyper-elite - together with its political minions - and the majority of the species, a conflict that this time will not be resolved by the principle of nationality, because it is dying. Almost two hundred years after the Communist Manifesto, Marx's time has arrived. The time for true internationalism, which is to say transnationalism, in anti-capitalist (and anti-statist)

\footnotetext{
${ }^{272}$ See, e.g., Arthur Rizer and Joseph Hartmann, "How the War on Terror Has Militarized the Police," The Atlantic, November 7, 2011.
} 
movements has arrived, at long last. ${ }^{273} \mathrm{~A}$ hundred years ago there was no such internationalism in labor movements, as the two nationalist world wars - largely supported by organized laborshowed. Nor was there in the context of the Cold War, as the reactionary and imperialistic stances of the U.S.'s AFL-CIO showed. Only since NAFTA, and especially since the Seattle demonstrations against the WTO in 1999, have labor unions and social movements in general really begun to realize their internationalist potential. ${ }^{274}$

A leader of Brazil's Landless Workers' Movement says it well: "It is very striking that it is only now that farmers are starting to achieve a degree of worldwide coordination, after five hundred years of capitalist development... The new phase of capitalism has itself created the conditions for farmers to unite against the neoliberal model." ${ }^{275}$ And the neoliberal model, to repeat, is not some drastic new departure but only the logical conclusion of tendencies that have operated in capitalism for many centuries, namely privatization, marketization, the commodification of everything, suppression of workers' power, class polarization, integration of the world under the aegis of capitalist relations of production, and ever-increasing capital mobility. These tendencies have finally reached the point that they are consuming nation-states and making both possible and necessary globally coordinated resistance in the form of transnational social movements. This global confrontation with capital, in fact, is really what Marxism was all about to begin with. The slogan "Workers of the World, Unite!", far from being outdated, has become more timely and necessary than ever before.

\footnotetext{
273 "Trans" means through; "inter" means between. We need social movements that operate through and around nation-states, not only between them or on the basis of them. We need movements organized globally.

${ }^{274}$ Tamara Kay, NAFTA and the Politics of Labor Transnationalism.

${ }^{275}$ Quoted in Annette Desmarais, "La Via Campesina," in Rural Social Movements in Latin America: Organizing for Sustainable Livelihoods, eds. Carmen Diana Deere and Frederick S. Royce (Gainesville, FL: University Press of Florida, 2009), 37, 38.
} 
There is much more to be said about the decline of the nationstate, but I'll skip to the main point: what the retrenchment of government's public functions is making possible, for the first time ever, is the paradigm of revolution that I described above when critiquing Marx's theory. Given the state's growing incapacity to assuage discontent, movements of a decentralized, semi-interstitial, regional, democratic character are emerging to fill the vacuum. In the long run they, or the institutions they spawn, will probably take over many of the functions of the national state, such as the provision of social welfare. Even more importantly, they will enable the construction of new production relations in the shell of a corporate capitalist economy that cannot provide billions of people with a livelihood. These relations will spread all over the world, in an agonizingly slow process that will surely take well over a hundred years-because social transitions on the scale of capitalism-to"cooperativism" do not happen quickly.

But how will such a transition happen? I'll address this question empirically in the following section, but here I can at least outline the historical logic. Marxists and other radicals often object that the sorts of developments I'll describe shortly are merely interstitial and unpolitical, can be co-opted by the ruling class, can function as stabilizing forces for society, are compelled to compromise with capitalism, and therefore do not represent viable paths to a postcapitalist future. There may, indeed, be some truth to these objections when the social context is one of basic systemic stability, i.e., when society isn't in a "revolutionary situation" anyway. But when it is - when the social fabric is disintegrating, economic crisis is throwing millions out of work, class polarization is growingthese "interstitial" developments can potentially have revolutionary significance. The logic is that as political protest spreads and the ruling class grows ever more fearful, some of its more progressive members and institutions split off from the rest and throw their support to un-capitalist or semi-capitalist initiatives as a desperate way to keep the masses obedient and society under control. Again, this is how the New Deal state was born in the U.S. But since such a state is not an option anymore, the ruling class's hopes for stabilizing 
society will, by and large, lie in more localized and decentralized democratic experiments (in addition, as I said, to political repression). The combination of mass agitation and ruling-class support will ensure that these experiments spread, especially because in all likelihood there will be no foreseeable end to the economic crisis. In the long run, the result will be capitalism's selfundermining by means of its forced support for a proliferation of people-empowering measures. Their popularity and success, moreover, will generate a dynamic by which they spread of their own momentum, so to speak. The success of the new "bottom-up" economy will make the old top-down one increasingly obsolete, though of course innumerable political clashes will have to occur before it can be unseated from the summits of power.

In short, the state and ruling class will, whether consciously or not, adopt two overarching strategies to maintain their power: try to repress dissidents, and assist progressive initiatives that seem comparatively unthreatening. In "liberal" societies confronted by massive and sustained protest, such a dual approach is necessary, because repression alone is unsustainable, does not address the underlying causes of protest, and (as the government's sole strategy) is unacceptable to large portions of the public and the elite. On local, regional, and national scales, the ruling class will try to smash radical movements even as it (or a section of it) tentatively supports such things as public banking, municipal enterprise, cooperatives, enlightened use of eminent domain, ${ }^{276}$ and communal self-help institutions of various kinds. But political dissidence will, if anything, only spread, not go away. One can expect that, in a world of multiform crisis, alliances will naturally emerge between different movements on the left some of which are less explicitly challenging to the capitalist state than others. The progress of so-called "unpolitical" initiatives, therefore, will aid the progress of the more

${ }^{276}$ See Shaila Dewan, "A City Invokes Seizure Laws to Save Homes," New York Times, July 29, 2013; and Peter Ranis, "Occupy Wall Street: An Opening to Worker-Occupation of Factories and Enterprises in the U.S.," MRZine, November 9, 2011, http://mrzine.monthlyreview.org. 
political movements, and vice versa, such that corporate capitalism will be slowly hollowed out even as it loses ideological hegemony. Its opponents will command more and more resources, which itself will make possible their command over even more resources, in a self-reinforcing cycle somewhat comparable to the early-modern bourgeoisie's gradual erosion of feudalism's (and later absolutism's) economic, political, and ideological hegemony. The more economic success one has, the more resources one has, which means the more propaganda one can churn out and so attract people to one's agenda.

As for the question whether alternative economic institutions can indeed be more "successful" than capitalist ones, that is to say more productive and socially equitable: one of the purposes of this book is to show that they can. Cooperatives, as we've seen, can be more effective than conventional businesses even by the narrow standards of capitalism. We shouldn't necessarily condemn co-ops for having to work within the confines of capitalism, for if they become common and network with each other and other progressive organizations they might prove to be of great use to left-wing political movements, by providing them with resources and spreading an anti-capitalist ethos. Furthermore, as greater numbers of co-ops support one another, each will be less shackled to the logic of capitalism. The economic success of these and other alternativeeconomy institutions - in part a result of their mutual support — will then serve as its own public-relations campaign, so to speak, attracting people to new models and thus contributing to the spread of alternative modes of production beside the old dysfunctional capitalist mode.

Another way to conceptualize the coming social transformations is to return to the idea that the main problem the economy is facing is low effective demand. The question, then, is how to comprehensively raise demand. We know that the old Keynesian solution was high government spending and high wages for workers, but both those options are off the table in an era of austerity, government privatization, and neoliberal globalization. Keynesianism on the colossal and international scale necessary is simply out of the question. The only other solution, and the only 
appropriate one in an age of decaying nation-states, is to construct new, non-statist social relations that economically empower people, i.e., raise demand. To repeat, what many of these will ultimately amount to are new production relations, on the basis of which will, necessarily, arise new social and political structures. Thus, virtually by analytical necessity it is evident that profound social revolution offers the only way out of the contemporary economic crisis. The slowness of the revolution is what will allow members of the ruling class to support it, for it will appear that all they are doing is defusing mass unrest by means of piecemeal reforms. But these reforms will be of a very different character from those of the earlier welfare state. Rather than being essentially corporatist, i.e., giving greater power to a national state that is integrated into corporate capitalism, they will consist of a democratic transformation of social relations "from the ground up."

Of course the national state isn't going away anytime soon. In fact, it will likely have to become more inclusive in the coming decades in order to adapt to social crisis. However, the ways in which it becomes inclusive will be relatively new: given the different political economy we live in than sixty years ago, they will be less centralized and less corporatist, involving a devolution of governmental powers and greater international coordination on multiple levels of governance.

\section{Practice}

In the tradition of Marxism, we'll follow our theoretical discussion with a focus on practice, which is, if anything, more important than theory. The point is to change the world, not just to interpret it. This whole book pertains mainly to practice, but in this section I'll focus not on worker co-ops in the U.S. but other initiatives springing up around the world. Needless to say, there are many to choose from. People and governments everywhere are experimenting with alternative economic, social, and political arrangements. Some of these will not last long or will prove to be of limited importance; others may end up serving as models for a future 
society. In the following I'll describe some initiatives that strike me as particularly promising and interesting.

A reasonable starting point is Quebec's social economy, which is a sophisticated set of interlocking institutions that has matured since the 1980s. The term "social economy" just refers to the third sector in economies, between the private and the public sector. It is composed of such things as housing associations, civic societies, nonprofits, charities, cooperatives, and credit unions-institutions that are at least in part run by community members and exist not to pay profits to shareholders but to benefit communities, the environment, and marginalized groups. The social economy has ethical aims, but, as we have seen with cooperatives, the seemingly opposed imperatives of ethics and "efficiency" are by no means mutually exclusive. Very often one finds that the more ethical an institution is, the more profitable, productive, and efficient it is. Likewise, bureaucracy, gigantic size, and slavishness to the interests of big capital not only are immoral (inhumane and undemocratic) but have costs even by the narrow standards of efficiency and effectiveness. Being run by people whose goals are ethical, the social economy contributes to job creation, the provision of services, the production of goods, community revitalization, and in general sustainable development. ${ }^{277}$

Quebec's social economy is famous, and has been intensively studied, because of its sophistication and effectiveness. I won't describe it in great detail here, but it comprises over 7000 organizations that provide an array of services to the population. A watershed moment for it occurred in 1996, when the state invited representatives of all these actors - among which are "citizen's committees, food banks, community centers, family economy cooperative associations, community health clinics, legal clinics, not-

${ }^{277}$ Social Economy Lisburn, "What is Social Economy?" http://www. socialeconomylisburn.org. 
for-profit childcare centers, ${ }^{278}$ housing co-ops, women's centers, workers' co-ops, community economic development corporations, labor unions, and environmental associations - to participate in a conference on the future of Quebec in light of its problems with unemployment and economic development. The result was the subsequent institutionalized collaboration between the state at all levels and these diverse organizations, a collaboration that "involve[s], among other things, making it much easier for non-profit associations engaged in social economy activities to acquire the necessary financial resources, through government grants, indirect subsidies, or access to credit; the creation of a social economy office within the provincial government; and the consolidation of an umbrella organization in civil society, the Chantier de l'économie sociale, to coordinate strategies for enlarging and deepening the role of the social economy." ${ }^{279}$ Few social economies in the world have achieved this degree of institutional coherence and coordination, which explains why activists and policymakers have been so intrigued by the Quebec model.

In general, the global social economy can be expected to grow in the next fifty years, as national governments prove less capable of fulfilling their welfare and regulatory functions. Quebec's social economy, for example, continues to grow in extent and access to capital. A recent innovation was the creation in 2007 of the Fiducie du Chantier de l'économie sociale, "a $\$ 53.8$ million patient capital or quasi-equity fund to enable collective enterprises to embark on longterm planning, invest in real estate, and move out of a vicious cycle

\footnotetext{
278 Marguerite Mendell, "The social economy in Quebec" (2003), http://unpan1.un.org/intradoc/groups/public/documents/clad/clad0047506.p $\frac{\mathrm{df}}{279}$ (accessed May 23, 2010).

${ }^{279}$ Erik Olin Wright, Envisioning Real Utopias (New York: Verso, 2010), 204-205. See also Marguerite Mendell, "The Social Economy in Quebec: Lessons and Challenges for Internationalizing Cooperation," in $\mathrm{Co}$ operatives in a Global Economy, 226-241.
} 
of debt." ${ }^{280}$ A couple years later, a financial network called CAP Finance was established to connect microcredit organizations, local development funds, large "labor solidarity" funds, and so on. The mainstream economy's recent travails have not hindered any of this activity; on the contrary, "amidst the debris of speculative financial markets" it has become easier to interest investors in the Fiducie's stable rates of return. ${ }^{281}$

Europe's social economy is just as vital as Quebec's. As reported in 2012 by the European Economic and Social Committee (EESC), the social economy accounts for over 14.5 million jobs and about 6.5 percent of total paid employment in Europe. ${ }^{282}$ Since the last quarter of the twentieth century the social economy has grown considerably, so that it is increasingly taking the place of the state in creating employment and correcting economic and social imbalances. It is also achieving greater recognition as an important actor in European affairs, as reports on it are published by the EESC, the UN declares the social economy to be crucial for global development, Europewide statutes for cooperatives are adopted, conferences on cooperatives and the social economy are organized, new legal forms are created to accommodate social enterprises, university courses on the social economy appear, and, in 2012, a social economy minister is appointed in France's government. As in Quebec, this sector of the economy is faring relatively well in conditions of economic stagnation; for instance, it has been able to deploy "its own alternative forms of solidarity funding, such as ethical banking, social currencies or the credit unions, which are not only providing

${ }^{280}$ Marguerite Mendell, "Financing the Social Economy in Quebec" (2010), 48, at http://communityrenewal.ca/sites/all/files/resource/MW200346.pdf (accessed May 21, 2013).

${ }^{281}$ Ibid., 50.

${ }^{282}$ José Luis Monzón Campos and Rafael Chaves Ávila, “The Social Economy in the European Union," 46, http://www.ciriec.ulg.ac.be /fr/telechargements/RESEARCH_REPORTS/EESC -

CIRIEC_Report 2012 def_ENG.pdf (accessed May 21, 2013). 
credit but are also generating trust in its financial services." ${ }^{283}$ Similarly, employment levels are proving more stable than those of the private sector. It's true that recent cutbacks in public spending have had a damaging effect, but they have been far from devastating.

A few random figures indicate the sector's vitality. In France, the social economy (which accounts for 10 percent of salaried employment) created 18 percent of all new jobs between 2006 and 2008. Its employment level increased by 2.9 percent $(70,000$ new jobs) between 2008 and 2009, while in the private sector it sank by 1.6 percent and in the public sector by 4.2 percent. Similarly, in Italy, employment in cooperatives increased by 8 percent between 2007 and 2011, while in the conventional private sector it decreased by 2.3 percent. In Spain, too, employment in worker cooperatives grew by 4.7 percent in 2011, as it dropped in the rest of the private sector for the fourth consecutive year. ${ }^{284}$

Related to the social economy, and often considered a part of it, is the solidarity economy, which tends to be a little more political and anti-capitalist than the social economy as a whole. The values that inspire its participants are the opposite of capitalist: community, egalitarianism, and democracy. Like its more well-known cousin, the solidarity economy started growing exponentially in the last quarter of the twentieth century, as neoliberalism ravaged Latin America and other parts of the world. The solidarity economy's chief impetus came from social movements in Latin America, which has a long history of peasant- and indigenous-based resistance to Western imperialism. In the past, this resistance helped bring about things like the Mexican and Cuban revolutions, the "developmentalist" period of South American history between the 1930s and 1960s, Chile's dalliance with a kind of democratic proto-socialism in the early 1970s (until it was crushed by the U.S. and Pinochet), and attempts at revolution in Central America in the 1980s. Since the 1990s, it has

\footnotetext{
${ }^{283}$ Ibid., 87.

${ }^{284}$ European Commission, Directorate-General for Employment, Social Affairs and Inclusion, "Social Economy and Social Entrepreneurship" (Luxembourg: Publications Office of the European Union), 53.
} 
birthed Latin America's turn to the left (for example with the elections of Hugo Chavez, Lula da Silva, Evo Morales, Rafael Correa, and Daniel Ortega) and helped birth such global movements as fair trade, solidarity lending, the expansion of cooperativism and credit unions, the World Social Forum and its offshoots, and La Via Campesina. Among the practices that are often mentioned in the context of the solidarity economy are community-supported agriculture, urban gardening, alternative currencies, collective kitchens, and community land trusts, not to mention all the more familiar forms of cooperativism (producer, consumer, housing, agricultural, etc.).

Before going into more detail about some of these phenomena, it will be worthwhile to consider just how significant the solidarity economy and its conceptual relatives are becoming. In a sense, after all, the term is nothing but a name for the ideal that all "radicals" are fighting for: it is socialism, anti-capitalism, cooperativism, economic democracy, whatever your preferred name is. The post-capitalist economy will have to incorporate the "solidarity" structures that are emerging, and in fact it will be grounded in them. Especially if you broaden the concept of solidarity economy so that it encompasses public banking, municipal enterprise, benefit corporations, and participatory budgeting (all to be discussed below), its contemporary significance is undeniable. It is, in short, the terrain of the "movement of movements" against privatization and profitmongering, aimed at the resurrection of public space, whether embodied in the World Social Forum, Occupy Wall Street, or any of the countless dissident movements rocking the globe.

A clear indication of the growing importance of the solidarity economy is its ever-greater institutionalization. A rather primitive gauge of this is the proliferation of relevant websites, such as yesmagazine.org, geo.coop, shareable.net, aloe.socioeco.org, ripess.org, community-wealth.org, en.solecopedia.org, uwcc. wisc.edu, and american.coop. More substantively, dozens of international networks have been formed recently to facilitate organizing and education, including Alliance for a Responsible, Plural and Solidarity Economy (ALOE), the Intercontinental 
Network for the Promotion of the Social Solidarity Economy (RIPESS), the U.S. Solidarity Economy Network (SEN), the Asian Alliance for Solidarity Economy, the European Institute for Solidarity Economy (INESS), and many organizations in Latin America. One must include all the social forums that exist even in the conservative U.S.: the U.S. Social Forum, the Midwest Social Forum, the Social Forum of the Americas, the European Social Forum, etc. Like their progenitor the World Social Forum, which began in 2001 and has met annually, these are essentially periodic conferences where activists and organizations involved in the alterglobalization movement can come together to share ideas, strategies, and experiences, attend workshops and lectures, network and seed new institutions. The WSF regularly draws more than 60,000 participants from around the world. ${ }^{285}$

Perhaps even more striking than the proliferation of all these networks, organizations, and conferences is the recognition that the solidarity economy is receiving from governments. I already mentioned the creation of the new post of Minister for the Social Solidarity Economy in the French government. Compared to Latin America, though, France is behind the times. For example, in 2003 Brazil's president Lula established a National Secretariat of the Solidarity Economy, and cooperatives receive financial support from the ministries of Agricultural and Social Development. The Brazilian government also funds university programs that provide local groups with training and support to set up cooperatives or social enterprises, "similar to business incubators in the U.S." ${ }^{286}$ (Cooperative business programs are starting to appear in North American universities too.)

\footnotetext{
${ }^{285}$ See José Corrêa Leite, The World Social Forum: Strategies of Resistance (Chicago: Haymarket Books, 2005), and William Fisher and Thomas Ponniah, eds., Another World Is Possible: Popular Alternatives to Globalization at the World Social Forum (New York: Zed Books, 2003).

${ }^{286}$ Emily Kawano, "Report from the 1st Solidarity Economy Social Forum \& World Fair, Santa Maria and Porto Alegre, Brazil-Jan 22-29, 2010," SolidarityEconomy.net, http://www.solidarityeconomy.net (accessed May 25, 2010).
} 
Ecuador went a step further in 2008: it adopted a constitution that draws from the social and solidarity economy (SSE) model for development, in that it formalizes commitments to food sovereignty, the use of land for social and environmental functions (forbidding large estate farming, land concentration, and the privatization of water), a "decentralized national system of participatory planning" for development, and numerous other progressive principles that are fleshed out in very concrete ways. Bolivia's 2009 constitution is similarly progressive. Public policy initiatives on the SSE have been flowering in Venezuela, Mexico, Argentina, Chile, Peru, and elsewhere, under the pressure of growing social movements.

Governments in Africa and Asia are likewise facilitating the growth of the SSE, though I can't review all the relevant policies here. The South African government, for example, has passed legislation to boost cooperatives, and, as of 2012, further legislation to establish a cooperative council, academy, and development agency has been proposed. ${ }^{287}$ Africa's tenth ministerial conference on the theme of cooperatives was held in Rwanda in 2012; 27 countries committed to passing laws to support the SSE, expanding education regarding the creation and sustainability of co-ops, increasing regional cooperation and trade among co-ops, and possibly creating integrated financial cooperatives at country and regional levels. ${ }^{288}$ Prime Minister Erdogan of Turkey launched in 2012 a national cooperative strategy and plan of action to fundamentally restructure the cooperative sector so as to make it more effective, competitive, and sustainable. ${ }^{289}$ India and Indonesia

${ }^{287}$ Susan Steinman and Jerome von Rooij, "Developing Public Policies for the Social and Solidarity Economy in South Africa: The Need for a State Civil Society Dialogue," Universitas Forum, Vol. 3, No. 2 (2012).

${ }^{288}$ ICA, "African Ministers agree to support cooperatives," November 27, 2012, at http://ica.coop/en/media/news/african-ministers-agree-support-cooperatives (accessed May 31, 2013).

${ }^{289}$ See "Turkish Cooperatives Strategy and Action Plan 2013-2016," a report from the Directorate General of Cooperatives in Turkey's Ministry of Customs and Trade, http://www.turkiye2012koop.org. 
have recently reformed their laws regarding co-ops. Since the early 2000s, the Russian government-at all levels - has actively supported the cooperative movement. ${ }^{290}$ Indeed, on the whole it seems there are few governments in the world that do not provide notable support, and are not increasing their support year by year, for the social and solidarity economy.

The UN and its specialized agency the ILO have been taking action too; in fact, they have facilitated many of the policy initiatives just mentioned. I noted in the Introduction that the UN declared 2012 the Year of the Cooperative. What this designation concretely meant was a year of intense advocacy and organizational support for coops, so as to publicize their worldwide impact on poverty reduction, social integration, and socioeconomic development. (The website social.un.org/coopsyear showcases the UN's work in this area.) As the UN sponsors international summits, forums, ministerial conferences, film festivals, and other events to spread the ideology of cooperativism, the ILO publishes in-depth reports, sponsors cooperative projects, aids in the formation of policy, and helps organize conferences like the SSE Academy, which began in 2010. The SSE Academy is "an inter-regional training event bringing together more than 100 [in fact as many as 300] practitioners and policy-makers from around the world, to share their experiences and meet leading SSE specialists." ${ }^{291}$ Among other achievements, the 2013 conference helped further the ILO's initiative to establish an Interagency Task Force in the United Nations that would bring "relevant UN agencies together for regular exchanges on their programming and policy making in the field of SSE."

As for the actual practices of the solidarity economy "on the ground," I can at best hope merely to gesture at a few examples in the limited space here. The classic example is Brazil's Landless

\footnotetext{
${ }^{290}$ ILO, Cooperative Sector in Russia (Geneva: International Labour Office, 2009).

${ }^{291}$ ILO, "Partnerships for Decent Work Newsletter," http://www.ilo.org.

${ }^{292}$ The Canadian CED Network, "UN Social and Solidarity Economy Conference Yields Rich Results,” http://ccednet-rcdec.ca/en/node/11983.
} 
Workers' Movement (MST), which began in 1984 and now has a membership of almost two million people. Its main political goal is to bring about national agrarian reform that eliminates the extreme inequality in ownership of land; much of its activity consists of occupying unused land and establishing encampments on it, which become permanent settlements if the occupiers gain legal ownership. The encampments and settlements can be organized on the basis either of family ownership or of collective ownership, depending on the decisions of local assemblies. Each settlement is structured as a mini-society (with extensive ties to other settlements and to state, regional, and national leaders), which collectively decides how the settlers' income is to be spent-how much will go to production, health care, schooling, and so forth. The MST as a whole has established hundreds of agricultural cooperatives that take in more than 50 million dollars a year, some of which goes to the 20 million dollar budget for social services and infrastructure, the rest of which goes directly to member families. The movement also has founded teacher-training programs in national universities, hundreds of daycare centers, an agricultural college, almost two thousand primary and secondary schools, several credit cooperatives, 96 food processing plants, a clothing factory, etc.-all of which is ancillary to its main achievements of organizing over 250,000 occupations and winning land for over 350,000 families in two thousand settlements (as of 2009), in addition to the 200,000 families that are currently occupying land but do not yet legally own it. As a result of all this success, the MST has won international recognition, receiving grants from UNESCO and UNICEF and awards from the UN. ${ }^{293}$

The MST clearly parallels the solidarity economy in general: it is both a model of a future democratic, socialist society and a means of bringing it about. More specifically, as activist Ethan Miller says, the

${ }^{293}$ Laura Landertinger, "Brazil's Landless Workers Movement (MST)," 2009, http://www.yorku.ca/cerlac/documents/Landertinger.pdf (accessed May 31, 2013); Miguel Carter, "The Landless Rural Workers' Movement and the Struggle for Social Justice in Brazil," in Rural Social Movements in Latin America, 88. 
means to the end is that "building relationships between solidaritybased enterprises and larger social movements builds increased support for the solidarity economy while allowing the movements to meet some of the basic needs of their participants, demonstrate viable alternatives, and thus increase the power and scope of their transformative work." ${ }^{294}$ That's my argument in a nutshell. It's worth noting, incidentally, that the MST belongs to the Brazilian Solidarity Economy Forum, which "works on an even broader scale [than the MST], incorporating [as of 2006] twelve national networks and membership organizations with twenty-one regional Solidarity Forums and thousands of cooperative enterprises to build mutual support systems, facilitate exchanges, create cooperative incubator programs, and shape public policy." ${ }^{295}$ This is the revolution in action.

A broad category, and a particularly well-known one, of the solidarity economy is the movement known as Fair Trade, which has expanded significantly in recent years. As defined by the World Fair Trade Organization (in association with Fairtrade International, the Network of European Worldshops, and the European Fair Trade Association), Fair Trade is a "trading partnership, based on dialogue, transparency and respect, that seeks greater equity in international trade. It contributes to sustainable development by offering better trading conditions to, and securing the rights of, marginalized producers and workers-especially in the South." 296 More specifically, it "promotes standards for production practices and delivery procedures, working conditions and labour remuneration, environmental care and social policies in supply chains of certified

${ }^{294}$ Ethan Miller, “Other Economies Are Possible!”, ZNet, September 9, 2006, http://www.zcommunications.org/other-economies-are-possible-byethan-miller (accessed May 31, 2013).

${ }^{295}$ Ibid.

296 World Fair Trade Organization, "What is Fair Trade?," http://www.wfto.com/index.php?option=com content\&task=view\&id=1\&It emid=13 (accessed June 17, 2013). 
goods." 297 The Fair Trade Labeling Organization (FLO) was established in 1997 to set standards worldwide and certify that particular products embody these standards. Among the growing range of goods that the certification system can cover are coffee, bananas, sugar, oranges, tea, chocolate, wine, rice, honey, flowers, cosmetics, and clothing. As the Fair Trade movement has gone mainstream, with large retailers selling certified products, the worldwide volume of sales has increased; in 2011, for example, sales were up to 6.6 billion dollars, 12 percent higher than the previous year. $^{298}$

The way Fair Trade works is quite complex, but the main point is that for a product to be Fairtrade-certified it has to have been produced and traded under conditions characterized by, for instance, the absence of child labor and forced labor, workers' freedom to unionize, compliance with ILO conventions on working conditions, respect for the environment, commitment to gender equity and poverty reduction, and the importer's payment to the producing organization (e.g., an agricultural cooperative) of both a specified minimum price and a premium. The minimum price helps shield farmers from the volatility of world markets, while the premium goes into a fund that farmers and workers can use for community purposes, as they see fit. Producers and traders who want to sell Fairtrade-labeled products have to pay a fee to FLO, which inspects them to certify that they adhere to the requisite standards.

Studies have shown that, so far, Fair Trade (FT) has had mixed results in terms of improving local conditions and empowering farmers and workers. On the one hand, "guaranteed Fair Trade market outlets and stable prices provide incentives to producers to realise on-farm investments, intensify input applications and enhance

${ }^{297}$ Ruerd Ruben, "The development impact of Fair Trade: from discourse to data," in The Impact of Fair Trade, ed. Ruerd Ruben (The Netherlands: Wageningen Academic Publishers, 2008), 19.

298 Natalie Huet, "Fairtrade sales to grow as consumers demand better labelling," Reuters, February 28, 2013, http://uk.reuters.com. 
labour use. ${ }^{299}$ FT associations and cooperatives can provide farmers with technical assistance and administer social and environmental projects made possible by the FT premium. Land and labor productivity are thereby raised above those of non-FT producers, which translates into higher household income and willingness to invest in long-term projects. According to some studies, FT producers report a greater sense of well-being and a more positive outlook for their future than non-FT producers do. Nutritional standards are higher and infant mortality rates lower than in households without access to Fair Trade organizations. Participation in Fair Trade has been found to reduce farmers' economic vulnerability, assist in poverty reduction, enhance family stability, improve children's education, strengthen the role of women in their community, and benefit the natural environment. ${ }^{300}$

On the other hand, these positive effects are not universally observed, in part because the certification process is not foolproof and FT standards are not consistently enforced. There are relatively few impact studies of Fair Trade, and the ones that exist do not always have sound methodologies. One thing known for sure is that few FT producers are able to sell most of their product to FT outlets, because of insufficient demand. Fair Trade is still a very small fraction of global trade even in such commodities as coffee and bananas; about 1.5 million farmers and workers around the world participate in it. ${ }^{301}$ In 2011, FT producer revenues in the export of coffee, bananas, cocoa beans, and cane sugar were less than 1

299 Ruerd Ruben et al., "Fair Trade impact of banana production in El Guabo Association, Ecuador," in The Impact of Fair Trade, 155.

300 Stephanie Geiger-Oneto and Eric J. Arnould, "Alternative Trade Organization and Subjective Quality of Life: The Case of Latin American Coffee Producers," Journal of Macromarketing, Vol. 31, No. 3 (September, 2011): 276-290. The WFTO-Europe provides links to many studies at http://www.wfto-europe.org/lang-en/documents.html (accessed June 21, 2013).

${ }^{301}$ Felicity Lawrence, "Fairtrade shouldn't all be down to the consumer," The Guardian, February 26, 2012. 
percent of the global value of exports (although FT markets are growing at a brisk pace). ${ }^{302}$ Some critics worry, too, that as FT becomes more mainstream, it is losing its commitment to the values that originally sustained it. Other common criticisms are that FT doesn't necessarily benefit migrant laborers, that its impact on nonFT producers is ambiguous at best, that the premiums consumers pay do not always directly benefit farmers, and that FT's consumerdriven model means it "cannot address the core problem of excessively concentrated markets in which a handful of overpowerful transnational corporations dictate terms of trade and suck profits up into their own coffers."

Insofar as there is justice to these criticisms, the best answer to them is probably the one that applies to all initiatives in the solidarity economy: they cannot realize their transformative potential unless backed up by social movements. But if they are, and if the capitalist state feels existentially threatened so that it has to tolerate and support them, then they can indeed be components of systemic change. Fair Trade has already raised consciousness in the global North, making people more aware of conditions in the South and proving that consumers are willing to pay extra for products if doing so benefits farmers and workers. The task now is the admittedly difficult one of making the movement more mainstream while simultaneously shoring up its commitment to strict standards of producer empowerment. As producers improve their living standards, get access to more resources, and develop a greater sense of collective self-worth, they will have more success in pressing for political changes in their own countries. Fair Trade can also potentially assist in building solidarity movements in the North, and

${ }^{302}$ Kimberly Ann Elliott, "Is My Fair Trade Coffee Really Fair?," Center for Global Development, Policy Paper 017, December, 2012, http://www.cgdev.org/doc/full text/policyPapers/1426831/Is-My-Fair-

Trade-Coffee-Really-Fair.html (accessed June 21, 2013).

${ }^{303}$ Felicity Lawrence, "Fairtrade shouldn't all be down to the consumer"; Colleen Haight, "The Problem with Fair Trade Coffee," Stanford Social Innovation Review, Vol. 9, No. 3 (Summer 2011): 74-79. 
it can provide issues on which to pressure governments-and resources by which to do so. It's true, though, that ultimately the main component of systemic change is the transformation of the class structure, and here Fair Trade, in its current form, must play a subordinate role. The main strategic emphasis has to be on movements that directly attack the power of transnational corporations and aim to bypass them by organizing economic activity through different paths. What those paths will be is still not clear.

There are obvious possibilities, however-and even obvious necessities. As John Restakis argues, any future moral-and sustainable - regime of global trade will have to give a central place to agricultural cooperatives of the sorts that already exist across the South (and North). Only cooperatives, whether of separately producing farmers or of workers who collectively manage a single farm, can provide producers with the democratic agency and protections they need. One relevant model of a regional economy is the Emilian Model mentioned in chapter two. This system that permits small farmers organized in cooperatives to produce many of Italy's food products could be replicated in other parts of the world, with assistance from the global cooperative and Fair Trade movements. It's worth quoting some of Restakis's speculations on this score:

The global co-operative movement contains within itself the material resources to do what the fair trade movement alone cannot do. Credit is one example. The credit unions of both rich and poor nations have the capital to establish a Fair Trade and Development Bank to do what the World bank and the IMF will never do-give direct support to farmer organizations, NGOs, business groups and local communities to build regional economies based on democratic control and ownership. An international cooperative development bank with members and progressive stakeholders from among consumers in the North and small producers in the South could provide the credit necessary to 
fuel the kind of value-added development that is now beginning to emerge in these areas. Among its top priorities would be to build up local credit unions that can play a regional role in this development process. This has already begun. The World Council of Credit Unions (WCCU) and the national co-operative federations of many countries have been working to build the development infrastructure of Southern regions for many years... ${ }^{304}$

What the future holds for global trade is anyone's guess, but it isn't impossible to imagine a new regime that gives a much more prominent place to Fair Trade organizations, regulatory structures that protect small farmers, and regional coordination of development among cooperatives and local governments.

Turning to the North, in particular the U.S., recent research has illuminated potentially revolutionary developments of a different character than those we have been discussing. Gar Alperovitz is the scholar who has done the most work on this subject, and his books America Beyond Capitalism (2006) and What Then Must We Do? Straight Talk about the Next American Revolution (2013) are essential reading. Alperovitz is not alone, however: a veritable industry of reportage and scholarship is growing to document the systemic alternatives that are emerging throughout the North. As these alternatives become more widely known, one can expect them to continue spreading on an almost exponential scale, as people clamor for change.

One example that Alperovitz discusses is "municipal enterprise," effectively a kind of small-scale socialism whereby local government owns and operates properties and businesses. As the website Community-Wealth.org reports, "Increasingly, local governments have turned to municipal enterprise to both raise revenue and promote local jobs and economic stability by developing a more

${ }^{304}$ John Restakis, Humanizing the Economy: Co-operatives in the Age of Capital (British Columbia: New Society Publishers, 2010), 186, 187. 
diversified base of locally controlled wealth. ${ }^{, 305}$ For instance, there are over two thousand publicly owned electric utilities in the U.S., which, together with a number of co-ops, collectively supply 25 percent of U.S. electricity - more efficiently and at lower cost to the consumer than private utilities do. Hundreds of cities have built public internet networks too, and hundreds more are building them now. ${ }^{306}$ Many other cities are involved in hotel construction and ownership, hospital ownership, transit development projects, ownership of land that is leased to companies for a profit, and environmentally friendly businesses like methane-recovery.

Important initiatives are in the works on the state level as well, most notably, perhaps, proposals to establish public state banks. North Dakota is the only state that has such a bank; it has been in operation since 1919. Its public bank is one reason why North Dakota is the only state to have been in continuous budget surplus since 2008. As Ellen Brown notes, "The bank has contributed over $\$ 300$ million in revenues over the last decade to state coffers, a substantial sum for a state with a population less than one-tenth the size of Los Angeles County." ${ }^{\prime 307}$ Public banks allow governments to invest in local communities, in ways that actually benefit the community rather than some distant corporate elite. Accordingly, a public banking movement is growing; as of 2013, at least twenty states were considering establishing a state-owned bank. ${ }^{308}$ Counties and municipalities are likewise beginning to consider proposals for public banks.

305 "Overview: Municipal Enterprise," http://www.communitywealth.org/strategies/panel/municipal/index.html (accessed June 24, 2013).

${ }^{306}$ Gar Alperovitz, What Then Must We Do? Straight Talk about the Next American Revolution (White River Junction, Vermont: Chelsea Green Publishing, 2013), 58, 60.

${ }^{307}$ Ellen Brown, "Banking for California's Future," Yes! Magazine, September 14, 2011.

308 Public Banking Institute, "Banking in the Public Interest," http://publicbankinginstitute.org/ (accessed June 24, 2013). 
Another type of institution with great potential is the benefit corporation (B Corp), which is a new legal form created in 2010. This kind of corporation differs from others in that "the goal is both to make profits and to use some part of them for social purposes.",309 Shareholders can't sue these businesses for failing to prioritize profits above all else, as they can in the case of a conventional corporation. The depth of public support for B Corps, and in general for a new, more socially conscious way of conducting economic activity, is shown by the fact that as of 2013, sixteen states had passed laws for benefit corporations. The number in early 2010, again, was zero.

More common than B Corps-because older-are community development corporations (CDCs), community development financial institutions (CDFIs), and community land trusts. CDCs are

nonprofit organizations dedicated to bringing about the revitalization of a clearly defined geographic area - often an urban neighborhood scarred by decades of disinvestment and concentrated poverty or an isolated and underdeveloped rural area. Governed by boards of directors composed primarily of local residents and other citizens with a strong stake in the community, most CDCs engage in some form of economic development within their service areas. ${ }^{310}$

They have been most successful at housing development, but in recent years have tried to return to the vision of their original founders (in the 1960s) and engage in "comprehensive economic, social, and political development activities," including communityowned and -controlled business development and economic revitalization. By 2005, 4600 CDCs had created over 1,252,000 units

\footnotetext{
${ }^{309}$ Alperovitz, What Then Must We Do?, 39. See Jamie Raskin, "The Rise of Benefit Corporations," The Nation, June 27, 2011.

${ }^{310}$ Thad Williamson, David Imbroscio, and Gar Alperovitz, Making a Place for Community: Local Democracy in a Global Era (New York: Routledge, 2002), 213.
} 
of affordable housing and generated 774,000 jobs. ${ }^{311}$ They rely for funding on nonprofits, foundations, corporations, and all levels of government. CDFIs, similarly, are institutions that give credit to communities shunned by traditional lenders; they include community development banks, community development credit unions, microcredit programs, etc. Community land trusts, on the other hand, of which there are several hundred in the U.S., are nonprofit corporations that hold and lease land to keep it affordable for the community by removing it from the sphere of the market. The National Community Land Trust Network states that the purposes of these nonprofits are "to provide access to land and housing to people who are otherwise denied access; to increase long-term community control of neighborhood resources; to empower residents through involvement and participation in the organization; and to preserve the affordability of housing permanently." 312 What their long-term potential may be is still not clear, but if sufficient public pressure is broad to bear on government, they could easily become of more than marginal significance.

The same is true of the more experimental and radical movement to establish "Transition Towns" around the world, where initiatives exist to "rebuild local agriculture and food production, localiz[e] energy production, rethink healthcare, rediscover local building materials in the context of zero energy building, [and] rethink how we manage waste." 313 As Richard Heinberg characterizes it, "the 'transition' that's being referred to is away from our current growth-

311 Joyce Madell, "CDCs and the Myth of the Organizing-Development Dialectic," Madison, WI: COMM-ORG: The On-Line Conference on Community Organizing, Vol. 15, 2009.

${ }^{312}$ National Community Land Trust Network, "What Are Community Land Trusts?," http://www.cltnetwork.org/About-CLTs/What-Are-CommunityLand-Trusts (accessed June 26, 2013). See also John Emmeus Davis, ed., The Community Land Trust Reader (Cambridge, MA: Lincoln Institute of Land Policy, 2010).

${ }^{313}$ Richard Heinberg, The End of Growth: Adapting to Our New Economic Reality (Canada: New Society Publishers, 2011), 271. 
based, fossil-fueled economy and toward a future economy that is not only sustainable but also fulfilling and interesting for all concerned." ${ }^{314}$ The movement began in 2005 in Totnes, England, and has spread to well over a thousand towns in at least 43 countries, all of which have initiatives inspired by the belief that "communities must become more resilient in the face of three catastrophic threats: peak oil, global warming and economic instability." 315 These initiatives include such projects as community gardens, communityowned energy production, community-owned bakeries and breweries, local currencies, and programs to incubate sustainable businesses. One celebrated initiative is called Transition Streets, which, in Totnes, "brought residents together, block by block, to support each other in decreasing their home energy use through improvements like insulation and solar panels. On average, each of the 550 participating households cut its annual carbon use by 1.3 tons and its annual energy bill by $£ 570$ (about \$883)." 316 Such projects admittedly seem too tiny to make much of a difference, but this may change as they become more common and publicized. The vision of "localization" that is behind them is likely to be ever more appealing, indeed necessary for survival, as the capitalist status quo disintegrates in the next century.

Turning to politics, a radical reform called participatory budgeting is gaining momentum around the world. First developed in Porto Alegre, Brazil in 1988, when the Workers' Party was elected, it has spread to over 1500 cities on all inhabited continents. ${ }^{317}$ Erik Olin Wright describes its functioning in Porto Alegre as follows:

\footnotetext{
${ }^{314}$ Ibid., 270.

315 Jessica Stites, "How the Transition Movement Is Spreading to Towns Across America," AlterNet, June 11, 2013, http://www.alternet.org. ${ }^{316}$ Ibid.
}

317 Participatory Budgeting Project, "Where Has It Worked?," http://www.participatorybudgeting.org/about-participatorybudgeting/where-has-it-worked/ (accessed November 26, 2013). 
Without going into details, the basic idea [of municipal participatory budgeting] is that citizens meet in popular assemblies throughout the city to deliberate about how the city budget should be spent. Most of these assemblies are organized around geographical regions of the city; a few are organized around themes with a city-wide scope-like public transportation or culture. At the beginning of the budget cycle each year these assemblies meet in plenary sessions. City executives, administrators, representatives of community entities such as neighborhood associations, youth and sports clubs, and any interested inhabitant of the city attends these assemblies, but only residents of the region can vote in the regional assembly. Any city resident participating in a thematic assembly can vote in those. These assemblies are jointly coordinated by members of municipal government and by community delegates. ${ }^{318}$

In Porto Alegre, participatory budgeting has consistently had high levels of participation and generated positive results. One resident observed in 2002 that before participatory budgeting, "there was no sewer, school, health clinic, or transportation. Now, a reservoir has been built with 6 million liters of water, the streets have been paved, and a school opened." ${ }^{319}$ In fact, as reported by the World Bank, "Sewer and water connections in the city...went up from 75 percent of total households in 1988 to 98 percent in 1997. The number of schools has quadrupled since 1986. Porto Alegre's health and education budget increased from 13 percent in 1985 to almost 40 percent in 1996." 320 There has been a "massive shift in spending toward the poorest regions of the city," corruption has been dramatically reduced due to transparency, and a "thickening" of civil society has occurred, with civic groups of all kinds being stimulated

\footnotetext{
${ }^{318}$ Wright, Envisioning Real Utopias, 110.

${ }^{319}$ David Lewitt, "Porto Alegre's Budget Of, By, and For the People," Yes! Magazine, December 31, 2002.

${ }^{320}$ World Bank, "Participatory Budgeting in Brazil."
} 
by issues of democratic budgeting. ${ }^{321}$ In the 2000 s, participatory budgeting began to spread at an accelerated pace, finally reaching the United States in 2010 (in Chicago). The remarkable successes it has had here and elsewhere are showcased on the Participatory Budgeting Project's website, participatorybudgeting.org.

The point, again, is that democracy, cooperation, and transparency are not only ethically imperative but more socially efficacious than the top-down, corporatized, bureaucratic, secretive methods of the contemporary ancien régime. When ordinary people have a democratic say in budget allocation, the money goes where it's needed most, not where it will benefit only some politically connected corporate interests. Schools are built, streets repaired, libraries expanded, facilities improved. Poor neighborhoods see more money, and can expect greater accountability, than they would otherwise. At the same time, involvement in the political process creates a better informed and more active citizenry, empowering people to form associations and networks through which they demand ever greater expansions of democracy from political officials. Participatory democracy reinforces and expands itself, so to speak. It counteracts social atomization, builds community, militates against apathy, and captures resources for people who will use them to further improve democracy.

Measures of even greater democratic significance have been enacted in Kerala, India. When Kerala's Left Democratic Front coalition came to power in 1996 it began a program of administrative, fiscal, and political decentralization to 1214 local governments. This ambitious campaign took advantage of the 1993 Constitutional mandates to increase local government power as a response to India's developmental failures and crisis of democracy. ${ }^{322}$ A brief summary gives some sense of the project's scale:

${ }^{321}$ Wright, Envisioning Real Utopias, 111.

322 T. M. Thomas Isaac and Patrick Heller, "Democracy and Development: Decentralized Planning in Kerala," in Deepening Democracy: Institutional 
The nested design of the Campaign's core institutionsGrama Sabhas (ward-level assemblies), development seminars, task forces, and local governments - represents a deliberate attempt to broaden avenues for citizen participation. In every year since 1997, local governments in Kerala have formulated and implemented their own development plans. These plans take shape through a multistage process of iterated deliberation between elected representatives, local and higher-level government officials, civil society experts and activists, and ordinary citizens. The process begins in open local assemblies, called grama sabhas, in which participants discuss and identify development priorities. Development seminars formed by the grama sabhas are then tasked with developing more elaborate assessments of local problems and needs. The development seminars give way to multi-stakeholder task forces that design specific projects for various development sectors. These projects are in turn submitted to local elected bodies (municipal councils called panchayats) that formulate and set budgets for local plans. Final plans are presented back to grama sabhas for discussion. These local plans are then integrated into higher-level plans (blocks and districts) during which all projects are vetted for technical and fiscal viability. $^{323}$

The logistics are very complex, but the campaign seems to have been successful both at invigorating democracy - it is extremely popular-and at implementing development more effectively than before. This is partly because "popular involvement increases problem-solving efficiency through better and more rapid feedback and increases accountability by multiplying the points of scrutiny." 324

Innovations in Empowered Participatory Governance, eds. Erik Olin Wright and Archon Fung (New York: Verso, 2003), 78.

${ }^{323}$ Ibid., 79.

${ }^{324}$ Ibid., 96. 
Much greater priority has been given to basic needs like sanitation, housing and drinking water than in the past, and there are now significant interregional differences as opposed to the "one-size-fitsall logic of the past." Just between 1997 and 1999, 98,494 houses were built, 240,307 sanitary latrines constructed, 50,162 wells dug, 8000 kilometers of roads built, and 2,800,179 people received support for seedlings and fertilizers - all of which far exceeds achievements from earlier comparable periods. ${ }^{325}$ At the same time, corruption has declined significantly, as happened, too, when the cooperative KDB was formed. ${ }^{326}$

The innovations in Kerala demonstrate the possibility of a politics different from the anti-democratic paradigm of the present. As an alternative economy develops, a Kerala-style politics may follow in its wake.

All these quasi-experimental "radical reforms," involving millions of people and thousands of institutions across the world, cannot be a mere historical curiosity. They have epochal potential. One participant contrasts them with the dreams of the old anarchists and socialists who looked forward to a cooperative commonwealth: "The old cooperativism," he says, "was a utopia in search of its practice, and the new cooperativism is a practice in search of its utopia." ${ }^{27}$ The contrast is apt. The tragedy of the old cooperativism, from a Marxist perspective, is that consciousness outran material conditions, material possibilities, and so it was doomed to failure; the new cooperativism has placed consciousness at the service of people's immediate economic interests, so that new modes of production and of governance are evolving step by step. Utopian dreams are being subordinated to economic realities - thus, perhaps,

\footnotetext{
${ }^{325}$ Ibid., 100.

${ }^{326}$ N. Ramakantan, "Democratic Decentralization and Empowerment of Local Government Associations in Kerala," Commonwealth Journal of Local Governance, vol. 2 (January, 2009): 128-136.

${ }^{327}$ Quoted in Ethan Miller, "Other Economies Are Possible!"
} 
making possible the realization of "utopian dreams" in the distant future.

The obvious question, though, is the one that has been posed to radicals from time immemorial: how will the old world succumb to the new? How is that possible? What will the process look like? At this moment in history, characterized by a convergence of crises, it is easier to imagine catastrophe than a new and more stable civilization. We're traveling headlong into a perfect storm of crises. For example, the UN projects that the world population will be almost ten billion by 2050 , which of course will put severe strain on human and natural resources. ${ }^{328}$ At the same time, global warming is expected to have an incalculably destructive impact on civilization and the global ecosystem: ocean levels could rise three feet or more by the end of the century; temperatures will rise at least 2.7 degrees Fahrenheit, probably much more; extreme heat waves will contribute to difficulty growing food and to massive changes in plant and animal life. ${ }^{329}$ In addition, the sword of Damocles hangs over humankind in the form of possible nuclear war, whether provoked by state or by non-state actors. And then there's the economic crisis I've already discussed. These circumstances in themselves are enough to show that there will be no smooth or peaceful transition to a more equitable and just society.

Some commentators, such as Chris Hedges and Richard Heinberg, insist that we are headed for a near-apocalyptic scenario. "The steady depletion of natural resources," Hedges writes, "especially fossil fuels, along with the accelerated pace of climate change, will combine with crippling levels of personal and national

${ }^{328}$ United Nations, Department of Economic and Social Affairs, Population Division (2013), World Population Prospects: The 2012 Revision, Highlights and Advance Tables (Working Paper No. ESA/P/WP.228).

${ }^{329}$ Justin Gillis, "Climate Panel Cites Near Certainty on Warming," New York Times, August 19, 2013; Joan Vidal, "Millions face starvation as world warms, say scientists," The Observer, April 13, 2013; Dahr Jamail, "Are We Falling Off the Climate Precipice?," TomDispatch.com, http://www.tomdispatch.com/blog/175785/ (accessed December 17, 2013). 
debt to thrust us into a global depression that will dwarf any in the history of capitalism." Heinberg speculates that soon our economic system will "implode":

And when it does the financial system will seize up far more dramatically than in 2008. You will go to the bank or the ATM and there will be no money. Food will be scarce and expensive. Unemployment will be rampant. And government services will break down. Living standards will plummet. "Austerity" programs will become more draconian. Economic inequality will widen to create massive gaps between a tiny, oligarchic global elite and the masses. The collapse will also inevitably trigger the kind of instability and unrest, including riots, that we have seen in countries such as Greece... ${ }^{330}$

These dire prophecies may be accurate, or they may be wildly exaggerated. What should be uncontroversial is that multifaceted crisis is here to stay for a very long time. It's predictable what popular reactions to it will be: demonstrations, periodic rioting, looting (in the case of natural disasters, as after Hurricane Katrina), perhaps a rise in crime, and grassroots organizing on both the political left and the right. What will determine how it all plays out is the reaction of the ruling class, which possesses most of society's resources and so has disproportionate power over the directions in which history proceeds.

Above I made some rather vague predictions regarding the behavior of governments and the ruling class, which I will qualify and elaborate on now. Of course it's impossible to predict the longterm future with any certainty. For all we know, nuclear war will destroy much of the species in the next century, or the collapse of

${ }^{330}$ Quoted in Chris Hedges, "Globalized Growth Is the Problem, Localism Is the Solution," Truthout, Monday, September 10, 2012, http://truthout.org/news/item/11435-globalized-growth-is-the-problem-localism-is-thesolution (accessed November 15, 2013). 
our current world system will lead to two hundred years of wars over natural resources. Nevertheless, I think it can be useful and interesting to speculate on possible paths that the future will takeand not only because I consider apocalyptic scenarios to be implausible. Assuming that human society doesn't revert to some kind of Hobbesian state of nature, one can sketch plausible paths of historical development and use those sketches to help guide strategy.

As I said above, the point to keep in mind is that governments and ruling classes are not monolithic entities. This fact is what makes possible a paradigm of revolution different from the orthodox Marxist one: rather than the working class suddenly rising up as one in a titanic social explosion, bursting through the straitjacket of a unified ruling class that has refused to reform capitalism, what can and should happen - and has happened in the past - is that popular struggles exploit divisions in the ranks of the elite so as to achieve gradual progress. Many wealthy people and institutions are reactionary, but many are progressive. In order to accomplish lasting, democratic change, it is necessary for popular movements to get some of the progressive elite at least partly and provisionally on their side. Universities, nonprofits, philanthropic foundations, liberal millionaires and billionaires, progressive businesses, and politicians are just some of the entities whose wealth and influence can be critical to the success of a movement or a new idea. By any means necessary, one must get their support-because if it isn't forthcoming, the combined might of the reactionary and the liberal elite will squash the left.

Fortunately, the last 150 years of Western history have taught us that when crisis afflicts society, much of the liberal elite is willing to favor measures that benefit the populace and are not dictated solely by the short-term interest of the capitalist class (or some narrow section of it). There exist wealthy benefactors of environmentalism, public education, civil liberties, the labor movement, infrastructure development, and the social and solidarity economy. As the reign of neoliberalism deepens the crises that beset the world, more and more entities in the ruling class will divert more and more resources to assuaging popular discontent, in many cases by funding radical new 
initiatives such as have been surveyed in this chapter. The rot that runs through traditional government and civil society makes this "experimentalism" utterly predictable_-because "desperate times call for desperate measures," etc. It's highly doubtful that social crisis will abate, so radical reforms, insofar as they are demanded by the masses and seem to work, will spread from region to region and country to country, as they are already doing.

It's instructive to contrast, again, the present situation with that eighty or a hundred years ago. Aside from the comparatively serious and multifaceted nature of contemporary crises, there are crucial differences between the periods that should hearten present-day radicals. Certainly the national and international left does not appear to be in good shape at the moment. On the other hand, a closer look reveals glimmers of hope. First of all, popular movements potentially have far more resources available to them now than in the 1930s or before. Technology is infinitely more advanced than it was, making possible global resistance movements and more effective coordination between them. Electronic media make it easier to publicize, on a wider scale, projects in an alternative economy and politics. Society is awash in wealth and knowledge, which, although it's concentrated at the top now, could be harnessed and used for the benefit of "the 99 percent" and their dissent. Many of the people who will be in dire economic straits in the coming decades are highly educated, college graduates, articulate and aware, who were raised with high expectations and are likely to be radicalized relatively easily. Moreover, their education and former position in the middle class will probably ensure that their protest is less ineffectual than those of some more marginal group might be.

From one perspective, the fragmentation of the contemporary left isn't even a bad thing. For it arises, in part, from the fragmentation of society itself, the dissolution of an integral capitalist civil society and the nation-state. A decaying social fabric - and a decaying national state - signifies, in the long run, a decaying corporate capitalism, a doomed civilization. It was different in the Great Depression, though: then, it was clear very quickly to far-seeing liberals that what was necessary to save capitalism was a 
stronger state, more state intervention in the economy, and stronger labor unions to bargain for high wages and so keep demand high and the economy running. With the strengthening of the state and unions would come a repairing of the social fabric and, in fact, the heyday of the nation-state system. Now, eighty years later, no one has a clear idea of how to save society (neoliberal globalization having made Keynesian nationalism impracticable) — which, in a sense, is a good thing for radicals, because it suggests that we really are nearing the end of the capitalist epoch. Systems and institutions are floundering; the left, for now, is floundering, as is the center, as is (in some cases) the right. But all this floundering opens up space for "decentralized" innovation, grassroots experimentation, localism and regionalism, under-the-radar moves toward cooperativism. This slow, semiinterstitial process is the natural way in which social (economic) systems yield to their successors.

Another respect in which the present has promise is that its transnational framework militates against fascism. Whatever revolutionary potential the 1930s had was vitiated by the (inevitable) consolidation of state capitalism, which in this early phase was easily susceptible to fascism, or "palingenetic ultra-nationalism." ${ }^{331}$ Fascist movements marched all over Europe in the 1930s, and in some cases they achieved total or partial control of the state. After all, they were useful to certain sections of the ruling class in their struggle to beat back the labor movement, Socialists, and Communists. At present, the same goal exists among similar reactionary entities of beating back the labor movement and progressivism of whatever form, and some of these entities are even willing to bankroll semi-fascist movements for this purpose. The Koch brothers' funding of the Tea Party is a well-known example. It's also true that as the middle class declines, one can expect many of the aggrieved to have sympathy with right-wing groups like Golden Dawn in Greece and the Tea Party in the U.S. This fact presents clear dangers for the left.

${ }^{331}$ That's Roger Griffin's definition, quoted in Stanley Payne, A History of Fascism, 1914-1945 (Madison, Wisconsin: University of Wisconsin Press, 1995), 5. 
Nevertheless, the dangers are surely not what they were in the 1930s. The point, again, is that the world is simply too interconnected now, and transnational corporations have too much power, for a return to the era of sovereign and autonomous nations to occur. In the thirties it was much easier to assemble the political apparatus of reactionary ultra-nationalism than it is in an age of advanced globalization, unparalleled access to information from global sources, widespread higher education, and greater political sophistication among the elite than when they allowed fascist leaders to come to power in the early twentieth century. Nor should we discount the lessons that people and institutions have learned from the experiences with Italian Fascism and German Nazism. Historical memory is not always acute, but in this case its power is not insignificant. The main threat that semi-fascist movements might pose is just that they will slow down progress - or in some instances reverse it temporarily-and exacerbate social problems. The possibility is minimal that they will decisively take over national governments and start World War III. Worldwide, there is every reason to expect that far more people will join progressive movements than fascist ones.

As for the much-discussed decline of the middle class, there are silver linings in this (insofar as it is happening). One would be a fool to deny that it's causing untold human suffering and is a fundamental manifestation, even a cause, of the horrors that are wrecking society. ${ }^{332}$ A Marxian, "dialectical" standpoint, however, which sees the good in the bad and vice versa, can complicate the narrative of unmitigated catastrophe. For the "middle class"-by no means a monolithic entity-has tended to be the bastion of centrist conservatism, the ballast that has steadied the course of capitalism (or, frequently, turned it to the right). No transition to post-capitalism could have occurred as long as the middle class was stable and intact, because few people whose material circumstances are satisfactory

${ }^{332}$ Robert Reich often writes thoughtfully about the decline of the middle class on his blog, http://robertreich.org/-as in his January 18, 2014 post, "David Brooks' Utter Ignorance About Inequality." 
would ever give that up to fight for the mere hope, and the very risky prospect, of a completely different social system. ${ }^{333}$ That is to say, as long as traditional labor unionism was strong, thus keeping the middle class strong, revolutionary hopes were doomed. Unions and collective bargaining had to decline - as did the welfare state-in order for radical possibilities to open up. This is an unpleasant and ironic truth that many leftists prefer to deny, but it is true. As I argued above, a post-capitalist order never could have happened within the corporatist framework of the nation-state; and industrial unionism and the welfare state were essential components of the mature Western nation-state. So they had to go. (And they were bound to go sooner or later, given capital's aggressiveness and its increasing mobility on a global scale.) In any case, capitalism cannot end except in the context of economic crisis, as Marx sensibly argued. And crisis on the scale necessary is incompatible with the existence of a large and protected middle class. So the decline of this "class," while presenting dangers in the form of semi-fascism, is a necessary prerequisite to a transition out of capitalism. ${ }^{334}$

The old question remains: is such a transition "inevitable," as many Marxists have thought? Is corporate capitalism necessarily going to succumb to its own contradictions and to the crises, and

${ }_{334}^{333}$ Erik Olin Wright makes this argument in Envisioning Real Utopias.

334 Marx had intellectual integrity, so he wasn't afraid to embrace unattractive but correct implications of his thought. During and after the 1850s he looked forward to economic crisis and was quite happy when it arrived, because he recognized that it fostered the conditions for revolutionary movements. (See Jonathan Sperber, Karl Marx: A NineteenthCentury Life (New York: Liveright, 2013).) Nowadays, many self-styled Marxists, such as the editors of Jacobin, who lack Marx's hard-headed realism and appreciation of history's "dialectical irony" think that twentieth-century social democracy could potentially have led straight into socialism if only things had gone differently, and that some sort of resurrection of the welfare state can still lead to such an outcome. See, e.g., Peter Frase and Bhaskar Sunkara, "The Welfare State of America," In These Times, October 22, 2013. I'll consider these fantasies again in the final chapter. 
resistance, it engenders? On this question, too, I'm an optimist, as I indicated above. For one thing, no social system is permanent; everything in history is transitory and in flux. More substantively, I agree with István Mészáros: "The fraudulence and domination of capital and the exploitation of the working class cannot go on forever. The producers cannot be kept constantly and forever under control." ${ }^{335}$ Indeed, the inevitability of the current social order's demise seems so obvious to me that I can scarcely argue for it. The facts speak for themselves. No civilization can possibly weather the crises that are in their infancy now - the chaos of climate change, overpopulation, economic stagnation, class polarization, government retrenchment, privatization and exhaustion of resources, commodification of everything, and possible nuclear war. Radical reforms are inevitable.

One way the future may play out is that such reforms, eventually supported by much of the elite, continue to spread for many decades as social instability increases. They build up a constituency that acquires a vested interest in their maintenance and expansion. Since national governments and bureaucracies are simultaneously becoming ever more dysfunctional and inadequate to the task of ensuring social order, the "reforms" typically amount to a partial ceding of powers to the regional, local, and international scales. Military and police repression of far-left movements continues in many places, and such movements or parties are rarely permitted to capture national governments (because they're too important), but on less visible scales, such as the local and regional, "the people" do have more and more say in governance-because the elite finds it necessary to make some concessions, and it's less dangerous to do so on lower levels of governance than on higher levels. Nevertheless, even on the national level one can predict that the left makes slow progress - simply because the right can't control things forever, otherwise society would completely collapse. The left's increasing

${ }^{335}$ István Mészáros, The Structural Crisis of Capital (New York: Monthly Review Press, 2010), 170. 
success is partly a result, too, of the fact that the ranks of the hyperelite are thinning due to the repeated bursting of economic bubbles, the protraction of economic crisis, and the consequent colossal destruction of wealth.

As the centers of global capitalism become more preoccupied with internal problems while having fewer resources to devote to policing world politics on behalf of corporate interests, left-wing movements in the global South have greater success against their governments. Quite possibly, democratic initiatives such as have been pursued in Kerala, India become more common, as do participatory budgeting, public banking, and comparable experiments. This gives more resources to the left, which therefore grows. Social and physical infrastructure continues to decay in places where the right still has control and improves where the left does-but, because the left is growing, the long-term trends are largely positive. Environmental deterioration and economic stagnation counteract these trends, but in many regions governments are able to alleviate the effects of these negative forces by, for instance, sponsoring programs to establish worker cooperatives and coordinating the distribution of resources to where they're needed most. Regarding the environment, the severity of the crisis and the clamoring of the people finally force governments around the world to take substantive measures against global warming and other forms of pollution-although for centuries to come, environmental disasters are frequent. Indeed, probably billions of people in the next century are severely affected by climate change and other such calamities, so that innumerable inter- and intra-governmental organizations are established to address these problems (by reforestation, promotion of renewable energy, distribution of water and food to devastated populations, and so forth). On local levels, governments tolerate and even encourage the proliferation of nonprofits, communal "crisis centers," large communal housing cooperatives and other "self-help" institutions, and grassroots endeavors we can't presently foresee to mitigate the impact of extreme weather patterns. The reason for this political support, again, 
is that such organizations promote social stability and are demanded by both the public and a large part of the elite.

In general, the only adequate way to respond to crisis is by pursuing measures that are the opposite of privatization and marketization. This fact alone should make a leftist optimistic with respect to the long run. As the world's corporate sector faces declining profit-rates from global overproduction and underconsumption, ${ }^{336}$ and even the financial industry is suffering from replays of the 2008 collapse (and other sources of instability), its resistance to progressive movements becomes less effective than it once was. More and more corporations succumb to bankruptcy. One can't rule out the possibility that some industries critical to societal well-being are nationalized. In any case, the point is that over generations, the character of the economy, society, and politics changes such that the "public sphere" expands, albeit typically in less centralized and nationalistic ways than in the mid-twentieth century. After a long evolution, new modes of producing and distributing resources have spread around the world, modes that we can't clearly foresee at present. What national governments will look like at this point is impossible to predict, except that they will probably be attenuated relative to the growth of other political forms. Certainly the principle of nationality itself will be hollowed out, since it will hardly serve any economic purposes any longer. ${ }^{337}$ The corporate capitalist class will have so thinned by this point that in many countries it will be possible for the "working class" (now in a

\footnotetext{
${ }^{336}$ See Brenner, The Economics of Global Turbulence.

337 This statement doesn't imply the crude economic reductionism one might think. Raymond Williams was right that in cultural and political analysis one has to take into account the "residues" of previous systems; for example, Christianity is a residue of the Middle Ages, though in modern times it has assumed new political and social functions that have time and again reinvigorated it. Likewise, the idea of nationality will persist for a very long time, even as economic and political transnationalism and localism make it ever more obsolete. See Raymond Williams, Marxism and Literature (New York: Oxford University Press, 1977).
} 
different form, much of it consisting of members of cooperatives and other democratic organizations) to effectively take over national governments and continue to transform them into mere extensions and enablers of lower-level and higher-level administrative apparatuses. Throughout this long history there will have occurred innumerable bloody clashes between armed enforcers of the status quo and proponents of democracy, but repression cannot work forever. Maybe 150 years from now, things will have started to settle down and the contours of the post-capitalist global order will be clear.

- That's one possible scenario, a relatively optimistic one. It doesn't seem wildly implausible, though. The premise underlying it is the commonsense truth that corporate capitalism and privatization are unsustainable, i.e., a democratic reaction against them is inevitable. Given this fact, the above scenario is one plausible account of the future. It does leave out such eventualities as nuclear war or the destruction of most of the human species by climate change, neither of which is out of the question. Another unpredictable variable is the politics of white rage, i.e., semi-fascism, which may be manipulated and co-opted by interests with a stake in imperialist rivalries, for example between the U.S. and China. ${ }^{338}$ Nonetheless, whatever scenario one concocts, it is surely inevitable that modes of economic, social, and political cooperation will evolve

${ }^{338}$ Recently the U.S. has been engaged in a "Pacific Pivot," "a major initiative announced late in 2011 to counter a rising China. According to separate statements by Secretary of State Hillary Clinton and Defense Secretary Leon Panetta, 60 percent of US military resources are swiftly shifting from Europe and the Middle East to the Asia-Pacific region." Koohan Paik and Jerry Mander, "On the Front Lines of a New Pacific War," The Nation, December 14, 2012. New military bases are being added to the hundreds that the U.S. already has on foreign soil in the Asia-Pacific, and the Trans-Pacific Partnership "free trade" agreement excludes China. Nikolai Bukharin's Imperialism and World Economy (1915) is worth reading in this context, being a classic analysis of the dynamics that still govern the world economy. 
to partially or totally replace the privatized competition that has led humanity to the brink of catastrophe. If most of the species is destroyed, for instance, democratic cooperation will probably be essential to the survival of the remaining humans. Certainly corporate capitalism will no longer exist.

It is largely futile to speculate on the future of the market or whether new forms of sophisticated barter or economic planning will emerge. What is certain is that, for all the reasons I gave above, no other model of revolution than the "gradualist" one I've sketched is relevant to a transition from capitalism to a more just society. Worker cooperatives may well be an important element in the accumulation of resources by leftists and "the people" that is necessary for the latter ultimately to achieve political power. The recognition among unions that a social movement unionism has become necessary will cause more to promote and form cooperatives, even as more workers follow the example of Argentinians after 2001 by taking over businesses in the wake of economic collapse and turning them into co-ops.

Incidentally, these happenings provide an opportunity for us to observe history's fascinating, albeit inhuman, symmetry and logic: while the wave of worker cooperatives in the late nineteenth century succumbed to an ascendant corporate capitalism, the wave that is just beginning now - a product of comparable conditions of inequality, economic "chaos," and insufficient government intervention in the economy - will continue to build as its nemesis corporate capitalism dies. Thus, cooperative movements sprang up in the fractured dawn, or pre-dawn, of an era in the 1870 s and 1880 s, and they spring up at its fractured dusk - only to enjoy a success they could not earlier when their nemesis was in its childhood rather than its old age (and when they themselves didn't have the resources they do now). Neoliberalism has thereby been an unwitting tool of the "cunning" of historical reason, by precipitating the demise of the very order whose consummation it was and making possible the rise of a new one.

New Era Windows, which I'll discuss in the following chapter, is one of the cooperatives in the vanguard of the coming revolution. It is still a rather lonely outpost overlooking a vista of economic 
desolation, but its loneliness will surely be a temporary condition. After decades of concessionary bargaining and passive rearguard action, the labor movement is finally, by virtue of the enormity of its predicament, being forced to embrace revolutionary strategies such as worker ownership. Herein lies the hope for the future. If current trends continue, in our lifetimes we may even see a recrudescence, in a more sophisticated global form, of the old heroic battles on behalf of cooperation against the robber barons, as the beauty of Catalonian socialism in 1936 - thousands of people joyously birthing a new world - emerges from behind the veil of memories into a world of possibility. 



\section{CHAPTER FIVE NEW ERA}

It may seem awkward to descend from the lofty heights of the previous chapter to the low terrain of a case-study, but it is precisely on the level of local institutions and their mutual self-help (with political assistance) that a new economy will have to develop. Its cooperative dimension will emerge in a variety of ways: people starting a co-op from scratch, buying out an employer, benefiting from liberal initiatives as in Cleveland, using their union to start a cooperative, etc. In the following I'll consider the second case, that of buying out an owner. In the U.S., since the late 1970s there have been countless attempts by workers to buy out employers that planned to shutter factories; few of these have been successful, typically because of capitalist resistance. For example, in 2010 a hundred employees at an aerospace plant in Taunton, Massachusetts that was about to be closed by their employer, Esterline Technologies, wanted to buy its equipment so as to run the plant themselves. After being rebuffed by the company, they and their union, the United Electrical Workers (UE), convinced the city of Taunton to pursue the use of eminent domain to seize Esterline's machinery and buy the factory on behalf of the workers. This was unprecedented in recent labor history, and the tactic holds promise for the future. Unfortunately, it didn't work in this case, for complex reasons we need not dwell on here. ${ }^{339}$

Despite past failures, one can expect that such attempts will continue, indeed will probably become more numerous as unions and the progressive elite embrace the idea of employee buyouts and/or using eminent domain to save jobs. The more success stories are publicized, the more attractive these options will be (and the easier it

${ }^{339}$ Roger Bybee, "UE and Taunton, Mass. Chart Own Course in Fight Against Outsourcing," In These Times, December 14, 2010; Peter Ranis, "Occupy Wall Street: An Opening to Worker-Occupation of Factories and Enterprises in the U.S." 
will be for workers to find financial assistance). One such success story is that of New Era Windows, which bought its equipment from the former owner in 2012. This case is particularly interesting and instructive given the workforce's history of militancy, including factory occupations, and success in confrontations with employers.

For people who want to start a co-op from scratch, there are dozens of books and manuals, some of them available at www.american.coop and www.usworker.coop. University courses are now being offered as well, at UMass Amherst, Rutgers, the University of Connecticut, Southern New Hampshire University, MIT, and other places. ${ }^{340}$ It is probably more feasible, however, that large cooperatives are started by buyouts and takeovers than from scratch by entrepreneurs, so those scenarios are what I focus on in this chapter.

The New Era Windows cooperative is run by a workforce that, since 2008, has grown used to the glare of the media spotlight. In 2008 these workers symbolized the nation's disgust with the greedy and corrupt bankers who had run the economy into the ground and then gotten bailed out, and their defiance of the leviathan that is Bank of America was inspiring. Even Barack Obama, no leftist, felt compelled to express support for them: "I think they're absolutely right and understand that what's happening to them is reflective of what's happening across this economy." ${ }^{341}$ Six years later, they symbolize not only defiant action for workers' rights but defiant construction of an alternative to corporate capitalism. Coverage of their actions by the New York Times, the Washington Post, the Chicago Tribune, The Nation, Yes! Magazine, the major television networks, Democracy Now!, Al Jazeera, and innumerable other media outlets around the world testifies to how deeply their story resonates with the public. The obvious questions, then, are: what is

\footnotetext{
${ }^{340}$ American Worker Cooperative, "Curricula," http://american.coop.

${ }^{341}$ Monica Davey, "In Factory Sit-In, an Anger Spread Wide," New York Times, December 7, 2008.
} 
their story?; how have they accomplished all that they have?; and how can their victories be replicated?

Journalist Kari Lydersen published an excellent account in 2009 of the workers' struggle against Bank of America and Republic Windows and Doors, entitled Revolt on Goose Island: The Chicago Factory Takeover, and What It Says about the Economic Crisis. In the first part of what follows I'll draw disproportionately on her book, summarizing some of its main points in order to provide context for the discussion of the cooperative later.

Republic Windows and Doors was formed in 1965, and continued to grow until the end of the century. By the 1990s it was selling vinyl replacement windows and patio doors not only to small home-improvement contractors, as earlier, but to businesses, factories, and apartment complexes. It owned a large factory on Goose Island in Chicago where it employed hundreds of workers, primarily Latinos who had left Mexico and their families behind. This predominance of Latino workers is, of course, not an unusual thing in the "postindustrial" U.S. More than 50 million Latinos live in the United States, 23 million of whom are in the labor force (employed or unemployed). ${ }^{342}$ Millions of these people are recent immigrants who regularly send money back to their relatives at home or try to earn enough for their families to join them someday in the U.S.; for instance, three-quarters of the workers at Republic had emigrated from Mexico. ${ }^{343}$ In part because of the rising proportion of Hispanic immigrants, low-wage workers in the U.S. are increasingly likely to be Hispanic. ${ }^{344}$

\footnotetext{
${ }^{342}$ United States Census Bureau, "Most Children Younger Than Age 1 are Minorities, Census Bureau Reports," May 17, 2012, at www.census.gov; Labor Council for Latin American Advancement, Latino Workers in the United States, 2011 (Washington, D.C.: LCLAA, 2011).

${ }^{343}$ Kari Lydersen, Revolt on Goose Island (Brooklyn, NY: Melville House, 2009), 17.

${ }^{344}$ George J. Borjas, "Wage Trends among Disadvantaged Minorities," National Poverty Center, August 2005.
} 
Given these trends, it is not much of an exaggeration to say that "the future of America's labor movement will be written in Spanish." ${ }^{445}$ This fact should, perhaps, be encouraging to labor organizers, because, as the Republic occupation and other militant actions in recent decades suggest, there are clear tendencies for Latino and indigenous American workers to be more easily radicalized than white or even African-American workers. ${ }^{346}$ The latter groups have typically been socialized into the neoliberal American way of behaving and thinking, an unfortunate amalgam of atomism, loneliness, cynicism, interpersonal alienation, semi-passive resignation, disdain for unions, and so forth. Latino immigrants, by contrast, having come from a very different society with its own history and culture - in most cases a vibrantly left-wing or "populist" one at the grassroots - have not typically internalized American atomism in the way that the mainstream has. This is evident simply from impressionistic observation. Moreover, the very fact of constituting a minority in another country, speaking another language, being more cruelly oppressed than most mainstream groups, and to some extent possessing a common culture different from the dominant one, pushes people towards solidarity, mutualism, and militancy in social and political struggles. These are good omens for the future labor movement in the United States, especially considering that Hispanics are the largest and fastest-growing minority group.

Richard Gillman, who became the owner of Republic in 2005, thus had the bad luck of inheriting an intractable workforce. This was particularly the case because the workers had voted in 2004 to end their association with a union called the Central States Joint Board (CSJB) and affiliate with the UE, one of the most militant and progressive unions in the country. Disenchantment with the conservative, undemocratic, and corrupt CSJB had become acute in

345 Tom Buffenbarger, President of the International Association of Machinists and Aerospace Workers, quoted in Latino Workers in the United States, 6.

${ }^{346}$ See, for example, Leon Fink, The Maya of Morganton. 
2001, when the union negotiated a dismal contract with Republic. As Lydersen recounts, workers were so disgusted that they organized a wildcat strike a couple months later, in January 2002. For more than two weeks, in the freezing cold, they held out against the opposition of the company, the union, and the police, who all encouraged workers to cross the picket line (as some did each day). "On a particularly frigid morning," for example, "some workers were lured across the picket line by the quintessentially Chicago bait of Krispy Kreme doughnuts and coffee." ${ }^{347}$ Despite the support of Latino elected officials, including U.S. Congressman Luis Gutierrez, the strike failed and workers were forced to return to their jobs-while continuing to nourish the hope that someday they could get rid of their union.

Through informal contacts with labor-rights and immigrantrights groups in Chicago, the workers eventually met with UE organizers Leah Fried and Mark Meinster, who convinced them that theirs was a much more effective union than the CSJB. In late 2003, about a year before the CJSB's contract was going to expire, "the UE launched its typical organizing drive, holding meetings to inform workers of their rights, providing stickers and flyers, and pointing out all the things the CSJB was not doing for them." ${ }^{348}$ As is usually the case, a "militant minority" among the workers was crucial to the success of the organizing drive (and would prove crucial to the 2008 factory occupation). Armando Robles, for example, a maintenance worker in his late thirties who had started working at Republic in 2000, discussed with his coworkers week after week the merits of the UE, passing out flyers, holding meetings in community centers, and in general trying to counter the company's anti-union propaganda. When it came time for the election, the UE trounced the CSJB, 340 votes to 9. (About 100 workers voted for no union at all, having been disillusioned by their earlier one.)

\footnotetext{
${ }^{347}$ Lydersen, Revolt on Goose Island, 39.

348 Ibid., 41.
} 
Since the UE played a critical role in later years, it's worth saying a little about this unique union. It was formed in 1936, when independent local unions attended a conference in Buffalo, New York to create a national union that would organize the radio and electrical manufacturing industries. A few months later, it became the first union granted a charter by the newly formed CIO, which was a progressive alternative to the old, craft-union-based AFL. In the legendary years of the late 1930s when the United Autoworkers was organizing the automobile industry, the Steel Workers Organizing Committee was organizing the steel industry, and the Packinghouse Workers of America was organizing the meatpacking industry, the UE was making swift and fantastic gains at General Electric and other major corporations. Its victories continued through World War II, so that by 1945 it was the third largest CIO union, with over 500,000 members.

The organizational structure that made possible these early successes - as well as the union's later tenacious survival in difficult times - was unusual in the U.S. labor movement. The UE was and remains a much less centralized and bureaucratic union than others, with radical democracy enshrined in its constitution and by-laws. Union members not only elect, from among their ranks, local officers, stewards, negotiators, and delegates to national conventions; they also decide, themselves, when to strike and to end a strike, when to accept a contract and what terms to demand, and how to use local dues. The salaries of union staff and executives do not exceed the highest wage in the industry, a provision unique among American trade unions. On rights for women and African-Americans, the UE was far ahead of its time and most other unions, for example supporting "equal pay for equal work" during World War II and fighting to end workplace discrimination against blacks. It has also not been afraid to take controversial political stances such as opposing the Vietnam War (when the AFL-CIO resolutely supported 
it) and being actively involved in the civil rights movement. On the whole, it is hard to imagine a more progressive and militant union. ${ }^{349}$

In the context of the Cold War, however, progressivism was not unequivocally an asset. It led several unions, including the UE, to be branded as Communist and hounded out of the CIO. The 1950s were a dark time for the UE: under a barrage of attacks from business, the federal government, and mainstream unions, its membership plummeted to 60,000 . It's a miracle that it survived at all; virtually no other left-wing union did. In the 1960s it began to rebuild its numbers, but the deindustrialization of the 1980s and 1990s wiped out many gains. At present the UE has about 35,000 members, and even this relatively low number has only been made possible by the union's trademark radicalism and flexibility. It has branched out from its traditional industrial jurisdictions to include teachers, nurses, and clerical workers, and it was one of the first unions to embrace undocumented immigrants. It has also been at the forefront of efforts to build transnational alliances, having formed a close alliance with the Mexican union Frente Autentico del Trabajo in the 1990s when they were both fighting NAFTA. ${ }^{350}$

In the light of this honorable history, it should come as no surprise that the contract the UE negotiated with Republic in 2005 was excellent from the workers' point of view: "They obtained a nearly unheard-of average \$3-an-hour raise over the course of three years, with $\$ 1.75$ in the first year. They overhauled a subpar bonus system. And they won the right to have 19 union stewards on the shop floor, compared to five before. This meant more power for the union and more ability to file and win grievances." ${ }^{, 351}$ A couple years later, Armando Robles was elected president of the local-Local

\footnotetext{
${ }^{349}$ See Ronald Filippelli and Mark McColloch, Cold War in the Working Class: The Rise and Decline of the United Electrical Workers (Albany: State University of New York Press, 1995); Lydersen, 46-53; and the UE website, http://www.ueunion.org/.

350 Tamara Kay, NAFTA and the Politics of Labor Transnationalism, chapter five.

${ }^{351}$ Lydersen, Revolt on Goose Island, 42.
} 
1110 - and Ricky Maclin vice president, forming a partnership that would prove effective and long-lasting.

Being a democratic union, the UE gives leadership training to its members, particularly the stewards. This "consciousness-raising" and confidence-boosting is essential to giving members a sense of empowerment, efficacy, and self-respect vis-à-vis management. Leah Fried gives the example of training in grievance procedures. Stewards will learn about the different kinds of grievances, the steps involved in filing a grievance, and how to follow through in meetings with management. After reading through the contract and learning all the procedures, they then simulate a grievance meeting: one person plays the boss, another is the steward, a third the worker filing the grievance. Later, after a real grievance meeting, they meet to go over what went well and what to do differently next time, and so the learning process continues over months and years. Gradually the workers become more effective at standing up for their rights.

For instance, one time a Republic worker was fired for taking out the garbage. Literally: as Fried recalls, "he took out the garbage and the supervisor fired him, saying 'You weren't supposed to take out the garbage!' So we got everybody to wear a picture of [the worker who had been fired], and they marched into the boss's office during their break..." ${ }^{352}$ Combined with the filing of a grievance, this collective action got the worker rehired.

Horizons, in short, weren't very sunny for Republic on the labor side of things; but the business side wasn't doing much better. The situation became especially dire in 2007 , when the real estate boom collapsed. The loss of customers meant that Republic quickly used up its $\$ 5$ million line of credit from Bank of America, which refused to grant more loans. By the summer of 2008 the company had lost $\$ 10$ million in less than two years, and its factory was in the process of being downsized from 500 workers to 250 . November 2008 is when the real drama started.

${ }^{352}$ Author's interview with Leah Fried, January 22, 2014. 
Robles and other workers noticed that factory equipment was being spirited away in the night, to an unknown destination. Managers assured them and UE officials that nothing was amiss, an obvious lie given the business's economic troubles (of which workers were well aware). It was revealed later that the equipment was intended for a factory in Iowa that Richard Gillman planned to be the base of operations for a new, un-unionized, company; at the moment, all that the workers knew was that they couldn't sit idly by while their factory was dismantled, an action sure to presage the elimination of their jobs. As Lydersen relates, the workers organized surveillance teams to keep an eye on the factory during nights and weekends. One Saturday, Robles and Sergio Revuelta, a union steward, were fulfilling their watchman duties in the parking lot when they saw boxes being loaded onto two trailer trucks at the factory's front entrance. They decided to follow them, curious where they were headed. Fifteen miles later they ended up at a truckyard, where the trailers were parked. Robles called Mark Meinster, who drove out to them to discuss what they should do. Angry at Republic's brazen contempt for its workforce, Robles suggested stealing the trailers to force the company to negotiate with them. Or at least deflating their tires. Meinster hit upon another idea to save their jobs: stage a sit-in at the factory. Robles liked the suggestion, and in the following days he and Meinster found others enthusiastic as well.

So that's how the idea was born. Factory occupations are more common in Mexico and other parts of Latin America than in the United States, so it isn't surprising that a mostly Latino workforce would be attracted to the idea. The local's executive board certainly was; its members saw no other option in the case of the plant's closure. Many other workers were similarly enthusiastic, and it was easy to find volunteers to occupy the plant. No action was taken for the moment, except to organize 24-hour surveillance over the long Thanksgiving weekend, each shift lasting two hours.

The workers' strange "limbo" situation lasted until December 2, when the plant operations manager called them to a meeting in the cafeteria and announced, predictably, that the plant would be closing 
on Friday, December 5. They wouldn't get severance pay or accrued vacation pay, and their health insurance would end on December 15 (in fact earlier, as it turned out). This sudden closing of the plant was in apparent violation of the Worker Adjustment and Retraining Notification (WARN) Act, which requires that employees be given either sixty days' notice or sixty days of severance pay, a fact that would be exploited by workers and their allies in the following days, when they declared to the media that it was illegal to close the plant under these conditions. After bringing his grim tidings the manager hastily retreated, leaving everyone to contemplate the destruction of the lives they had known.

It's at this point that connections became especially important. Most things in the modern world depend on connections; luckily the Republic workers had them, through the UE. Union representatives got in touch with their contacts in the Chicago political world and such groups as Interfaith Worker Justice and Jobs with Justice; it was decided that the next day, December 3, there would be a protest rally in front of Bank of America's headquarters downtown. This was the strategy they had decided on: it made more sense to publicly shame Bank of America than Republic, in part because the latter had insisted that everything was the bank's fault for having cut off credit, and in part because the bank had just received a $\$ 25$ billion bailout from the government and was by no means popular with the public. This was, after all, the moment when Americans were enraged by the financial sector's sabotage of the economy and disgusted by the TARP bailouts of the chief culprits. Attacking Bank of America for destroying jobs even after accepting public funds was a brilliant strategy - which the media, for its part, was happy to facilitate, given the public's mood.

As Leah Fried explained later, the union and workers crafted their image in a very conscious and knowing way. The issue couldn't be worker rights, because, as she said, "the media doesn't cover worker rights. It's very rare that they will. In fact, some of them right up front said we can't cover a union story." So instead, the union framed it as a story of the bailout. "This is what the taxpayer bailout is really doing. It goes to these financial institutions who then turn 
around and shut down factories. People are losing their jobs, and on top of that, they're not even being paid the money that they earned." 353 This so effectively tapped into the public's rage that, in the end, the workers had much more success than they expected.

The rally on Wednesday gained visibility for the coming struggle, but of course it was the occupation that captured international headlines. On Friday morning Robles, Fried, Meinster, and other union leaders met with the full workforce to ask once more if they wanted to go ahead with their plan: everyone did. "Si se puede!" they cheered. "We can do it!" About thirty people said they would occupy the plant, while the others would support them outside on the picket line. (The action was illegal, after all, and some workers were worried about the repercussions for their families if they were arrested.) Later in the day, though, when a final vote was taken just before the action was to commence, everyone wanted to occupy, no doubt caught up in the thrill of what they were doing. They formed committees to organize it, deciding, for example, that three shifts would be set up so that people could periodically go home to get some sleep; in general, only workers, union staff, and family members would be allowed inside; and the place would be kept tidy for the sake of public image. Soon after the occupation had begun at 5 p.m., managers called the police to implore that the workers be forcibly removed; the police, however, refused, having been told earlier by the city councilman representing Goose Island that this was a labor-management dispute in which they shouldn't intervene.

This points to the importance, again, of having connections with progressive members of the elite. From the very beginning, Congressman Luis Gutierrez was an articulate defender of the workers, an intermediary (along with union reps and others) between them and Bank of America, and an effective coordinator of resources such as food. Other political figures who showed support in the

${ }^{353}$ Leah Fried, interview with Bob Bruno, Illinois Labor Works, Chicago Access Network TV, December 17, 2011. 
following days included the Illinois Attorney General, concerned whether Republic had broken laws in its treatment of workers; Governor Blagojevich, who visited the factory on Monday (three days after the occupation had begun) to declare his support for the workers; Obama, who on Sunday had done the same thing in a press conference; Jesse Jackson, who showed up at the factory to hand out turkeys and offer encouragement; U.S. Senator Dick Durbin, Congresswoman Jan Schakowsky, various city councilmen, and county commissioner Mike Quigley. All wanted to bask in the popularity of these workers who were seen as defying the monster that is Bank of America.

The press, including correspondents from national and foreign media, were already at the factory on Friday before workers emerged to announce that they were occupying it until their demands were met. The UE's contacts with the media and activist groups around the city thus paid off from the start. Republic officials hadn't shown up to a meeting on Friday with Bank of America and union leaders, so the sit-in continued into the weekend. A support rally on Saturday drew several hundred people, and donations of food, sleeping bags, pillows, and other items flooded the plant. Jobs with Justice continued to organize solidarity rallies nationwide in the following days. Inside the factory the atmosphere was in fact somewhat festive, despite people's fear of arrest. Initially, indeed, they expected to be arrested, and yet were determined not to leave. When several policemen ventured inside the plant on Friday night some of the occupiers prepared to chain themselves to the equipment, but were relieved to see that the police were only checking for vandalism. ${ }^{354}$ The lengths to which workers were prepared to go to defend their jobs is a poignant illustration of their outrage and desperation, shared by millions of others that winter.

Another meeting with Bank of America and Republic was called for Monday, but this one didn't go very well either, at least at first. Gutierrez and a couple city councilmen joined Robles, Maclin, and

${ }^{354}$ Author's interview with Armando Robles, January 8, 2014. 
union reps, all of whom faced a room of representatives from the bank, the Chamber of Commerce, the city treasurer's office, and other state agencies and interest groups. Maclin got angry when a Chamber of Commerce official asked the workers to tone down their statements to the media and stop making the bank look so bad; he slammed his fist down on the table, cursed loudly, and retorted that he'd tell the media whatever he wanted. Things went a little more smoothly later, but still no resolution was reached.

On Tuesday, after another day of the media "eating out of the workers' hands" ${ }^{355}$ - even Fox TV, no friend of labor, praised them-talks resumed, this time more fruitfully. Richard Gillman angered the labor side when he asked, incredibly, that any new loan from Bank of America (to pay workers' wages) include severance pay for himself and funds to pay the leases on his two luxury cars"even his own attorney looked at him like he was crazy," said Maclin later-but after a huddle with the negotiators he withdrew his request and agreed to pitch in $\$ 117,000$ of his own money to meet his exemployees' final payroll. The bank then agreed to extend a "loan"really a donation, since there was little chance it would be paid back - to cover the rest of the money owed the workers. The deal couldn't be finalized immediately, though, since UE officials, consistent with the union's democratic traditions, insisted that all the workers would have to vote on it later.

On Wednesday a final meeting occurred with Bank of America and JP Morgan Chase, which had 40 percent equity in Republic. Their proposal amounted to $\$ 1.35$ million from the former and $\$ 400,000$ from the latter to cover workers' severance and vacation pay, and two more months of health insurance. At the factory that evening the workers, thrilled at their victory, voted to accept the offer-and yet were disappointed that it appeared the plant wasn't going to be kept open. How would their families survive the next year? What kind of jobs could they get in this dismal economy? They decided right away to start a new trust fund, the "Window of

${ }^{355}$ Lydersen, 91. 
Opportunity Fund," to raise money to buy the plant themselves or find another buyer. In the meantime, they accepted their partial victory and celebrated with their supporters, both in the immediate community and, in spirit, all over the world.

What had made their victory possible, then, was an unusual confluence of factors. First, they were lucky enough to be represented by a union as militant and democratic as the UE. Leah Fried says it well:

Here's what made it possible for UE to do this [sit-in]. Number one, we had spent the time building the leadership in that local. The leadership had gained a lot of skill and knowledge. People had been through fights before... We had built relationships with other unions, with community groups, with the immigrant-rights movement, with important coalitions in the city like Jobs with Justice and Interfaith Worker Justice... We had built relationships over time, and we called on those relationships when the moment was right. And folks rallied, because they saw this as their fight, not just a UE fight. So, I think anybody could do it; you just gotta practice fighting, and you gotta build relationships with the rest of the movement. And start acting like a movement when the moment comes. ${ }^{356}$

If the labor movement as a whole acted more like the UE-or like the Chicago Teachers Union when it organized its internationally celebrated strike in September 2012-things might improve for workers. Unfortunately, the momentum and direction of entrenched bureaucracies, such as exist in mainstream trade unions, are not easily set on a new course. Timid, conservative, and establishment traditions cannot be reversed unless circumstances force them to be-that is, unless a context of prolonged crisis for the bureaucracies themselves finally necessitates their radical change.

${ }^{356}$ Leah Fried, interview with Bob Bruno. 
The labor movement seems to be undergoing this change now, at long last. It does have a ways to go before it catches up to the UE, though.

The very fact of having a union at all, or at least having a nearby worker center that can lend its support and resources, is virtually a prerequisite for the sort of action that Republic's employees undertook. Certainly if the action is to have some success, organizational resources - and the confidence that comes with them-are a necessity. This may help explain why the Republic occupation didn't cause many similar acts around the country. The unionization rate in the U.S.'s private sector is less than seven percent, which doesn't translate into a lot of organizational resources for workers.

Similar incidents did happen, though. The most notable was after the Colibri Group in Rhode Island, a jewelry maker, laid off its 280 employees (mostly immigrants) without giving advance notice; some actually arrived at work the day the plant closed only to see a sign informing them of the fact. And that was it, even for those who had worked there twenty or thirty years. "I gave them so much, my whole life," one worker said later, "and then they just closed the doors on us like we were animals. I felt like my heart was on the floor." ${ }^{357}$ Since no notice had been given, the employees were entitled (under the WARN Act) to sixty days of severance pay and health insurance. They had no union, but some of them got in touch with a local immigrant- and labor-rights group called Fuerza Laboral — which had just two staff members-and organized a protest rally a couple weeks later, on February 3, 2009. Three days later, coincidentally, Armando Robles and a few other Republic workers and UE representatives came to Providence on a tour they were taking around the country - called the Resistance and Recovery Tour - to spread word of their story and raise money for their trust fund mentioned above. The fifty Colibri workers they met with were inspired by what they heard, all the details of how a couple hundred

${ }^{357}$ Emilio Blanco, quoted in Lydersen, Revolt on Goose Island, 150. 
Latino workers had shamed Bank of America before the world. So they decided to enact a similar campaign to shame the majority owner of Colibri (Founders Equity) and two banks that were creditors. In the following months they and Fuerza Laboral took many actions, including marching on the state capitol, protesting in front of Founders' Manhattan headquarters, initiating a national letter-writing drive, and filing a lawsuit to get the money they were owed. But the act most reminiscent of the Republic sit-in happened at an auction of Colibri's assets on March 19: fourteen people, including ten workers, were arrested for sitting on the street to block traffic to the auction. ${ }^{358}$

While the campaign got attention from the media and sympathy from politicians, it didn't have the success of the Republic sit-in. The workers were never paid, because creditors got everything left over from the business. Why this failure? One obvious reason is that the factory had already been closed, so it couldn't be occupied. As Occupy Wall Street showed in 2011, occupying an area can be a uniquely effective tactic if it draws media attention and/or prevents members of the elite from using facilities valuable to them. It forces the authorities either to give in to protesters' demands or deploy the police to violently disperse them, which never makes the elite look good. Thus, none of the actions of the Colibri workers quite "packed the punch" of a factory sit-in. Nor did the workers have the resources of a battle-hardened union, powerful coalition partners, or ties to political leaders.

The Republic workers also benefited, of course, from perfect timing (although Colibri workers' timing wasn't much worse). It was soon after the TARP bailouts had been announced, jobs were hemorrhaging - awful employment numbers came out on the very day the sit-in began-and people worldwide were enraged at the corporate sector. Hopes for comparable or greater victories in the future should be raised by the knowledge that for a very long time to

${ }^{358}$ Lydersen, 148-154; "Police arrest protesters at E. Providence plant," Associated Press, March 19, 2009; Kelsey Abbruzzese, "RI workers suing jewelry maker for pay, benefits," Associated Press, May 21, 2009. 
come, economic stagnation and crisis will be the norm. Crises are bound to continue recurring, and as they do so the public will grow more angry at big business and more sympathetic toward factory occupations. While it won't always be possible for workers to invoke unpopular "bailouts," they will still be able to attack corporations for destroying jobs and not paying employees what they're owed-two compelling soundbites, as Bank of America learned to its cost. If unions and their allies have the will, the "way" will present itself.

I've spent so much time discussing the 2008 sit-in because I think this tactic is the most radical and effective of all, and I suspect it will grow more common in the next decade or two. As seen in hundreds of cases in Argentina after its 2001 crash, it can even lead straight into the formation of a worker cooperative. In the case of the Republic workers, the route was a little more circuitous. Let's consider that route briefly now, after which I'll discuss the co-op itself.

A company called Serious Materials (later Serious Energy), which manufactures energy-efficient building materials, bought Republic's factory in February 2009. With the help of Obama's 2009 stimulus package, it hoped to hire back all of Republic's former employees by the summer. Things didn't work out as planned, though: by September 2009, only twenty employees had been rehired, for reasons having to do with bureaucratic delays and insufficient stimulus funds. ${ }^{359}$ Over the next couple years, in fact, only about 75 workers were hired back. Then, on February 23, 2012, the UE was notified in a meeting with local executives that the plant would be closed that very day, because of "ongoing economic challenges in construction and building products, collapse in demand for window products, difficulty in obtaining favorable lease terms, high leasing and utility costs and taxes, and a range of other

${ }^{359}$ Kari Lydersen, "One Year Later: The Republic Windows Story," War Resisters League, Winter 2010, https://www.warresisters.org/content/oneyear-later-republic-windows-story (accessed December 20, 2013). 
factors." 360 This time, at least, management said it would pay workers what they were owed under the WARN Act; union officers and staff, however, wanted to find a buyer for the factory, so they could save the jobs. Management refused.

Because of a recent layoff, only 38 workers were employed at the moment. After the meeting with Serious, therefore, Robles and Fried called laid-off employees, asking them to come to the plant. Fifty workers met at 2 p.m., the end of the shift, to discuss the situation. Journalist Jane Slaughter describes what happened next:

Robles presented [their options] soberly: Do nothing, or fight - stay and occupy the plant again. Without much hullabaloo, matter-of-factly, the members voted unanimously to occupy.

They had no food, no sleeping bags. Workers and leaders immediately started to phone fellow workers, allies, and the media. They called the local alderman and asked others to alert the mayor's office. Occupy Chicago came with tacos. Stand Up Chicago arrived.

Workers from other UE locals, including recently organized railroad van drivers, were there. Republic workers who'd never been called back to Serious but who still came to union meetings were there. The crowd inside grew to 65 and outside to $100 .^{361}$

UE regional president Carl Rosen got in touch with Serious CEO Kevin Surace to tell him the workers were prepared to be dragged out and arrested. The police showed up after being summoned by management and warned the workers that in five minutes they would be arrested if they didn't leave the plant. And maybe they would have been, if not for the many supporters outside with cellphones

${ }^{360}$ Juan Conatz, "Workers occupy factory in Chicago," February 24, 2012, http://libcom.org/news/workers-occupy-factory-chicago-24022012.

${ }^{361}$ Jane Slaughter, "UE Occupies Chicago Window Plant Again, and Wins Reprieve," Labor Notes, February 24, 2012. 
and cameras, including local TV news cameras. So the police thought better of their threat and let the workers stay. By 5 p.m., Occupy Chicago was raising tents as workers inside played dominoes and ate donated food.

Soon, corporate headquarters in California took over negotiations, having decided they didn't want a big confrontation with the union. By 1 a.m. they had, incredibly, agreed to all their employees' demands: in addition to severance pay for all the workers - even the ex-employees of Republic whom Serious had promised to hire but never had-the plant would stay open for ninety days, giving time for the workers and their union either to find a new buyer or arrange to run the factory themselves. The latter is the course they chose, thanks largely to Robles' advocacy.

The co-op idea had been in the air for a while. In 2006 Robles had attended the World Social Forum in Venezuela and heard a group of electricians discuss the cooperative they had formed, but at the time he wasn't able to pursue the idea. During their "victory tour" around the U.S. in early 2009, however, he and his coworkers got a step closer to starting a co-op. In an interview on Democracy Now! in New York they met Naomi Klein and Avi Lewis, who had made the documentary The Take about factory occupations in Argentina and, since then, have been deeply committed to the cause of worker cooperativism. They introduced Robles to Brendan Martin, founder (in 2004) of a nonprofit called The Working World, which would provide crucial assistance to the New Era Windows cooperative formed later. As stated on TWW's website, it helps design, fund, and carry out cooperative projects - hundreds of them in the last ten years, in Argentina, Nicaragua, and the U.S. While its business model might seem risky, in that it gives low-interest loans to relatively poor people who don't have to pay them back until their businesses make a profit, its loans have a 98 percent repayment rate. $^{362}$

${ }^{362}$ Elie Winninghoff, "The Giving Generation," Barron's, December 3, 2012. 
Martin pitched the idea of a co-op to Robles, but at the moment it was too late: Serious Materials had already stepped in. Robles was hopeful, though. As he recalls, "my answer [to Martin] was: you know what? Things happen. Owners are owners, they close. Sooner or later we could be in that spot, and then we'll give you a call." Almost exactly three years later, his prediction was borne out.

As he says,

when [Serious] announced the close of the factory [in 2012], I keep mention [sic] all during the whole occupationtwelve hours - every single minute talk to the people, we should buy the factory, we could make a co-op. 'Cause I already have the idea. I see the movie The Take and it inspired me a lot. I have the opportunity from Brendan Martin who offered to us the financial support, and he has the dream to start the movement in the United States. So I see it as a big opportunity. ${ }^{363}$

At Robles' request, Leah Fried called Brendan Martin, who was in Argentina but flew to Chicago a couple days later. He met with Robles, Ricky Maclin, and a steward to start planning the co-op, for instance by choosing which workers they wanted to invite into the business. Initially it would have to be a small group of people who could be expected to get along well; later, the co-op could expand. They got in touch, therefore, with a few dozen former employees of Republic, not all of whom were interested. After all, the equipment hadn't even been purchased yet, and the whole idea of starting a coop struck some people as crazy. Many saw themselves exclusively as workers, not bosses, and they couldn't break out of that mindset.

Nevertheless, progress was being made that spring of 2012. At an event showcasing the achievements of the Evergreen cooperatives in Ohio, the small group of planners fortuitously met Dennis Kelleher, executive director of the Center for Workplace Democracy.

${ }^{363}$ Author's interview with Robles, January 8, 2014. 
This institution assists cooperatives and community-based organizations in Chicago through advocacy, technical support, and financing. After hearing about the project that would soon come to fruition as New Era Windows, Kelleher organized classes in cooperative business administration for the workers who had agreed to join the co-op. In the spring and summer of 2012, therefore, when the status of the future business was still very uncertain, workers attended weekly classes run by Kelleher at the UE hall. The content of these classes was useful, but perhaps most important was the fact that - in these doubt-full early months - they brought people together every week and so fostered a group cohesion that, in retrospect, was "absolutely necessary," as Fried says.

One reason cohesion was so necessary is that there were still unforeseen battles ahead. Serious had agreed on February 24 to sell the factory - or rather, its equipment ${ }^{364}$ - instead of liquidating it, thus giving workers the opportunity to buy it. Negotiations between the company and its ex-employees began soon after: the workers painstakingly selected which equipment they wanted to buy and negotiated the prices with Serious, Brendan Martin serving as an intermediary. Things were looking so positive that the 17 future worker-owners took steps to incorporate New Era Windows on May 30 , 2012, though they didn't yet have equipment or a place of business. Negotiations continued for weeks until suddenly, at the beginning of July, Serious informed them it wasn't going to sell its equipment after all- thus reneging on the contract it had signed at the end of February.

Immediately the workers launched a petition on Change.org to pressure Serious to comply with its own prior agreement; within 24 hours, the petition had received 3000 signatures. (Seventy-five thousand more would follow in the next two weeks.) Meanwhile, the UE filed for arbitration over Serious's violation of the February $24^{\text {th }}$ agreement. The next day, July 5 , the union organized a rally in which workers and supporters, armed with stacks of their signed petition,

${ }^{364}$ Serious owned the equipment but not the building, which it leased. 
marched on one of the chief financial backers and board members of Serious Energy, Mesirow Financial. ${ }^{365}$ In less than thirty minutes, the march grew from twenty people to about eighty. Evidently this frightened Serious and its investors, for, in a conciliatory mood now, they promptly got in touch with the workers. "Stop," Robles paraphrases them, "don't go to the media, we're going to work with you guys."

This incident shows, once again, that Glenn Greenwald's characterization of bureaucrats in the National Security Agency applies to functionaries of power everywhere: they're like cockroaches, happy to operate in the dark but extraordinarily skittish once light is shined on them. In most cases they'd rather concede defeat in some battle than have their dark machinations be exposed. Doing so, or threatening to do so, is one of the most powerful weapons in the arsenal of democracy.

So negotiations resumed, continuing through the summer. Meanwhile the search for a new factory continued, since the old one on Goose Island was too expensive and much too large. Even Serious hadn't needed all the space or used all the equipment it had bought. The cooperative, in contrast, would start out small and without a large surplus of cash, a fact that encouraged its members to be much more efficient and sparing in their purchase and use of machinery and facilities than large corporations tend to be. They looked at over ten possible buildings, eventually deciding on one in southwest Chicago that was significantly cheaper than the property on Goose Island.

To pay for the equipment they were buying, each member contributed the $\$ 1000$ that was his or her buy-in to the co-op, and The Working World provided the rest-in fact, more than the rest. It

${ }^{365}$ Laura Flanders, "Workers vs. Investors: Chicago Window Factory in Danger of Liquidation," The Nation, July 4, 2012, http://www.thenation.com/blog/168727/workers-vs-investors-famouswindows-factory-danger-liquidation\# (accessed January 8, 2014); "New Era Windows Workers Continue Struggle With Serious Energy," Chicagoist, July 11, 2012, http://chicagoist.com/2012/07/11. 
raised over $\$ 600,000$, though in the end the equipment cost only about $\$ 400,000$. The rest of the money it raised has served as a line of credit for New Era.

However, the whole cooperative venture almost fell apart again in September, when Serious dropped another bombshell. After months of negotiations over individual pieces of equipment, its executives changed their mind and declared that New Era had to buy everything or nothing. Since it didn't have the money to buy everything, the business could have ended just then, before it even began. Luckily Brendan Martin came to the rescue: he found a company that liquidates factories and arranged for it to buy 60 percent of the equipment while New Era bought 40 percent (which included much it didn't need, such as extra computers, tables, pallets, and lots of odds and ends the workers sold later). The deal was signed, and New Era had its equipment, finally.

The task now was to transport everything from the factory on Goose Island to the new one in south Chicago. Aside from four heavy machines that they hired someone else to transport, the workers moved all the equipment themselves - almost seventy trailers' worth. They hired a driver, but the loading and unloading they did themselves. Robles recalls with pride how effectively they organized this operation. They had bought four trailers from Serious; after filling them up they called the driver, who drove them one by one to the new factory, where another team of workers unloaded them. The efficiency with which they carried this out defied everyone's expectations, as Robles says:

Against all the predictions from the Wrigley people, who's been the owner of the Goose Island building, and against the predictions of the liquidators - they assumed like how the workers gonna move, we don't have experience to do nothing like that. Well, with experienced people [who transported the equipment the liquidators had bought] they moved like four trailers, at most they moved four trailers a day. We reached, in three consecutive days, moving ten 
trailers a day. So we moved around seventy trailers to this facility.

That was in October 2012. In the following months they fixed up the plant, which was not in good shape. Old mattresses were piled high, the ceiling was an ugly brownish color, there were no lights and no heaters. With help from the building owners they cleaned it all out, painted the ceiling white, installed heaters and lights, ran pipes to each machine, and eventually built a break room and a large office on the factory floor. They didn't have fancy architectural drawings to guide them regarding the layout of the plant; instead, they just put the machines where they thought they should be, based on memory. "I was working here, I need this amount of space, this is the next machine, I could put this other one here... We make straight lines better than Republic or Serious," Robles says, "because we tried to do step by step."

Finally, late in the spring of 2013, they were almost ready to open-except for the required fire inspection, which they were worried about. Any little irregularity, whether with the sprinkler system, the fire extinguishers, the proximity of electrical panels to machines, or "all the chemical stuff," could pose a serious problem. It turned out they had no cause for concern, though: they passed the inspection without a hitch, and so were able to open their business on May 9.

Businesses rarely start making a profit very quickly; New Era has not differed much in this regard (though it has been successful more quickly than most businesses). The first summer was spent building up a base of customers, and not much production was done until the fall, which is in any case a more active season for the windows business than summer. In fact, the workers didn't give themselves their first paycheck until the fall. Their pay, which they calculate themselves, is based on a combination of sales and how many hours each person has worked, with everyone receiving the same rate. Nine months after opening, their individual earnings have fluctuated as the number of windows manufactured each week changes. 
As the cooperative has expanded its business, the UE has been an invaluable resource. New Era's worker-owners are still unionized, but the role of the union has of course changed: it now serves to represent the co-op, giving it support with advertising, legal work, promotion among other unions and social justice groups, conflict mediation if that's necessary, and other issues that might arise. For example, if there's a protest or some kind of mass event, the union will get in touch with New Era to send people who can pass out flyers (while wearing their New Era t-shirts) and talk to the media. Also, the UE has connections that help it find customers who otherwise wouldn't even have heard of New Era. Suppose, for instance, that the city or state government wants to weatherize some buildings. If a small co-op offers to supply the windows, the government will just laugh at it. If, on the other hand, a union backed by 35,000 people pressures the government with petitions coming from all over the country and other such tactics, officials will listen. And there's also the influence that the UE can bring to bear on contractors as opposed to end users. All this can add up to the difference between a failed business and a successful one.

The union can perform other services too. At this writing, Leah Fried is arranging to get health insurance for the members of New Era. She's also facilitating the adoption of a "collective bargaining" agreement-not in the traditional sense, as between a boss and employees, but merely in the sense of a set of rules that the members commit themselves to obey. It isn't a particularly urgent issue at the moment, when the business is small and personal conflicts are infrequent, but if and when the cooperative brings in new members it could prove useful to have such a statement of principles and rules.

Brendan Martin has remained just as involved with the co-op as Fried. Amidst his continent-hopping he regularly comes to Chicago to work on behalf of New Era, primarily in sales, meeting with government representatives, construction companies, and other potential customers. Meanwhile, another member of The Working World, Steve Wong, works at New Era in sales, purchasing, technical support, and other areas. In addition, the worker-owners 
energetically advertise themselves, seeking out clients in person around the city.

As a result, business is steadily growing. Robles recalls that his first paycheck in the fall of 2013 was only $\$ 20$ - and yet even that was satisfying, because it was symbolic. "It was money from our own work, from our own factory, from our own product. That was a big thing, to make me successful, to make me feel comfortable and happy, 'cause in the end it was the fruit of all our work we put in this." In less than ten weeks after their first check, everyone's biweekly pay had shot up to $\$ 580$. Winter is an off season in the industry, but they expect sales to increase dramatically in the spring.

When talking to the members, it's striking how positive and optimistic they are about the cooperative. Joel Cruz, a middle-aged man with six children, thinks his future is much more secure now, just as the present is much more satisfying. "My life is different. Maybe next year, with more customers, I forgot everything, my problems [in 2008 and 2012]... You know, when you're in the company, you have a supervisor; the supervisor say, 'Why you come in late? Hey, what happen? You talk too much, you go to line! Back to line, back to work!' Now, nothing like that." As one would expect, he's motivated to work harder now that he partly owns his business; at the same time, he's able to relax occasionally without worrying he'll be punished. For some of the members, indeed, the co-op also serves as a kind of social club, and they enjoy coming to work to see their friends. The only complaint Cruz has-which is shared by the others - is that, for now, the pay is too little. To provide for his family he has to work a second job on the weekends, as a saxophonist with a Mexican band. Other members, such as Robles, have had to be supported by their spouses.

William Swanson is, if anything, even more enthusiastic than Cruz, about everything except the pay (so far). He worked at Republic for 26 years, then at Serious for two years, and now it seems that for the first time he actually enjoys his job. He views it as a kind of adventure, an adventure in freedom-from-a-boss. For him, that's by far the best part. But he also enjoys the learning process, learning how to do purchasing (which is his main responsibility now) 
and the other duties they all share. "It's fun! It's knowledge, we're learning. That's the good part about it. We're learning something, and we can always have this, you know? We'll always have this under our belt. And we ain't got no bosses standing over us telling 'C'mere, ya gotta do this!,' 'cause we know what we gotta do. If we don't do it, we don't make money." Ricky Maclin has the same attitude as Swanson-something like exhilaration — and is absolutely confident about the future.

The co-op has five female members, whose attitudes toward their business do not differ much from their male coworkers'. Arizona Stingley worked at Republic for twenty years, then Serious, and now is loving her new role as a worker-owner. The small size of the business and its cooperative nature make it feel like a "family," very different from the impersonal environment of her two previous employers. Neither she nor Victoria Amaya, another long-term employee of Republic, has noticed any sexism at New Era; in fact, Victoria is one of the more dominant voices in the business and at their weekly meetings. These meetings, at which important business decisions are made (such as what materials to buy or how to address some problem that's arisen), are structured fairly informally, typically with a 75 percent supermajority being required on any given decision.

In short, things are going smoothly at New Era. The members hope to start a second shift and bring in new people in 2014, though they haven't yet decided on the specifics of that process. New members will probably have to pay a larger buy-in than the current members did, since the latter did all the hard, unpaid work of getting the business started. For now, though, they're just looking forward to enjoying the economic fruits of their intensive two-years-long labor.

Several lessons can be drawn from the history outlined in this chapter. First, militancy works. Or rather, it can work, if it has institutional support such as the UE and The Working World provided in this case. At each step of the way, it was by acting "impolitely," even illegally, that the workers were heard and got justice. The whole of labor history, of course, confirms this 
conclusion. For example, it was the sit-down strikes of 1936 and 1937 that led to the unionization of the automobile and other industries, whereas the concessionary bargaining of the 1980s and later did nothing to stop the decline of the union movement. It's time that mainstream American unions took the UE as their model.

The other obvious lesson is that media savvy is an invaluable tool for activists and workers. The slogan Leah Fried came up with in 2008, "Banks got bailed out, we got sold out," perfectly captured the public's mood and justified the workers' struggle. It was a catchy soundbite that simultaneously directed ire at banks and highlighted the injustice of what had happened to millions of people in the country. It's necessary to spin stories in such a way that the media will cover them, and then to conduct visible protest actions. Especially if one has already built relationships among the liberal elite, it's quite possible that militant tactics will force authorities to come to the bargaining table, or even to concede all demands so that the issue goes away.

Regarding the cooperative itself, the history of New Era is vivid confirmation that starting a sizable co-op is extremely difficult and labor-intensive, and requires institutional guidance and support. Without Brendan Martin and The Working World, or the UE and its skilled organizers, New Era Windows never would have happened. If the U.S. had anything like a sensible industrial policy, government at all levels would provide much of the support needed to start co-ops and so give employment to some of the millions who desperately need it. For now, though, it seems that activists and visionaries will have to fill in the gap left by the government's inaction, while simultaneously pressing for policy changes.

A more encouraging lesson comes out of New Era's capitalintensiveness: it reminds us that worker co-ops need not be limited to labor-intensive industries. The record of Mondragon already demonstrates this, as does the cooperative sector in Emilia-Romagna and the success of other high-tech co-ops such as the long-running 
Isthmus Engineering \& Manufacturing. ${ }^{366}$ Still, to have a successful high-tech cooperative run by a working-class membership of Hispanics and African-Americans is yet another nail in the coffin of conservative conventional wisdom. Indeed, the diversity of the workforce demonstrates that, despite the scholarly stereotypes summarized in chapter two, homogeneity of cultural background is by no means a prerequisite of successful worker co-ops (however much it may conduce to success). What matter, rather, are commitment to the business and some degree of flexibility and amiability in relations with coworkers.

The broadest implication of the New Era Windows story is that one doesn't need a sophisticated formal education or a middle-class background or millions of dollars to stand up to corporate titans and win, or to start an ambitious manufacturing cooperative that is poised for indefinite expansion a few months after its inception. Such qualities as creativity, intelligence, ambition, and initiative are not limited to any one class of people but spread evenly throughout the population. It so happens that current social structures are designed to stultify these qualities in people who don't belong to the elite, but with determination, capitalist resistance can be overcome. If working people, with assistance from activists, tap into their enormous collective reserves of energy and defiance, there are no limits to what they can accomplish.

\footnotetext{
${ }^{366}$ See Michael Billeaux et al., "Worker Cooperative Case Study: Isthmus Engineering \& Manufacturing," University of Wisconsin Center for Cooperatives, staff paper no. 9 (October 2011).
} 



\section{CHAPTER SIX CONCLUDING THOUGHTS ON REVOLUTION}

While worker cooperatives are the main subject of this book, I am more interested in revolution than cooperatives for their own sake. The future of civilization is what concerns me, the future of cooperatives only derivatively. Given the unsustainable nature of corporate capitalism, society will necessarily undergo a transition to a different system sooner or later. In chapter four I tried to answer the question of how that transition might happen, admittedly in very sketchy ways. No certain or precise answer is possible. I used Marxism because no other relevant set of intellectual tools approaches it in explanatory power, theoretical fruitfulness, or historical resonance. The revision I made to Marxism, though, is important enough to warrant further consideration, not only for intellectual or academic reasons but because it bears on debates that activists have been having since the split between Marx and Bakunin in the nineteenth century. The most important implication of my revision is that the opposition between Marxists and anarchists virtually dissolves upon a deeper understanding of Marxism itself.

Now, there is a sense in which, say, Noam Chomsky's attitude toward such debates as these is right: they don't matter, they're elitist and intellectually masturbatory. We know what's necessary to bring about social change: education and organization. Education about how the world works - namely through class war, exploitation of workers, big business's near-total control of national politics, etc.and organization to take over factories, defend public resources, and so on. Chomsky's anti-intellectualism is refreshing and largely valid. On the other hand, insofar as millions of people do have a sectarian commitment to some particular ideology, it is not merely an intellectual exercise to argue that sectarianism is counterproductive and based on misunderstandings. Doing so can have positive practical consequences. The world needs an ecumenical left, a left that can countenance and integrate all kinds of radicalism, from cooperatives to political parties. Marxists, anarchists, feminists, environmentalists, unionists, anti-racism activists, and other such 
people ought to understand that they're basically on the same side and should work together.

I have to admit I'm also interested in theory for its own sake (and for the sake of interpreting history), and accordingly will elaborate on the discussion in chapter four in order to clarify what a twenty-first century Marxism entails. I'll return briefly to the topic of cooperatives later in the chapter.

Since the publication in 1978 of G.A. Cohen's Karl Marx's Theory of History: A Defence, the academic school of Analytical Marxism has tried to reconstruct Marx's theory of history in the light of the Anglo-American philosophical pursuit of logical precision. Debates have erupted over the role that such questionable methods as functional explanation play in Marxism, and the discussions of Marx's "base/superstructure" metaphor could fill a small library. As is usual with academics, most of this labored intellection has been unnecessary and unproductive. Being an academic, I would, nonetheless, contribute to it myself were this an academic book; instead I'll make a few suggestions that eschew the obsession with logical precision in favor of old-fashioned commonsense reasoning. After making a couple observations on the base/superstructure metaphor, I'll confine myself to the theory of revolution.

The imagery of "economic base vs. political, ideological, and cultural superstructure" is woefully imprecise but intuitively reasonable, which is why it still commands attention even after generations of criticism. Its meaning and truth are revealed in the single consideration that the institutions and institutional actors with the greatest access to resources are going to have the greatest influence over society. Fewer resources, less influence. Institutions directly involved in the production and accumulation of resourcesof money, capital, and technology - are naturally going to have the most direct access to these resources, and hence the greatest control over them. The people who control these institutions, then, are going to have more power than other people, and they will seek to make other institutions (and ideas) throughout society "compatible" with their power or subservient to it. Which, in effect, means making 
them compatible with the form of organizing relations of production in that society that has the most control over the most resources. In other words, the "dominant mode of production." In non-prehistoric societies, the class structure and implicit class struggle, which are defined by the relations between antagonistic positions in the mode of production, will therefore be central to social dynamics. The more exploitation of the producing class(es), the more power there will be in the hands of the exploiting class(es), i.e., those who occupy the dominant positions in the dominant mode of production. (Their dominant position is a function of their control over the resources necessary to force others to produce for them.) The exploiters will try to increase exploitation as the exploited try to diminish it. The vicissitudes of this struggle will go far towards explaining other political and cultural phenomena, because the struggle-which is integrally connected to the evolution of the relations of production, of the class structure, of economic institutions, as well as the closely related evolution of the forces of production-largely determines who has how many and what kinds of resources when, what sorts of institutions and values the people with resources will promote, etc. ${ }^{367}$

All this is sheer common sense, although its schematic nature demands the sort of elaboration for which I don't have space here. It leads directly into the theory of revolution, which I'll consider now. Analytical Marxists have spent decades wringing their hands over the supposed Marxist commitment to functional explanation, which is scientifically incomplete compared to causal explanation. For example, to say that birds have hollow bones because this allows them to fly - which is a functional explanation - is not to give a complete explanation, which requires invoking the causal mechanism Darwin identified of natural selection by random variation. Similarly, Marx's argument that revolution happens when production relations start to fetter the use and development of productive forces gives no causal mechanism to explain why this is

${ }^{367}$ This paragraph is taken from my Notes of an Underground Humanist, $146,147$. 
the case. As I said earlier, my revision supplies the necessary mechanism, and thus renders all the hand-wringing over functional explanation superfluous. Such explanations are merely shorthand for causal accounts.

On the basis of my arguments, one can translate problematic statements by Marx into statements that are both substantive and possibly true. An example is his hypothesis that "No social order is ever destroyed before all the productive forces for which it is sufficient have been developed, and new superior relations of production never replace older ones before the material conditions for their existence have matured within the framework of the old society." Said in this way, the statement is objectionable. It's functionalist and isn't even entirely meaningful. One can translate it, though, as follows. "The overwhelming mass impetus necessary to effect a revolution in the dominant mode of production will not arise until the latter has nearly exhausted its resources, has reached a point of dysfunction such that it cannot efficiently use or develop productive forces any further; however, there also has to exist an alternative mode of production that has reached such a level of societal influence that it can withstand attempts by the old ruling class to destroy it." In some ways this is quite different from Marx's original statement, but it is both inspired by it and more cogent.

This translation also answers the question that no one has ever satisfactorily answered, namely, why hasn't a truly "post-capitalist" revolution occurred anywhere despite all the problems with capitalism? It isn't hard to think of various superficial reasons, such as that the capitalist class has had enough means of violence at its disposal to crush rebellions. What is needed, though, is a more comprehensive answer that acknowledges that the failure of past revolutions necessitates a substantial correction to orthodox Marxism, which predicted revolution long ago. But what, precisely, has to be corrected?

It turns out the answer is pretty simple: there is not only one condition for the success of revolution but two. First, capitalism has to be fettering the productive forces such that the majority of people live in poverty and oppression relative to the conditions they could 
be living in if society's productive potential were not so shackled (or used mainly for the benefit of a tiny elite). This is the condition Marx stated. It is what gives people the motivation to build a new society. The second condition, to repeat, is that a more rational or socially appropriate set of production relations has to already be spreading and attracting hundreds of millions of people worldwide who understand its superiority to the old economy. If this condition doesn't exist, then it doesn't matter how much "fettering" the old production relations are guilty of; they'll continue to predominate. The ruling class will still be able to maintain its hold on power, because it commands more resources than its relatively impoverished opponents do. In fact, radicals should be resigned to the fact that the capitalist class will retain substantial control over society for a long time to come, until capitalism has virtually no reserves of power left - as the European feudal aristocracy had virtually none left in the early twentieth century, when its remnants were still frantically trying to maintain their hold on the reins of power. (It took two world wars to destroy all vestiges of feudalism in the West.) Revolution is not a matter of swiftly overthrowing the state, shooting all your opponents, and then organizing a "new society" from the top down.

One might ask if the second condition I've identified will ever arrive, given that we're still waiting for it. The answer has to be yes, if only because the unsustainable nature of capitalism has become blindingly obvious. Unless the human species completely destroys itself, which likely isn't possible, a new mode of production will necessarily evolve as the old one succumbs to its contradictions and catastrophic environmental consequences. It's worth remembering, too, that the fact that radicals have been expecting an imminent socialist revolution since the 1840 s means precisely nothing-except that they've been wildly over-optimistic and have wildly misunderstood history. Feudalism was around for many centuries; industrial capitalism has been around for barely two, and for less than fifty years in much of the world. It would be nice if history went faster, but, as it happens, it prefers to go very slowly. 
Thus, as painful as it is for a Marx-lover to admit this, it's clear that Marx wildly misinterpreted mid-nineteenth-century radicalism. It's time we revised our understanding of history and resurrected the idea of "historical necessity." All the popular discontent and rebellions from 1848 to 1871 to 1917 and afterwards were nothing like what Marx thought or would have thought - were not pregnant with historic potential in the way he hoped: all these battles were fought by heterogeneous masses, some of them, like the craftsmen who felt themselves besieged by this terrifying new thing called industrial capitalism, "reactionary radicals," 368 and others proletarians in the classic Marxist sense, but whose miseries could have been (and eventually were) effectively meliorated by mere reform. They were not proletarian armies "disciplined, united, and organized by the process of capitalist production" 369 but disparate masses of the lower classes with disparate interests-some progressive, some reactionary-temporarily thrown together by the sheer chaos of early industrialism. As capitalism matured in the twentieth century, the working class was "disciplined and united" into explicit reformism, and this was both good and inevitable. When reform is possible, revolution is not. Only when broad welfare-statist reform has become impossible is (gradual) revolution possible, because the dispossessed are forced to turn from obvious reformist solutions to less-obvious radical ones.

In other words, there is no conflict between reform and revolution. People should always be fighting for reform. Only when it becomes impossible on a large scale does the question of revolution arise.

This idea that "necessity" plays some role in history begs the question: what about the twentieth-century revolutions in Russia, China, Cuba, and so on? What did they "mean"? Were they socialist revolutions, as their leaders claimed? Or merely some form of radical coup? Do they have any implications with regard to the ideas I've

\footnotetext{
${ }^{368}$ Craig Calhoun, "The Radicalism of Tradition."

${ }^{369}$ Marx, quoted in Murray Bookchin, The Spanish Anarchists: The Heroic Years, 1868-1936 (San Francisco: AK Press, 1998), 281.
} 
presented in this book? Such questions are made more important by the fact that these "revolutions"- the Russian in particular-still bewitch many radicals, who mistakenly look back to them for inspiration and strategic lessons. The reality is that they have very little to say to us who live in advanced capitalist societies, and they were certainly nothing like Marxist or socialist revolutions. I've discussed the Russian example briefly elsewhere, and I'll be even briefer here. ${ }^{370}$

Good scholarly accounts of the Russian Revolution, such as Christopher Read's From Tsar to Soviets (1996) and Orlando Figes' A People's Tragedy (1996), make several facts abundantly clear. First, the revolution was something of a historical accident. A thousand incidents leading up to the October coup had to go just right in order for Lenin's wild schemes (considered wild by his associates) to succeed, and if the prime minister Kerensky had shown a little backbone the Bolshevik leadership might have ended up ignominiously imprisoned months before the coup was attempted. And yes, the events of October were a coup and not a mass uprising, as any disinterested retrospective observer has to admit. Conspiratorially, secretively, Trotsky, Lenin, and the Military Revolutionary Committee (MRC) of the Petrograd Soviet planned out what would happen on October 24 and the following few days, namely that soldiers loyal to the MRC would occupy the city's telegraph offices, the railway station, nearby bridges, etc., and then take over the Provisional Government's headquarters at the Winter Palace. The coup was a swift, decisive series of acts that triggered hardly any fighting and barely disrupted the city's functioning. In the following weeks and months the Bolsheviks miraculously clung to power, perhaps in part because of Lenin's immediate moves to establish dictatorial control over the government.

The main reason, of course, that the party was able to stay in power in the subsequent weeks was that, for the moment, it had the

${ }^{370}$ See Notes of an Underground Humanist, chapter two. My paper "Causes of the Russian Revolution" (on www.academia.edu) gives a more detailed summary of the events and commentary on them. 
support of most soldiers, industrial workers, and peasants. Why? Because Lenin was an astute politician. Since April 1917 he had distanced the Bolshevik party from the unpopular Provisional Government and used very popular slogans to propagandize for his party, in particular "All power to the soviets!"371 and "Peace, bread, land!" The vast majority of the population wanted an immediate end to the European war that Russia was mired in; urban workers, many starving, wanted an end to the shortages of food; and peasants wanted carte blanche to seize aristocrats' land. So Lenin spent months telling them that the Bolsheviks would grant their wishes. Not surprisingly, he became exceedingly popular, such that when his coup occurred most soldiers in the vicinity of Petrograd accepted it.

In the following years, the Bolshevik dictatorship and bureaucracy grew so bloated and inefficient that even Lenin complained about it. Workers' earlier factory takeovers (before the October coup) were reversed as a hierarchy of managers and bosses was reinstalled. Popular uprisings against the Red dictatorship were crushed in the context of civil war and afterwards, as even the Bolsheviks' former supporters grew terribly disillusioned with this "socialist" government that was in many ways more repressive than tsardom. Russia was so devastated by its civil war that in 1921 Lenin deemed it necessary to end forced grain requisitions and partially reverse some of the nationalizations of industry that had taken place since 1918. His New Economic Policy began, the most important achievement of which was to restore market relations to agriculture and thereby stimulate food production. This partial "retreat" to capitalism ended in the late 1920s, when Stalin ordered a return to full nationalization of the economy, organized the collectivization of agriculture, and began his Five-Year Plans to industrialize the Soviet Union. The Stalinist bureaucracy proceeded to liquidate millions of people and effectively enslave the rest for the sake of developing the USSR's industry and military. This situation lasted until the

371 The soviets were popular, relatively democratic institutions that had sprung up in many cities and towns after the February revolt against the tsar's rule. 
country's collapse in 1991 (though things did improve after Stalin's death).

Now, does any of this seem like workers' democratic control of the economy? That's what socialism means, after all. Does a secretly planned coup in a backward, semi-feudal country eighty percent full of peasants seem like a mass working-class revolution in an advanced capitalist country? The historical meaning of the so-called Russian Revolution is no mystery. In the late nineteenth and early twentieth centuries (before the Bolsheviks took over) Russia was undergoing the transition that some Western European states had already experienced, from being a late-feudal country with an absolutist monarchy to being a semi-industrial capitalist country with either a constitutional monarchy or some other form of representative government. Unfortunately, Nicholas II was a desperately incompetent ruler reminiscent of France's Louis XVI, not least in being utterly resistant to even minor democratic reforms that the population was clamoring for. Combined with the unstable state of Europe at the time, riven by imperialism, nationalism, racism, and an international arms race-all of which led to the height of "instability," World War I-this fact of the tsar's incompetence made it likely that Russia's decades-long "bourgeois revolution" would go off the rails sooner or later. It finally did, in the context of a world war that exacerbated the population's grievances. A new elite with good intentions took advantage of mass discontent to seize power - and used it to establish a much more vicious kind of state capitalism than existed in the West. Classic historical irony.

The point is that none of this was revolution, at least not in the Marxian sense. The same is true of the Chinese case. These signified nothing but transitions to a mature capitalism that got waylaid for a few decades and ended up in an (inevitable) return to paradigmatic capitalism by the 1990s or 2000s. The major lessons they hold for us are in how not to do things.

The Russian case had another pernicious consequence: it cemented the idea in the minds of many Marxists that the way to make a revolution is to seize the national state and then remake society. This is exactly the opposite of the proper path, and the 
opposite of what Marxism (despite Marx) prescribes. In chapter four I sketched the reasoning behind my revision, or rather purification, of Marxism, showing how it follows from a simple conceptual alteration and dramatically changes the thrust of the theory of revolution. I'll recapitulate that argument now before considering how it bears on the old, and rather tired, debate between Marxism and anarchism. ${ }^{372}$

To frame the conflict that leads to revolution as between two sets of production relations rather than between one set and the productive forces it shackles (as Marx does) has other advantages besides making the theory more meaningful, supplying causal mechanisms that answer academic complaints about functional explanation, and answering the question of why revolution hasn't happened yet. It also gives the theory a grassroots, democratic emphasis, since the new set of production relations-which, in the context of the transition out of capitalism, is necessarily "cooperative" as opposed to antagonistic - cannot but emerge gradually from the energies of "ordinary people." In the case of the post-capitalist transition, they emerge from ordinary people's efforts to adapt to a world in crisis, efforts that take the form of creating cooperatives of all kinds, joining movements for public banking and municipal ownership, pressing for nationalization of key industries, joining radical political parties with agendas to confiscate wealth, agitating for comprehensive participatory budgeting, taking over factories and making them worker cooperatives, demanding improved and cheaper public resources, and forcing expansion of the social and solidarity economy. Eventually, perhaps, one can talk about taking over the national state (in whatever form it may exist in), but not until the corporate capitalist class has been enormously weakened by crisis and all the democratic initiatives that have accumulated over decades.

${ }^{372}$ A good introduction to anarchism is Daniel Guérin's Anarchism: From Theory to Practice (New York: Monthly Review Press, 1970). His No Gods, No Masters: An Anthology of Anarchism (San Francisco: AK Press, 1998) is a panorama of the original writings. 
It's obvious how these arguments bear on the "Marxism vs. anarchism" issue: they bring Marxism closer to anarchism, by jettisoning the (implicit) statism of most orthodox Marxists and Leninists. In fact, I've argued that the essence of Marxism always was anarchist in this way, since the idea of a national state organizing a radically new economy-abolishing class structures, ending authoritarian hierarchies, eliminating the exploitation of workers and an elite's appropriation of the surplus they produce-is both a thoroughly "un-dialectical" notion and inexplicable in Marxian terms. Historical actors almost never understand the broad significance of their acts or succeed in their designs as they interpret them (a Marxian apothegm ironically borne out by the Bolsheviks' total misunderstanding of what they were doing, thinking they were establishing socialism or leading a working-class revolution when they were really, in effect, just opportunistic political adventurers who founded a regime that magnified some of the worst aspects of capitalism). History is always an agonizingly slow and unconscious process; one cannot sit in the driver's seat, so to speak, look at a map, and direct it where to go. If one tries, as Lenin did, one will find that History in fact is still in control and has another destination in mind.

Even the old Marxist strategy of forming workers' parties and entering the electoral arena-which is something that anarchists have traditionally been hostile to, since they regard politics and the state as an evil-is not especially "Marxist," though it is realistic and can produce gains for the working class. Its un-Marxist element is that such parties can, and historically have, become integrated into the dominant political and economic order, so that their radical edge is dulled and the essential antagonism between labor and capital is blurred. They can end up functioning as props for the stability of the system they were originally created to overthrow. This was the fate, for example, of the German Social-Democratic Party, which already by the time of World War I had shed much of its former radicalism. (It supported Germany in the war, a nationalist position anathema to many Marxists of the time.) Later, many European Communist parties followed a similar trajectory. Among the causes of this ironic 
fact is that mass bureaucracies, such as develop in political parties, are intrinsically conservative-routinized, centralized, and undemocratic, such that an oligarchy arises at the top which seeks to preserve its own power and thus the institutional and social configurations that have allowed it to achieve power. ${ }^{373}$ All this is contrary to the radical and democratic thrust of Marxism.

In addition, there is the tendency for party activity to degenerate into the "parliamentary cretinism" that Marx and Engels loathed, "a disorder which penetrates its unfortunate victims with the solemn conviction that the whole world, its history and future, are governed and determined by a majority of votes in that particular representative body which has the honor to count them among its members, and that all and everything going on outside the walls of their house...is nothing compared with the incommensurable events hinging upon the important question, whatever it may be, just at that moment occupying the attention of their honorable house." ${ }^{374}$ In general, the real conditions and struggles of the working class can be forgotten or neglected by an insular party elite seduced by power or its illusion.

If there is nothing essentially Marxist about forming political parties, so there is nothing $u n$-Marxist about the favored anarchist tactic of "direct action." Marx himself and most of his followers have consistently supported and engaged in direct action of all kinds, including strikes, sit-ins, armed insurrections, and every manifestation of civil disobedience. Indeed, insofar as direct action highlights antagonistic and asymmetric power relations, striking at the fulcrum of society in the economic sphere or demonstrating that the rule of the powerful rests on pure violence, it emerges straight from the logic of Marxism. Here too, then, anarchism and Marxism are one.

${ }^{373}$ See Robert Michels, Political Parties: A Sociological Study of the Oligarchical Tendencies of Modern Democracy (New York: Dover Publications, 1959 (1911)).

${ }^{374}$ Friedrich Engels, Revolution and Counter-Revolution in Germany (1852), chapter 15. 
If my revision of Marx's conception of revolution is justified, it follows that the ideas bearing his name have much more in common with anarcho-syndicalism than Leninist vanguardism, elitism, and statism. Anarcho-syndicalism is committed to the task of building the new society within the old, according to its understanding that "every new social structure makes organs for itself in the body of the old organism," as Rudolf Rocker writes. "Without this preliminary any social evolution is unthinkable. Even revolutions can only develop and mature the germs which already exist and have made their way into the consciousness of men; they cannot themselves create these germs or generate new worlds out of nothing. $" 375$ This statement seems like common sense, but, judging by the writings and practice of a number of Marxists, it is either beyond them or they don't understand its implications. The institutions around which anarcho-syndicalists hope to construct a new society are trade unions and labor councils-organized in federations and possessing somewhat different functions than they have in capitalist societybut whatever one thinks of these specific institutions as germs of the future, one can agree with the basic premise of prefigurative politics (or economics). And it is this that is, or should be seen as, quintessentially Marxist. The new society will necessarily be erected on the basis of new production relations, and these will necessarily emerge through generations of popular struggle in the framework of a dying corporate capitalism.

In addition, the "economism" of anarcho-syndicalism that Gramsci so deplored is of course reminiscent of Marxism's materialism and economism. Both schools of thought privilege economics over politics and culture, focusing on economic struggles and such tools of working-class agency as trade unions and labor councils. For both, the class struggle is paramount. For both, workers' self-organization is the means to triumph over capitalism. James P. Cannon has a telling remark in the context of a discussion of the anarcho-syndicalist IWW: "The IWW borrowed something

${ }^{375}$ Rudolf Rocker, Anarcho-Syndicalism, 58. 
from Marxism; quite a bit, in fact. Its two principal weapons - the doctrine of the class struggle and the idea that the workers must accomplish their own emancipation through their own organized power - came from this mighty arsenal." ${ }^{376}$ The very life and work of Marx evince an unshakeable commitment to the idea of workingclass initiative, "self-activity" (Selbsttätigkeit), self-organization (with the assistance of dedicated organizers, a qualification accepted by every leftist worthy of the name). The word "self-activity" evolved into the even more anarchist concept of "spontaneity" under the pen of Marx's disciple Rosa Luxemburg, who devoted herself to elaborating and acting on the Marxist belief in workers' dignity, rationality, and creativity.

For instance, in her pamphlet "Marxism vs. Leninism" Luxemburg inveighs against the "military ultra-centralism" in party organization that Lenin advocates, counterposing it to the spontaneity and vitality of a living revolutionary movement organically connected to the working masses. Her concluding sentence even harks to Kant, the philosopher par excellence of human freedom and dignity: "Historically, the errors committed by a truly revolutionary movement are infinitely more fruitful than the infallibility of the cleverest Central Committee." ${ }^{377}$ (Compare the quotation from Kant in chapter two of this book.) "The working class," she declares, "demands the right to make its mistakes and learn in the dialectic of history." Left-Marxism, i.e., true Marxism, thus merges with anarchism, the only remaining task being to scrap the impurity of "a dictatorship of the proletariat"-which simultaneously updates Marxism for the twenty-first century and provides a theoretical framework to interpret the new and growing alternative economy, including worker cooperatives.

To give due credit to history, however, we should remember that the old statist formulations favored by a broad swath of radicals were a product of their time and appropriate to it. They were fantasies that

${ }^{376}$ James P. Cannon, “The I.W.W.” (1955), available at www.marxists.org.

377 Rosa Luxemburg, "The Russian Revolution" and "Leninism or Marxism?" (Ann Arbor: University of Michigan Press, 1961/2000), 108. 
never could have been realized, but, given their historical context, they were powerfully appealing and may even have seemed plausible. The nation-state was still in the ascendant-a fact that many Marxists would have denied, believing on the contrary that states had entered their terminal phase already in the early twentieth century. But Marxists' overwhelming commitment to state action"everything for the sake of taking over the state as soon as possible!"-itself belied their hopes, for it grew unconsciously out of the social environment of capitalist governments consolidating their rule, expanding their bureaucracies, regulating behavior ever more intensively, reaching ever further into society's nooks and crannies to take control, growing more aggressive in every respect. It was perfectly reasonable in this context to think that revolution necessitated seizure of the state apparatus and manipulation of it or "smashing" of it for one's own purposes. And the anarchist notion that political activity was unnecessary, that revolution could proceed automatically from a general strike or a succession of them that would bring the state to its knees, was utterly utopian. As if other states wouldn't immediately send in their armies to crush the workers if things got really serious!

While governments therefore had to be reckoned with"seized"-because of their vitality, they were not yet the unimaginably hypertrophied entities they became later and are today. Today, it's just idiotic to think "the working class" can take over a national government; a hundred or more years ago, it wasn't quite so idiotic. Especially considering the vibrancy of labor movements then, the radical consciousness and militancy of a sizable proportion of the working class, the wide spectrum of political parties, and the tumult of a civilization experiencing transformations unique in history, it was surely easy to believe, if one wanted to, that successive conquests of national governments were possible. In retrospect we can see how impossible that was, and maybe intelligent people should have known better; but the combination of moral outrage and frenzied hope has ambiguous cognitive consequences. Certainly when reading radical tracts of the time, one gets swept up in the emotion and the compelling logic and is almost astounded that 
revolution didn't happen. But then in the cold light of reason one remembers that history is slow, and that ideologies and intellectual self-interpretations are never scientifically accurate.

Anarchists and Marxists had one conviction in common (aside from their shared moral critique of capitalism and vision of an ideal society): they both thought that a revolutionary rupture was possible and desirable. They had a millennial faith in the coming of a redemptive moment that would, so to speak, wash away humanity's sins. By concerted action, the working class would with one fell blow, or a series of blows, overturn capitalist relations and establish socialist ones. This is the basic utopian mistake that Marxism (if purified) can prove wrong but anarchism cannot, because it doesn't have the theoretical equipment to do so. Even anarcho-syndicalists, despite their verbal recognition that the seeds of the new society had to be planted in the old, shared the utopian belief in a possible historical rupture, not understanding that the only feasible way to realize their "prefigurative politics" was to build up a new mode or modes of production over generations in the womb of the old regime.

Since this was historically impossible eighty or a hundred years ago, when the capitalist nation-state was waxing in power, it would have struck revolutionaries as much more unreasonable and utopian than the hope for a sudden social upheaval. It made some sense then to adopt the Marxist attitude of contempt for worker cooperatives and other such "interstitial" endeavors as being distractions from real revolutionary work. As the capitalist state and civil society continue disintegrating in the coming decades, that attitude will no longer make historical sense. The arguments I've put forward in this book will seem merely truistic. The necessity for a wide range of revolutionary strategies, from interstitial to politically confrontational, will be obvious - for the interstitial will be the seeds that will have to be guarded and supported by the politically confrontational, which itself will be increasingly reliant on the interstitial for access to resources and a base of support.

- History is kind enough to offer its own, correct, solutions to old problems. Hegel was right about this. The truth appears when the moment is ripe. 
In the end, doctrinal points about Marxism and anarchism are not as important as the single overriding imperative that anarchists, Marxists, and other radicals have too often violated: work together, don't consume oneself and each other in sectarian squabbles. Strict adherence to points of principle is sterile and counterproductive. David Graeber probably thinks he is espousing a magnanimous position when he says that anarchists ought to be "willing to work in broad coalitions as long as they work on horizontal principles," but even this seems inadmissibly sectarian. ${ }^{378}$ Surely it's conceivable that coalitions not organized on anarchist principles can do valuable work. Hierarchy, even in a moderate form, may be a violation of human dignity, but the world is in such a state that activists should be prepared to tolerate hierarchy for the sake of getting things done. Likewise, it's ridiculous for Leninists, or anyone, to refuse to work with anarchists, or to refuse to support worker cooperativism. It should be common sense that the transition to a new civilization will happen on multiple axes.

For the sake of clarity, though, I do think it would be useful for leftists to abandon their typically voluntaristic conceptualization of radical change. It's an attitude strikingly common among every group from centrist liberals to Leninists to anarchists. Given the balance of forces, it's natural for activists to interpret their task as that of battling overwhelming tendencies, of pushing back against reactionary entities with exponentially more power and resources than the left and its popular constituency have. One of the problems with such an attitude, at least in the context of hope for systemic change, is that it sets one up for disappointment: historical movements on the colossal scale of neoliberalism cannot be halted in their tracks or reversed by some counter-organizing among trade unions and their allies. That simply isn't how history works, nor does the democratic resistance have anything remotely comparable to the resources of the global corporate elite. In particular, it is hopelessly

378 David Graeber, The Democracy Project: A History, A Crisis, A Movement (New York: Spiegel \& Grau, 2013), 89. 
benighted to think (as, for example, the editors of Jacobin apparently do) that a revival of the centralized welfare state is possible. ${ }^{379}$ That social formation was appropriate to a time of industrial unionism and limited international mobility of capital; it has been dying for forty years (starting in the U.S. and U.K.), and no such magical incantation as "We propose a new anti-austerity coalition" can call it back to life. Coalitions of that sort are desperately needed, and their targets should be at every level of government, but their outcome will not be a new manifestation of twentieth-century social democracy.

The proper way for a radical to conceive of his activism is in terms of the speeding up of current historical trends, not their interruption or reversal. Systemic trends have never been reversed, and cannot be. What radicals are doing now, and should be doing, is to contribute to the (self-)undermining of corporate capitalism and construction of an alternative. This self-undermining is the trend we are witnessing, which coincides with the trend to carry capitalism to its most pathological extremes. Just as the earlier liberal phase of capitalism's history eventuated in the Great Depression and had to come to such an end - this was its natural endpoint, even its telos, so to speak ${ }^{380}$ - so the current neoliberal phase cannot but end in a virtual disintegration of the nation-state, its social fabric, and its political economy. That is the historical "meaning" and "mission" of

\footnotetext{
${ }^{379}$ Peter Frase and Bhaskar Sunkara, "The Welfare State of America."

${ }^{380}$ See, e.g., Richard Du Boff, Accumulation and Power, 91: "What had really happened between 1929 and 1933 is that the institutions of nineteenth-century free market growth broke down, beyond repair. Had the chain of circumstances been 'right,' it could have occurred in 1920-21 or possibly 1907." Some academics like to mock Marx for his "teleological" conceptions, as if invoking that term constitutes an argument. This lazy mode of pseudo-argumentation, which simply assumes that anything hinting of teleology must therefore be wrong, is a legacy of the shallow positivism that has guided mainstream social science for too long.
} 
neoliberalism, its essence, its "secret," as Marx might have said. ${ }^{381}$ One should understand this and interpret one's activism accordingly.

Again, most leftists don't like to admit that things have to get worse before they get better, preferring the liberal's optimistic faith that if only we got our act together and willed a system-wide change for the better-perhaps a return to the welfare state-it could happen. No acute social crisis is necessary, only determination and competence. This elevation of will above objective social conditions and possibilities, aside from being the opposite of Marxism, is reminiscent of Lenin, who evidently thought a revolution could emanate from the will of one or two men (if they organized a coup and so on). One might even agree with what Orlando Figes says in the following comments:

All the main components of Lenin's doctrine - the stress on the need for a disciplined revolutionary vanguard; the belief that action (the "subjective factor") could alter the objective course of history (and in particular that seizure of the state apparatus could bring about a social revolution); his defense of Jacobin methods of dictatorship; his contempt for liberals and democrats (and indeed for socialists who compromised with them) - all these stemmed not so much from Marx as from the Russian revolutionary tradition. Lenin used the ideas of Chernyshevsky, Nechaev, [etc.]...to inject a distinctly Russian dose of conspiratorial politics into a Marxist dialectic that would otherwise have remained passive - content to wait for the revolution to mature through the development of objective conditions rather than eager to bring it about through political action. It was not Marxism that made Lenin a revolutionary but Lenin who made Marxism revolutionary. ${ }^{382}$

381 Jonathan Sperber, Karl Marx, 404-407.

${ }^{382}$ Orlando Figes, A People's Tragedy: The Russian Revolution, 1891-1924 (New York: Penguin, 1998), 145, 146. 
While Marx himself, being a man of action, was occasionally susceptible to this "Leninist" way of thinking, the logic of his system does demand that one "wait" (though not passively) for conditions to mature rather than believe that skilled propagandizing, political maneuvering, and coalition-building alone can get the job done. Thus, just as the mature welfare state couldn't happen until things got worse - as they did with the Great Depression and World War II-so a transcending of capitalism can't happen until things get much worse than they are now. It is this that will induce people to come together, as it did eighty years ago, to effectually demand systemic changes.

Given that the centralized welfare state is becoming structurally untenable, ${ }^{383}$ what will necessarily evolve is an alternative economy. Exactly how this cooperative economy will interact with a decaying capitalism is impossible to predict-although it is already so interacting in places all over the world. Particularly in the early stages of the process, before they have established a myriad of supporting institutions, cooperatives and other anti-capitalist organizations will have to compromise some of their principles in order to compete successfully and survive in a hostile political and economic environment. But as the networks accumulate capital and experience, as well as grudging support from political and economic elites - as happened, too, during the transition from feudalism to capitalism (with regard to absolutism's support for capitalist industry) - they will acquire such power that they undermine the foundations of the current society. The world-order will come to consist of a mix of cooperative and competitive social relations such that it is no longer clear what is the "dominant" mode of production. Eventually this will change; cooperativism will continue "snowballing," propelled by its own momentum, as capitalism was in an earlier era. Just as worker co-ops' current rarity reinforces itself, so will their future growth reinforce itself. Throughout this history

${ }^{383}$ See Takis Fotopoulos, Towards an Inclusive Democracy: The Crisis of the Growth Economy and the Need for a New Liberatory Project (London: Cassell, 1997). 
the nation-state will be declining, in part because many of its functions will be taken over by other institutions. Whatever counterattacks there are from the elite will not be able to stop these processes; capitalism will have lost any competitive advantages over cooperativism, because the latter's efficiencies, which were in some ways ill-suited to a competitive, atomistic, profit-driven society, will finally be irresistible. It seems likely that even at the end of this process there will remain a role for the market and the pricemechanism - and even, in a minor capacity, for wage-labor, which will probably never be completely abolished everywhere in the world $^{384}$ — but precisely what that role will be is, again, impossible to say.

Prophecies are not necessary, however. What is necessary is only to embrace and institutionalize the attitude of people like Armando Robles and his fellow workers, Brendan Martin, Leah Fried, and the whole grassroots vanguard of the revolution. Militant action is what will birth a new world; abstract intellection, such as this book contains, will not. We need only remember the old truth, "The people united will never be defeated!" That is the pith of the Left's accumulated wisdom, and the guide to action.

\footnotetext{
${ }^{384}$ The world is a complex place, and different modes of production will always coexist. The capital/wage-labor relation will probably constitute for centuries a more-or-less large part of the world economy. But will it still be the dominant mode of production, the one that determines the dynamics of the whole system? As I have argued, there are good reasons to think the answer is no.
} 
